\title{
Goniatites Zone (middle Mississippian) ammonoids of the Antler Foreland Basin (Nevada, Utah)
}

\author{
DIETER KORN \& ALAN L. TITUS
}

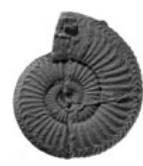

\begin{abstract}
The ammonoid faunas from the Goniatites Zone (Late Viséan; Mississippian) of the Camp Canyon Member (Chainman Formation) are described for the first time. The assemblage shows close relationships to time equivalent occurrences in Alaska and the American Midcontinent, but differs markedly from occurrences in Europe, North Africa, and the South Urals. Seven successive ammonoid biozones are proposed for this interval in North America, in ascending order: (1) Calygirtyoceras confusionense Ammonoid Biozone, (2) Calygirtyoceras arcticum Ammonoid Biozone, (3) Girtyoceras primum Ammonoid Biozone, (4) Girtyoceras gordoni Ammonoid Biozone, (5) Goniatites deceptus Ammonoid Biozone, (6) Goniatites eganensis Ammonoid Biozone, and (7) Goniatites multiliratus Ammonoid Biozone. The following ammonoid species are revised or newly described: Bollandoceras occidentale sp. nov., Entogonites burbankensis sp. nov., Entogonites borealis (Gordon, 1957), Entogonites acus sp. nov., Calygirtyoceras confusionense sp. nov., Calygirtyoceras arcticum Gordon, 1957, Girtyoceras primum sp. nov., Girtyoceras gordoni sp. nov., Girtyoceras hamiltonense sp. nov., Dimorphoceras worki sp. nov., Dimorphoceras rileyi sp. nov., Metadimorphoceras mangeri sp. nov., Metadimorphoceras richardsi sp. nov., Kazakhoceras bylundi sp. nov., Goniatites americanus Gordon, 1971, Goniatites deceptus sp. nov., Goniatites eganensis sp. nov., Goniatites sowerbyi sp. nov., and Praedaraelites loeblichi (Miller \& Furnish, 1940). Key words: Ammonoidea, Carboniferous, Mississippian, Viséan, Nevada, Utah, palaeobiogeography, biostratigraphy, Chainman Formation.
\end{abstract}

KoRn, D. \& TiTUS, A.L. 2011. Goniatites Zone (middle Mississippian) ammonoids of the Antler Foreland Basin (Nevada, Utah). Bulletin of Geosciences 86(1), 107-196 (60 figures, 37 tables, appendix). Czech Geological Survey, Prague. ISSN 1214-1119. Manuscript received November 8, 2010; accepted in revised form January 24, 2011; published online March 8, 2011; issued March 14, 2011.

Dieter Korn, Museum für Naturkunde, Leibniz Institute at the Humboldt University Berlin, Invalidenstraße 43, 10115 Berlin, Germany; dieter.korn@mfn-berlin.de•Alan L. Titus, Grand Staircase-Escalante National Monument, Kanab, Utah 84741; Alan_Titus@blm.gov

Goniatites de Haan, 1825 has the distinction of being one of the first named Carboniferous ammonoid genera. Even though many species formerly assigned to the genus are now referred to other genera like Arnsbergites, Lusitanoceras, Paraglyphioceras, and Dombarites (Korn 1988), it still has a 6 Ma chronostratigraphic range (Korn \& Kaufmann 2009) and a nearly global distribution. The genus ranges through a large part of the late Viséan (Asbian and early Brigantian equivalent) and has been reported from the European North Variscan basins such as the British Isles (e.g. Bisat 1924, 1934, 1952; Moore 1936, 1946, 1952, 1958; Hodson \& Moore 1959), the Rhenish Mountains (e.g. Brüning 1923; Schmidt 1925; Nicolaus 1963; Korn 1988, 1990, 1997a), the Ardennes (e.g. de Koninck 1880, Delépine 1940), the South Portuguese Zone (Korn 1997b, Korn \& Horn 1997), the Moroccan Meseta (Delépine 1941, Korn \& Ebbighausen 2008), South Variscan basins such as the Cantabrian Mountains (Kullmann 1961), the Anti-Atlas of Morocco (Korn et al. 2005, 2007; Klug et al. 2006), the South Urals (Bogoslovskaya 1966, Ruzhencev 1966), Novaya Zemlya (Kusina 1987, Kusina \& Yatskov 1999), Xinjiang (Liang \& Wang 1991), Alaska (Gordon 1957), and the United States Midcontinent (e.g. Girty 1909, 1911; Gordon 1962, 1965; Drahovzal 1972; Drahovzal \& Quinn 1972; Saunders et al. 1977). The stratigraphic occurrence of this distinctive taxon was even considered evolutionarily significant enough to warrant Ramsbottom \& Saunders (1985) to establish its range as a formal Early Carboniferous genus zone.

Goniatites also occurs in strata of North America's Antler Foreland Basin (Webster et al. 1984, Huh 1968), which extends over 2,500 km from Canada to south-eastern California (Fig. 1) and resulted from subsidence caused by the formation of the Antler Orogenic Highland in the Late Devonian and Mississippian (Eisbacher 1983). Antler Foreland Basin strata is Late Devonian to early Pennsylvanian in age and locally richly fossiliferous, with ammonoids occurring through most of the Early Carboniferous part of 

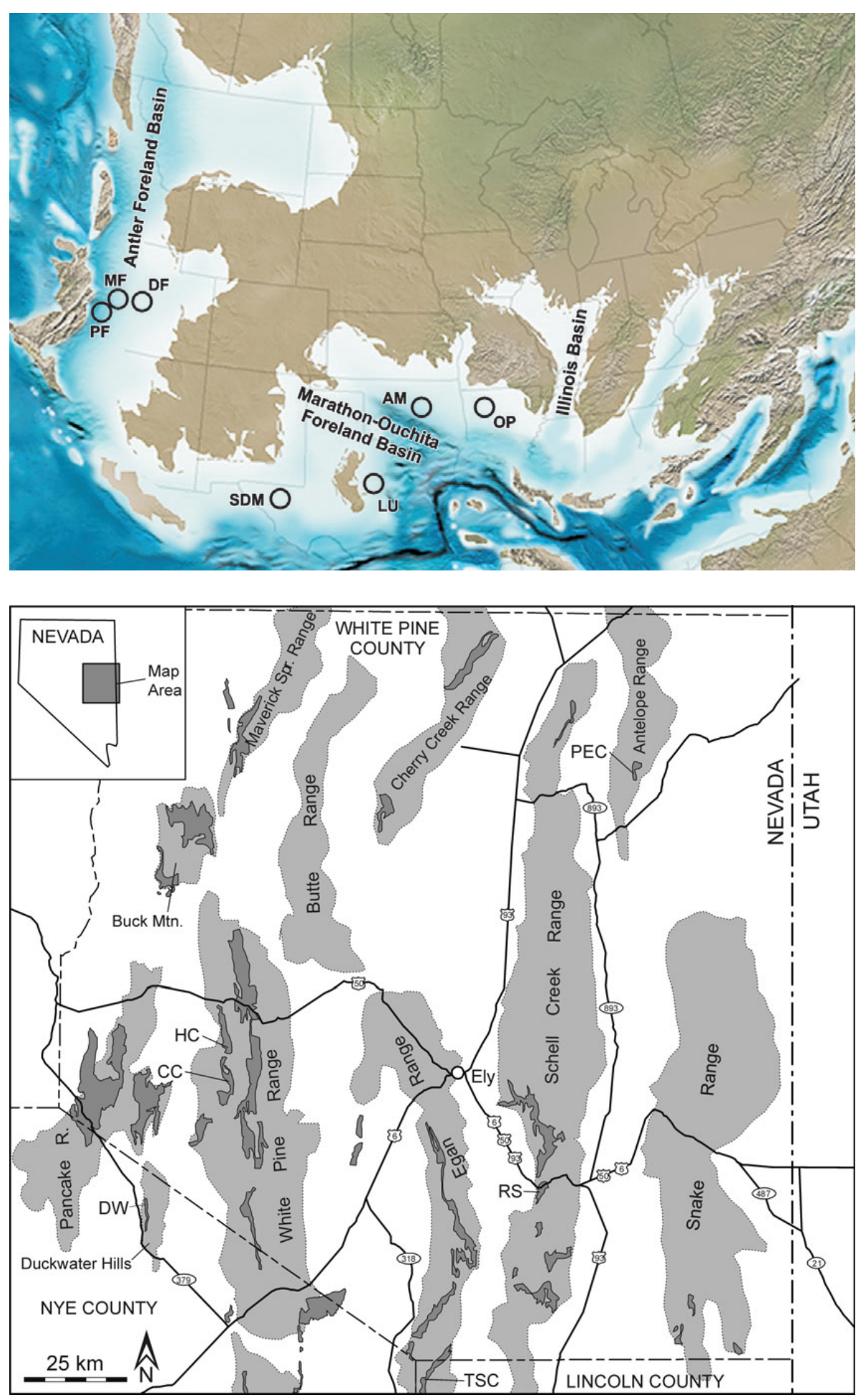

Figure 1. Palaeogeographic map of the eastern United States for the late Mississippian (modified after an image by Ron Blakey; http://jan.ucc.nau.edu/ rcb7/). Abbreviations: PF - Proximal Foredeep; MF - Medial Foredeep; DF - Distal Foredeep; SDM - Sierra Diablo Mountains; LU - Llano Uplift; AM - Arbuckle Mountains; OP - Ozark Plateau.

Figure 2. Map of east-central Nevada showing ammonoid localities. Abbreviations: DW - Duckwater Hills; CC Cathedral Canyon; HC - Hamilton Canyon; TSC - Trough Springs Canyon; RS - Rosebud Spring; PEC - Pony Express Canyon. Dark grey shading shows Mississippian outcrops. the sequence (Gordon et al. 1957; Gordon 1970, 1986; Webster et al. 1984; Petersen et al. 2000; Titus 2000; Work et al. 2000; Titus \& Manger 2001). Late Viséan (Asbian and Brigantian of the British stratigraphic scheme) ammonoids are particularly common in the shale and carbonate sequences of eastern Nevada and western Utah, and to a lesser extent of southern Idaho (Huh 1968). Surpris- ingly, the only previously published systematic treatments of Goniatites Zone (sensu Ramsbottom \& Saunders 1985) ammonoids from the Antler Foreland Basin are two brief studies of three taxa (Miller et al. 1949, Gordon 1971).

In 1992, ALT began measuring sections and collecting ammonoids from within the Antler Foreland Basin in eastern Nevada and western Utah (Figs 2, 3) for his dissertation 
Figure 3. Map of west-central Utah showing ammonoid localities. Abbreviations: NR - Needle Range; SBH - South Burbank Hills; JW - Jensen Wash; CMW - Conger Mountain West; CME Conger Mountain East; MC1-MC3 Middle Confusion Range 1-3; BSH Bishop Springs Dome; GM - Granite Mountain. Dark grey shading shows Mississippian outcrops.

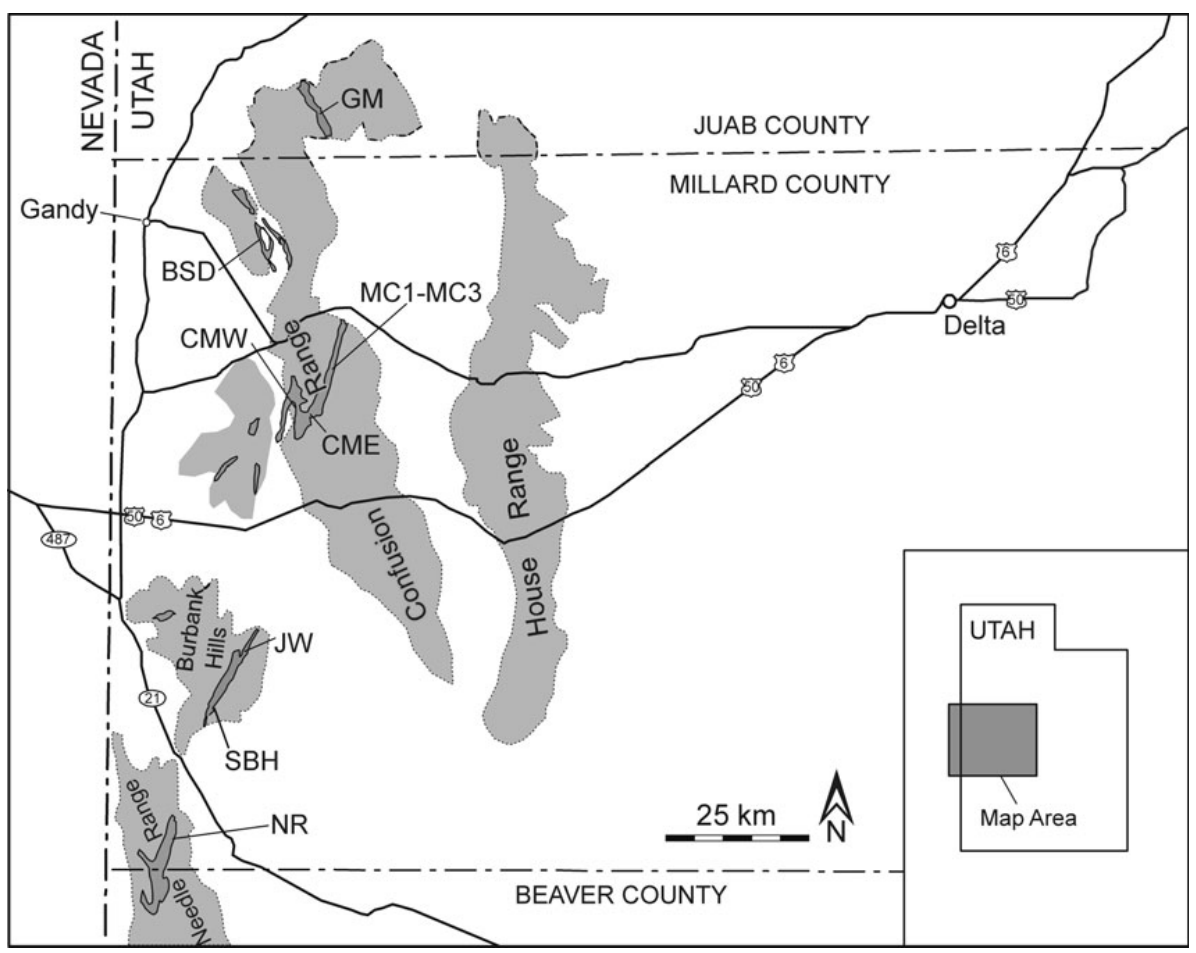

research. Only late early Serpukhovian (Arnsbergian Stage) material was treated systematically in this work (Titus 2000), but a large number of early Serpukhovian (Pendleian) and late Viséan ammonoid specimens were also assembled. The new material led ALT to the conclusion that the Antler Foreland Basin's Late Viséan ammonoid record was much more continuous, diverse and significant than reported in its most recently published review by Webster et al. (1984).

Over the course of the next 15 years, ALT continued to collect stratigraphically located Late Viséan ammonoid material from Nevada and Utah, which forms the bulk of this study. Subsequent collections made by ALT with the assistance of Nicholas J. Riley, Barry Richards, and DK have greatly refined the biostratigraphic resolution of the succession around the Asbian-Brigantian stage boundary and confirmed the region contains a remarkable, previously undocumented high-resolution record of the evolution of Goniatites and other contemporaneous ammonoid taxa. This systematic review of newly collected material establishes a high-resolution Asbian-early Brigantian ammonoid biostratigraphic zonation for the Antler Foreland Basin and documents ammonoid diversity for that time. Our work has also shown that recent advances in the phylogeny and biostratigraphy of Viséan ammonoids (Korn 1988, 1996), as well as our new data from the Antler Foreland Basin region, has necessitated restudy of even seemingly well-known North American assemblages.

\section{Previous work}

\section{Antler Foreland Basin}

Inexplicably, nearly all material in early collections from the study area is Serpukhovian in age (e.g. Hall \& Whitfield 1877; Miller \& Furnish 1940; Youngquist 1949a, 1949b). The region's first description of ammonoids from the Goniatites Zone was by Miller et al. (1949; plate 99, figs 7-10), who illustrated specimens of Goniatites and Girtyoceras collected from the White Pine Range area of east-central Nevada. We could not relocate the locality, and the specimens are immature, but we can still make confident species level assignments: 'Goniatites choctawensis Shumard, 1863' (= Goniatites eganensis sp. nov.), 'Girtyoceras aff. G. meslerianum (Girty, 1909)' (= Girtyoceras hamiltonense sp. nov.).

The first substantial collections of Asbian and early Brigantian ammonoids from the region were made in the late 1950 s by mapping teams from the United States Geological Survey working in west-central Utah. Although biostratigraphic analyses of these collections were made by Mackenzie Gordon Jr. (Gordon et al. 1957, Gordon 1970, Webster et al. 1984), most of this material has only been reported through faunal lists. The single systematic paper that resulted from these collections (Gordon 1971) named Goniatites americanus using specimens collected at Granite Mountain, Juab County, Utah as the primary types. The most recent published work on these assemblages 
(Webster et al. 1984) lists, in ascending order, the following taxa (with our revisions):

Goniatites americanus Zone: 'Goniatites americanus Gordon, 1971' (= Goniatites americanus Gordon, 1971), 'Girtyoceras arcticum Gordon, 1957' [= Calygirtyoceras arcticum (Gordon, 1957)], 'Girtyoceras n. sp. A' (= Girtyoceras primum sp. nov.), 'Entogonites borealis Gordon, 1957' [= Entogonites borealis Gordon, 1957 (part)], 'Dimorphoceras n. sp.' (= Dimorphoceras sp.), 'Prolecanites sp.' (= ? Praedaraelites sp.).

Goniatites multiliratus Zone: 'Goniatites multiliratus Gordon, 1962' (= Goniatites deceptus sp. nov.), 'Girtyoceras meslerianum (Girty, 1909)’ (= Girtyoceras hamiltonense sp. nov.).

Unfortunately, Mackenzie Gordon Jr. died in 1992 before he was able to publish an intended monographic treatment of this material.

Walter Sadlick (1960, 1965, 1995) also published ammonoid species lists that include Viséan taxa (with identifications made by Mackenzie Gordon Jr.) based on material he collected during his dissertation research on Chainman stratigraphy. This author reports the following Asbian-early Brigantian taxa in his dissertation:

'Goniatites crenistria Zone (equals G. americanus Zone of Webster et al. 1984): 'Goniatites crenistria Phillips, 1836' (= Goniatites americanus Gordon, 1971), 'Girtyoceras sp.' [= Calygirtyoceras arcticum (Gordon, 1957)].

Goniatites multiliratus Zone: 'Goniatites multiliratus Gordon, 1962' (= Goniatites deceptus sp. nov.).

Huh (1968) reported that abundant, but poorly preserved Goniatites occur in the Scott Peak Formation, north of the Snake River Plain in Idaho. This is one of the only other areas in the Antler Foreland Basin known to yield three-dimensional Goniatites Zone ammonoids outside of Nevada and Utah. However, this material remains unpublished and we have not personally examined specimens from the locality.

\section{Northern Alaska/North-western Canada}

Late Viséan ammonoids were first reported from Alaska by Gordon (1957). In this important paper, several new taxa were named from collections made in the eastern DeLong Mountains, Ipnavik River Basin, Etivluk River Basin, Kiruktagiak River Basin, and Anaktuvuk River Basin areas from the Black Shale Member of the Alapah Limestone, now assigned to the Kuna Formation (Mull et al. 1982). The most extensive and important collections are from the Kiruktagiak River Basin localities from which the types of Dimorphoceras algens Gordon 1957, Girtyoceras arcticum Gordon 1957, and Entogonites borealis Gordon 1957 were obtained. In summary, Gordon (1957) listed seven taxa from the Kuna Formation that we consider contemporaneous with the assemblages in this study: 'Bollandites bowsheri Gordon, 1957' (= Bollandites bowsheri Gordon, 1957), 'Beyrichoceras micronotum (Phillips, 1836)' [= Bollandoceras cf. micronotum (Phillips, 1836)], 'Goniatites crenistria Phillips, 1836' (= Goniatites americanus Gordon, 1971), 'Girtyoceras arcticum Gordon, 1957' [= Calygirtyoceras arcticum (Gordon, 1957)], 'Girtyoceras endicottense Gordon, 1957' (= Girtyoceras endicottense Gordon, 1957), 'Dimorphoceras algens Gordon, 1957' (=Dimorphoceras algens Gordon, 1957), 'Entogonites borealis Gordon, 1957' (= Entogonites borealis Gordon, 1957).

Two other taxa named in that paper, Sudeticeras alaskae Gordon, 1957 (actually Wiedeyoceras sp.) and Eothalassoceras aurorale Gordon, 1957 (actually Eothalassoceras inexpectans Miller \& Owen, 1937), are based on Pennsylvanian specimens from the Seminole Formation of eastern Oklahoma that were erroneously mixed with the Alaskan Viséan material (Gordon 1965). It is important to note that all of the material from the Kiruktagiak locality including the type specimens was collected without regard to precise stratigraphic control and came from a 13 metres thick interval of concretionary shale. Given the mix of morphologies in the type suites for Entogonites borealis and Calygirtyoceras arcticum, as well as their association with true Girtyoceras (G. endicottense), we believe most of these taxa are probably based on stratigraphically mixed samples coming from at least two distinct Asbian zones. Additional sampling is needed before this issue can be resolved.

Sellers \& Furnish (1960) described specimens of Goniatites crenistria Phillips, 1836, collected from the headwaters area of the Peel River, Yukon (north-western Canada), from an unnamed dark silty shale unit that is probably correlative with the Kuna Formation. The specimens possess distinctive $\mathrm{V}$-shaped ventral lobes with shallow medial saddles and crenistriate ornament and we tentatively refer them to Goniatites americanus Gordon 1971, of Asbian (early Chesterian) age.

\section{Illinois Basin}

Asbian ammonoids have long been known to occur on the western and north-eastern margin of the Illinois Basin (Collinson 1955, Knapp 1965). A single specimen collected from the Monroe, Illinois area served as the holotype for Goniatites monroensis (Worthen, 1890), which was later, redescribed by Collinson (1955) and referred to Prolecanites. The west side of Greencastle, Indiana also yields an abundant, well-preserved Goniatites Zone ammonoid fauna (Miller \& Gurley 1896), from which they named the species Goniatites greencastlensis. Collinson (1955) 
further clarified that the widely separated Monroe and Greencastle localities are both in the basal beds of the Ste. Genevieve Formation (earliest Chesterian) and contain essentially the same assemblage. Knapp (1965) reviewed the Greencastle assemblage, added Bollandites phillipsi (Bisat, 1934) and Prolecanites serpentinus (Phillips, 1836) to the species list, and concluded that Goniatites greencastlensis, owing to its widely umbilicate juvenile stage and narrow ventral lobe of the suture, doesn't belong in Goniatites. We currently see no reason why Goniatites greencastlensis Miller \& Gurley, 1896 should not be referred to the genus Bollandites, even though it is one of the widest shelled species in the generic complex.

Recent collecting at this locality by David M. Work and ALT has secured the previously reported Bollandites greencastlensis (Miller \& Gurley, 1896), Bollandites phillipsi (Bisat, 1934) and Prolecanites americanus Miller \& Garner, 1953 (P. serpentinus of Knapp 1965), along with a crenistriate variety of Goniatites (cf. G. americanus Gordon, 1971) and primitive Kazakhoceras that are the earliest known records for the latter genus in the world. While there are no taxa in common with those found in Asbian strata of the Antler Foreland Basin or northern Alaska, the overall character of the assemblage demonstrates it is Asbian $\left(\mathrm{B}_{1}\right)$ and roughly equivalent to, or more probably, slightly older than the earliest Asbian ammonoids found in Utah and eastern Nevada.

\section{Marathon-Ouachita Foreland Basin}

From our analysis of both published and unpublished data, Asbian ammonoids have not yet been collected from the southern midcontinental United States. This region's record appears to begin in the upper portion of the early Brigantian and continues almost unbroken through the early Serpukhovian (Saunders et al. 1977, Gordon 1965). Four principle areas, all within the general Marathon-Ouachita Foreland Basin trend, have produced nearly all of the known Goniatites Zone specimens. From west to east, these are; (1) the Sierra Diablo Mountains (west Texas), (2) the Llano Plateau (central Texas), (3) the Arbuckle Mountains (south central Oklahoma), and (4) the eastern Ozark Plateau (Batesville area of north-eastern Arkansas), each to be discussed separately below. All the ammonoid bearing concretionary black shale units are located on the northern side of the foreland basin, bordering the continental shelf (Gordon 1965, 1970; Saunders et al. 1977).

Sierra Diablo Mountains. - No systematic analysis of Viséan ammonoids from the Sierra Diablo Mountains has ever been published. However, King (1965) listed eight Viséan species from the Barnett Formation; 'Goniatites crenistria Phillips, 1836', 'Goniatites choctawensis Shumard,
1863', 'Goniatites sp.', “Girtyoceras sp. cf. G. meslerianum (Girty, 1909)', 'Neoglyphioceras cloudi (Miller \& Youngquist, 1948)', 'Neoglyphioceras sp.', and 'Lyrogoniatites sp. cf. L. newsomi (Smith, 1903)' based on collections made by J.B. Knight, A.K. Miller, and W.M. Furnish in the 1930s and 1940s at the Figure 2 Ranch. Even though we have not examined them, we believe these collections are stratigraphically mixed, with Goniatites "crenistria" and Girtyoceras sp. cf. G. meslerianum coming from the upper portion of the Goniatites Zone and the remainder from higher in the section. There is only one known locality that produces prolific Brigantian ammonoid material at the Figure 2 Ranch and this was revisited in 2000 by ALT. Based on these collections, King's Goniatites crenistria Phillips, 1836 is probably G. eganensis sp. nov. and Girtyoceras sp. cf. G. meslerianum (Girty, 1909) is Girtyoceras welleri Gordon, 1965.

Llano Uplift. - Barnett Shale outcrops in the Llano Uplift of central Texas contain a rich and abundant ammonoid fauna, much of which has been previously documented (Gabb 1862, Plummer \& Scott 1937, Miller \& Youngquist 1948, Titus 1999). All published specimens from this region are late Brigantian or Serpukhovian in age. However, collecting by ALT at the famous Chappel Hill quarry locality near San Saba in the fall of 2007 confirmed that Goniatites multiliratus Gordon, 1962 and Girtyoceras meslerianum (Girty, 1909) occur in tan-coloured, punky concretions about 1 metre above the base of the Barnett, which appears to be the oldest Mississippian ammonoid fauna in the region.

Arbuckle Mountains (Oklahoma). - Early Brigantian ammonoids are very common in the Caney Formation of the Arbuckle Mountains area, south Central Oklahoma (Gordon 1970). The first description of this fauna was made over 100 years ago (Girty 1909). In that paper, the following species were listed (with our revisions) from several localities: 'Goniatites choctawensis Shumard, 1863' [= Goniatites multiliratus Gordon, 1962 (part)], 'Goniatites newsomi Smith, 1903' [= Pachylyroceras newsomi (Smith, 1903)], 'Adelphoceras meslerianum Girty, 1909' [= Girtyoceras meslerianum (Girty, 1909)], 'Gastrioceras caneyaum Girty, 1909' [= Neoglyphioceras caneyaum (Girty, 1909)], 'Trizonoceras lepidum Girty, 1909' (= Trizonoceras lepidum Girty, 1909).

Following the designation of a neotype for Goniatites choctawensis Shumard, 1863 (now referred to Dombarites) by Branson et al. (1959), Gordon (1962, 1965) postulated that the material described by Girty (1909) came from at least two different stratigraphic horizons; a lower one containing a more finely ornamented species for which he erected the name Goniatites multiliratus, and an upper one bearing "Goniatites" choctawensis Shumard. He further 
stated that $G$. multiliratus and the co-occurring Girtyoceras meslerianum (Girty, 1909) were only present at Girty's stations 2081 and 2083. Because our own fieldwork has demonstrated that a relatively complete late early and late Brigantian ammonoid record exists in the Caney Formation, we concur with Gordon and come to the conclusion that Goniatites multiliratus Gordon, 1962 and Girtyoceras meslerianum (Girty, 1909) are the only Goniatites Zone ammonoids actually figured by Girty.

Miller \& Furnish (1940) erected Epicanites loeblichi based on material from the Caney Formation collected south of Ada, Pontotoc County, Oklahoma. According to Gordon (1965), these specimens were secured from the Goniatites multiliratus interval of the Deleware Creek Member and therefore are from the upper portion of the Goniatites interval. Additional specimens of Girtyoceras meslerianum (Girty, 1909) from the Wapanucka area of Oklahoma were also described and illustrated by McCaleb et al. (1964). Drahovzal (1972) reviewed Goniatites Zone assemblages from Oklahoma, listing only Goniatites multiliratus Gordon, 1962 and Girtyoceras meslerianum (Girty, 1909). Thus, three taxa have been described from the upper portion of the Goniatites Zone in the Deleware Creek Member of the Caney Formation: Epicanites loeblichi Miller \& Youngquist, 1940, Goniatites multiliratus Gordon, 1962, and Girtyoceras meslerianum (Girty, 1909).

Eastern Ozark Plateau (Arkansas). - Starting with Smith (1903), which is among the earliest reports of an ammonoid from the Goniatites Zone in North America, a number of authors (e.g. Girty 1911; Gordon 1965, 1970) have referred specimens collected from the lower portion of the Moorefield Formation in the Batesville area (fide Gordon $1965)$ to Goniatites crenistria Phillips, 1836. However, the wide lobes and deep ventral saddles in the sutures of these specimens preclude them from that taxon. Smith (1903) also described and illustrated specimens of Girtyoceras collected from lower Moorefield Formation beds associated with " $G$. crenistria" that were erroneously referred to the nomen dubium "Glyphioceras calyx (Phillips, 1836)". This material was redescribed and re-illustrated by Gordon (1965) who referred the Goniatites specimens to $G$. aff. crenistria Phillips, 1836 and erected a new species of Girtyoceras, G. welleri Gordon 1965, for the specimens referred to Glyphioceras calyx. In that same work, Gordon (1965) also illustrated and described crushed specimens of Goniatites multiliratus Gordon, 1962 from slightly higher stratigraphically than the horizon yielding the crenistriate forms. Drahovzal (1972) reviewed the Goniatites Zone assemblages of Arkansas and reiterated the same conclusions as Gordon (1965). In summary, the following forms, with our revisions, have been reported from the Goniatites Zone of Arkansas by Gordon (1965).
Lower Moorefield Formation: 'Goniatites aff. G. crenistria Phillips, 1836' (= Goniatites eganensis sp. nov.), 'Girtyoceras welleri Gordon, 1965' (= Girtyoceras welleri Gordon, 1965).

Upper Moorefield Formation: 'Goniatites multiliratus Gordon, 1962' (= Goniatites multiliratus Gordon, 1962).

\section{Present study and stratigraphic background}

\section{Antler Foreland Basin}

All of the Nevada and Utah material described in this study was assembled from 94 field collections (Appendix B) made at 18 general localities in east-central Nevada and west-central Utah (Figs 2, 3). Most specimens were collected from the Concretionary Phosphatic Shale Member of the Chainman Formation of Poole \& Sandberg (1991), which was subsequently referred to the lower portion of the Camp Canyon Member (Sadlick 1995). In its type area, the Camp Canyon Member rests conformably on the Skunk Spring Member and is conformably overlain by the Willow Gap Member (Fig. 4). Camp Canyon lithologies are primarily dark grey or black coloured fissile or non-fissile shale and grey or tan weathering siltstone. Subordinate amounts of sandstone, nodular and granular phosphate, and bedded or concretionary micritic carbonate occur locally. In general, good exposures of the Camp Canyon Member are uncommon.

The Camp Canyon Member can be recognized consistently over eastern Nevada and west-central Utah, however the overall thickness, lithology, and age varies widely, depending on position relative to the ancient Antler Highland (Fig. 4). Despite this complexity, three primary facies belts can be recognized within the Viséan age portion of the Camp Canyon Member. From west to east these are: (1) a proximal foredeep sequence of greater thickness (exceeding 500 metres) and a marked presence of siderite concretions and sandstone; (2) a medial foredeep sequence characterized by condensed sequences, an abundance of siltstone and nodular and granular phosphate, and general lack of siderite and sandstone; (3) a distal foredeep/lower carbonate ramp facies characterized by sediments from eastern sources, abundant nodular and granular phosphate, siltstone, and the presence of lower (distal) ramp facies fine-grained carbonate beds. The Viséan-early Serpukhovian interval in the Chainman Formation is essentially conformable through most of the study area, but may exhibit highly condensed intervals with few or no body fossils due to sediment starved depositional systems, particularly in central and eastern White Pine County, Nevada. We see no compelling biostratigraphic or stratigraphic evidence in the study area for the widespread lower Chesterian (early Brigantian) regional angular unconformity hypothe- 
Figure 4. Facies scheme for the Chainman Formation in the Antler Foreland Basin. Abbreviations: DW - Duckwater Hills; CC - Cathedral Canyon; HC - Hamilton Canyon; TSC - Trough Springs Canyon; RS - Rosebud Spring; JW - Jensen Wash; SB - South Burbank Hills; NR - Needle Range; GM - Granite Mountain; MC - Middle Confusion Range; LS - limestone; while ellipses limestone concretions; black ellipses siderite concretions.

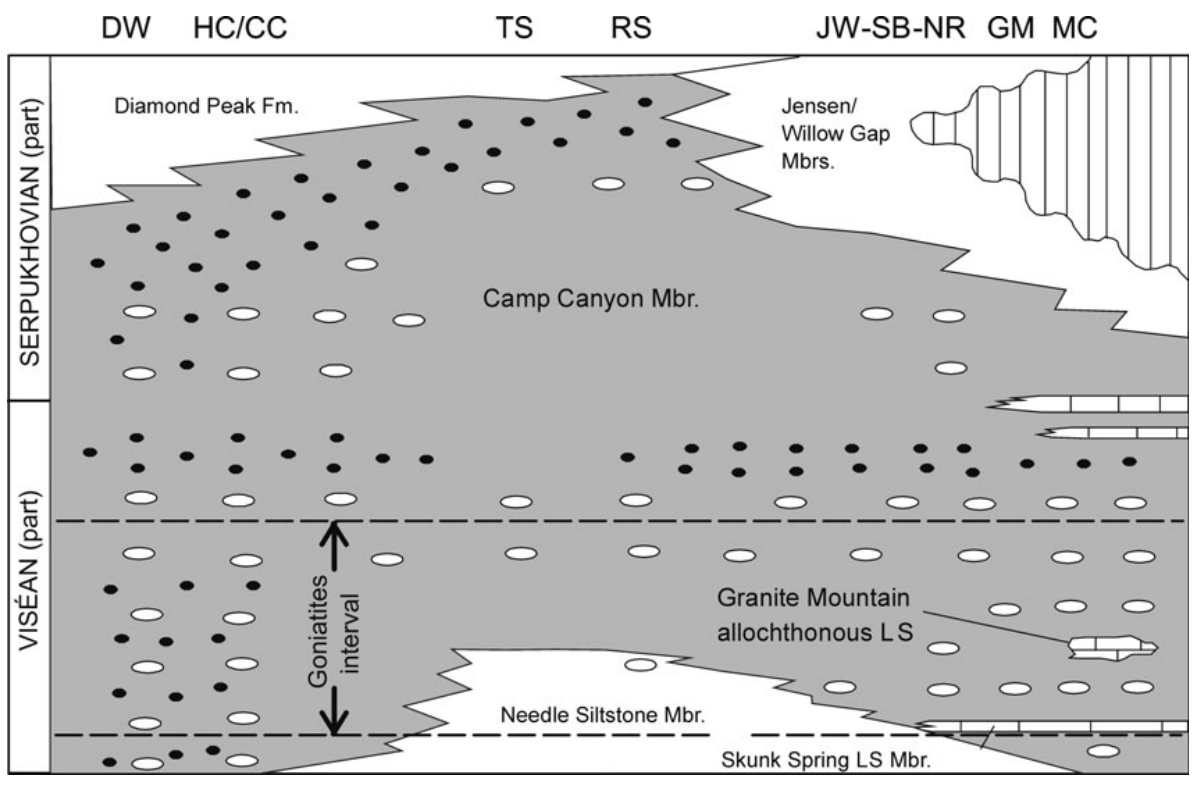

sized by Trexler et al. (1995) at the base of their Newark Canyon Sequence. Available evidence possibly points to an earlier forebulge migration driven unconformity that had already reached western Utah by middle Meramecian time (Sandberg et al. 2008).

\section{Proximal Foredeep}

Duckwater Hills. - Ammonoids were reported by Youngquist (1949a) from the Duckwater Hills locality in Nye County (Fig. 2) where the Camp Canyon Member is well exposed in a broad, north-south trending strike valley bounded on the west by the Devonian Devils Gate and Joana formations and to the east by Neogene volcanic units (Kleinhampl \& Ziony 1985). All of Youngquist's reported material from this locality is Pendleian (early Serpukhovian) in age. In 1993, ALT discovered that the section is relatively continuous (Fig. 5), well-exposed, and produces ammonoids well down into the late Viséan. Both early and late Brigantian ammonoids are common. Threedimensionally preserved early Brigantian material was found in two prominent septarian concretion horizons that occur about 48 metres below the Viséan-Serpukhovian boundary or 78 metres below the top of the exposed section, which ends in late Pendleian strata. The lower septarian horizon (bed 4) is locally packed with specimens of Goniatites deceptus sp. nov. and rare Girtyoceras hamiltonense sp. nov. Although many specimens exhibit septarian disruption, overall the material is excellently preserved. A total of three collections were made from this horizon (93NVNY-1, 07NVNY-2, 07NVNY-4). The upper horizon (bed 9), which is approximately 1.5 metres higher and above a bright orange sandstone unit, contains rare speci- mens of Goniatites eganensis sp. nov. and Goniatites sowerbyi sp. nov. (10NVNY-1).

Hamilton Canyon. - The Chainman Formation is at least 750 metres thick in the White Pine Range of western White Pine County, Nevada. Surface outcrops are extensive (Humphrey 1960, Hose \& Blake 1976), but good exposures are rare, generally being limited to recently eroded arroyos and canyons. Exposures yielding Viséan ammonoids appear to be concentrated on the west side of the range between Cathedral Canyon and the north end of Hamilton Canyon (Fig. 2), however we did not exhaustively survey the region and there is tremendous unexplored potential, especially north of Highway 50. The Goniatites Zone interval is at least 200 metres thick but so far we recognize only three horizons, all of which are in the upper part. Late Brigantian, early, middle, and late Pendleian, and middle Arnsbergian ammonoids are also common in the area. The best exposures of Goniatites Zone strata are in a series of west-northwest trending drainages north of the abandoned town of Hamilton (Fig. 5) where four collections (95NVWP-15, 95NVWP-17, 07NVWP-3) were made from a horizon of grey and orange brown weathering concretions (bed 44). This horizon has a relatively diverse assemblage dominated by Goniatites eganensis sp. nov. and Girtyoceras hamiltonense sp. nov., but also containing Praedaraelites loeblichi (Miller \& Furnish, 1940), and Metadimorphoceras richardsi sp. nov. Measured sections indicate this horizon is at least 190 metres above the base of the Chainman Formation.

Eberhardt Mill (Cathedral Canyon or Shermantown Canyon). - Large areas mapped as Chainman Formation occur not far south of the Hamilton Canyon area, just east of 


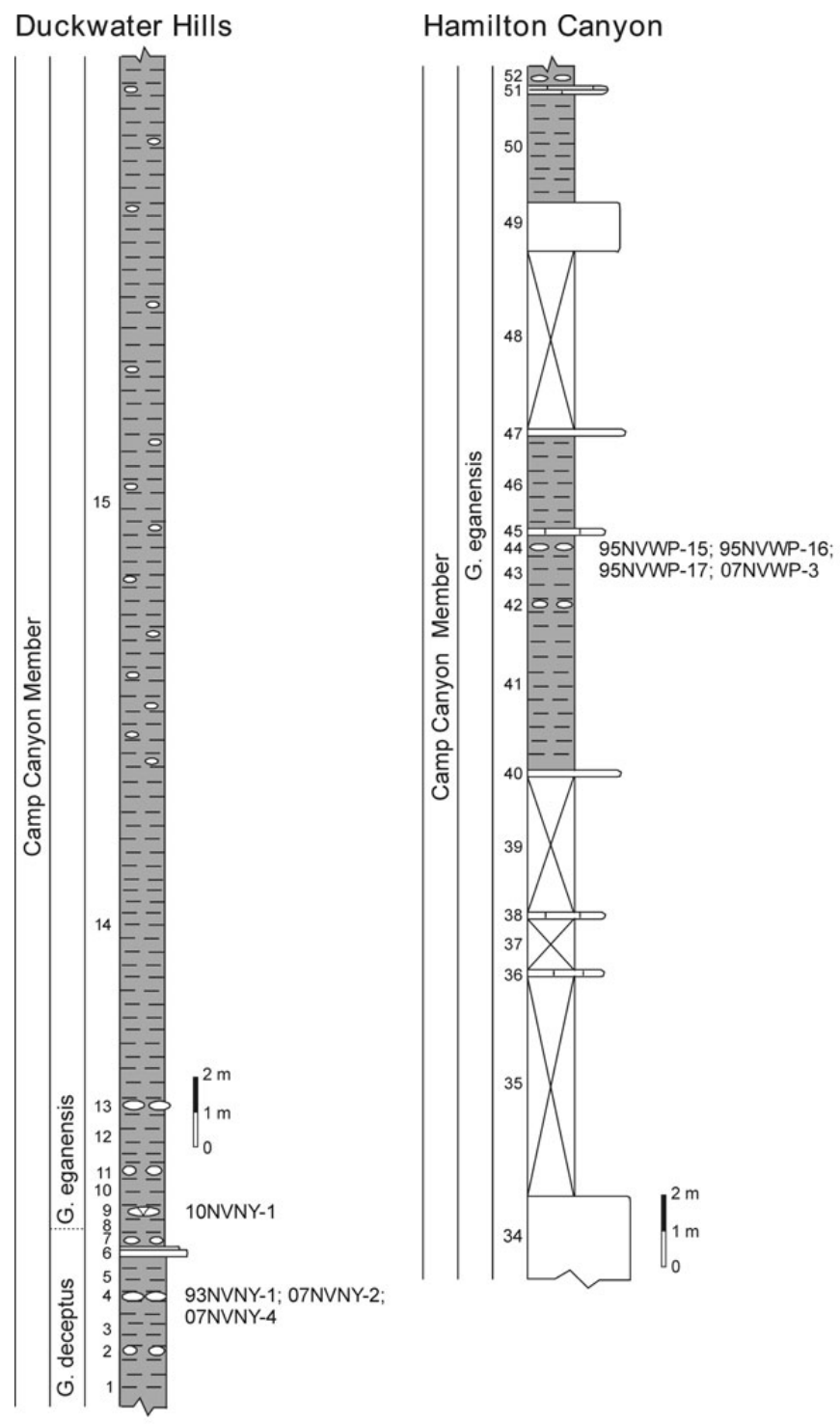

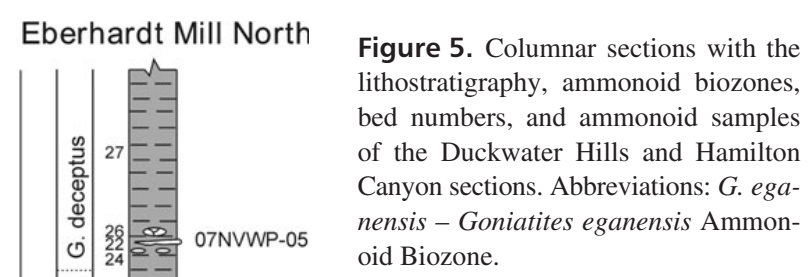

the mouth of Shermantown Canyon (Humphrey 1960). However, until recent erosion triggered by fire denudation in 2006-2007, the exposures were generally poor. The fires and erosion have temporarily created excellent exposures of Chainman Formation just south of the classic Eberhardt Mill site in the White Pine Mountains (Fig. 2). In 2007 DK and ALT secured numerous specimens of beautifully preserved Goniatites deceptus sp. nov. and rare Girtyoceras hamiltonense sp. nov. (07NVWP-5) from concretionary lenses packed with leiorhynchid brachiopods and cephalopods that occur approximately $80 \mathrm{~m}$ above the base of the exposed section. A second, lower horizon of dark grey concretions occurs approximately 20 metres below the
G. deceptus horizon from which were secured a few nondiagnostic fragments of Girtyoceras. Goniatites eganensis assemblage taxa were not found at this locality but presumably occur upsection as at the Duckwater Hills (see above).

\section{Medial Foredeep}

Trough Springs Canyon. - The south-eastern side of the southern Egan Range has a broad north-northeast trending strike valley formed in east dipping beds of the Chainman Formation and Scotty Wash formations (Tschanz \& 
Figure 6. Columnar sections with the lithostratigraphy, ammonoid biozones, bed numbers, and ammonoid samples of the Trough Springs Canyon, Rosebud Spring, and Pony Express Canyon sections. Abbreviations: $\mathrm{N}$ - Needle Member; Sk - Skunk Spring Member; G. eganensis - Goniatites eganensis Ammonoid Biozone; C. arcticum Calygirtyoceras arcticum Ammonoid Biozone.

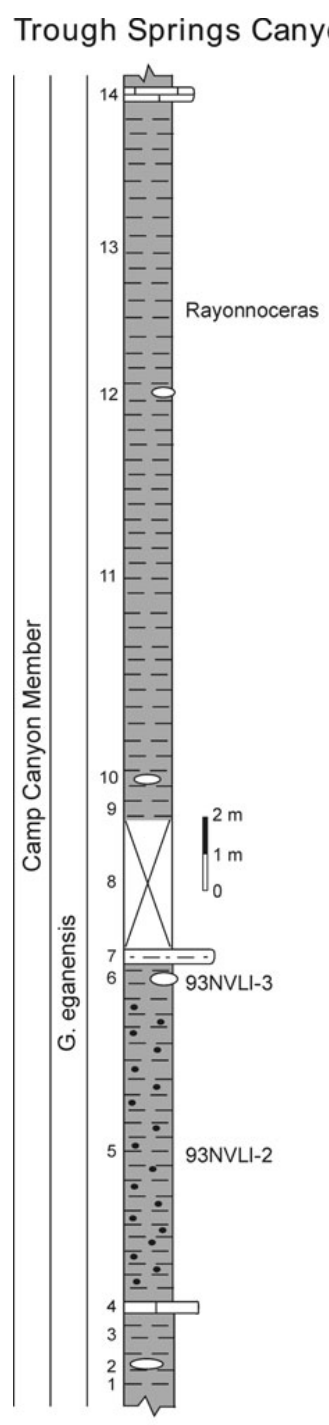

Pampeyan 1970). Unfortunately, the Camp Canyon Member is well exposed in only one area, just north of where the Trough Springs Canyon road forks north and south into the strike valley (Fig. 2). This section is interpreted, along with those at Rosebud Spring and Pony Express Canyon, as having been deposited in some of the deepest-water, most-offshore settings in the study area (Fig. 6). Although early Serpukhovian ammonoids are abundant, Viséan ammonoids are not common, probably as a function of corrosion, corrasion, bioerosion, and early diagenetic removal of aragonite shells rather than an ecological or physical barrier to the presence of living animals in the water column. Low oxygen levels near the sediment-water interface are also indicated by a general lack of shelly benthos in concretions and on shale bedding surfaces. A single non-septarian concretionary horizon (bed 6) packed with the remains of ammonoids (Goniatites eganensis sp. nov. and Goniatites sowerbyi sp. nov.), gastropods, bivalves, and leiorhynchid brachiopods did produce a large collec-

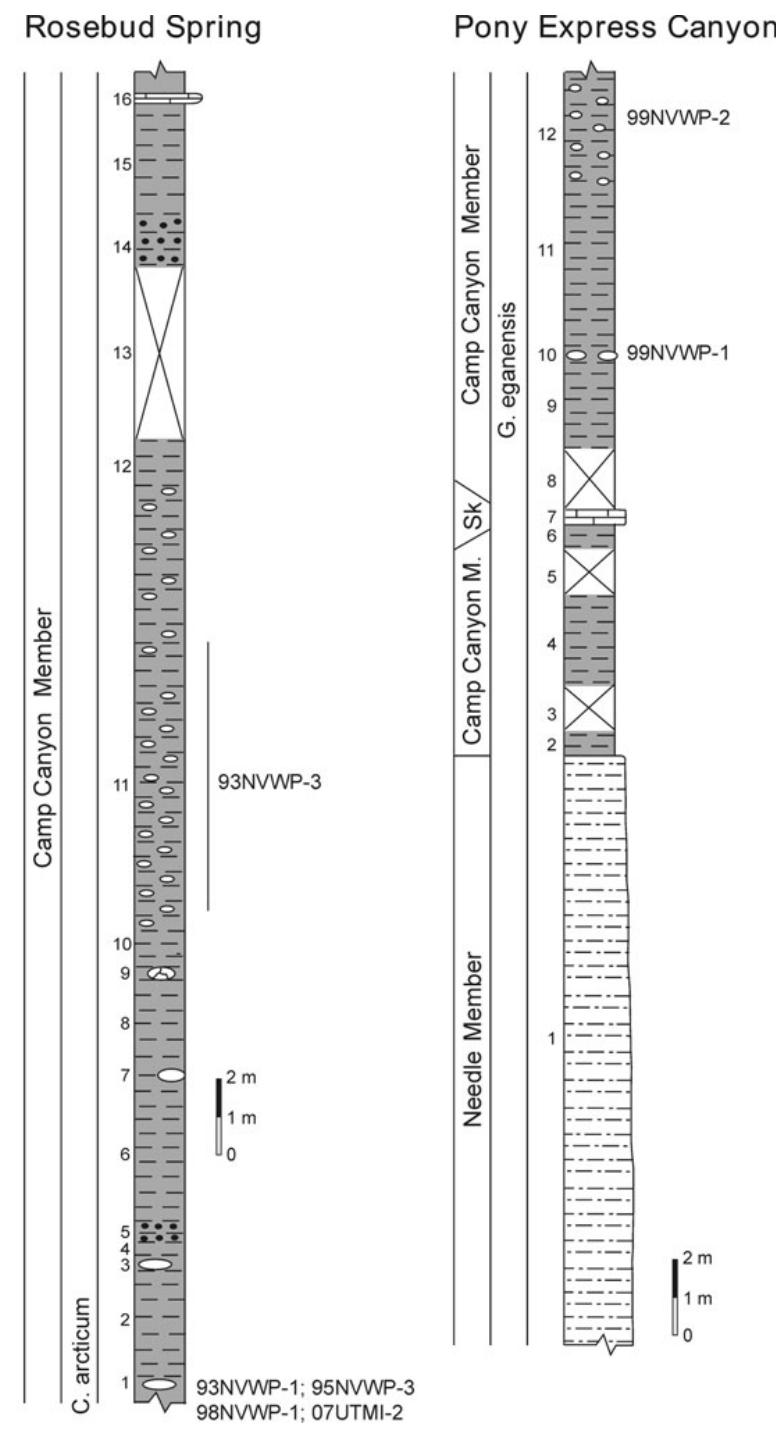

tion (93NVLI-3). The presence of benthic elements at this horizon, which correlates with a similar occurrence of benthic fauna at the Pony Express Canyon locality, indicates that conditions even in this portion of the basin did briefly become only mildly disaerobic in the early Brigantian. Most Brigantian concretions at Trough Springs have a grey to tan punky appearance, and are partly "de-calcified" with most specimens occurring as yellow-orange coloured limonitic steinkerns and replacements that crumble easily during collection. Although this diagenetic alteration destroyed the quality of many specimens, some individuals are excellently preserved. A single uncrushed specimen of Goniatites eganensis was also collected from bed 5 about four metres below 93NVLI-3 in a 25 millimetre diameter phosphate concretion (93NVLI-2). Crushed lirate Goniatites cf. G. deceptus sp. nov., also occur in a poorly exposed tangrey septarian concretionary horizon (bed 2) around nine metres below 93NVLI-3. The material from bed 2 is poorly preserved and no collection was made. 
Rosebud Spring. - Carboniferous ammonoids have long been known from this general area (Fig. 2), which was referred to as the Connor's Pass locality by Youngquist (1949a). Because Connor's Pass (or Connor's Summit) is actually located several kilometres to the east of the locality, we have renamed it after the nearest physiographic feature, Rosebud Spring. The structural geology of this part of the Schell Creek Range is complex (Hose \& Blake 1976) and intact, exposed sections of the Camp Canyon Member are rare. However, at Rosebud Spring, a moderately north-dipping section appears to be relatively intact from at least the Asbian through the early Serpukhovian. As at Duckwater, all previously published material from Rosebud Spring is early Serpukhovian (Pendleian) in age. In 1993, ALT found the Rosebud Spring Camp Canyon Member section also yields Asbian and late Brigantian ammonoids. The lowest known Viséan ammonoid bearing horizon is a row of mostly non-septarian, medium-grey weathering $0.75 \mathrm{~m}$ diameter concretions (bed 1) exposed on the east side of the Rosebud Spring drainage (Fig. 6). A few specimens of Goniatites americanus Gordon, Calygirtyoceras arcticum Gordon, Entogonites sp., and Kazakhoceras bylundi sp. nov. were secured in four separate collections (93NVWP-1, 95NVWP-3, 98NVWP-1, 07NVWP-2). A prominent horizon of orange-tinted large septarian concretions (bed 9) that we correlate with similar concretions in the upper portion of the early Brigantian at localities both to the east and west, occurs about 8 metres upsection. No diagnostic material was collected from this horizon, but distinctive late Brigantian ammonoids such as Pachylyroceras and Lusitanoceras occur within fifteen metres upsection (sample 93NVWP-3) suggesting the septarian interval is late early Brigantian in age and that the section is highly condensed because of sediment starvation.

Pony Express Canyon. - Good outcrops of Chainman Formation are uncommon in the Antelope Range, located north-east of Ely. However, relatively good exposures of the Needle and Camp Canyon members and the underlying Joana Limestone do occur in the vicinity of Pony Express Canyon (Hose \& Blake 1976), on the east side of the range (Fig. 2). Numerous crenistriate Goniatites eganensis sp. nov. and rare Girtyoceras hamiltonense sp. nov. (99NVWP-1) associated with the brachiopod Leiorhynchus sp. were collected by ALT from a single horizon of highly fossiliferous concretions (bed 10) that occur about 3.7 metres above what is believed to be the Skunk Spring Member (Fig. 6). Three metres above this lower ammonoid bearing horizon are small maroon-to-brown-weathering siderite concretions bearing uncommon late Brigantian ammonoids such as Pachylyroceras (99NVWP-2), indicating the section, in similar fashion to that at Rosebud Spring, has a highly condensed Asbian-early Brigantian interval, probably due to distance from sediment sources.

\section{Distal Foredeep/Shelf Margin}

Battleship Wash. - Lirate Goniatites occur abundantly in a packstone carbonate within the middle portion of the Battleship Wash Formation at and around the type section in Battleship Wash, Clark County, Nevada. They are just below a major sequence boundary marked by a disconformity and terra rossa, which may explain their apparent absence just to the north at the Mid-Carboniferous Global Stratotype Section and Point in Arrow Canyon. The specimens are poorly preserved, coarsely re-crystallized calcite shells that bond very tightly to both external moulds and steinkerns. A protracted collecting effort (04NVCL-1) by ALT in the company of Barry Richards, who brought the occurrence to the attention of the former, yielded only a single diagnosable fragment showing traces of pronounced lirate ornament. The strength and density of the lirae suggests the Battleship Wash taxon is either Goniatites deceptus sp. nov. or Goniatites multiliratus Gordon, 1962. Pendleian ammonoids also occur in the upper portion of the Battleship Wash Formation at its type section, demonstrating it is comprised almost entirely of early Brigantian and early Pendleian highstand sequences. Because the specimens are so poorly preserved, the locality is mentioned only because of the area's general significance to Carboniferous stratigraphy.

Granite Mountain. - The Granite Mountain locality lies at the north end of the long belt of Chainman outcrops stretching across west-central Utah (Fig. 3). The Chainman Formation crops out extensively along the lower east slopes of Granite Mountain proper (Hose 1974), which contrary to its name, is composed mostly of Carboniferous age limestone. The localities' Viséan stratigraphy is described in detail by Webster et al. (1984), although our observations suggest revisions are needed, as was also suggested in Silberling et al. (1995).

A prominent phosphate pebble lag conglomerate bed containing abraded solitary rugose corals and pelmetozoan debris (bed 8) was identified by Webster et al. (1984) as the base of the Carboniferous at Granite Mountain (Fig. 7). We have secured several specimens of Goniatites sp. (04UTJU-2) from this unit suggesting it is no older than Asbian in age. The phosphatic unit overlies a series of black shale beds with bluish grey weathering micrite concretions that are very similar to overlying beds. There is no abrupt lithologic change where the section appears to be relatively complete. An abrupt lithologic change occurs several metres down section from the pebble lag unit where black shales and micrites are underlain by tan weathering siltstones and brown weathering fine sandstones. We did not conduct any biostratigraphic analysis of the sub-conglomerate beds, and so cannot confirm their correlation by Sandberg et al. (2008) with the Viséan-age Delle 
Figure 7. Columnar sections with the lithostratigraphy, ammonoid biozones, bed numbers, and ammonoid samples of the Granite Mountain section. Abbreviations: Sk - Skunk Spring Member; C. arcticum - Calygirtyoceras arcticum Ammonoid Biozone; Gt. primum Girtyoceras primum Ammonoid Biozone; G. deceptus - Goniatites deceptus Ammonoid Biozone.

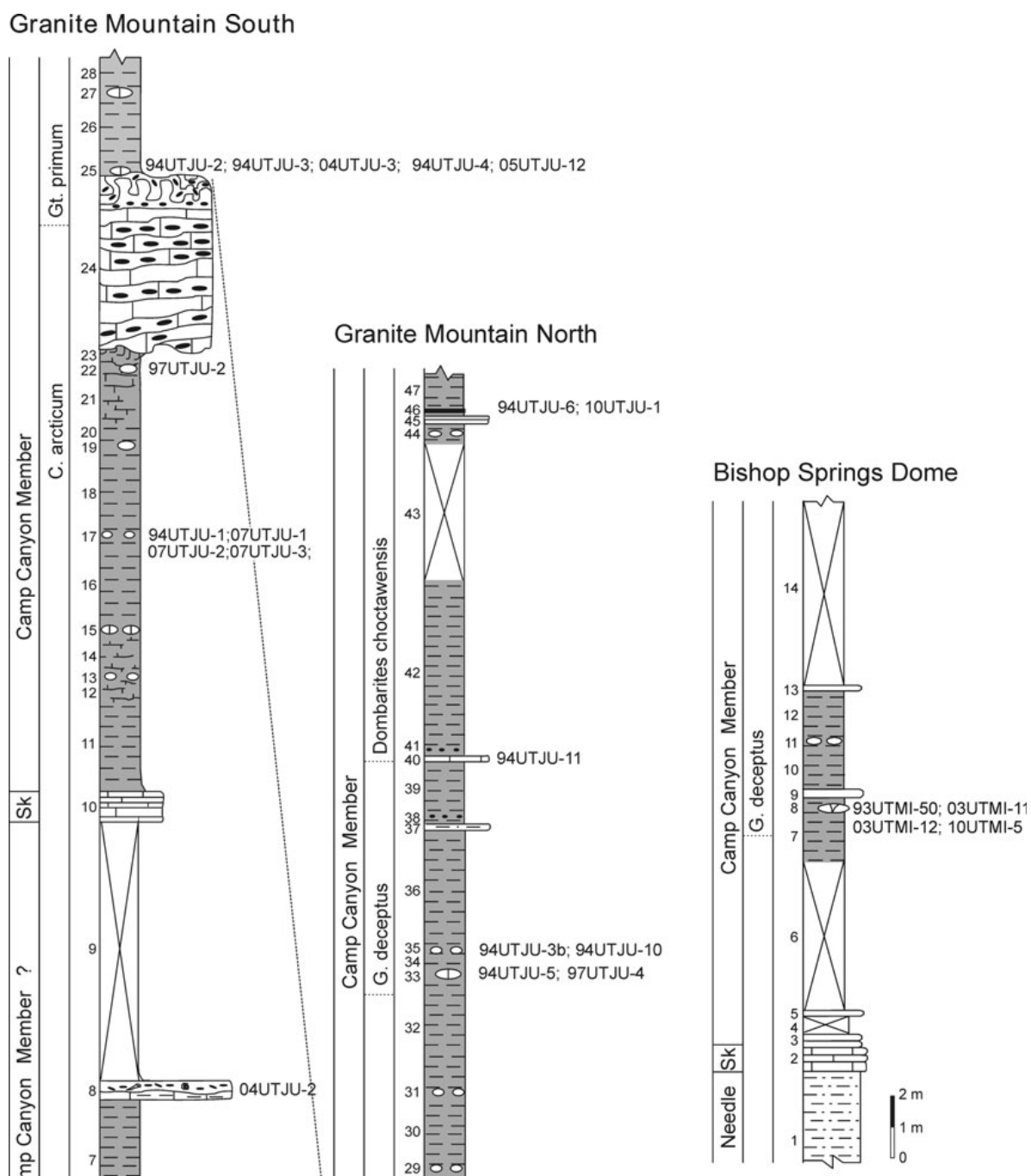

Phosphatic Member. No Joana Formation is exposed anywhere in the area and it is believed that the unit was either stripped off or never deposited in an area named the 'Granite Mountain Island' by Sandberg et al. (2008). Erosional truncation of the Joana Formation in the Bishop Springs Dome area to the south certainly suggests that post-Joana, pre-Chainman uplift occurred in the region.

At the southern end of the best Granite Mountain exposures, near the measured section reported by Webster et al. (1984), approximately eight metres above the phosphate pebble lag unit there is a poorly fossiliferous micrite (bed 10) that falls at the approximate correct stratigraphic and biostratigraphic position for the Skunk Spring Member (lower portion of the Goniatites americanus interval).
Contrary to Webster et al. (1984), we tentatively assign this unit to the Skunk Spring Member. Almost 8 metres above this unit is a prominent row of elliptical hard blue grey concretions with ammonoids (bed 17). This is the type horizon and locality for G. americanus Gordon, 1971. Four collections were made from this bed, both at the type locality (94UTJU-1, 07UTJU-1) and along strike to the north (07UTJU-2, 07UTJU-3). These collections contain Goniatites americanus Gordon, 1971, Calygirtyoceras confusionense sp. nov., C. arcticum (Gordon, 1957), Entogonites sp., Kazakhoceras bylundi sp. nov., Bollandoceras occidentale sp. nov., Dimorphoceras rileyi sp. nov., and Praedaraelites loeblichi (Miller \& Furnish, 1940).

Another similar concretionary horizon occurs just below 


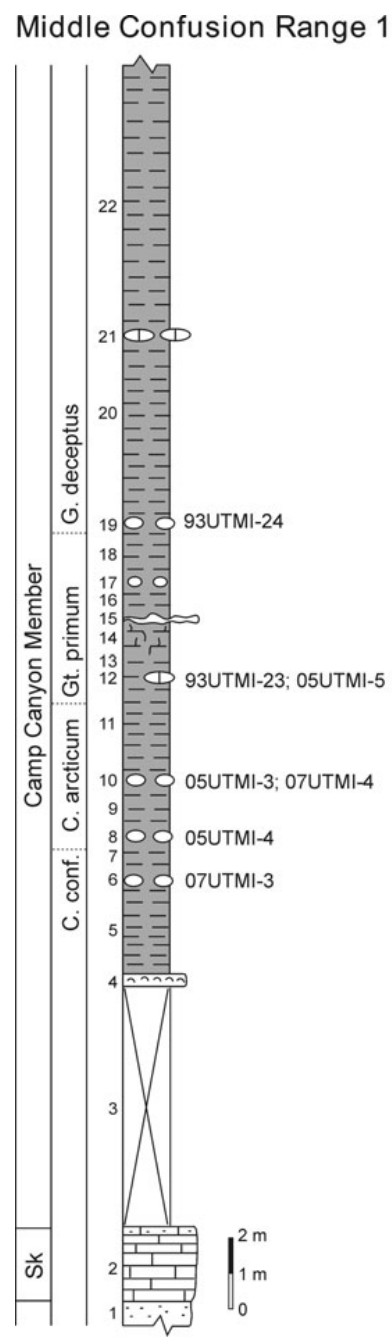

Middle Confusion Range 2

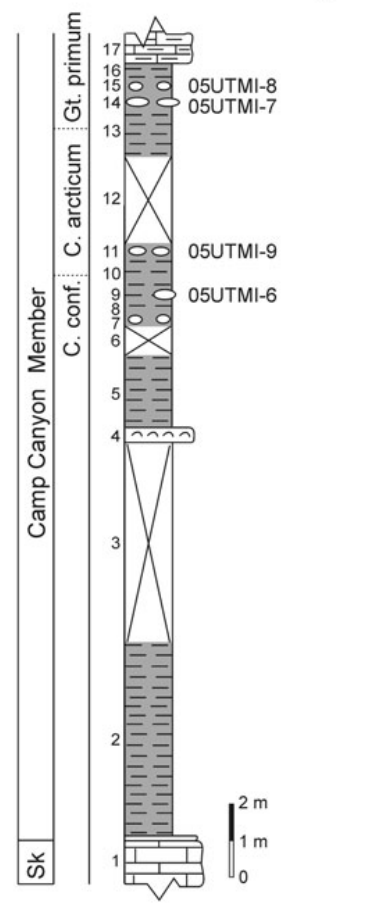

the massive cherty carbonate unit assigned by Webster et al. (1984) to the Skunk Spring Limestone Member. This concretionary horizon (bed 22) was found to contain a single nodule with several specimens of $G$. americanus (97UTJU-2). We believe that the overlying relatively thick, "endothyrid-bearing" limestone unit correlated with the Skunk Spring Limestone by Webster et al. (1984) does not actually correlate with any carbonate unit at any of the other Chainman sections we examined. Ammonoid biostratigraphic data also refutes Silberling et al.'s (1995) correlation of the Granite Mountain "endothyrid bearing" unit with a prominent upper Brigantian carbonate unit in the type Skunk Spring area (our Middle Confusion Range sections) because the former carries a Girtyoceras primum assemblage in its uppermost beds, while the latter overlies shales bearing Dombarites and Edmooroceras. Given its position in the middle of the range of Goniatites americanus, the Granite Mountain "endothyrid bearing" unit obviously correlates in its entirety with shale intervals at our other localities. The age, internally contorted fabric, pinch and swell geometry, and relationship of the Granite
Figure 8. Columnar sections with the lithostratigraphy, ammonoid biozones, bed numbers, and ammonoid samples of the sections in the Confusion Range. Abbreviations: Sk - Skunk Spring Member; C. conf. - Calygirtyoceras confusionense Ammonoid Biozone; C. arcticum - Calygirtyoceras arcticum Ammonoid Biozone; Gt. primum - Girtyoceras primum Ammonoid Biozone.

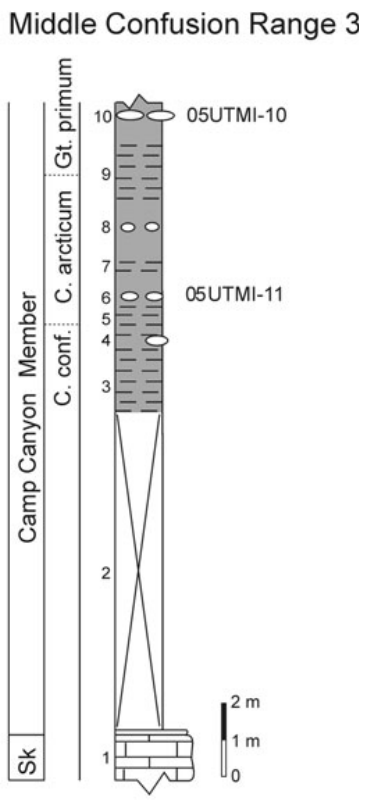

Mountain "endothyrid bearing" unit with underlying and overlying black shale units suggests that it is a locallyemplaced semi-consolidated "olistholith" derived from a shallower water setting, perhaps the "Granite Mountain Island" uplift (see Sandberg et al. 2008). Unfortunately, there are also a number of obvious post-Palaeozoic low angle and high angle fault structures that complicate interpreting the origin of this unusual bed.

Regardless of its origin, locally the "olistolith" yields large numbers of well-preserved Goniatites americanus Gordon, 1971, Calygirtyoceras arcticum (Gordon, 1957), Girtyoceras primum sp. nov., Entogonites acus sp. nov., Dimorphoceras rileyi sp. nov., and Praedaraelites loeblichi (Miller \& Furnish, 1940) (94UTJU-2, 94UTJU-3, 94UTJU-4, 94UTJU-9, 04UTJU-3, 05UTJU-12), both in its upper beds and in concretionary masses (bed 25) that develop irregularly around its upper margin or between pinch and swell lobes. Overlying this unit, approximately 24 metres of black concretionary shale yields ammonoids at two separate concretionary horizons (beds 33, 35) both of which contain Goniatites deceptus sp. nov. 
(94UTJU-3b, 94UTJU-5，94UTJU-10, 97UTJU-4, 05UTJU-13, 05UTJU-14). A phosphate-pebble lag containing abundant crinoidal debris (bed 40) yields sparse Dombarites cf. D. choctawensis Shumard, Neoglyphioceras sp. and Girtyoceras sp. (94UTJU-11, 10UTJU-1), which is the basal most assemblage above the Goniatites zone.

Bishop Springs Dome. - Because of complicated structure and extensive cover, we only found one place where the Goniatites interval can be observed in the Bishop Springs Dome area. Just west of where the road along the west flank of the structure turns east into a gap in the Joana Limestone, a relatively complete lower Chainman Formation section is present (Hose \& Ziony 1963). Exposed is a thick section of Needle Member overlain by the 1.5 metre thick Skunk Spring Member and about 17 metres of the lower portion of the Camp Canyon Member. Large numbers of G. deceptus sp. nov. occur (93UTMI-50, 03UTMI-11, 03UTMI-12, 10UTMI-5) in a prominent row of 1-2 metre long septarian concretions (bed 8), about 11 metres above the top of the Skunk Spring Member. These are the only Goniatites zone ammonoids we observed at this locality, although other concretion horizons occur above and below this bed. Upper Brigantian ammonoids occur in small phosphatic nodules approximately three or four metres higher.

Middle Confusion Range. - This is the type section of the Camp Canyon Member. The Chainman Formation is intermittently exposed along the Camp Canyon-Skunk Spring Canyon road on the east side of the northern Confusion Range (Hose \& Repenning 1964). The sections are situated in the east limb (west dipping beds) of a gently north-plunging syncline and are usually structurally simple. In the handful of places where it is well exposed, ammonoids ranging in age from Asbian to middle Pendleian can be collected. The best exposures are found approximately halfway between Skunk Springs and Ledger Canyon fork at three separate localities near the road (Fig. 3). We have informally named these localities, trending in the north direction, Middle Confusion 1, Middle Confusion 2, and Middle Confusion 3.

Well-preserved Asbian-late Brigantian ammonoids are common and lower Goniatites Zone material has been collected from five horizons (Fig. 8). The lowest horizon is a non-septarian concretionary interval about 11 metres above the base of the Camp Canyon Member from which the following taxa have been collected (e.g. 07UTMI-3): Goniatites americanus Gordon, 1971, Calygirtyoceras confusionense sp. nov., and Dimorphoceras rileyi sp. nov. 1.2 meters higher is a closely spaced non-septarian concretion couplet (beds 10, 10b of section 1) horizon (e.g. 05UTMI-3, 05UTMI-9, 07UTMI-4, 07UTMI-5) that yields Goniatites americanus Gordon, 1971, Kazakho-

\section{Conger Mountain East}

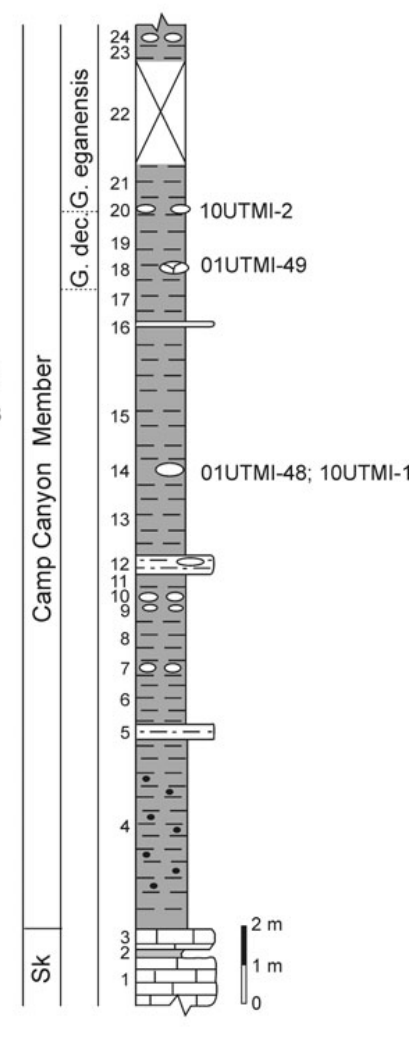

Figure 9. Columnar sections with the lithostratigraphy, ammonoid biozones, bed numbers, and ammonoid samples of the sections in the Conger Mountains. Abbreviations: N - Needle Member; Sk - Skunk Spring Member; G. dec. - Goniatites deceptus Ammonoid Biozone.

ceras bylundi sp. nov., Bollandoceras occidentale sp. nov., and indeterminate dimorphoceratids. Horizon three is three metres above the last and is characterized by large 1-2.5 metre long septarian concretions (93UTMI-23, 05UTMI-5, 05UTMI-7) from which were collected Goniatites americanus Gordon, 1971 and Metadimorphoceras sp. The intervening bed 8 yielded only Goniatites sp. (05UTMI-4). Slightly over 24 metres above the Skunk Spring Limestone is a septarian concretion horizon (bed 19 of MC-1) that yields Goniatites deceptus sp. nov. (93UTMI-24). These are the highest Goniatites Zone ammonoids we found at the locality.

Conger Mountain West. - The west side of Conger Mountain (Fig. 3) has few good exposures of the lower Camp Canyon Member from which ammonoids can be obtained even though Hintze (1974) mapped extensive outcrops. Four separate collections were made from two large non-septarian concretion horizons (beds 19 and 21) that occur estimated 14 metres above the Skunk Spring Member east of the road (01UTMI-40, 01UTMI-41, 01UTMI-42, 01UTMI-43) that contain Goniatites deceptus sp. nov. and 
indeterminate dimorphoceratids (Fig. 9). The local section appears to be largely condensed through the lower Goniatites interval. However, at least two concretionary horizons (beds 14 and 16) in the G. americanus interval are present (collections 01UTMI-46, 01UTMI-47).

Conger Mountain East. - Exposures of the lower Camp Canyon Member containing concretions can be found almost due east of Conger Spring (Fig. 3), west of the Skunk Spring-Camp Canyon road (Hintze 1974). Three small collections of ammonoids were made here: a lower one (bed 14) containing Goniatites americanus Gordon, 1971, Entogonites sp., and indeterminate dimorphoceratids (01UTMI-48, 10UTMI-1) from approximately 12 metres above the Skunk Spring Member (Fig. 9), a middle one (bed 18) consisting entirely of Goniatites deceptus sp. nov. (01UTMI-49) from six metres above the G. americanus horizon, and an upper one (bed 20) another $1.5 \mathrm{~m}$ higher with G. eganensis and Girtyoceras hamiltonense (10UTMI-2).

South Burbank Hills. - Approximately $9 \mathrm{~km}$ north of the intersection of the Big Jensen Pass road with paved highway 21, the Big Jensen Pass road jogs west around the south end of a ridge underlain by limestones of the Willow Gap Member (Hintze 1997). North-east of where the road jogs around the ridge, a couple of excellent exposures of the Camp Canyon Member occur in the middle of the north-east trending strike valley between the Joana Limestone and the Willow Gap Member (Fig. 3). The Skunk Spring Member is not exposed, but the section starts with a tan weathering siltstone filled with abundant Lingula sp. that is probably not more than a few metres above it. The section (Fig. 10) is strikingly similar to those at the Middle Confusion Range locality.

The lowest occurrence of ammonoids is in a concretionary horizon (bed 2) about 0.5 metres above the Lingula-bearing siltstone. Collecting from this horizon produced (00UTMI-22, 01UTMI-1) a few specimens of Goniatites americanus Gordon, 1971. Bed 4, about one metre above bed 2, yielded a more diverse assemblage (01UTMI-2) containing Goniatites americanus Gordon, 1971, Entogonites burbankensis sp. nov., Dimorphoceras worki sp. nov., and Metadimorphoceras mangeri sp. nov. Bed 6 approximately one metre above bed 4, is a concretionary horizon that yielded numerous specimens (00UTMI-19, 01UTMI-3) of Girtyoceras primum sp. nov., along with Goniatites americanus Gordon, 1971, Calygirtyoceras arcticum (Gordon, 1957), and Metadimorphoceras mangeri sp. nov. Bed 8 yielded the same assemblage without the dimorphoceratids (07UTMI-6). The next ammonoid bearing bed in the sequence is bed 12 which yielded a few specimens (07UTMI-7) of Goniatites americanus Gordon, 1971. Approximately $3.5 \mathrm{~m}$ above bed 12 , bed 16 concretions yielded (00UTMI-20,
01UTMI-4, 07UTMI-2, 07UTMI-8) Goniatites americanus, Girtyoceras gordoni sp. nov., and Dimorphoceras rileyi $\mathrm{sp}$. nov. The intervening concretionary horizon (bed 14) did not yield any ammonoids. Five metres above bed 16 are two closely spaced concretionary horizons (beds 24 , 25) of which the higher (bed 25) contains Goniatites eganensis sp. nov., Girtyoceras hamiltonense sp. nov., Metadimorphoceras richardsi sp. nov., and Praedaraelites loeblichi (Miller \& Furnish, 1940) (00UTMI-21, 01UTMI-5, 07UTMI-1, 07UTMI-9). Three septarian concretionary horizons between beds 16 and 24 did not yield ammonoids. A horizon of small barren septarian concretions (bed 27) occurs approximately two metres above bed 25 , over which is a $1.5 \mathrm{~m}$ thick phosphate pebble lag that we consider late Brigantian in age.

Jensen Wash. - The Chainman Formation is well exposed for nearly its entire thickness at the Jensen Wash locality (Fig. 3) of Webster et al. (1984), located on the north side of the Burbank Hills (Hintze 1997). Well-preserved ammonoids occur through the entire Asbian-early Arnsbergian stratigraphic interval, making the section particularly significant from a biostratigraphic perspective (Fig. 10).

The lowest collections are from a concretionary horizon (bed 7) that occurs 10 metres above the top of the Skunk Spring Member. Collections from that horizon (93UTMI-25, 97UTMI-9) contain Goniatites americanus Gordon, 1971, Calygirtyoceras arcticum (Gordon, 1957), Calygirtyoceras confusionense sp. nov., Entogonites borealis Gordon, 1957, Dimorphoceras rileyi sp. nov., and Metadimorphoceras mangeri sp. nov. associated with the brachiopod Leiorhynchoidea polypleura (Girty). About one metre higher is a dark grey micrite concretion horizon (bed 9, sample 97UTMI-10) containing Goniatites americanus Gordon, 1971, and Entogonites borealis Gordon, 1957.

A thin, flaggy-weathering siltstone interval (bed 11) with abundant crushed Goniatites sp., Entogonites sp., and indeterminate dimorphoceratids (97UTMI-11) occurs 25 centimetres above this. Within a distance of slightly less than two metres above the top of the siltstone are three closely spaced concretionary horizons, the lower and upper of which contain ammonoids. The lower horizon (bed 13) contains Goniatites americanus Gordon, 1971 and Entogonites acus sp. nov. (97UTMI-12), while the upper horizon (bed 17) yielded Goniatites americanus Gordon, 1971, and Girtyoceras primum (93UTMI-26). Bed 19 (sample 97UTMI-13), about 1.5 metres above bed 17, yields Goniatites sp., Girtyoceras gordoni sp. nov., Dimorphoceras rileyi sp. nov., and Kazakhoceras bylundi sp. nov. Six metres higher in the section are two closely spaced horizons (beds 26 and 28) of large, frequently septarian, grey weathering concretions that locally contain abundant ammonoids. The assemblage in both of these 
Figure 10. Columnar sections with the lithostratigraphy, ammonoid biozones, bed numbers, and ammonoid samples of the Needle Range, South Burbank Hills, and Jensen Wash sections. Abbreviations: Sk - Skunk Spring Member; C. conf. - Calygirtyoceras confusionense Ammonoid Biozone; C. arcticum Calygirtyoceras arcticum Ammonoid Biozone; Gt. primum - Girtyoceras primum Ammonoid Biozone; Gt. gordoni Girtyoceras gordoni Ammonoid Biozone; G. deceptus - Goniatites deceptus Ammonoid Biozone.

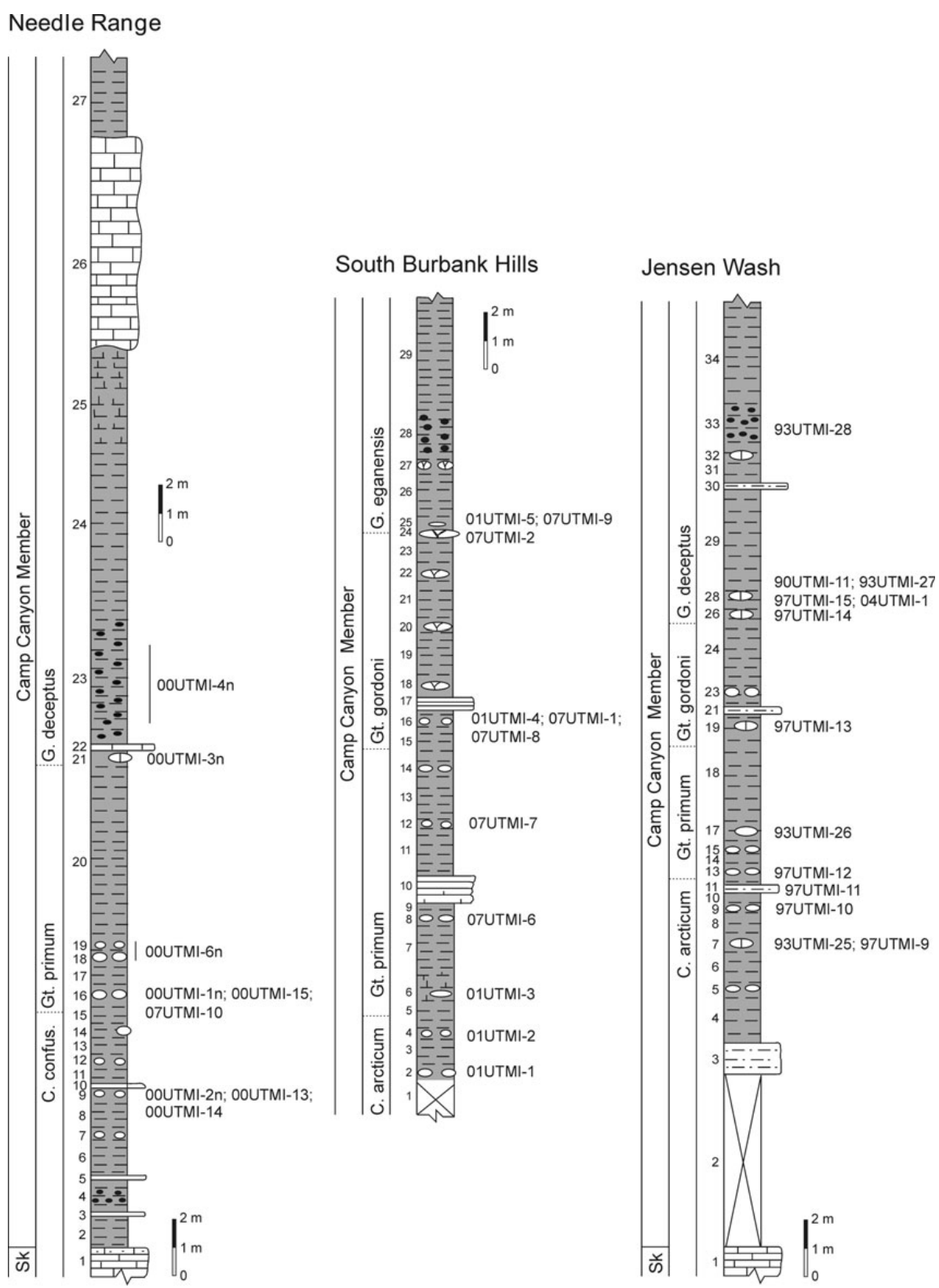

horizons appears to be essentially same. Collections from the lower concretionary bed (26) include Goniatites sp. indet. and Girtyoceras sp. indet. (97UTMI-14), while the upper bed (28) yields Goniatites deceptus sp. nov., Girtyoceras hamiltonense sp. nov., Praedaraelites loeblichi (Miller \& Furnish), and indeterminate dimorphoceratids (90UTMI-11, 93UTMI-27, 97UTMI-15, 04UTMI-1). The next ammonoids found in the section occur in bed 33, about 5 metres above bed 28. This horizon, which is a phosphate pebble lag, yields rare Pachylyroceras sp. and is almost certainly late Brigantian in age (93UTMI-28).

Needle Range. - The Goniatites zone is discontinuously exposed along the southwest-northeast trending road near, and to the north of, Mountain Home Spring (Hintze 1986, Hintze \& Best 1987). Outcrops of the Camp Canyon Member are generally poor, but ammonoids were collected in three different areas. The first is located about $400 \mathrm{~m}$ north and slightly east of where the Mountain Home Pass road enters the strike valley formed in the Chainman Formation (Fig. 3). From here, a single non-septarian concretionary horizon (bed 9) $0.75 \mathrm{~m}$ above a prominent tan weathering siltstone packed with Leiorhynchoidea polypleura (Girty) was sampled. Collections from these concretions (00UTMI-13) contain Goniatites americanus Gordon, 1971 and Calygirtyoceras confusionense sp. nov., which by its position directly over the Leiorhynchoidea polypleura bed, must be very low in the Camp Canyon Member. 
The second area to be sampled is located approximately $1.5 \mathrm{~km}$ south and slightly west of where 00UTMI-13 was collected. Here, the Mountain Home Pass road passes through good exposures of Camp Canyon Member, passing just west of the Skunk Spring Member, which is also well exposed. This is where Sadlick (1965) measured his "Needle Range" section (Fig. 10). The lowest ammonoid bearing concretions occur 4 metres above the Skunk Spring Member (bed 7), just above the prominent Leiorhynchoidea polypleura bed seen to the north. Two small collections (00UTMI-14, 00UTMI-2n) from this horizon, which is the same that produced 00UTMI-13, yielded Goniatites americanus Gordon, 1971 and Calygirtyoceras confusionense sp. nov. Five metres higher is a concretionary horizon (bed 16) packed with ammonoids from which Goniatites americanus Gordon, 1971, Girtyoceras primum sp. nov., and indeterminate dimorphoceratids were collected (00UTMI-1n, 00UTMI-15). Approximately two metres higher another concretionary bed (18) produced a few Goniatites americanus Gordon, 1971 and indeterminate dimorphoceratids (00UTMI-6n). Almost six metres higher, a horizon of large septarians produced a few specimens of Goniatites deceptus sp. nov. and Girtyoceras hamiltonense sp. nov. (00UTMI-3n). A thin platy weathering limestone with sparse crinoidal debris similar to bed 40 of the Granite Mountain section separates the lirate goniatite concretionary bed from a five metre thick ?late Brigantian phosphate pebble lag interval (bed 23) which yields ?Lusitanoceras sp. and Neoglyphioceras sp. (00UTMI-4n).

The third area from which ammonoids were collected is $3 \mathrm{~km}$ south-west of Sadlick's measured section, where the Mountain Home Pass road turns sharply west. Immediately east of the road a few concretions were found weathering from poor exposures of the Camp Canyon Member. Goniatites americanus and Entogonites acus sp. nov. were collected from a single loose concretion (sample 07UTMI-10). There are several low angle faults cutting the immediate area and it was not possible to precisely estimate the stratigraphic position of this sample but it must be from somewhere near bed 16.

\section{Biostratigraphy}

\section{Ammonoids}

Previous work. - Prior to Mackenzie Gordon's pioneering work, all Late Viséan and early Serpukhovian ammonoids from the study area were placed into a single homogeneous faunal zone of little practical value (Miller \& Furnish 1940, Youngquist 1949a, Miller et al. 1952). Gordon (1970; see also Sadlick 1965, Webster et al. 1984) was able to recognize three distinct Late Viséan range zones, which are, from lowest to highest, the 'Goniatites americanus', 'Goniatites multiliratus', and 'Goniatites granosus' ammonoid biozones. Gordon's zones span the late Asbian and Brigantian stages, and the lower two approximate the interval of interest in this study. Gordon's scheme has been used relatively unchanged until this work (e.g. Sadlick 1995). Based on the presence of G. americanus in both Utah and Alaska, as well as the supposed presence of the Oklahoma species G. multiliratus in Utah and Nevada, this zonal system has been extended throughout the North American continent (Gordon 1970).

Present study. - Our new systematic appraisal of Asbian and Brigantian ammonoids from the Great Basin and United States Midcontinent demonstrates two fundamental issues that necessitate development of a new zonal scheme. The Chainman Formation taxon thought by Gordon to represent the Oklahoma species Goniatites multiliratus is in fact an older homeomorphic form with a distinct suture and co-occurring assemblage. It is newly described here as Goniatites deceptus sp. nov. Thus, we cannot confidently recognize the species Goniatites multiliratus in the Chainman Formation. It is probably present (e.g. bed 40 of Granite Mountain North section) along with Girtyoceras meslerianum (Girty, 1909), but the material is poorly preserved and we cannot assign it to species without sutural data. Secondly, we have now documented a much higher overall diversity than recognized by any previous study. With this better taxonomic discrimination, it is possible to demonstrate the study area preserves an exceptional record of the early evolution of Goniatites, Girtyoceras and Calygirtyoceras. The ubiquitous nature and relatively short stratigraphic ranges of species of these genera help us to recognize seven biozones in roughly the same interval occupied by Gordon's two (Figs 11, 12). The four lower biozones are characterized by girtyoceratids and the three higher biozones by species of Goniatites. These are detailed below.

Calygirtyoceras confusionense Ammonoid Biozone. - The Calygirtyoceras confusionense range zone is defined as the interval between the first occurrence of the zonal namebearer and first occurrence of Calygirtyoceras arcticum. Associated taxa include Entogonites borealis Gordon 1957 and Dimorphoceras rileyi sp. nov. (Fig. 12). It is best represented by the lowest concretionary horizons at Jensen Wash and the Needle Range, but can also be recognized at the Middle Confusion Range section. Concretions from this zone typically have associated shelly benthos such as leiorhynchid brachiopods as they occur just above the brachiopod-rich basal beds of the Camp Canyon Member. The zone cannot currently be recognized anywhere outside Utah, but it is possible that it could be diagnosed in the Kuna Formation of Alaska as well as over most of the Antler Basin. 


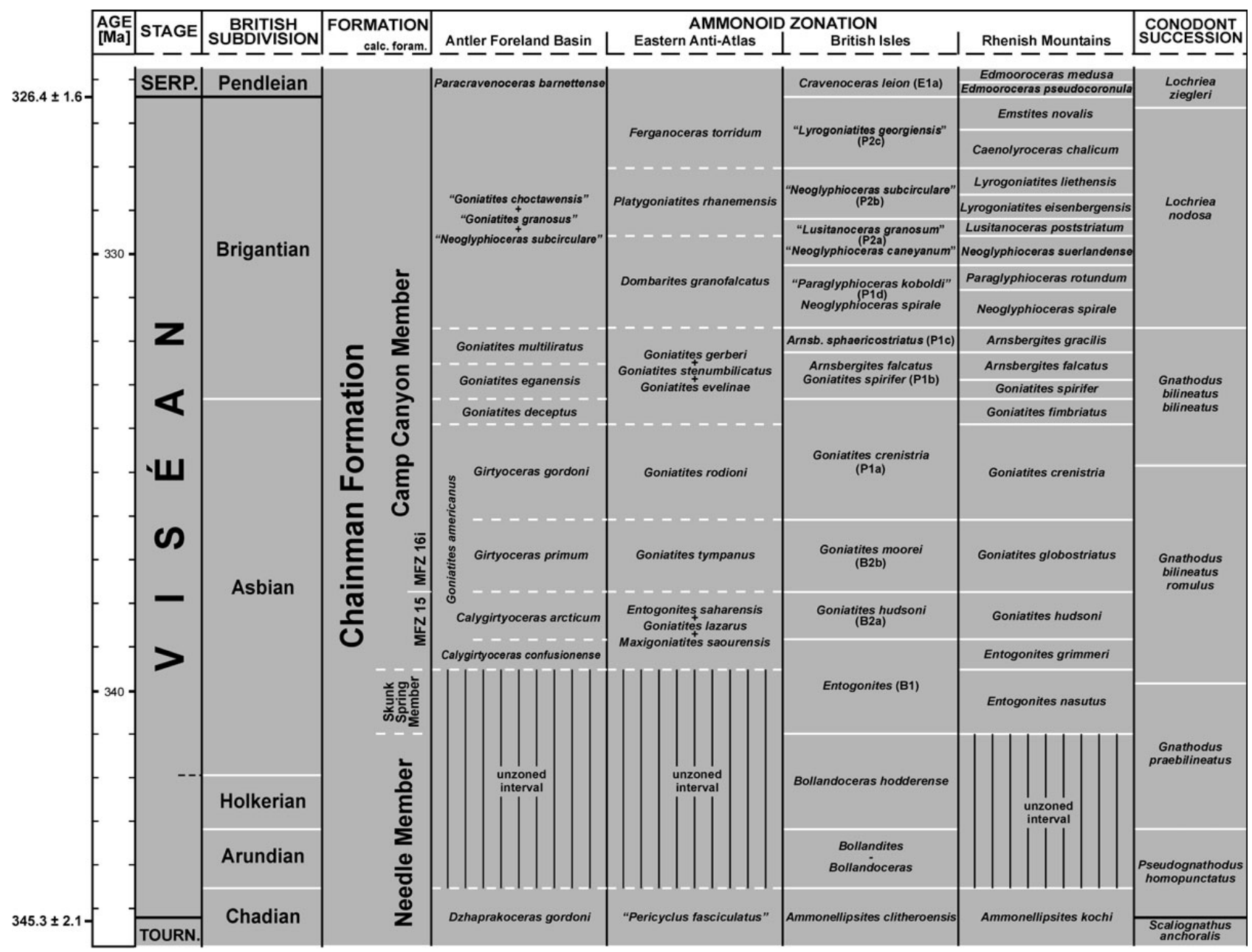

Figure 11. Stratigraphic correlation of chronostratigraphy, lithostratigraphic units, ammonoid zonations of various regions, and conodont succession of the Viséan.

It is important that the stratigraphic position of this zone is directly above the first appearance of the platform conodont Gnathodus bilineatus, which correlates roughly with the Meramecian-Chesterian series boundary in North America. This would suggest it is close in age to the famous Greencastle ammonoid assemblage from the Ste. Genevieve Limestone of west-central Indiana (Miller \& Gurley 1896, Smith 1903). The Greencastle assemblage is not currently known to contain Calygirtyoceras or Entogonites, but it does contain primitive Goniatites (cf. G. americanus Gordon, 1971), and primitive Kazakhoceras (D.M. Work unpublished data, ALT, unpublished data) that are similar to those found in the lower G. americanus assemblages of Utah and Nevada. Thus it appears that the Greencastle assemblage is either an age equivalent of, or more likely, slightly older than the $C$. confusionense interval.

Calygirtyoceras arcticum Ammonoid Biozone. - This zone is defined as the interval between the first appearance of
Calygirtyoceras arcticum and the first appearance of Girtyoceras primum sp. nov. The zonal index is typically a common and conspicuous component in assemblages within the zone, however it is surprisingly uncommon in the Middle Confusion Range sections. Accompanying taxa include Goniatites americanus Gordon, 1971, Bollandoceras occidentale sp. nov. Dimorphoceras rileyi sp. nov., Kazakhoceras bylundi sp. nov., and Entogonites borealis (Gordon, 1957). It is especially well displayed at the Jensen Wash (bed 7 to bed 9), Southern Burbank (below bed 6), and Granite Mountain (bed 17 to 22) sections, but it is probably diagnosable in almost all the Utah Chainman Formation outcrops. We designate Granite Mountain as the reference section for the zone. In addition, we also collected the zonal namebearer at the Rosebud Spring section in eastern Nevada, but poor ammonoid preservation in the sediment starved eastern White Pine County sections prevents recognition of it over most of that area. It is possibly represented in the lower portion of the Chainman Formation in western White Pine County and eastern Nye County where 


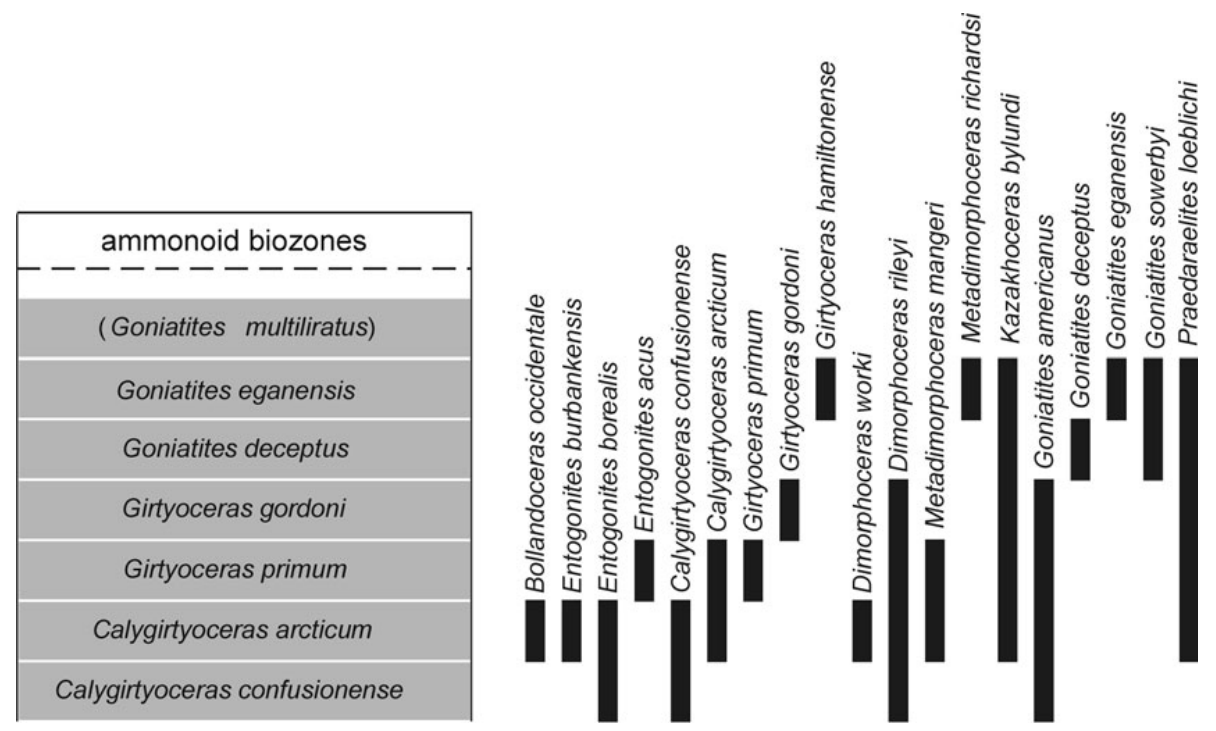

Figure 12. Stratigraphic occurrence of the Asbian and early Brigantian ammonoid species in the Antler Foreland Basin.

there is at least two hundred metres of section below lower Brigantian ammonoid horizons. However, we have not secured any ammonoids of this general time frame from that region probably due to facies controls.

The zone can be widely recognized in Alaska's Kuna Formation, which is the type region for the zonal namebearer. Ammonoids of this age have not been recognized anywhere else in North America primarily due to facies controls.

Girtyoceras primum Ammonoid Biozone. - This zone is defined as the interval between the first appearance of Girtyoceras primum sp. nov. and the first appearance of Girtyoceras gordoni sp. nov. It is readily diagnosed at most Utah Chainman Formation outcrops and its assemblage is the most consistently present of any in the lower zones. Jensen Wash (bed 13 to bed 18) is designated as the reference section for this zone because its relationship with the overlying G. gordoni zone is best shown there. The Southern Burbank Hills also shows this relationship and serves as a supplemental reference section.

Ammonoids from this zone are most abundant at Granite Mountain where they can readily be shown to succeed those of the Calygirtyoceras arcticum Ammonoid Biozone. Here the G. primum assemblage is largely associated with the thick carbonate allochthonous body (bed 24) mistakenly referred to the Skunk Spring Limestone by Gordon (1971) and others (e.g. Webster et al. 1984). Ammonoid taxa associated with G. primum include Goniatites americanus Gordon, 1971, Calygirtyoceras arcticum (Gordon, 1957), Entogonites acus sp. nov., Dimorphoceras rileyi sp. nov., Metadimorphoceras mangeri sp. nov., and Praedaraelites loeblichi (Miller \& Furnish, 1940). This zone cannot be recognized with certainty outside of the Great Basin region of the USA, but it is probable that it would eventually be recognized in the Kuna Formation of the Lisburne Group in Alaska.
Girtyoceras gordoni Ammonoid Biozone. - This zone is defined as the interval between the first appearance of the zonal namebearer and the first appearance of Goniatites deceptus. Because the zonal namebearer is only found at the Jensen Wash and South Burbank Hills sections, those are the primary reference sections, with the Jensen Wash section being the type. Associated taxa include Goniatites americanus, Dimorphoceras rileyi sp. nov., and Kazakhoceras bylundi sp. nov.

This zone cannot be recognized outside the type area in western Utah, and is obviously an interval that is poorly represented in North America, primarily due to facies controls. We would expect it to be represented in the lower portion of the Chainman Formation in the western portion of the study area, but as we have stated before, diagnostic ammonoids have not yet been found there in the thick section below the Goniatites deceptus zone. As with all the earlier biozones in the eastern portion of the study area, this interval is a fossil-poor nodular phosphate sequence that resulted from extreme sediment starvation. Although we cannot recognize this zone anywhere else in North America, it very likely could be represented in the Kuna Formation of the Lisburne Group and correlative strata in northern Alaska.

Goniatites deceptus Ammonoid Biozone. - This zone is defined as the interval between the first appearance of the zonal namebearer and the first appearance of Goniatites eganensis sp. nov. This is the first zone that can be widely recognized across the entire study area. Virtually every section we examined outside of the central starved sediment facies belt that has this interval exposed yields well preserved ammonoids. Large collections from this zone were made at the Duckwater, Jensen Wash, Granite Mountain and Middle Confusion sections. The Southern Burbank Hills section is selected as the primary reference section for the zone because there it is possible to recognise 
both its lower and upper limits. Assemblages in this zone are thoroughly dominated by the genus Goniatites $(G$. deceptus sp. nov.), but also yield Praedaraelites loeblichi and small, indeterminate dimorphoceratids. We cannot currently recognize this zone anywhere outside the study area.

Goniatites eganensis Ammonoid Biozone. - This zone is defined as the interval between the first appearance of $G o$ niatites eganensis sp. nov. and the first appearance of $\mathrm{Go}$ niatites multiliratus Gordon 1962. It can be recognized on both the east and west margins of the study area, but unlike the previous Goniatites deceptus zone, it can also be recognized, because of lowered sea levels, in the central portion of the sediment starved belt (e.g. Trough Springs section). Because of the general lack of $G$. multiliratus in the Great Basin region due to widespread sediment starvation at its top, no single section contains a complete record of the zone. However, the Southern Burbank Hills and White Pine Range sections are excellent references for its lower boundary. Assemblages from this interval contain, in addition to the zonal nominate species, Girtyoceras hamiltonense sp. nov., Metadimorphoceras richardsi sp. nov., and Praedaraelites loeblichi (Miller \& Furnish, 1940).

The Goniatites eganensis Ammonoid Biozone is the lowest of the Brigantian zones in this study that we can recognize elsewhere in North America. The zonal index ammonoid occurs widely on the northern margin of the Ouachita-Marathon Foreland Basin sequence, where it has been consistently and mistakenly referred to Goniatites crenistria (e.g. Smith 1903, Girty 1911, Gordon 1965). Based on our own collecting and evaluation of the literature, we now recognize this zone at the following localities: Helms Formation (Barnett of some authors) in the northern Sierra Diablo Range, Texas; Caney Shale, on both the north and south sides of the Arbuckle Mountains, Oklahoma; upper portion of the Moorefield Formation (sensu Gordon 1965), Batesville, Arkansas. In all of the eastern sections the ammonoids of this zone are the lowest found in the Brigantian succession and are overlain by Goniatites multiliratus-Girtyoceras meslerianum assemblages.

Goniatites multiliratus Ammonoid Biozone. - Defined as the interval between the first appearance of the zonal index ammonoid and Sulcogirtyoceras limatum (Miller \& Faber, 1892), this zone can only tentatively be recognized in the Great Basin region at the Granite Mountain section where it is the highest zone in the stratigraphic interval targeted by this study. The primary reference sections are designated as the Caney Shale outcrops near Ada, Pontotoc County, Oklahoma, which yielded the types for the nominate species (Gordon 1965). Poorly preserved ammonoids collected from bed 40 of the Granite Mountain North sec- tion probably represent $G$. multiliratus and G. meslerianum, but additional collecting is needed to confirm this. In the eastern part of the study area this interval is typically a sediment-starved phosphate pebble or grain-bearing black shale yielding only very rare macrofossils. In western sections, the interval is mostly a thick septarian concretion-bearing shale interval that yields only rare fossils and virtually no ammonoids. The zone can be readily recognized at all of the Texas, Oklahoma, and Arkansas sections discussed above. Recent collecting by ALT has also shown it to be the lowest recognizable ammonoid zone in the Barnett Shale of the Llano Uplift region near San Saba, Texas, where the zonal index and Girtyoceras meslerianum commonly occur in calcareous concretions approximately one metre above the base of the formation. The girtyoceratids Sulcogirtyoceras and Edmooroceras succeed Girtyoceras meslerianum in both the Great Basin and Midcontinent US sections, but evaluation of these assemblages is beyond the scope of this paper.

\section{Conodonts}

Using conodonts, Sandberg et al. (1980) divided the interval under study here into two zones; a lower Cavusgnathus-Paragnathodus homopunctatus Conodont Biozone and an upper Cavusgnathus-Gnathodus girtyi girtyi Conodont Biozone. We have concluded that these two zones roughly correspond respectively to Gordon's Goniatites americanus and Goniatites multiliratus Ammonoid Biozones. However, no attempt was made by either of those authors to make a firm correlation with the other's zonal scheme and higher precision correlation between the two systems is not presently possible. We suspect, as in previous ammonoid studies, that the conodont diversity and stratigraphic resolution is underrepresented in previous work and that this would be a fruitful area for future research. Tynan (1980) did report the first occurrence of the platform element Gnathodus bilineatus, an extremely important global biostratigraphic datum within the early Asbian, to be in the top of the Skunk Spring Limestone Bed (Fig. 11) in his Needle Range section and referred the present study interval to his 'Lower Zone A'. This demonstrates that the top of the Skunk Spring Member contains the Meramecian-Chesterian series boundary (Repetski \& Stamm 2009) and that the lowest beds of the Camp Canyon Member are equivalent to the Ste. Genevieve Limestone of the Mississippi River Valley (type area for the Chesterian).

\section{Calcareous foraminifera}

Webster et al. (1984) divided the study interval into two zones based on calcareous foraminifera; a lower interval 
assigned to Mamet Foraminiferal Zone 15 and an upper interval referred to Mamet Foraminiferal Zone 16i. As a rule, calcareous foraminifera do not occur in the deep-water black shale sequences from which most of the ammonoids in this and other studies were collected. Fortunately, they do occur in abundance in the allochthonous carbonate body (our bed 24 of the Granite Mountain section) erroneously referred to the Skunk Spring Limestone Bed by Webster et al. (1984). Foraminifera diagnostic of MFZ-15 (Eoendothyranopsis utahensis Zeller assemblage) occur through all but the highest one metre of this unit, while the upper metre contains a Neoarchaediscus-early Zellerinella assemblage diagnostic of MFZ-16i. Thus, the boundary between these two zones, which approximates the foraminifera-based Meramecian-Chesterian North American Stage Boundary advocated by Maples \& Waters (1987), appears to occur within the unit. As a result, we roughly correlate the 15-16i foraminiferal zone boundary with the Calygirtyoceras arcticum-Girtyoceras primum ammonoid zonal boundary (Fig. 11). However, we want to note that this is at least two ammonoid zones higher than the currently accepted, conodont-based Meramecian-Chesterian stage boundary horizon (Repetski \& Stamm 2009). Foraminifera diagnostic of Mamet Foraminiferal Zone 16s [Neoarchaediscus parvus (Rauzer-Chernoussova) and N. regularis (Suleimanov)] occur in our bed 40 of the Granite Mountain section (Webster et al. 1984), which would suggest that the base of this zone corresponds roughly with the entry of Dombarites (Fig. 11).

\section{Global correlations}

Global correlations of the Antler ammonoid faunas are impeded for a number of reasons:

- All of the ammonoid species found in the Antler Foreland Basin are probably endemic to North America.

- Despite the fact that all Antler Foreland Basin genera are cosmopolitan, their stratigraphic ranges are not all concordant with those observed elsewhere. For instance: (1) Goniatites and Entogonites only range concurrently in the Rhenish Mountains for a few centimetres. These two genera do co-occur in the Anti-Atlas for a more extended interval, but in the Antler Foreland Basin they range together through three biozones. (2) In the Antler and Illinois basins, Kazakhoceras has a much lower stratigraphic occurrence than anywhere else.

- Some of the Brigantian ammonoid genera from the North Variscides, e.g. Arnsbergites, Hibernicoceras, and Paraglyphioceras have not been recorded from North America. Furthermore, we are fairly sure that Goniatites ranges higher stratigraphically in North America than in Europe and that the timing and trends in evolution within clades differ slightly between different global regions. The girtyoceratids, for instance show a very clear, gradual evolution in the Antler Foreland Basin, which is difficult to compare with the more iterative pattern in the North Variscides.

In spite of these problems, we propose the following two key ammonoid events are particularly useful for intercontinental correlation; (1) the lowest occurrence of characteristic Girtyoceras (e.g. G. primum sp. nov.), and (2) the lowest occurrence of Sulcogirtyoceras. Other indicators such as the ranges of Entogonites and Calygirtyoceras can also be used for correlation in a more general way. In addition, key global foraminiferal and conodont events (first occurrences of Neoarchaediscus and Gnathodus bilineatus, respectively) support our ammonoid-based datums and collectively serve as the basis for the global correlations discussed below.

Great Britain (Craven Basin, Peak District). - Equivalent successions in North England contain rich, well-preserved ammonoid faunas in thick basinal shale sequences that have been well documented over the years by Bisat (1924, $1934,1952)$ and Moore $(1936,1946)$. They were summarized by Riley (1993) and updated by Korn \& Tilsley (2006). The general interval under study spans the Asbian and early Brigantian stages and is divided into the $\mathrm{B}_{1}, \mathrm{~B}_{2}$, and $\mathrm{P}_{1}$ Chronozones, with additional subdivisions based primarily on ammonoid and pelagic bivalve species ranges. Precise correlation between the platform carbonate-based type sections for both the Asbian and Brigantian stages and their basinal, ammonoid-rich counterparts has long been problematic (Riley 1993). However, the Asbian-Brigantian Stage Boundary is currently designated as the base of the $\mathrm{P}_{1 \mathrm{~b}}$ (Poty \& Hance 2006, Cozar et al. 2005).

The first occurrence of true Girtyoceras in the British succession occurs at the base of the $\mathrm{B}_{2 b}$ (Riley 1993), represented by such species as $G$. deani and $G$. simplex. These forms are similar to the North American taxon G. primum and possibly represent an equivalent stage of phylogenetic development. The co-occurrence of $G$. primum with the highest occurring specimens of Entogonites in Utah, however, differs from the situation in North England, because Entogonites doesn't range higher than the upper $\mathrm{B}_{1}$ or $\mathrm{B}_{2 \mathrm{a}}$ in Great Britain (Riley 1993).

Our correlation of the G. meslerianum Biozone with the British $\mathrm{P}_{1 \mathrm{c}}$ is based on the position of both of those intervals below the first appearance of Sulcogirtyoceras. Since both the $\mathrm{P}_{1 \mathrm{a}}$ and $\mathrm{P}_{1 \mathrm{~b}}$ are defined in Britain by species of endemic European goniatites and there are no significant global ammonoid events in that interval, we cannot confidently correlate the Goniatites deceptus-Goniatites eganensis interval with any greater precision than $\mathrm{P}_{1 \mathrm{a}}-\mathrm{P}_{1 \mathrm{~b}}$ undifferentiated.

The previously mentioned first occurrence of G. bilineatus s.l. in the uppermost Skunk Spring Limestone bed 
(Tynan 1980) of Utah is another important datum for global correlation because G. bilineatus s.l. is well documented to first appear near the base of the $\mathrm{Cf6} \beta$ foraminiferal zone throughout Western Europe (Conil et al. 1990, Meischner \& Nemyrovska 1999, Cozar et al. 2005). That event horizon is now well constrained (Cozar et al. 2005) as early Asbian (middle $\mathrm{B}_{1}$ ) and is remarkably parsimonious with the ammonoid data from Utah (Fig. 11).

Germany (Rhenish Mountains). - The Viséan Kulm facies of north-western Germany contains a rich succession of ammonoids (Korn 1988, 1990). The ammonoid biostratigraphy of this region was revised by Korn (1996) and subsequently integrated into a comprehensive relative time scale correlated with the standard Viséan Series of Belgium and the Asbian and Brigantian stages of England (Korn \& Kaufmann 2009). Although differing in some particulars, the German zonation can be correlated with the British succession on a virtual one-to-one basis and many zonal indices are based on the same taxa. As a result, correlations between the German and Great Basin successions are based largely on the same arguments as those made for England. We also note that Calygirtyoceras moorei (Nicolaus, 1963), which occurs within the upper portion of the Goniatites hudsoni Zone in the Rhenish Mountains, displays morphology suggestive of the stage of development exhibited by girtyoceratids such as C. arcticum. Meischner \& Nemyrovska (1999) document that in the Rhenish Mountains the first occurrence of $G$. bilineatus, in the form of the subspecies $G$. bilineatus romulus, enters within the top of the Entogonites nasutus Zone, which argues for an early Asbian (British middle $\mathrm{B}_{1}$ ) assignment for the top of the Skunk Spring Limestone Bed and is in complete agreement with all our data from Utah.

North Africa (Anti-Atlas). - Reports of late Viséan ammonoids from Algeria and Morocco have been made for many years (Delépine 1941), however, only recently has the succession been documented in enough detail that relatively detailed comparisons can be made with Europe and North America (Korn et al. 1999, 2005, 2007; Klug et al. 2006 and references within). The Tafilalt, particularly the area around the Gara el Itima, has produced a succession of which four assemblages correlate closely with those observed in North America. The lowest is characterized by Goniatites lazarus, Maxigoniatites saourensis, Maxigoniatites tafilaltensis; Entogonites saharensis, Bollandoceras ergchebbiense, Beyrichoceras elabiodiense, Calygirtyoceras darkaouense, and Prolecanites sp., referred to the local Entogonites-Maxigoniatites Assemblage Zone (Korn et al. 2007). In Morocco, the association of Calygirtyoceras darkaouense, which has a widely evolute, almost cadyconic juvenile conch, with Entogonites saharensis closely paral- lels the Utah association of Calygirtyoceras confusionense with Entogonites borealis. We believe these two assemblages correlate closely in time but are unable to further subdivide this interval based on currently available data from Africa. The overlying low diversity Goniatites tympanus assemblage consists of the nominate taxon associated with Irinoceras. Goniatites tympanus Korn, Bockwinkel \& Ebbighausen, 2007 compares very closely to the European taxon G. moorei, leaving Korn et al. (2007) to conclude that the Moroccan ammonoid assemblage correlates with the upper Asbian $\left(\mathrm{B}_{2}\right)$ of the British Isles, making it the equivalent of the Calygirtyoceras arcticum interval of Utah. Overlying the Goniatites tympanus assemblage is a more diverse assemblage containing $G$. rodioni Korn \& Ebbighausen, 2006, advanced Calygirtyoceras (C. zrigatense Korn \& Ebbighausen, 2006), Itimaites, and Prolecanites. The phylogenetic stage of the Calygirtyoceras in this assemblage suggest it is equivalent our $G$. primum or G. gordoni intervals, most likely the former.

The highest Goniatites interval in Morocco is characterized by a low diversity assemblage consisting of three species of the genus (G. stenumbilicatus Kullmann, 1961, G. gerberi Korn \& Ebbighausen, 2006, and G. evelinae Korn \& Ebbighausen, 2006). The lack of accessory taxa in the Moroccan assemblage make precise correlations difficult, but the species appear to be close phylogenetic equivalents of G. multiliratus Gordon (Korn \& Ebbighausen in Klug et al. 2006), G. deceptus sp. nov., and G. eganensis sp. nov., leading us to make tentative correlations with that general interval in the Utah sections. Thus in North Africa (Palaeotethyan) as well as in North America, Goniatites appears to range stratigraphically higher than in Western Europe.

\section{Palaeontological descriptions}

Descriptive terminology for conch morphology is patterned after Korn (2010). Abbreviations of conch dimensions (Fig. 13A) are: conch diameter (dm), whorl width (ww), whorl height (wh), umbilical width ( $\left.\mathrm{uw}=\mathrm{dm}_{1}-\mathrm{wh}_{1}-\mathrm{wh}_{2}\right)$ and aperture height (ah). The whorl expansion rate (WER) is calculated using the algorithm of Korn \& Klug (2007): WER $=[\mathrm{dm} /(\mathrm{dm}-\mathrm{ah})]^{2}$ or $\left(\mathrm{dm}_{1} / \mathrm{dm}_{2}\right)^{2}$. The imprint zone rate (IZR) characterizes the whorl overlap, and can be calculated by: IZR $=($ wh-ah $) /$ wh. the terminology of the suture lines (Fig. 13B) is taken from Korn et al. (2003a).

The material described in the following account is held in the following collections with the prefixes: UMNH IP Utah Museum of Natural History, Salt Lake City; MB.C. Cephalopod collection in the Museum für Naturkunde Berlin; USNM - U.S. National Museum, Washington; SUI - State University of Iowa, Iowa City. 

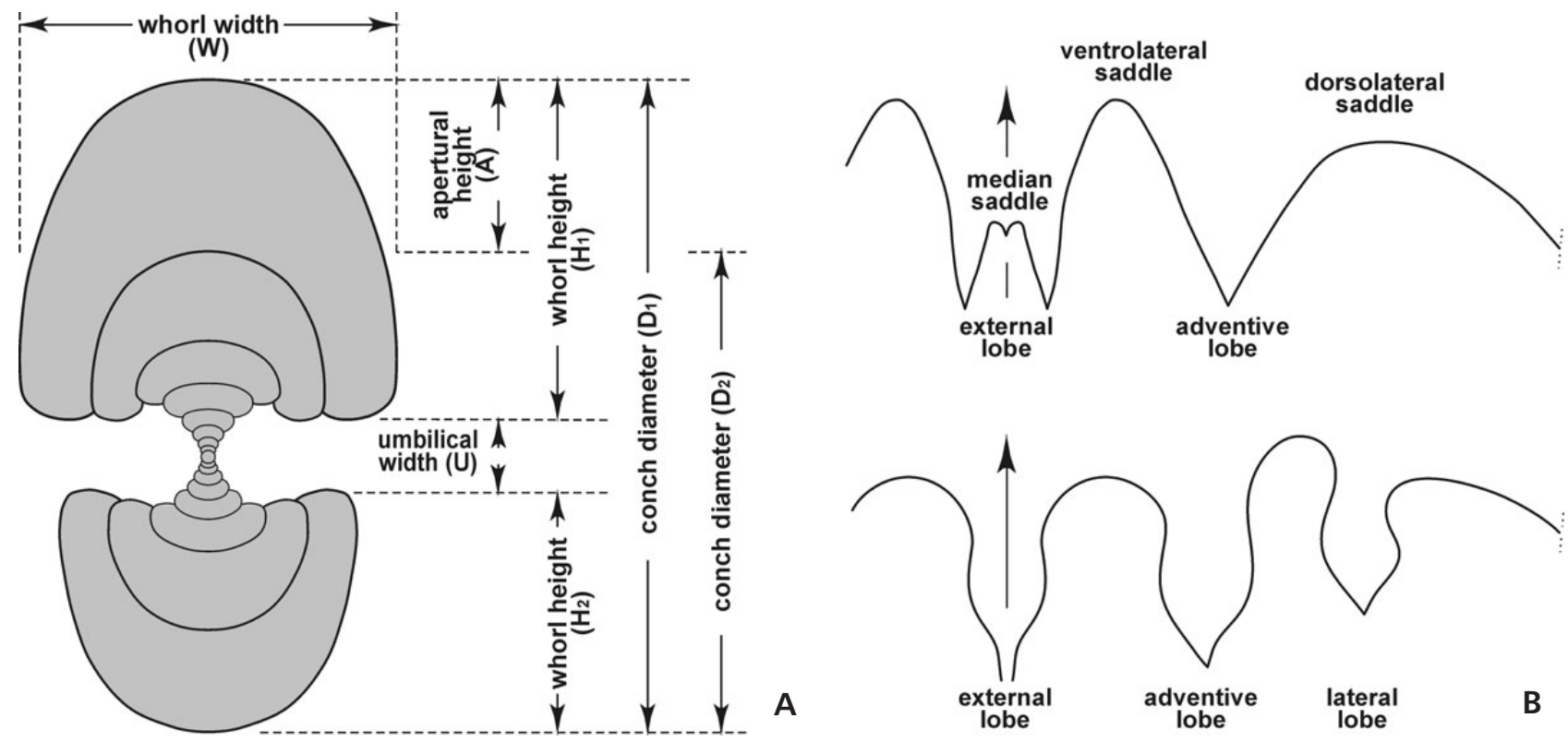

A

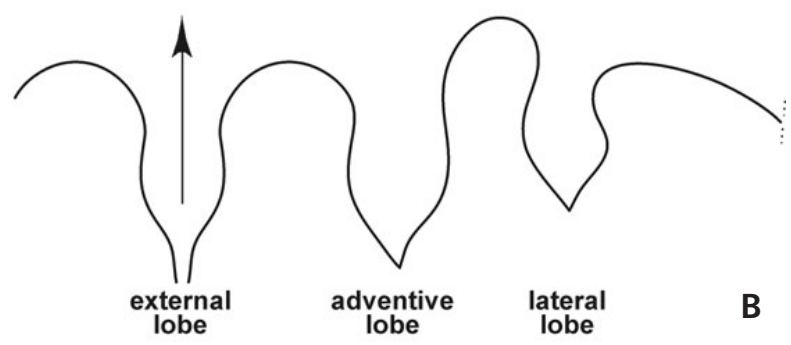

Figure 13. A - descriptive terms for the conch morphology of the ammonoids. $\bullet \mathrm{B}-$ descriptive terms for the suture lines of the ammonoids described here.

Order Goniatitida Hyatt, 1884

Suborder Goniatitina Hyatt, 1884

Superfamily Pericyclaceae Hyatt, 1900

Included families. - Pericyclidae Hyatt, 1900; Muensteroceratidae Librovitch, 1957; Intoceratidae Kusina, 1971; Maxigoniatitidae Korn, Klug \& Mapes, 1999; Entogonitidae Ruzhencev \& Bogoslovskaya, 1971.

Family Maxigoniatitidae Korn, Klug \& Mapes, 1999

Included subfamilies. - Maxigoniatitinae Korn, Klug \& Mapes, 1999; Dzhaprakoceratinae Korn, Bockwinkel \& Ebbighausen, 2010; Bollanditinae Bockwinkel, Korn \& Ebbighausen, 2010.

Subfamily Maxigoniatitinae Korn, Klug \& Mapes, 1999

Subfamily definition. - Maxigoniatitidae with a subevolute or evolute (uw/dm $=0.35-0.55)$ juvenile stage with weakly or moderately depressed whorl cross section. Ornament usually with biconvex, fine growth lines and spiral lines in some genera. Suture line with V-shaped external lobe, flanks of the external lobe usually strongly sinuous.

Included genera. - Benimehlalites Bockwinkel, Korn \& Ebbighausen, 2010; Beyrichoceras Foord, 1903; Bollandoceras Bisat, 1952; Maxigoniatites Korn, Klug \& Mapes, 1999; Pachybollandoceras Bockwinkel, Korn \& Ebbighausen, 2010.

\section{Genus Bollandoceras Bisat, 1952}

Type species. - Beyrichoceras submicronotum Bisat, 1934 (original designation); subjective junior synonym of Bollandoceras micronotum (Phillips, 1836).

Genus definition. - Maxigoniatitins with moderate to major ontogenetic changes of conch morphology; adult conch discoidal $(\mathrm{ww} / \mathrm{dm}=0.35-0.45)$ with rapidly expanding whorls (WER above 2.10 in stages larger than $10 \mathrm{~mm}$ conch diameter); umbilicus moderately wide to wide (uw/dm $=0.40-0.50)$ in juveniles and narrow or almost closed in the adult stage. Shell ornament consisting of fine biconvex growth lines with a rather deep ventral sinus; steinkern often with constrictions parallel to the growth lines. Suture line with very narrow to narrow, V-shaped external lobe with gently sinuous, slightly diverging flanks; secondary prongs of the external lobe hook-shaped; median saddle very low or low; ventrolateral saddle usually broadly rounded; adventive lobe $\mathrm{V}$-shaped, often much shallower than the external lobe.

Included species. - aridum: Bollandoceras aridum Bockwinkel, Korn \& Ebbighausen, 2010, p. 233; Gourara, Algeria; bashatchense: Bollandites bashatchensis Popov, 1968, p. 38; Tien Shan; bellmanense: Dzhaprakoceras bellmanense Riley, 1996, p. 51; Lancashire; boreus: Bollandites boreus Kusina, 1980, p. 60; North Urals; crowdecotense: Bollandoceras crowdecotense Korn \& Tilsley, 2006, p. 131; Derbyshire; fordi: Bollandoceras fordi Korn \& Tilsley, 2006, p. 127; Derbyshire; furiense: Bollandoceras 

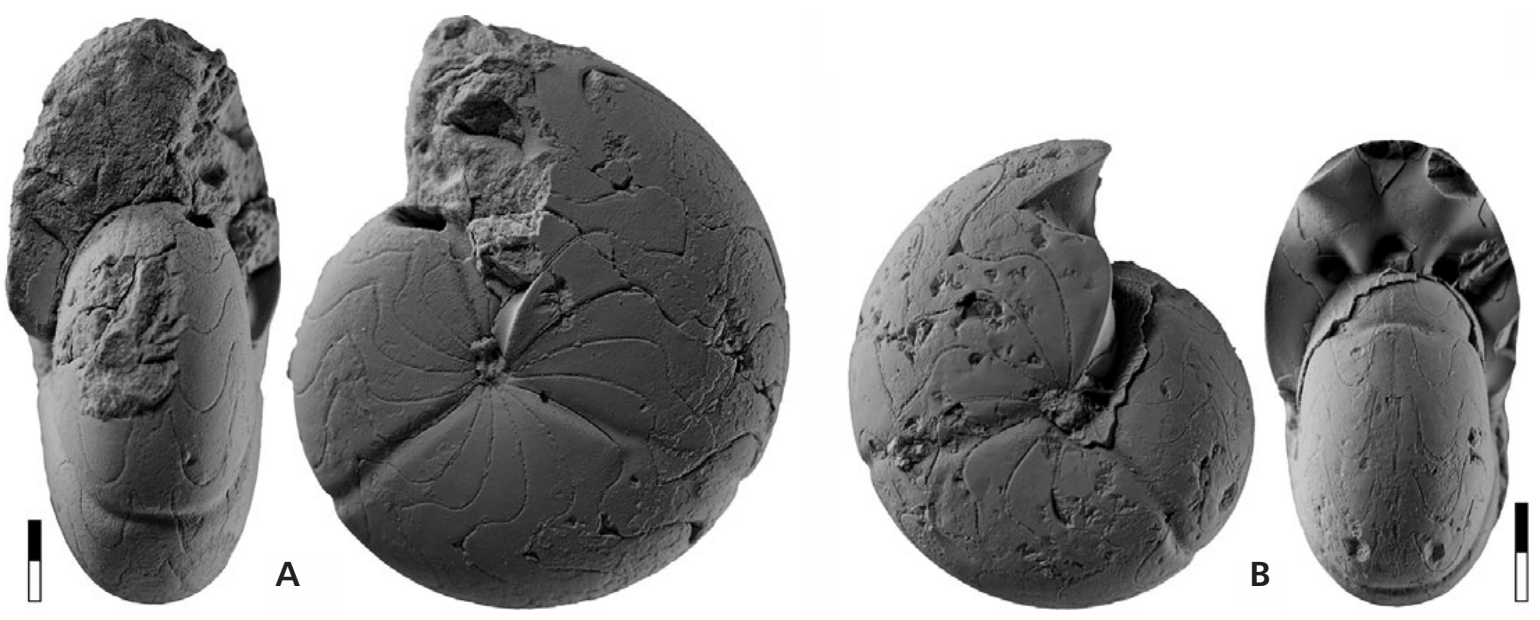

Figure 14. Bollandoceras occidentale sp. nov. from bed 6 (sample 05UTMI-3) of Middle Confusion Range 1. • A - holotype UMNH IP 2630; $\times 4.0$. - B - paratype UMNH IP $2631 ; \times 5.0$.

Table 1. Conch ontogeny (Fig. 15) of Bollandoceras occidentale sp. nov.

\begin{tabular}{|c|c|c|c|}
\hline $\mathrm{dm}$ & conch shape & whorl cross section shape & aperture \\
\hline $2 \mathrm{~mm}$ & $\begin{array}{l}\text { thinly pachyconic; evolute } \\
\text { (ww/dm } \sim 0.60 ; \mathrm{uw} / \mathrm{dm} \sim 0.50 \text { ) }\end{array}$ & $\begin{array}{l}\text { strongly depressed; moderately embracing }(\mathrm{ww} / \mathrm{wh} \sim 2.20 \text {; } \\
\mathrm{IZR} \sim 0.23)\end{array}$ & low $($ WER 1.60) \\
\hline $10 \mathrm{~mm}$ & $\begin{array}{l}\text { thickly discoidal; involute } \\
(\mathrm{ww} / \mathrm{dm}=0.50-0.55 ; \mathrm{uw} / \mathrm{dm}=0.05-0.10)\end{array}$ & $\begin{array}{l}\text { weakly compressed; very strongly embracing }(\mathrm{ww} / \mathrm{wh} \sim 0.95 \\
\mathrm{IZR} \sim 0.55)\end{array}$ & moderate $(\mathrm{WER}=1.75-1.90)$ \\
\hline $25 \mathrm{~mm}$ & $\begin{array}{l}\text { thinly discoidal; involute } \\
\text { (ww/dm } \sim 0.40 ; \text { uw/dm } \sim 0.01 \text { ) }\end{array}$ & $\begin{array}{l}\text { weakly compressed; very strongly embracing (ww/wh } \sim 0.70 \text {; } \\
\mathrm{IZR} \sim 0.55)\end{array}$ & moderate $($ WER 1.80) \\
\hline
\end{tabular}

furiense Padget, 1952, p. 864; Ireland; globosum: Bollandoceras globosum Bisat, 1952, p. 177; Yorkshire; hodderense: Beyrichoceras hodderense Bisat, 1924, p. 84; Lancashire; inopinum: Bollandoceras inopinum Ruzhencev, 1975, p. 39; Verkhoyan; kaindynense: Bollandites? kaindynense Popov, 1968, p. 40; Tien Shan; librovitchi: Beyrichoceras librovitchi Popov, 1968, p. 43; Tien Shan; mackellari: Beyrichoceras mackellari Campbell, Brown \& Coleman, 1983, p. 89; Queensland; micronotoide: Bollandoceras micronotoides Bisat, 1934, p. 290; Yorkshire; micronotum: Goniatites micronotus Phillips, 1836, p. 234; Yorkshire; minusculum: Dzhaprakoceras? minusculum Kusina, 1980, p. 55; North Urals; mirrih: Bollandoceras mirrih Bockwinkel, Korn \& Ebbighausen, 2010, p. 237; Gourara, Algeria; nitens: Bollandoceras nitens Bockwinkel, Korn \& Ebbighausen, 2010, p. 227; Gourara, Algeria; occidentale: Bollandoceras occidentale sp. nov.; Antler Foreland Basin; parvum: Bollandoceras parvum Kusina, 1994, p. 166; Mongolia; politum: Bollandoceras politum Bockwinkel, Korn \& Ebbighausen, 2010, p. 231; Gourara, Algeria; stylense: Bollandoceras stylense Kusina, 1991, p. 40; Donets Basin; subangulare: Bollandoceras subangulare Bockwinkel, Korn \& Ebbighausen, 2010, p. 229; Gourara, Algeria; submicronotum: Bollandoceras submicronotum Bisat, 1934, p. 291; Derbyshire [synonym of B. micronotum]; suursureni: Bollandoceras suursureni $\mathrm{Ku}-$ sina, 1994, p. 167; Mongolia; tianshanicum: Beyrichoceras tianshanicum Popov, 1968, p. 44; Tien Shan; undulatum: Dzhaprakoceras undulatum Riley, 1996, p. 66; Lancashire; westheadi: Dzhaprakoceras westheadi Riley, 1996, p. 66; Lancashire; zuhara: Bollandoceras zuhara Bockwinkel, Korn \& Ebbighausen, 2010, p. 235; Gourara, Algeria.

\section{Bollandoceras occidentale sp. nov.} Figures 14, 15

Derivation of name. - After occidens = the West; because of its occurrence in western North America.

Holotype. - Specimen UMNH IP 2630, illustrated in Fig. 14A.

Type locality and horizon. - Middle Confusion Range 1, bed 10 (sample 05UTMI-3); Camp Canyon Member of Chainman Formation, Calygirtyoceras arcticum Ammonoid Biozone.

Material. - Besides the holotype, four paratypes from the type sample and one from bed 17 (sample 07UTJU-1) of Granite Mountain-South. The size of the specimens ranges from 10 to $25 \mathrm{~mm}$ conch diameter.

Diagnosis. - Species of Bollandoceras with thinly pachyconic conch in juvenile stages (ww/dm 0.60-0.70 up to 

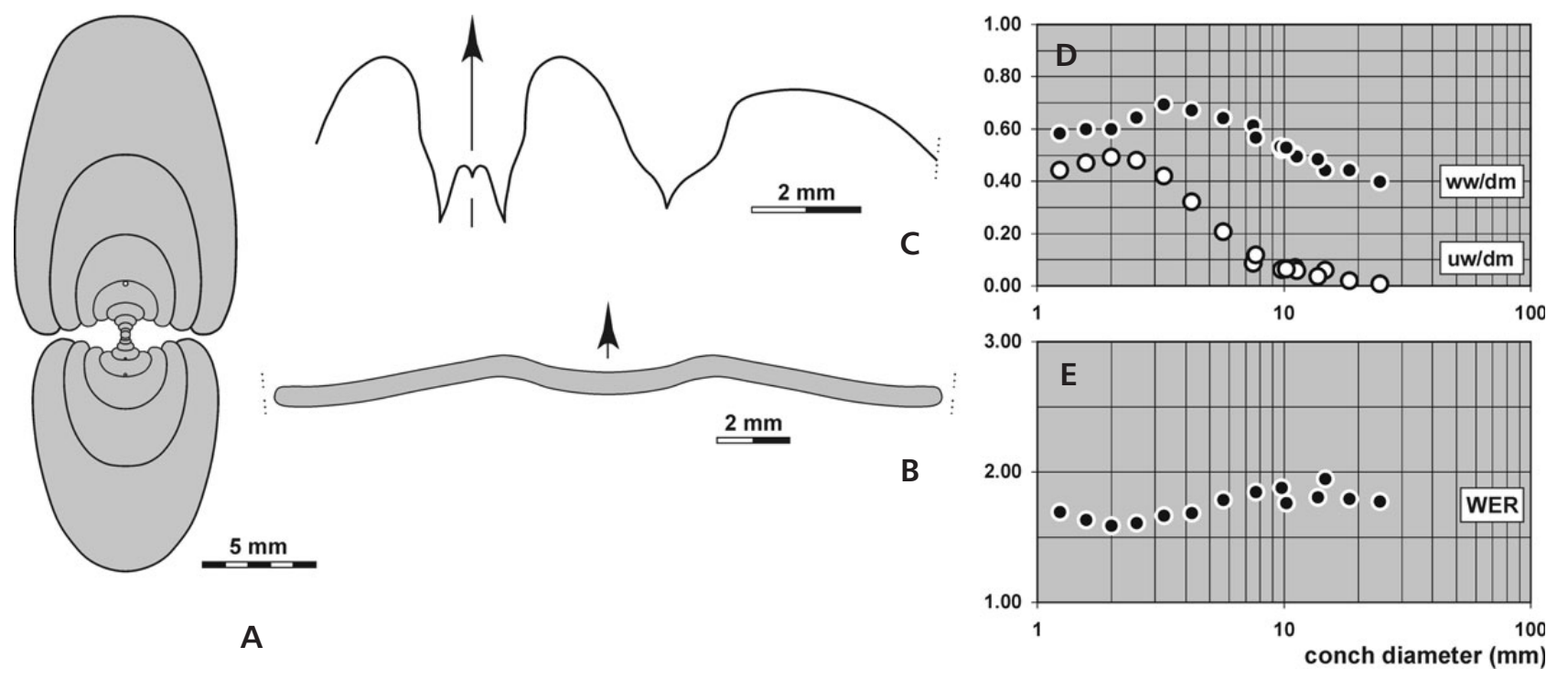

Figure 15. Bollandoceras occidentale sp. nov. from bed 6 (sample 05UTMI-3) of Middle Confusion Range 1 . $\bullet$ A - cross section of paratype UMNH IP $2632 ; \times 2.5$. $\bullet \mathrm{B}-$ constriction course of holotype UMNH IP 2630 , at $13.2 \mathrm{~mm}$ diameter, $6.4 \mathrm{~mm}$ ww, $6.5 \mathrm{~mm}$ wh; $\times 4.0$. $\bullet$ C - suture line of holotype UMNH IP 2630, at $13.6 \mathrm{~mm}$ diameter, $6.6 \mathrm{~mm}$ ww, $6.8 \mathrm{~mm}$ wh; $\times 6.0 . \bullet \mathrm{D}, \mathrm{E}-$ ontogenetic development of the conch width index (ww/dm), umbilical width index (uw/dm), and whorl expansion rate (WER) of all available specimens.

Table 2. Conch dimensions (in $\mathrm{mm}$ ) and proportions for reference specimens of Bollandoceras occidentale sp. nov.

\begin{tabular}{lccccccccccc}
\hline & dm & ww & wh & uw & ah & ww/dm & ww/wh & uw/dm & WER & IZR \\
\hline PT UMNH IP 2632 & 24.5 & 9.8 & 14.0 & 0.2 & 6.1 & 0.40 & 0.70 & 0.01 & 1.78 & 0.56 \\
HT UMNH IP 2630 & 14.7 & 6.5 & 8.2 & 0.9 & 4.2 & 0.44 & 0.80 & 0.06 & 1.95 & 0.49 \\
PT UMNH IP 2635 & 11.3 & 5.6 & 6.3 & 0.7 & - & 0.49 & 0.88 & 0.06 & - \\
PT UMNH IP 2631 & 9.8 & 5.1 & 5.2 & 0.6 & 2.6 & 0.52 & 0.98 & 0.06 & 1.88 & 0.49 \\
\hline
\end{tabular}

$6 \mathrm{~mm}$ diameter); relative conch width decreasing during ontogeny to 0.40 at a diameter of $25 \mathrm{~mm}$. Umbilicus relatively widest at $2-3 \mathrm{~mm}$ diameter (uw/dm $=0.40-0.50$ ), becoming almost closed at $20 \mathrm{~mm}$. Whorl expansion rate low in juveniles (WER 1.60), increasing to more than 1.80 at more than $10 \mathrm{~mm}$ diameter. Ornament of biconvex, very fine growth lines; steinkern with faint, slightly biconvex constrictions. Suture with inflexed, slightly diverging flanks of the external lobe.

Description. - The cross section of paratype UMNH IP 2632 and the morphometric plots demonstrate the conspicuous ontogenetic changes during ontogeny (Fig. 15D, E). The umbilicus is wide in the juvenile stage, reaching a uw/dm ratio of 0.50 at $2 \mathrm{~mm}$ conch diameter. By $15 \mathrm{~mm}$ diameter, the umbilicus is almost closed. The conch width ratio is highest at $3 \mathrm{~mm}$ diameter $(\mathrm{ww} / \mathrm{dm}=0.70)$ and thereafter decreases continuously to a value of 0.40 at $24 \mathrm{~mm}$ diameter. Stages above $6 \mathrm{~mm}$ diameter have a moderately high aperture, resulting in a whorl expansion rate of 1.80-1.95.

Paratype UMNH IP 2632 clearly shows the transformation from widely umbilicate juvenile forms with a ventrally depressed whorl cross section to the narrowly umbilicate adult conch with laterally compressed whorls (Fig. 15A). In all stages during ontogeny, the flanks and umbilical wall are rounded, and the conch is thickest in some distance from the umbilicus. The adult stage shows modification of the venter; it becomes slightly flattened with the outer flanks appearing truncated.

The best-preserved specimen is holotype UMNH IP 2630 (Fig. 14A); it is fully chambered and almost $15 \mathrm{~mm}$ in diameter. It is discoidal ( $\mathrm{ww} / \mathrm{dm}=0.44)$ with an almost closed umbilicus (uw/dm $=0.06$ ) and a moderately high aperture (WER $=1.95)$. The conch is thickest on the flanks, away from the umbilicus, and the venter is narrowly rounded. Shell remains are preserved only in a small area near the aperture; they show extremely fine growth lines. The internal mould has three constrictions standing in irregular distances of less than $120^{\circ}$. They extend in linear course over the flanks, bend forward to form a low ventrolateral projection and then reverse into a moderately deep ventral sinus (Fig. 15B).

The suture line of paratype UMNH IP 2630 is typical for the genus with an external lobe that has sinuous, diverging flanks and a median saddle of one third of the height of 
Figure 16. Entogonites burbankensis sp. nov. $・$ A - holotype UMNH IP 2637 from bed 4 (sample 01UTMI-2) of South Burbank Hills; $\times$ 6.0. - B - paratype UMNH IP 2638 from bed 4 (sample 01UTMI-2) of South Burbank Hills; $\times 6.0$.
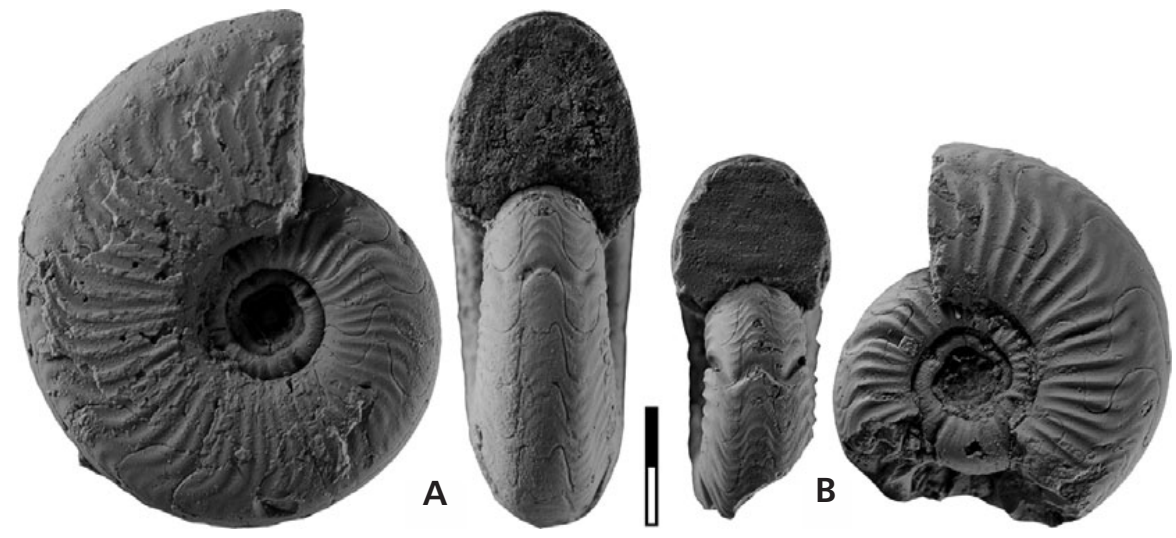

the external lobe depth (Fig. 15C). The ventrolateral saddle is broadly rounded, and the adventive lobe asymmetric with a markedly more sinuous dorsal flank.

Discussion. - Bollandoceras is a rare genus on the American continent. Gordon (1957) reported "Beyrichoceras micronotum" from Kiruktagiak River in Alaska that co-occurs with the genus Goniatites. These specimens resemble B. occidentale in their general form, but differ in the wider external lobe, the lower aperture (WER $=1.70$ at $18 \mathrm{~mm}$ diameter), and the much wider umbilicus (uw/dm =0.07).

Bollandoceras is most diverse in North England, Morocco, Algeria, and the Tien Shan, where a number of species are known (Bisat 1952; Riley 1996; Korn \& Tilsley 2006; Korn et al. 1999, 2007; Bockwinkel et al. 2010; Popov 1968). All of the species from these regions, however, differ from $B$. occidentale by having wider umbilici (uw/dm larger than 0.10 ) at $20 \mathrm{~mm}$ conch diameter and higher apertures. The most common species from North England, Bollandoceras micronotum (Phillips, 1836), for instance, has at $20 \mathrm{~mm}$ conch diameter, an umbilical width of 0.10 , and a whorl expansion rate over 2.00 .

Family Entogonitidae Ruzhencev \& Bogoslovskaya, 1971

Family definition. - Pericyclaceae with strong radial ornament consisting of sharp ribs, which frequently dichotomize. Inner whorls usually tetrangularly coiled.

Included genera. - Entogonites Kittl, 1904; Tetragonites Kittl, 1904 [homonym of Tetragonites Kossmat, 1895; synonym of Entogonites Kittl, 1904]; Kittliella Frech, 1906 [synonym of Entogonites Kittl, 1904]; Ubites Korn \& Sudar, 2010.

Discussion. - Entogonites is still an enigmatic genus and its phylogenetic relationships are not solved. Traditionally, the genus has been placed phylogenetically near Nomismoceras based on its thinly discoidal, relatively widely umbilicate conch, ornament with high ventrolateral projection, and rounded adventive lobe of the suture line (e.g. Ruzhencev \& Bogoslovskaya 1971).

The new Družetić (north-western Serbia) genus Ubites Korn and Sudar 2010 possesses Entogonites-like ornament, but an evolute ribbed juvenile stage and later closure of the umbilicus (similar to Bollandites). This strongly suggests that Entogonites is more closely connected phylogenetically to other Early Carboniferous ammonoids such as pericylids, girtyoceratids, or Bollandites, rather than Nomismoceras (Korn \& Sudar in Korn et al., 2010). The family Entogonitidae is therefore placed in the superfamily Pericyclaceae.

\section{Genus Entogonites Kittl, 1904}

Type species. - Tetragonites Grimmeri Kittl, 1904 (by monotypy).

Genus definition. - As for the family.

Included species. - acus: Entogonites acus sp. nov.; Antler Foreland Basin; borealis: Entogonites borealis Gordon, 1957, p. 53; Alaska; burbankensis: Entogonites burbankensis sp. nov.; Antler Foreland Basin; grimmeri: Tetragonites Grimmeri Kittl, 1904, p. 677; Bosnia; nasutus: Pericyclus nasutus Schmidt, 1941, p. 151; Harz; saharensis: Entogonites saharensis Korn, Klug \& Mapes, 2005, p. 363; Anti-Atlas; tetragonus: Branneroceratoides tetragonus Kullmann, 1962, p. 88; Serbia.

\section{Entogonites burbankensis sp. nov.} Figures 16, 17A

Derivation of name. - After the South Burbank Hills, the type locality.

Holotype. - Specimen UMNH IP 2637, illustrated in Fig. 16A. 
Table 3. Conch dimensions (in $\mathrm{mm}$ ) and proportions for reference specimens of Entogonites burbankensis sp. nov.

\begin{tabular}{llllllllcccccc}
\hline & $\mathrm{dm}$ & ww & wh & uw & ah & ww/dm & ww/wh & uw/dm & WER & IZR \\
\hline HT UMNH IP 2637 & 8.7 & 3.3 & 3.9 & 2.5 & 2.8 & 0.38 & 0.83 & 0.28 & 2.18 & 0.29 \\
PT UMNH IP 2638 & 7.3 & 3.1 & 3.7 & 2.0 & 2.3 & 0.42 & 0.84 & 0.28 & 2.12 & 0.38 \\
PT UMNH IP 2639 & 6.2 & 2.7 & 2.9 & 2.0 & - & 0.43 & 0.93 & 0.32 & - & - \\
\hline
\end{tabular}
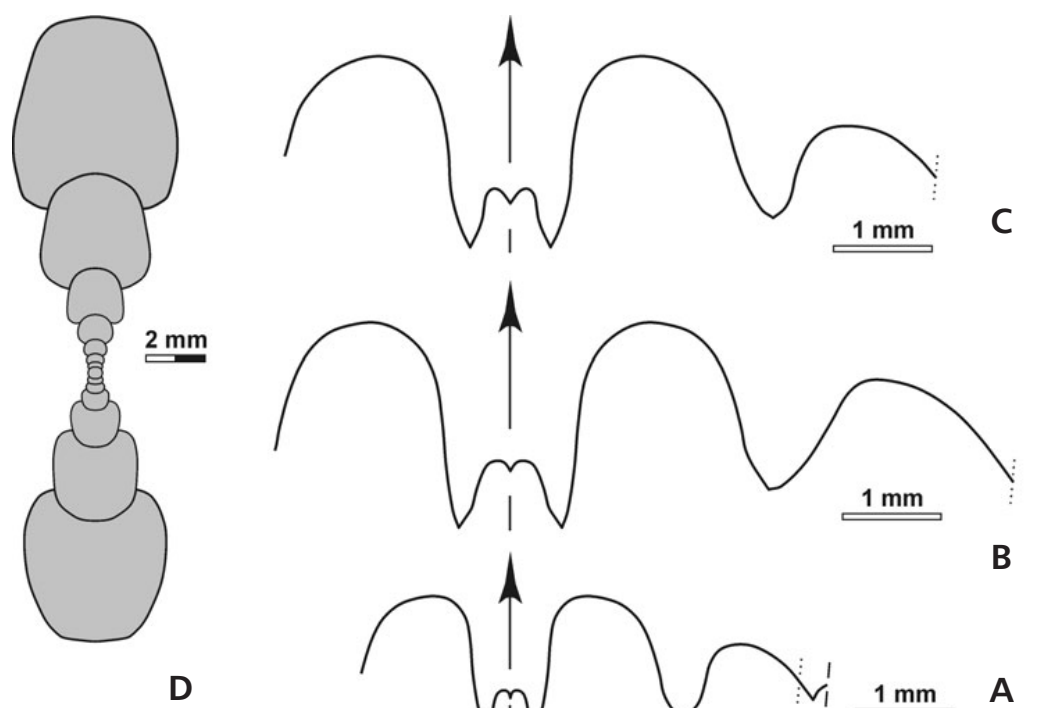

D

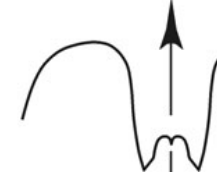

B

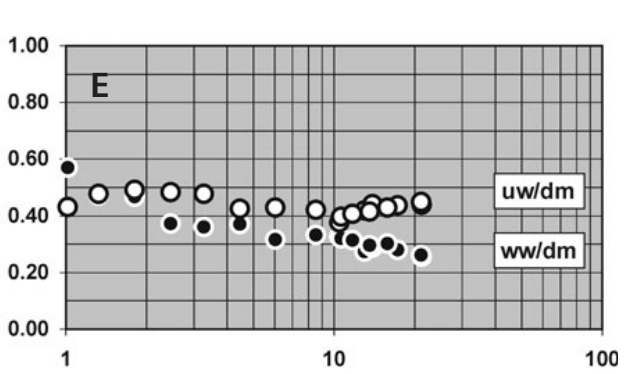

Figure 17. Species of Entogonites. • A - Entogonites burbankensis sp. nov., suture line of paratype UMNH IP 2638 from bed 4 (sample 01 UTMI-2) of South Burbank Hills, at $6.3 \mathrm{~mm}$ diameter, $2.8 \mathrm{~mm}$ ww, $3.2 \mathrm{~mm}$ wh; $\times 10$. $\bullet$ B - Entogonites borealis Gordon, 1957, suture line of specimen UMNH IP 2642 from bed 7 (sample 93UTMI-25) of Jensen Wash, at $4.5 \mathrm{~mm}$ ww, $4.6 \mathrm{~mm}$ wh; $\times 10$. $\bullet \mathrm{C}-$ Entogonites acus sp. nov., suture line of holotype UMNH IP 2658 from a single bullion of South Needle Range, at $3.5 \mathrm{~mm}$ diameter, $3.9 \mathrm{~mm}$ ww, $3.2 \mathrm{~mm}$ wh; $\times 10$. $\bullet$ D - Entogonites acus sp. nov., cross section of paratype UMNH IP 2662 from bed 8 (sample 07UTMI-6) of South Burbank Hills; $\times 3 . \bullet$ E, F - Entogonites acus sp. nov., ontogenetic development of the conch width index (ww/dm), umbilical width index (uw/dm), and whorl expansion rate (WER) of all available specimens.

Type locality and horizon. - South Burbank Hills, bed 4; Camp Canyon Member of Chainman Formation, Calygirtyoceras arcticum Biozone.

Material. - The holotype and three paratypes; conch diameter up to $9 \mathrm{~mm}$.

Diagnosis. - Species with a thinly discoidal conch (ww/dm $=0.35-0.40$ ), moderate umbilicus (uw/dm $=0.28-0.32$ ) and narrowly rounded venter at $8 \mathrm{~mm}$ conch diameter. Aperture moderately high (WER $=2.10-2.20)$. Inner whorls with weak tetrangular coiling. Shell ornament of weak, rounded and ventrolaterally dichotomising ribs. Ventrolateral projection of ribs moderately high, ventral sinus deep. Suture line with asymmetric ventrolateral saddle.

Description. - Of the well-preserved material, holotype UMNH IP 2637 is the largest at slightly less than $9 \mathrm{~mm}$ diameter (Fig. 16A). The shape is discoidal $(\mathrm{ww} / \mathrm{dm}=$ 0.38 ), with a moderate umbilicus (uw/dm $=0.28$ ), and a moderately high aperture (WER $=2.18$ ). The whorl cross section is laterally compressed with a rounded umbilical margin and a narrowly rounded venter. The inner whorls can be seen through the umbilicus and are weakly tetrangular. The ornament is dominated by approximately 45 prominent ribs on the last volution. These extend radially across the flanks and bend forward to form a moderately high ventrolateral projection and inflex into a deep ventral sinus. The ribs dichotomize in the ventrolateral area, becoming weaker across the venter. A single constriction of the internal mould can be seen at the beginning of the last whorl; it is particularly deep on the venter and follows the course of the ribs.

Paratype UMNH IP 2638 is little more than $6 \mathrm{~mm}$ in diameter and has a morphology very similar to the holotype. It has only 35 ribs, which are sharp and dichotomize in the ventrolateral area. The ventral sinus of the ribs is chevron-shaped in this specimen. The specimen has two steinkern constrictions on the first half of the last whorl (Fig. 16B).

The suture line of paratype UMNH IP 2638 has, at 6 $\mathrm{mm}$ conch diameter, an external lobe with slightly curved, subparallel and weakly diverging flanks and a median saddle of about one quarter height of the external lobe depth (Fig. 17A). The broadly rounded ventrolateral saddle is asymmetric with a steep external and an oblique lateral 
Figure 18. Entogonites borealis Gordon, 1957 from bed 7 (sample 93UTMI-25) of Jensen Wash. $\bullet$ A - specimen UMNH IP $2644 ; \times 3.0$. $\bullet$ B - specimen UMNH IP $2645 ; \times 3.0$.
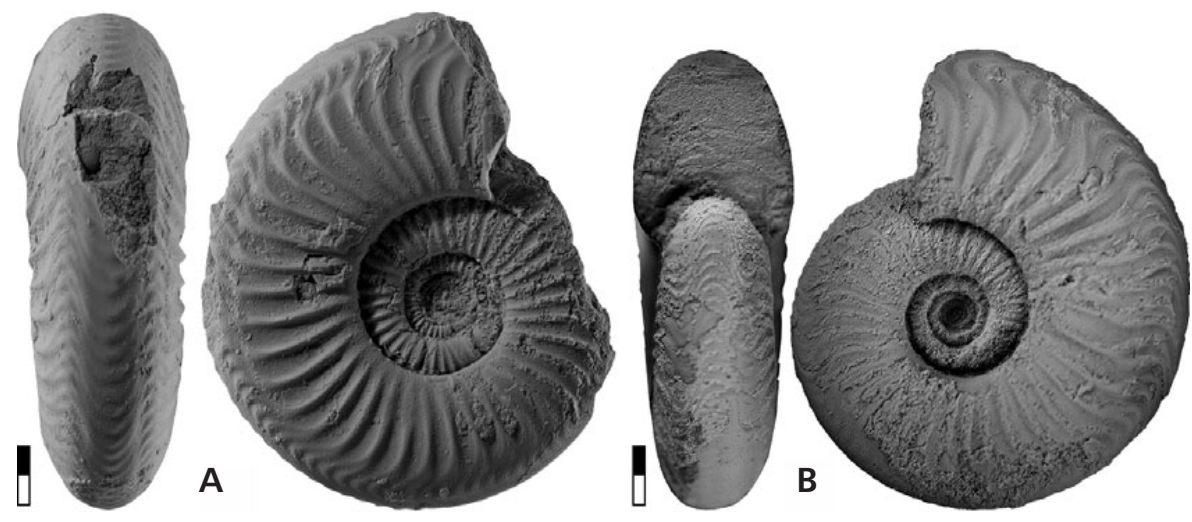

Table 4. Conch dimensions (in $\mathrm{mm}$ ) and proportions for reference specimens of Entogonites borealis Gordon, 1957.

\begin{tabular}{|c|c|c|c|c|c|c|c|c|c|c|}
\hline & $\mathrm{dm}$ & ww & wh & uw & ah & $\mathrm{ww} / \mathrm{dm}$ & ww/wh & $\mathrm{uw} / \mathrm{dm}$ & WER & IZR \\
\hline PT UMNH IP 2644 & 16.7 & 5.8 & 6.3 & 5.9 & 4.8 & 0.35 & 0.92 & 0.35 & 1.97 & 0.24 \\
\hline HT UMNH IP 2645 & 15.7 & 5.5 & 5.8 & 5.2 & 4.3 & 0.35 & 0.95 & 0.33 & 1.87 & 0.27 \\
\hline PT UMNH IP 2642 & 14.1 & 5.4 & 5.4 & 5.0 & - & 0.39 & 1.01 & 0.35 & - & - \\
\hline PT UMNH IP 2646 & 12.0 & 4.1 & 4.0 & 4.1 & 3.2 & 0.34 & 1.02 & 0.34 & 1.84 & 0.21 \\
\hline
\end{tabular}

flank, the latter belonging to a small, slightly asymmetric adventive lobe.

Discussion. - Entogonites nasutus and E. borealis have narrow umbilici and are close to E. burbankensis. Both are, however, more widely umbilicate than E. burbankensis; their uw/dm ratio is about 0.35 (measured in the holotype of E. borealis), in contrast to E. burbankensis, where, at $7-8 \mathrm{~mm}$ conch diameter, the uw/dm ratio is around 0.30 . Furthermore, the ribs of E. burbankensis show a much more pronounced ventrolateral projection than E. nasutus and E. borealis.

\section{Entogonites borealis Gordon, 1957}

Figures 17B, 18

1957 Entogonites borealis Gordon, p. 53, pl. 6, figs 37-40.

Holotype. - Specimen USNM 118981, illustrated by Gordon (1957) on pl. 6, figs 37-40.

Type locality and horizon. - USGS locality 10864, Kiruktagiak River (Brooks Range); Kuna Formation, probably Calygirtyoceras arcticum Biozone.

Material. - Fourteen specimens; conch diameter up to $17 \mathrm{~mm}$.

Diagnosis. - Entogonites with thinly discoidal conchs (ww/dm $=0.35-0.40)$ and moderately wide umbilici (uw/dm $=0.30-0.35)$ at $12-17 \mathrm{~mm}$ conch diameter. Aper- ture moderately high in the adult stage (WER $=1.85-2.00$ ). Inner whorls with very weak tetrangular coiling. Shell ornament with weak, sharp, ventrolaterally-dichotomizing ribs. Ventrolateral projection of ribs high, ventral sinus deep. Suture line with symmetric ventrolateral saddle.

Description. - Specimen UMNH IP 2645 is a wellpreserved steinkern nearly $16 \mathrm{~mm}$ in diameter (Fig. 18A). It is thinly discoidal ( $\mathrm{ww} / \mathrm{dm}=0.35$ ) with a moderately wide umbilicus ( $\mathrm{uw} / \mathrm{dm}=0.33$ ). The inner whorls show a very weak tetrangular coiling. The last whorl possesses 36 sharp ribs, which regularly bifurcate in the outer flank area. The dichotomizing ribs extend almost straight across the flanks, and it is particularly the apertural of the two branches that forms a ventrolateral projection. The ventral sinus of the ribs is deep.

A slightly larger specimen, UMNH IP 2644 (17 mm diameter), is similar, having the same weakly developed tetrangular coiling of the inner whorls and umbilical width ratio $(\mathrm{uw} / \mathrm{dm}=0.35)$. It has nearly 40 ribs, which show, on the first half of the last volution, a moderately high ventrolateral projection (Fig. 18B). At the largest preserved diameter, this projection is almost as high as in the larger specimen UMNH IP 2654.

The suture line was drawn from specimen UMNH IP 2642 at approximately $11 \mathrm{~mm}$ diameter (Fig. 17B). It is characteristic for the genus with an almost parallel-sided external lobe, a broadly rounded ventrolateral saddle, and a small, almost symmetric, V-shaped adventive lobe.

Discussion. - Entogonites nasutus (Schmidt, 1941) is similar in conch proportions and degree of tetrangular coiling, 


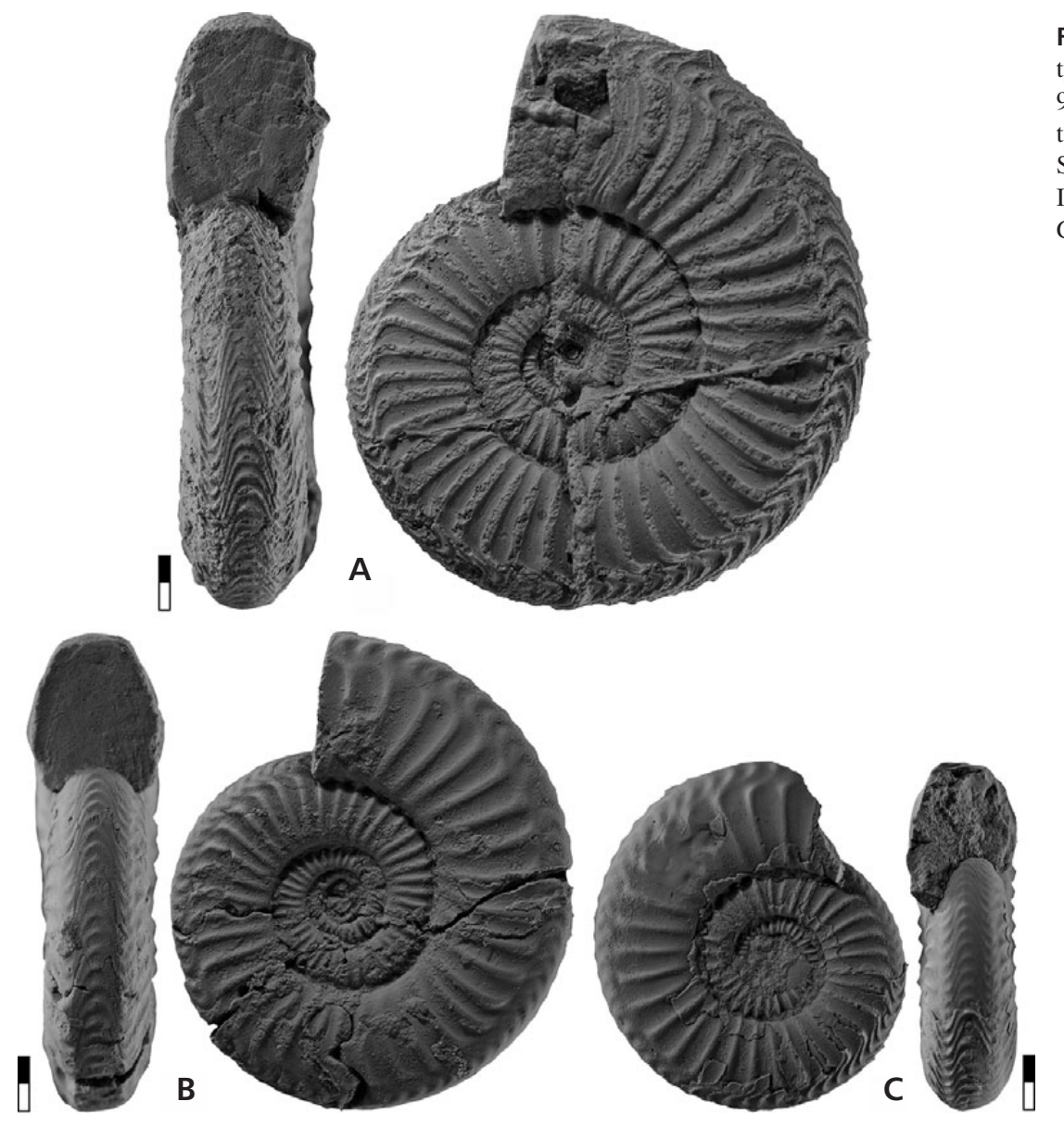

Figure 19. Entogonites acus sp. nov. $\bullet$ A - paratype UMNH IP 2654 from bed 13 (sample 97UTMI-12) of Jensen Wash; × 3.0. • B - holotype UMNH IP 2658 from a single bullion of South Needle Range; $\times 3.0 . \bullet \mathrm{C}-$ paratype UMNH IP 2655 from bed 25 (sample 05UTJU-12) of Granite Mountain South; $\times 3.0$.

but has a much lower, more broadly rounded ventrolateral projection of the ribs. E. grimmeri (Kittl, 1904) and E. saharensis Korn, Klug \& Mapes, 1999 have a similar conch and rib morphology, but possess conspicuous tetrangular coiling of the inner whorls. E. acus from the Chainman Formation has a wider umbilicus (uw/dm $=0.40-0.45$ ) and a flattened venter, it is thus clearly separated from E. borealis.

\section{Entogonites acus sp. nov.}

Figures 17C-F, 19

Derivation of name. - After Lat. acus = needle, reference to the type locality.

Holotype. - Specimen UMNH IP 2658, illustrated in Fig. 19A.

Type locality and horizon. - Needle Range, single bullion (07UTMI-10); Camp Canyon Member of Chainman Formation, probably Girtyoceras primum Biozone.

Material. - The holotype and eight paratypes; conch diameter up to $22 \mathrm{~mm}$.
Diagnosis. - Species of Entogonites with a thinly discoidal conch $(\mathrm{ww} / \mathrm{dm}=0.25-0.30)$, moderately wide umbilicus (uw/dm $=0.40-0.45$ ) at 12-22 mm conch diameter, and a slightly flattened venter. Aperture moderately high (WER $=1.75-1.90$ ). Inner whorls with very weak tetrangular coiling. Shell ornament with weak, sharp and ventrolaterally dichotomising ribs. Ventrolateral projection of ribs high, ventral sinus deep. Suture line with asymmetric ventrolateral saddle.

Description. - The cross section of paratype UMNH IP 2662 displays the minor ontogenetic changes in conch proportions; the ww/dm ratio decreases from 0.57 at $1 \mathrm{~mm}$ diameter to 0.26 at $21 \mathrm{~mm}$, the uw/dm ratio ranges between 0.40 and 0.45 throughout ontogeny, and the whorl expansion rate is between 1.70 and 2.00 (Fig. 17D). More conspicuous are the changes in the shape of the whorl cross section. They are circular up to $3 \mathrm{~mm}$ conch diameter, then becoming laterally compressed, and followed by the adult stage (above $12 \mathrm{~mm}$ diameter), in which the flanks and, on the last volution, also the venter become flattened.

The largest specimen is paratype UMNH IP 2654; it measures nearly $22 \mathrm{~mm}$ and is slightly deformed by a calcite-filled fissure. It is almost entirely testiferous 
Table 5. Conch dimensions (in $\mathrm{mm}$ ) and proportions for reference specimens of Entogonites acus sp. nov.

\begin{tabular}{lcccccccccccc}
\hline & $\mathrm{dm}$ & ww & wh & uw & ah & ww/dm & ww/wh & uw/dm & WER & IZR \\
\hline PT UMNH IP 2654 & 21.7 & 5.5 & 6.9 & 9.6 & 5.5 & 0.25 & 0.80 & 0.44 & 1.79 & 0.21 \\
HT UMNH IP 2657 & 21.2 & 5.4 & 7.2 & 9.3 & 5.6 & 0.26 & 0.76 & 0.44 & 1.86 & 0.21 \\
PT UMNH IP 2662 & 21.1 & 5.5 & 6.5 & 9.5 & 5.3 & 0.26 & 0.85 & 0.45 & 1.78 & 0.18 \\
PT UMNH IP 2658 & 17.2 & 4.8 & 5.5 & 7.5 & 4.6 & 0.28 & 0.87 & 0.44 & 1.85 & 0.17 \\
PT UMNH IP 2656 & 13.9 & 4.0 & 4.7 & 6.2 & 3.8 & 0.29 & 0.86 & 0.44 & 1.88 & 0.20 \\
PT UMNH IP 2655 & 13.0 & 3.6 & 4.5 & 5.4 & 3.5 & 0.27 & 0.78 & 0.42 & 1.89 & 0.22 \\
\hline
\end{tabular}

(Fig. 18A). The conch is lenticular $(\mathrm{ww} / \mathrm{dm}=0.25)$ with a moderately wide umbilicus $(\mathrm{uw} / \mathrm{dm}=0.44)$ and a rather low aperture $(\mathrm{WER}=1.79)$. The flanks are slightly flattened and converge slowly towards the rounded venter. The umbilical wall is oblique, and the umbilical margin rounded. The inner whorls are not well-preserved in the specimen, but they show that only very weak tetrangular coiling is present. About 40 sharp ribs can be counted on the last volution; these ribs have regular distances, and only in a small zone at the end of growth, crowding of some weaker ribs can be seen. The ribs extend from the umbilicus slightly rursiradiate and pass over the flanks almost rectilinearly. In the ventrolateral position, they turn almost rectangularly forward to form a prominent, narrow projection, and regularly dichotomize. On the venter, they form a sinus twice as deep as the height of the ventrolateral salient; this sinus is very narrow and chevron-shaped.

The holotype (UMNH IP 2658) is the best-preserved individual (Fig. 19A). It has a diameter of $17 \mathrm{~mm}$ and is thinly discoidal $(\mathrm{ww} / \mathrm{dm}=0.28)$, with a moderately wide umbilicus (uw/dm $=0.44$ ) and a rather low aperture $($ WER $=1.85$ ). The flanks are convexly rounded and separated from the flat venter by a distinct ventrolateral margin. At least two of the inner whorls show tetrangular coiling. The ornament of the last volution consists of 35 sharp ribs. These extend slightly retrosiradiate across the flanks and turn on the outer flank forward to form a narrow and high salient. The ventral sinus is deep and subangular. Rib splitting is regular and occurs at the beginning of the ventrolateral projection.

A larger paratype, UMNH IP 2654 (22 mm diameter; Fig. 19A), as well as the smaller specimens UMNH IP 2656 (14 mm diameter) and UMNH IP 2655 (13 mm diameter) closely resemble the conch morphology of the holotype.

The suture line of the holotype (UMNH IP 2658) has an external lobe with subparallel, slightly curved flanks and a median saddle of about 25 per cent of the external lobe depth (Fig. 17C). The ventrolateral saddle is slightly asymmetric and broadly rounded, and the small adventive lobe is V-shaped.

Discussion. - E. acus has a flat venter and thus can be rea- dily differentiated from most other species of Entogonites. In addition to the ventral morphology, E. acus also has a wider umbilicus than the other two Chainman Formation species (uw/dm $=0.40-0.45$ in E. acus, 0.35 in E. borealis, $0.28-0.32$ in E. burbankensis). A paratype of E. borealis figured by Gordon (1957, pl. 6, figs 34-36) is in its conch shape similar to E. acus. However, the Alaskan specimen is a $13 \mathrm{~mm}$ diameter internal mould with a wide umbilicus (uw/dm = 0.53) and strong constrictions and can thus be excluded from $E$. acus (uw/dm $=0.42$ at $13 \mathrm{~mm}$ diameter). It may represent a new species.

\section{Superfamily Girtyocerataceae Wedekind, 1918}

Included families. - Girtyoceratidae Wedekind, 1918; Baschkiritidae Ruzhencev, 1960.

\section{Family Girtyoceratidae Wedekind, 1918}

Family definition. - Girtyocerataceae with ontogenetically changing conch shape; inner whorls evolute, umbilicus closing during ontogeny, adult stage often discoidal and oxyconic. Ornament with biconvex growth lines. Suture line with V-shaped external lobe and rounded ventrolateral saddle; adventive lobe $\mathrm{V}$-shaped with slightly sinuous flanks.

Included genera. - Calygirtyoceras Korn, Klug \& Mapes, 1999; Cousteauceras Korn, 1988; Edmooroceras Elias, 1956; Eumorphoceras Girty, 1909; Girtyoceras Wedekind, 1918; Peytonoceras Saunders, 1966; Sulcogirtyoceras Ruzhencev, 1960; Sundernites Korn, 1993; Torulites Kusina \& Yatskov, 1987; Tumulites McCaleb, Quinn \& Furnish, 1964; Zhongningoceras Yang, 1986; Adelphoceras Girty, 1909 [non Adelphoceras Barrande, 1870; synonym of Girtyoceras Wedekind, 1918]; Dryochoceras Morgan, 1924; [synonym of Girtyoceras Wedekind, 1918]; Jeminayceras Wang, 1983 [synonym of Girtyoceras Wedekind, 1918]; Medioloboceras Kullmann, 1962 [synonym of Eumorphoceras Girty, 1909]; Sagittoceras Hind, 1918 [synonym of Girtyoceras Wedekind, 1918]. 

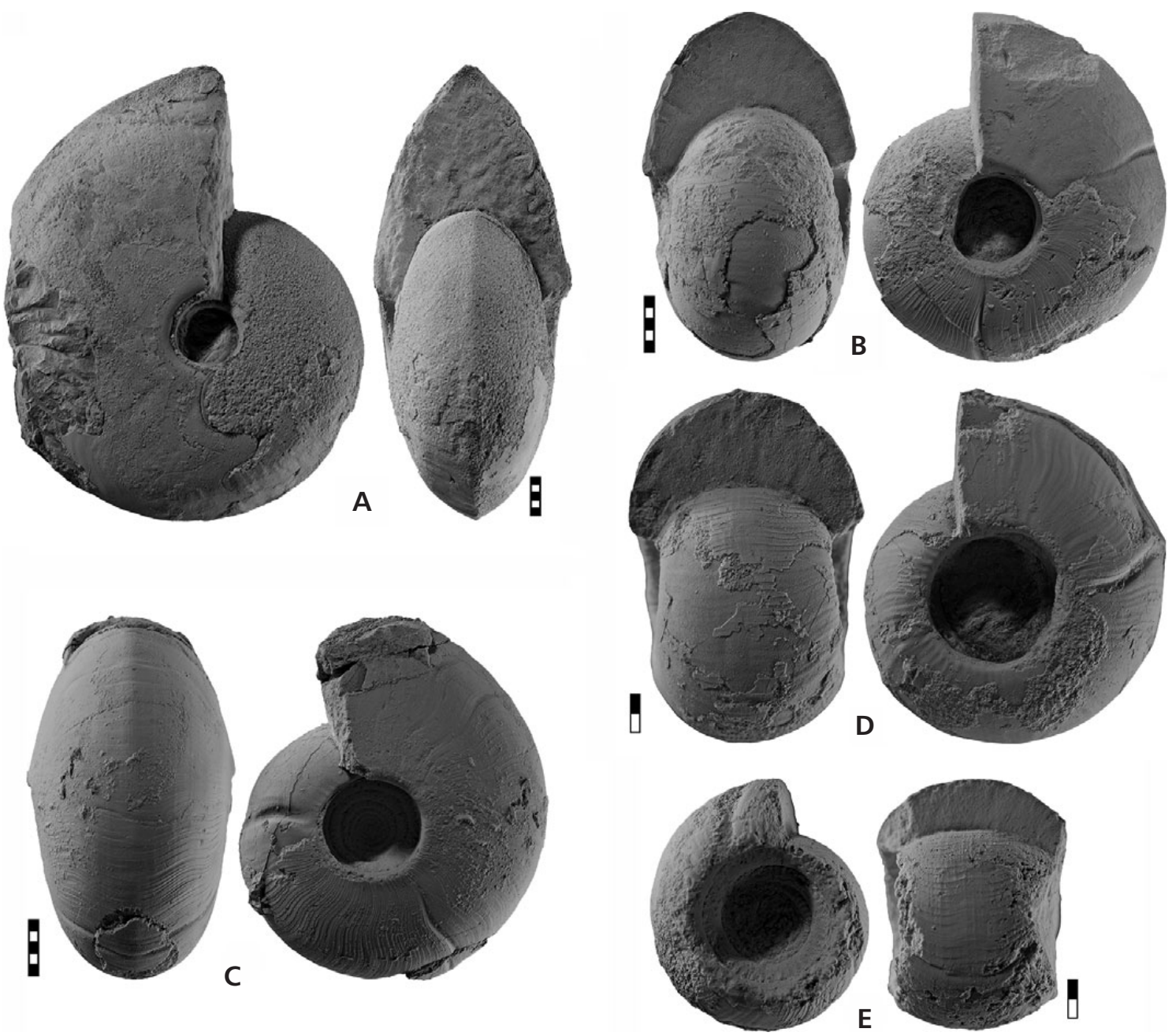

Figure 20. Calygirtyoceras confusionense sp. nov. • A - holotype MB.C.12001.1 from bed 9 of Middle Confusion Range 2; $\times 1.0$. $\bullet$ B - paratype MB.C.12001.2 from bed 9 of Middle Confusion Range 2; $\times 1.5$. $\bullet$ C paratype UMNH IP 2692 from bed 17 (sample 94UTJU-1) of Granite Mountain South; $\times 1.5$. $\bullet$ D - paratype UMNH IP 2690 from bed 7 (sample 93UTMI-25) of Jensen Wash; $\times 2.5$. $\bullet$ E - paratype UMNH IP 2689 from bed 7 (sample 93UTMI-25) of Jensen Wash; $\times 2.5$.

\section{Genus Calygirtyoceras Korn, Klug \& Mapes, 1999}

Type species. - Calygirtyoceras darkaouaense Korn, Klug \& Mapes, 1999 (original designation).

Genus definition. - Girtyoceratidae with moderately large conch that during ontogeny passes through very different morphological stages: early juveniles are widely umbilicate with trapezoidal whorl cross sections, later barrel-shaped with a sharp umbilical margin; intermediate stage with rounded flanks and venter; adult stage lenticular-oxyconic. Lacks ventrolateral grooves. Suture line with V-shaped external lobe, moderately high median saddle, broadly rounded ventrolateral saddle, and V-shaped adventive lobe.

Included species. - arcticum: Girtyoceras arcticum Gordon, 1957, p. 50; Alaska; confusionense: Calygirtyoceras confusionense sp. nov.; Antler Foreland Basin; darkaouaense: Calygirtyoceras darkaouaense Korn, Klug \& Mapes, 1999, p. 354; Anti-Atlas; moorei: Girtyoceras moorei Nicolaus, 1963, p. 118; Rhenish Mountains; platyforme: Girtyoceras platyforme Moore, 1946, p. 403; Yorkshire; zrigatense: Calygirtyoceras zrigatense Korn \& Ebbighausen, 2006, p. 16; Anti-Atlas.

\section{Calygirtyoceras confusionense sp. nov.}

Figures 20, 21

Derivation of name. - After the Confusion range, type region of the species.

Holotype. - Specimen MB.C.12001.1, illustrated in Fig. 20A. 

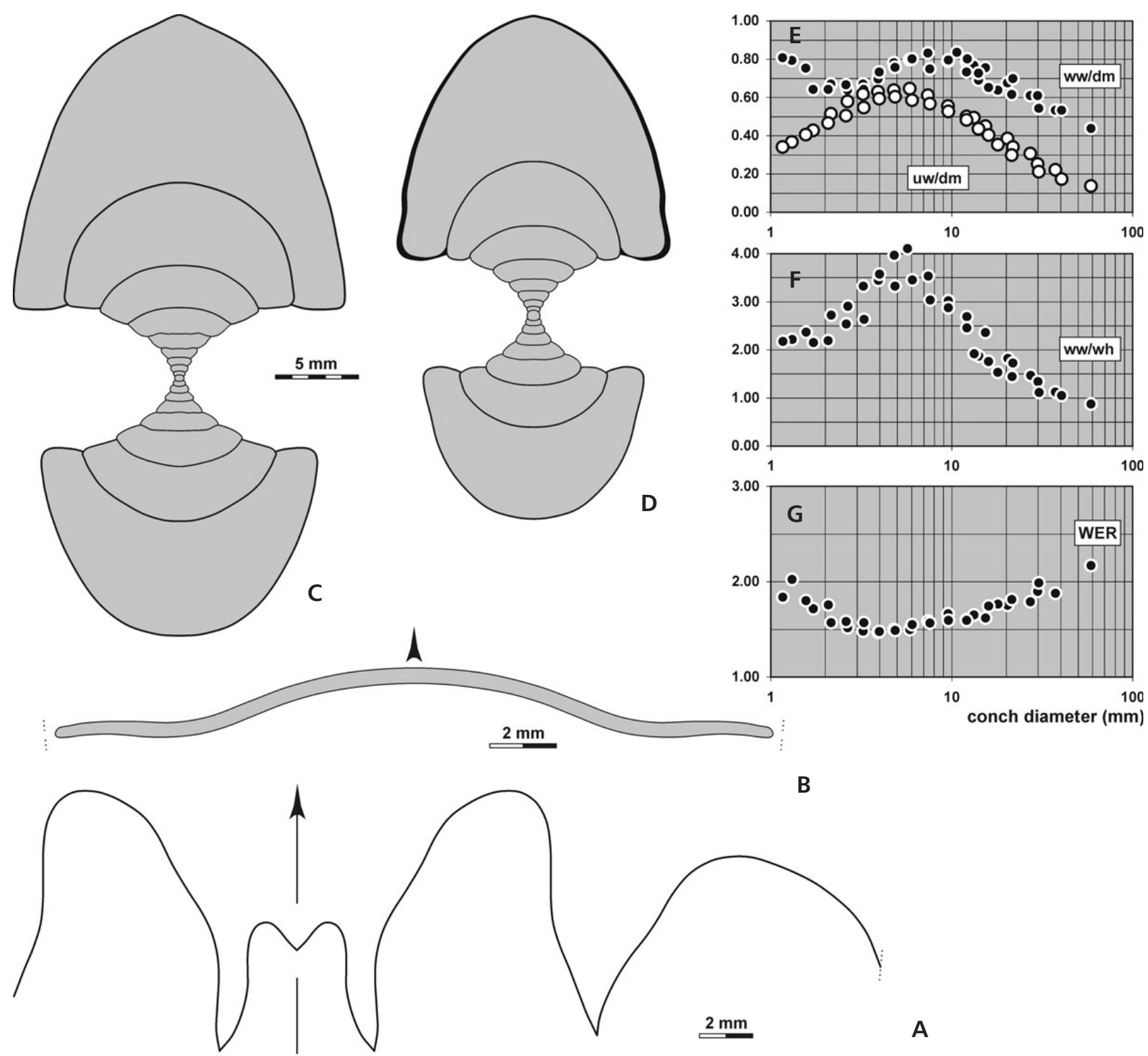

A

Figure 21. Calygirtyoceras confusionense sp. nov. $・$ A - suture line of holotype MB.C.12001.1 from bed 9 of Middle Confusion Range 2, at 40.0 mm diameter, $21.9 \mathrm{~mm}$ ww, $18.5 \mathrm{~mm}$ wh; $\times 4.0$. B - constriction course of paratype MB.C.12001.2 from bed 9 of Middle Confusion Range 2, at 22.0 mm diameter, $16.2 \mathrm{~mm}$ ww, $8.7 \mathrm{~mm}$ wh; $\times 5.0 . \bullet \mathrm{C}-$ cross section of paratype MB.C. 12000 from bed 6 of Middle Confusion Range $1 ; \times 2.5$. $\bullet$ D - cross section of paratype UMNH IP 2693 from bed 17 (sample 94UTJU-1) of Granite Mountain South; $\times 2.5$. $\bullet$ E-G - ontogenetic development of the conch width index (ww/dm), umbilical width index (uw/dm), whorl width index (ww/wh), and whorl expansion rate (WER) of all available specimens.

Type locality and horizon. - Middle Confusion Range 2, bed 9; Camp Canyon Member of Chainman Formation, Calygirtyoceras confusionense Biozone.

Material. - The holotype and 38 paratypes; conch diameter up to $59 \mathrm{~mm}$.

Diagnosis. - Species of Calygirtyoceras with a thickly pachyconic, widely umbilicate conch at 6-8 $\mathrm{mm}$ diameter $(\mathrm{ww} / \mathrm{dm}=0.80 ; \mathrm{uw} / \mathrm{dm}=0.60-0.65)$, a thinly pachyconic, moderately umbilicate conch at $20 \mathrm{~mm}$ diameter $(\mathrm{ww} / \mathrm{dm}=$
$0.60-0.70 ; \mathrm{uw} / \mathrm{dm}=0.35-0.40)$, and a discoidal, narrowly umbilicate conch at 50-60 $\mathrm{mm}$ diameter $(\mathrm{ww} / \mathrm{dm}=0.45$; $\mathrm{uw} / \mathrm{dm}=0.15)$. Whorl cross section with conspicuous ontogenetic changes, crescent-shaped in the early juveniles, later subtrapezoidal with pronounced ventrolateral margin and flat or concave venter (2-6 mm diameter), followed by an intermediate stage with rounded venter and angular umbilical margin (10-20 mm diameter), a preadult stage with laterally compressed whorls and a tectiform venter (30-40 mm diameter), and an adult oxyconic stage (50 mm diameter). Ornamented with lamellose prorsiradiate 
Table 6. Conch ontogeny (Fig. 21) of Calygirtyoceras confusionense sp. nov.

\begin{tabular}{|c|c|c|c|}
\hline $\mathrm{dm}$ & conch shape & whorl cross section shape & aperture \\
\hline $1.5 \mathrm{~mm}$ & $\begin{array}{l}\text { thickly pachyconic; subevolute } \\
\text { (ww/dm } \sim 0.75 ; \text { uw/dm } \sim 0.40 \text { ) }\end{array}$ & $\begin{array}{l}\text { strongly depressed; moderately embracing }(\mathrm{ww} / \mathrm{wh} \sim 2.35 \\
\mathrm{IZR} \sim 0.20)\end{array}$ & moderate $($ WER $\sim 1.80)$ \\
\hline $5 \mathrm{~mm}$ & $\begin{array}{l}\text { thickly pachyconic; very evolute } \\
(\mathrm{ww} / \mathrm{dm}=0.75-0.80 ; \mathrm{uw} / \mathrm{dm}=0.60-0.65)\end{array}$ & $\begin{array}{l}\text { extremely depressed; moderately embracing }(w w / w h=3.50-4.00 \\
\text { IZR } ~ 0.15)\end{array}$ & low $($ WER 1.50) \\
\hline $10 \mathrm{~mm}$ & $\begin{array}{l}\text { thickly pachyconic; evolute } \\
(\mathrm{ww} / \mathrm{dm}=0.80-0.85 ; \mathrm{uw} / \mathrm{dm}=0.50-0.55)\end{array}$ & $\begin{array}{l}\text { extremely depressed; moderately embracing }(\mathrm{ww} / \mathrm{wh}=2.80-3.00 \\
\mathrm{IZR} \sim 0.20)\end{array}$ & low $($ WER $=1.60-1.65)$ \\
\hline $25 \mathrm{~mm}$ & $\begin{array}{l}\text { thinly pachyconic; subevolute } \\
\text { (ww/dm } \sim 0.62 ; \text { uw/dm } \sim 0.32 \text { ) }\end{array}$ & weakly depressed; strongly embracing (ww/wh 1.50; IZR 0.38) & moderate $($ WER 1.80) \\
\hline $55 \mathrm{~mm}$ & $\begin{array}{l}\text { thickly discoidal; subinvolute } \\
\text { (ww/dm } \sim 0.55 ; \mathrm{uw} / \mathrm{dm} \sim 0.16 \text { ) }\end{array}$ & $\begin{array}{l}\text { weakly compressed; strongly embracing (ww/wh } \sim 0.90 \text {; } \\
\text { IZR } \sim 0.36 \text { ) }\end{array}$ & high $($ WER 2.15) \\
\hline
\end{tabular}

Table 7. Conch dimensions (in $\mathrm{mm}$ ) and proportions for reference specimens of Calygirtyoceras confusionense sp. nov.

\begin{tabular}{|c|c|c|c|c|c|c|c|c|c|c|}
\hline & $\mathrm{dm}$ & ww & wh & uw & $\mathrm{ah}$ & ww/dm & ww/wh & uw/dm & WER & IZR \\
\hline HT MB.C.12001.1 & 58.8 & 25.8 & 29.5 & 8.1 & 18.9 & 0.44 & 0.87 & 0.14 & 2.17 & 0.36 \\
\hline PT MB.C.12000 & 37.3 & 19.9 & 17.7 & 8.3 & 10.1 & 0.53 & 1.12 & 0.22 & 1.88 & 0.43 \\
\hline PT UMNH IP 2692 & 31.1 & 17.5 & 14.1 & 7.7 & 8.1 & 0.56 & 1.24 & 0.25 & 1.83 & 0.43 \\
\hline PT UMNH IP 2693 & 30.3 & 16.5 & 14.8 & 6.4 & 8.8 & 0.54 & 1.11 & 0.21 & 1.99 & 0.40 \\
\hline PT MB.C.12001.2 & 29.9 & 18.3 & 13.6 & 7.5 & 8.2 & 0.61 & 1.34 & 0.25 & 1.90 & 0.40 \\
\hline PT UMNH IP 2690 & 18.0 & 11.5 & 7.5 & 6.3 & 4.4 & 0.64 & 1.54 & 0.35 & 1.77 & 0.40 \\
\hline PT UMNH IP 2689 & 13.3 & 10.2 & 5.3 & 6.6 & 3.0 & 0.77 & 1.92 & 0.50 & 1.65 & 0.44 \\
\hline
\end{tabular}

growth lines and faint umbilical ribs in juveniles; later stages with fine slightly biconvex growth lines. Shell constrictions in intermediate growth stages.

Description. - The biometric plots show that the species undergoes significant ontogenetic changes (Fig. 21E-G) in the conch width ratio, the umbilical width ratio, and the whorl expansion rate, which do not correlate with each other. Intraspecific variability appears to be rather low among the few specimens.

The cross section of paratype MB.C.12000 displays the conch ontogeny from the initial to the adult stage (Fig. 21C). Conch growth begins with a serpenticonic early juvenile stage, with the relative umbilical width rapidly increasing to a maximum of 0.65 at $6 \mathrm{~mm}$ conch diameter. The venter begins to flatten at $2 \mathrm{~mm}$ diameter, and the ventrolateral margin becomes angular. This 'calyx stage' (i.e. the stage with wide umbilicus, sharp umbilical edge, and flat venter) is visible up to $6 \mathrm{~mm}$ diameter, with a flat or slightly concave venter and a sharp ventrolateral edge. Subsequently, the venter becomes convexly rounded, and the former ventrolateral edge becomes an angular umbilical margin up to $15 \mathrm{~mm}$ diameter. Later stages show lateral compression of the conch. The largest specimens display tectiform whorl cross sections with keeled venters.

Holotype MB.C.12001.1 is the largest individual with $59 \mathrm{~mm}$ conch diameter (Fig. 20A). It represents the discus-shaped ontogenetic stage with an acute venter. The venter is already acute by half a whorl earlier (at $40 \mathrm{~mm}$ diameter), but the whorl cross section is tectiform. Another half whorl earlier, i.e. at the beginning of the last preserved whorl, the venter is slightly angular. The conch is widest at the slightly angular umbilical margin, and the umbilical wall is steep. The suture line of the holotype shows a Y-shaped external lobe with very narrow, lanceolate secondary prongs and a median saddle that reaches almost half of the external lobe depth. The ventrolateral saddle is strikingly asymmetric and rounded at its top; the adventive lobe is also asymmetric, $\mathrm{V}$-shaped with a convexly curved and steep ventral flank and an oblique, slightly sinuous dorsal flank (Fig. 21A).

Paratype MB.C.12001.2 represents the preadult stage at $30 \mathrm{~mm}$ conch diameter (Fig. 20B). It is thinly pachyconic $(\mathrm{ww} / \mathrm{dm}=0.61)$ with a narrow umbilicus $(\mathrm{uw} / \mathrm{dm}=$ 0.25). At its largest diameter, the venter changes from broadly rounded to tectiform and subangular. The conch is thickest at the pronounced umbilical margin that is slightly elevated to a low rim occupied by fine and sharp nodes. The growth lines run slightly biconvex across flanks and venter. Constrictions, which are deeper on the internal mould than on the shell surface (Fig. 21B), extend parallel to the growth lines on the inner flank area, but form a low ventral projection in contrast to the growth lines.

Smaller specimens such as paratype UMNH IP 2690 (18 $\mathrm{mm}$ diameter) are thinly pachyconic $(\mathrm{ww} / \mathrm{dm}=0.64)$ and show a broadly rounded venter as well as an angular 
Table 8. Conch ontogeny (Fig. 23) of Calygirtyoceras arcticum (Gordon, 1957).

\begin{tabular}{|c|c|c|c|}
\hline $\mathrm{dm}$ & conch shape & whorl cross section shape & aperture \\
\hline $1.5 \mathrm{~mm}$ & $\begin{array}{l}\text { thinly pachyconic; subevolute } \\
\text { (ww/dm } \sim 0.65 ; \text { uw/dm } \sim 0.40 \text { ) }\end{array}$ & $\begin{array}{l}\text { strongly depressed; moderately embracing }(\mathrm{ww} / \mathrm{wh} \sim 2.00 \\
\text { IZR } \sim 0.20)\end{array}$ & moderate $(\mathrm{WER} \sim 1.80)$ \\
\hline $5 \mathrm{~mm}$ & $\begin{array}{l}\text { thickly pachyconic; evolute } \\
(\mathrm{ww} / \mathrm{dm}=0.70-0.75 ; \mathrm{uw} / \mathrm{dm}=0.55-0.60)\end{array}$ & $\begin{array}{l}\text { extremely depressed; moderately embracing }(\mathrm{ww} / \mathrm{wh}=3.20-3.50 \\
\mathrm{IZR} \sim 0.15)\end{array}$ & low $($ WER $=1.55-1.60)$ \\
\hline $10 \mathrm{~mm}$ & $\begin{array}{l}\text { thickly pachyconic; evolute } \\
(\mathrm{ww} / \mathrm{dm}=0.75-0.80 ; \mathrm{uw} / \mathrm{dm}=0.45-0.50)\end{array}$ & $\begin{array}{l}\text { strongly depressed; moderately embracing }(\mathrm{ww} / \mathrm{wh}=2.10-2.50 \\
\mathrm{IZR} \sim 0.20)\end{array}$ & low $($ WER $=1.60-1.65)$ \\
\hline $25 \mathrm{~mm}$ & $\begin{array}{l}\text { thickly discoidal; subinvolute } \\
\text { (ww/dm } \sim 0.55 ; \mathrm{uw} / \mathrm{dm} \sim 0.25 \text { ) }\end{array}$ & $\begin{array}{l}\text { weakly depressed; strongly embracing (ww/wh } \sim 1.10 \text {; } \\
\text { IZR } \sim 0.40)\end{array}$ & moderate $($ WER $\sim 1.80)$ \\
\hline $55 \mathrm{~mm}$ & $\begin{array}{l}\text { thinly discoidal; involute } \\
\text { (ww/dm } \sim 0.45 ; \mathrm{uw} / \mathrm{dm} \sim 0.12 \text { ) }\end{array}$ & $\begin{array}{l}\text { weakly compressed; strongly embracing (ww/wh } \sim 0.75 \text {; } \\
\text { IZR 0.40) }\end{array}$ & high (WER 2.25) \\
\hline
\end{tabular}

umbilical margin (Fig. 20D). The growth lines are lamellose in this stage and extend with a wide projection across the venter, parallel to the irregularly spaced constrictions.

By the end of its 'calyx stage' (13 $\mathrm{mm}$ diameter) paratype UMNH IP 2689 is thickly pachyconic (ww/dm = 0.77 ) with a wide umbilicus ( $\mathrm{uw} / \mathrm{dm}=0.40$ ). Weak ribs ornament the sharp umbilical edge. Growth lines and shell constrictions run with a wide arch across the broad venter (Fig. 20E).

Discussion. - Calygirtyoceras confusionense is the girtyoceratid with the widest conch among the material from the Chainman Formation. Co-occurring specimens of $C$. arcticum have, at comparable conch diameters, a ww/wh ratio 0.10 lower than that of $C$. confusionense. C. arcticum (Gordon, 1957) from the Kiruktagiak River in Alaska differs from $C$. confusionense by having a less angular umbilical margin, a rounded venter in the juvenile stage (applanate or even slightly concave in $C$. confusionense), and fine spiral lines. $C$. confusionense also exhibits much coarser growth lines.

The Moroccan species C. darkaouaense Korn, Klug \& Mapes, 1999 possesses a wide conch like $C$. confusionense, but lacks the tectiform preadult whorl cross section and coarse growth lines. Calygirtyoceras zrigatense Korn \& Ebbighausen, 2006, also known from Morocco, as well as the European species C. platyforme (Moore, 1946) and C. moorei (Nicolaus, 1963) have more slender conchs.

\section{Calygirtyoceras arcticum (Gordon, 1957)}

Figures 22, 23

*1957 Girtyoceras arcticum Gordon, p. 50, pl. 6, figs 20-22.

Holotype. - Specimen USNM 118976, illustrated by Gordon (1957, pl. 6, figs 20-22).

Type locality and horizon. - USGS locality 14149, Kiruk- tagiak River (Brooks Range); Kuna Formation, most probably Calygirtyoceras arcticum Biozone.

Material. - 111 specimens; conch diameter up to $66 \mathrm{~mm}$.

Diagnosis. - Species of Calygirtyoceras with a thickly pachyconic, widely umbilicate conch at 6-8 $\mathrm{mm}$ diameter ( ww/dm $=0.70-0.80 ; \mathrm{uw} / \mathrm{dm}=0.55-0.60)$, a thickly discoidal, moderately umbilicate conch at $20 \mathrm{~mm}$ diameter (ww/dm $=0.50-0.60$; uw/dm $=0.25-0.35$ ), and a discoidal, narrowly umbilicate conch at 50-60 $\mathrm{mm}$ diameter ( $\mathrm{ww} / \mathrm{dm}=0.40 ; \mathrm{uw} / \mathrm{dm}=0.10)$. Whorl cross section shows conspicuous ontogenetic changes; crescent-shaped in early juveniles, later subtrapezoidal with pronounced ventrolateral margin and flat venter (2-6 mm diameter), followed by an intermediate stage with rounded venter and angular umbilical margin (10-20 mm diameter), a preadult stage with laterally compressed whorls and a subacute venter (30-40 mm diameter), and an adult oxyconic stage (50 mm diameter). Ornament is fine prorsiradiate growth lines in juveniles; later stages with fine and slightly biconvex growth lines, occasionally with fine spiral lines. Weak shell constrictions in intermediate growth stages.

Description. - The ontogeny plots demonstrate the conspicuous developmental changes of the species (Fig. 23). Three distinctive ontogenetic stages can be separated regarding the proportions of the conch dimensions. It is noteworthy, however, that the three biometric conch parameters whorl width index (ww/dm), umbilical width index (uw/dm) and whorl expansion rate (WER) do not show a parallel development, so that the separation of growth stages cannot be sharp. In an early juvenile stage (up to 2-3 mm diameter), widening of the umbilicus up to $\mathrm{uw} / \mathrm{dm}=0.60$ is paralleled by a reduction of conch width to $\mathrm{ww} / \mathrm{dm}=0.60$ and a reduction of the whorl expansion rate to 1.50 . Up to $8 \mathrm{~mm}$ diameter, the conch becomes thicker and reaches a maximum ww/dm ratio of 0.85 . In this growth interval the umbilicus maintains its width and the aperture becomes slightly higher (WER $=1.65)$. The following growth interval is characterized by a continuous 

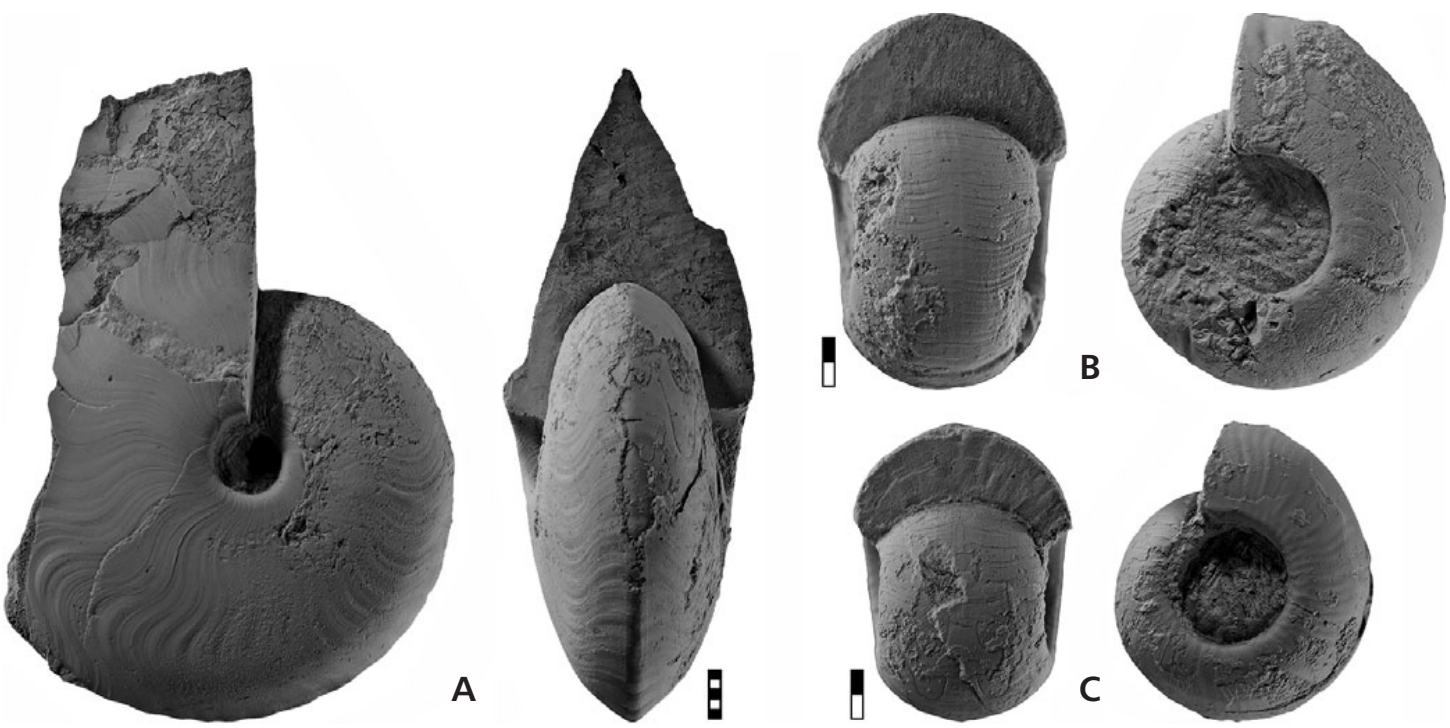

Figure 22. Calygirtyoceras arcticum (Gordon, 1957). • A - specimen UMNH IP 2725 from bed 7 (sample 93UTMI-25) of Jensen Wash; $\times 1.0$. - B - specimen UMNH IP 2738 from bed 7 (sample 93UTMI-25) of Jensen Wash; $\times 2.5$ • C - specimen UMNH IP 2727 from bed 7 (sample 93UTMI-25) of Jensen Wash; $\times 2.5$.

Table 9. Conch dimensions (in $\mathrm{mm}$ ) and proportions for reference specimens of Calygirtyoceras arcticum (Gordon, 1957).

\begin{tabular}{lcccccccccc}
\hline & $\mathrm{dm}$ & ww & \multicolumn{1}{c}{ wh } & uw & \multicolumn{1}{c}{ ah } & ww/dm & ww/wh & uw/dm & WER & IZR \\
\hline UMNH IP 2725 & 66.0 & 25.5 & 36.4 & 6.9 & 22.6 & 0.39 & 0.70 & 0.10 & 2.31 & 0.38 \\
UMNH IP 2718 & 31.9 & 13.0 & 15.1 & 7.3 & 8.9 & 0.41 & 0.86 & 0.23 & 1.93 & 0.41 \\
UMNH IP 2724 & 21.2 & 12.6 & 9.8 & 5.4 & 5.8 & 0.60 & 1.29 & 0.25 & 1.89 & 0.41 \\
UMNH IP 2726 & 15.7 & 10.8 & 6.4 & 5.6 & 3.9 & 0.69 & 1.69 & 0.35 & 1.76 & 0.39 \\
UMNH IP 2738 & 15.2 & 10.0 & 6.2 & 5.7 & 3.8 & 0.66 & 1.61 & 0.38 & 1.77 & 0.39 \\
UMNH IP 2727 & 12.2 & 8.8 & 5.1 & 4.8 & 2.6 & 0.73 & 1.73 & 0.39 & 1.60 & 0.50 \\
\hline
\end{tabular}

decrease in the ww/dm ratio and a simultaneous reduction in the relative umbilical width as well as heightening of the whorl expansion rate.

Two sectioned specimens, UMNH IP 2718 from Granite Mountain and UMNH IP 2724 from Jensen Wash, illustrate the ontogenetic changes of the conch from the initial stage up to a diameter of $32 \mathrm{~mm}$ (Fig. 23A, B). The innermost whorls up to $2 \mathrm{~mm}$ conch diameter are crescentshaped, thereafter the venter flattens and development of a ventrolateral edge takes place. This 'calyx stage' is present up to $5.5 \mathrm{~mm}$ diameter, followed by a stage in which the ventrolateral edge is transformed into a subangular umbilical margin, paralleled by slight lateral compression of the whorls that results in a higher aperture. This stage ends at about $20 \mathrm{~mm}$ diameter, when the venter becomes narrower. By $30 \mathrm{~mm}$ diameter the venter is subacute.

The largest available specimen is UMNH IP 2725 from Jensen Wash; it has a conch diameter of $66 \mathrm{~mm}$ (Fig. 23A). The end of the body chamber of the specimen is laterally crushed, but it can be assumed that it had an oxyconic outline. A subacute venter with inconspicuous ventral nodes and a rounded umbilical margin can be seen in the well-preserved part of the body chamber, when the conch has a diameter of $44 \mathrm{~mm}$. The shell has fine, strongly biconvex growth lines in this stage.

The sectioned specimen UMNH IP 2718 (32 mm diameter) represents the preadult stage; its venter is subacute and its umbilical margin subangular. The shell is ornamented with fine biconvex growth lines that show a deep ventral sinus. Faint shell constrictions occur on the flanks, particularly in the ventrolateral area (Fig. 23A, D).

Smaller specimens such as UMNH IP 2727 (12 mm diameter) are just past the 'calyx stage' (Fig. 23B) and show broadly rounded venters and subangular umbilical margins. Lamellar growth lines with slightly prorsiradiate course and faint spiral lines decorate the shell, and the internal mould shows impressions of these growth lines. Irregularly spaced steinkern constrictions run parallel to the growth lines.

Suture lines have been obtained from three different growth stages (Fig. 23E-G). They show the characteristic outline of a girtyoceratid species with an ontogenetic widening of the external lobe and a heightening of the median saddle. 

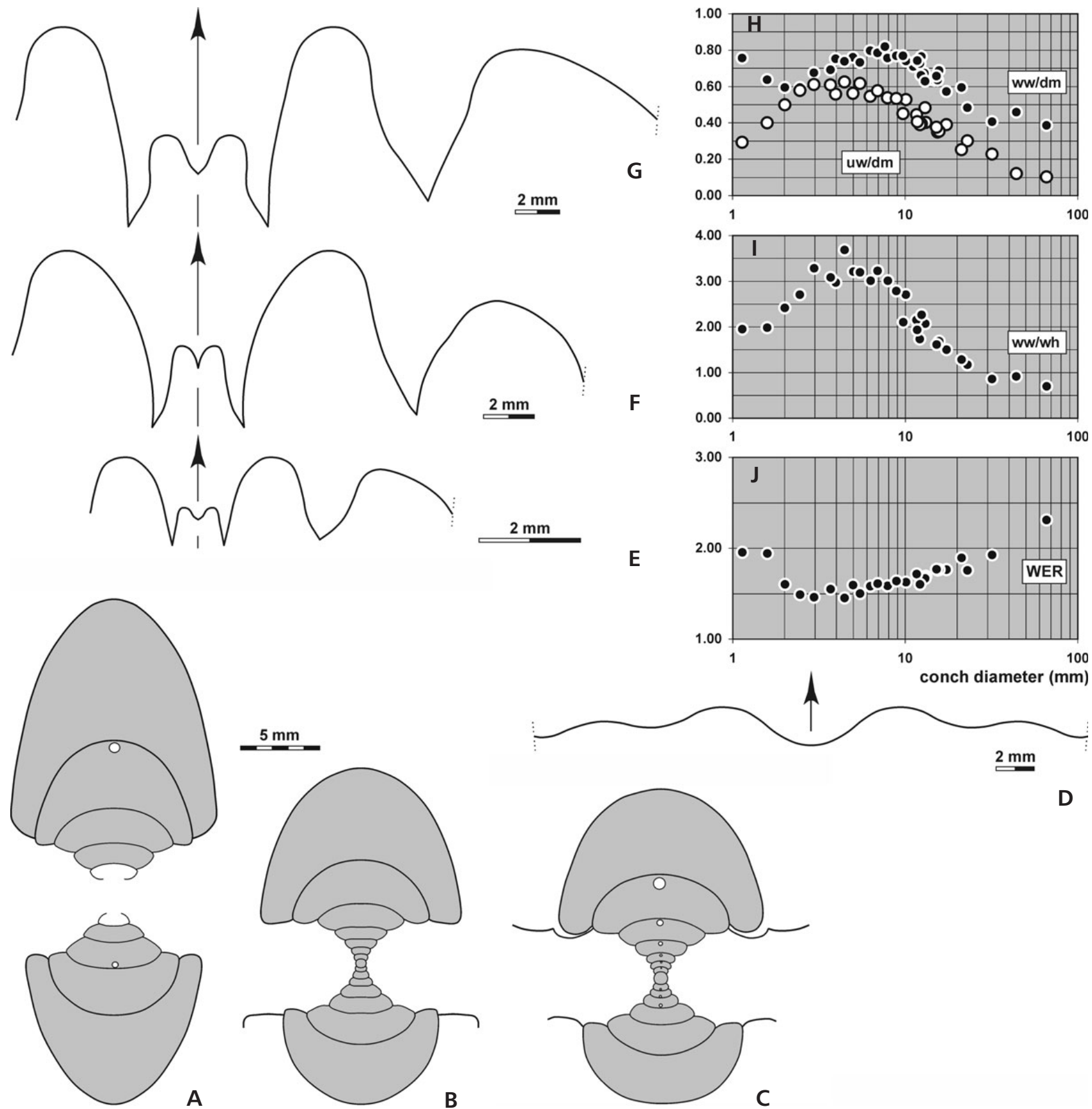

D

Figure 23. Calygirtyoceras arcticum (Gordon, 1957). • A - cross section of specimen UMNH IP 2718 from bed 25 (sample 05UTJU-12) of Granite Mountain-South; $\times 2.5$. $\bullet$ B - cross section of specimen UMNH IP 2724 from bed 7 (sample 93UTMI-25) of Jensen Wash; $\times 2.5$. $\bullet$ C cross section (redrawn from Gordon, 1957) of paratype USNM 118977 from the Kiruktagiak River; $\times 2.5$. $\bullet$ D - growth line course of specimen UMNH IP 2718 from bed 25 (sample 05UTJU-12) of Granite Mountain-South, at $12.0 \mathrm{~mm}$ ww, $12.5 \mathrm{~mm}$ wh; $\times 3.0$. $\bullet$ E -suture line of specimen UMNH IP 2727 from bed 7 (sample 93UTMI-25) of Jensen Wash, at $7.2 \mathrm{~mm}$ ww, $3.2 \mathrm{~mm}$ wh; $\times 8.0 . \bullet \mathrm{F}$ - suture line of specimen UMNH IP 2718 from bed 25 (sample 05UTJU-12) of Granite Mountain-South, at $31.0 \mathrm{~mm}$ diameter, $13.0 \mathrm{~mm}$ ww, $14.5 \mathrm{~mm}$ wh; $\times 4.0$. $\bullet \mathrm{G}$ - suture line of specimen UMNH IP 2725 from bed 7 (sample 93UTMI-25) of Jensen Wash, at $18.3 \mathrm{~mm}$ ww, $17.5 \mathrm{~mm}$ wh; $\times 3.5 . \bullet \mathrm{H}-\mathrm{J}-$ ontogenetic development of the conch width index (ww/dm), umbilical width index (uw/dm), whorl width index (ww/wh), and whorl expansion rate (WER) of all available specimens.

Discussion. - Calygirtyoceras confusionense is similar, but has a wider conch and umbilicus at comparable diameters. The calyx stage is also less well developed in C. arcticum, with a less angular ventrolateral edge and less strongly flat- tened venter (Fig. 23C). C. arcticum has a wider conch than C. platyforme (Moore, 1946), C. moorei (Nicolaus, 1963), and C. zrigatense Korn \& Ebbighausen, 2006, but is more slender than C. darkaouaense Korn, Klug \& Mapes, 1999. 


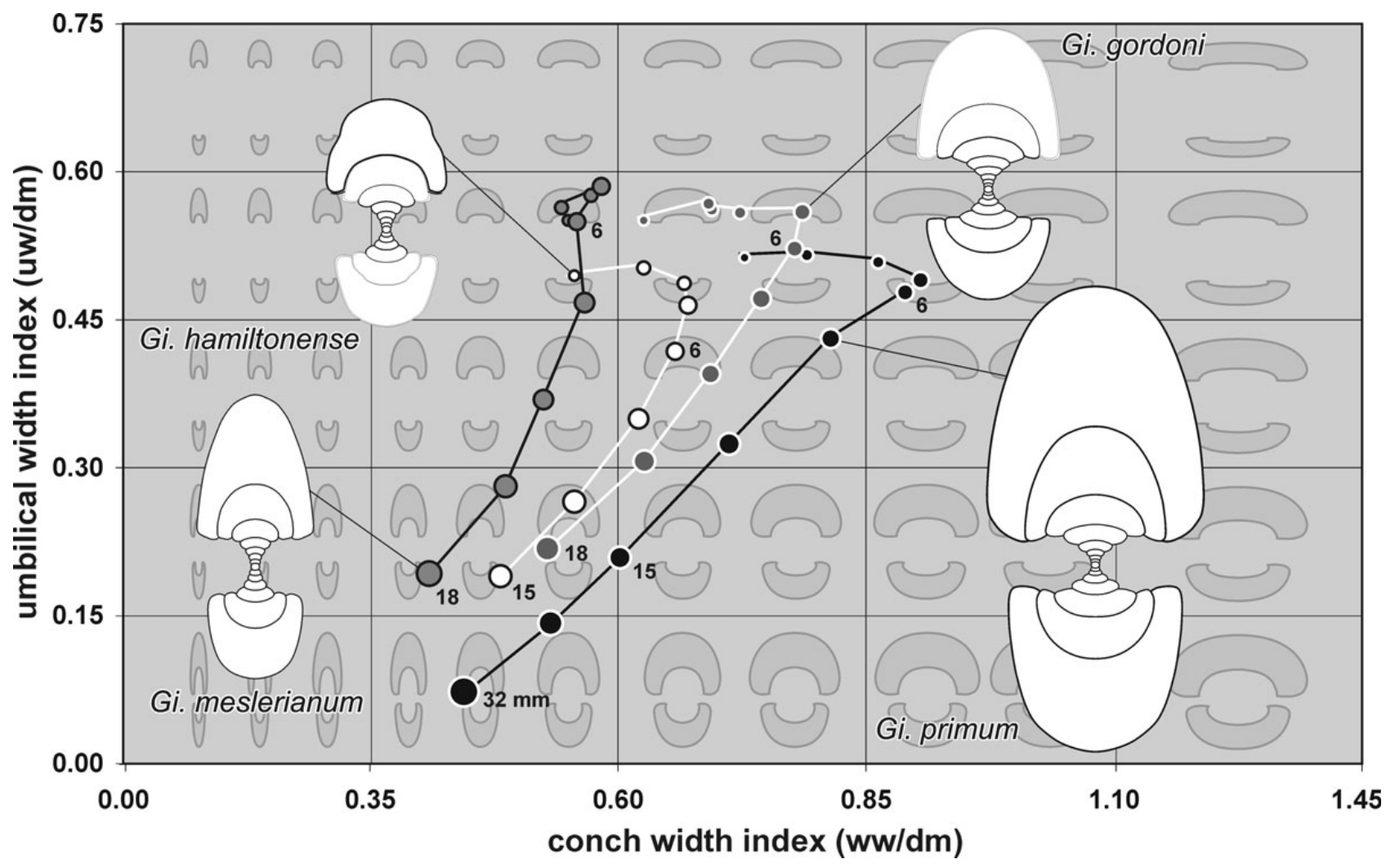

Figure 24. Ontogenetic trajectories (ww/dm and uw/dm relations) of Girtyoceras from the Chainman Formation of the Antler Foreland Basin and the Caney Shale of Oklahoma; illustrated are growth stages larger than $2 \mathrm{~mm}$ diameter. Numbers refer to the conch diameters at which the ratios were taken. Girtyoceras primum sp. nov., paratype UMNH IP 2834; Girtyoceras gordoni sp. nov., paratype UMNH IP 3103; Girtyoceras hamiltonense sp. nov., paratype MB.C.12005.1; Girtyoceras meslerianum (Girty, 1909), specimen MB.C.12040 from Jack Fork Creek near Ada.

\section{Genus Girtyoceras Wedekind, 1918}

Type species. - Adelphoceras meslerianum Girty, 1909 (original designation).

Genus definition. - Girtyoceratidae with moderately large conch (up to $150 \mathrm{~mm}$ diameter) that passes through very different morphological stages during ontogeny: in early juveniles widely umbilicate (uw/dm $=0.45-0.55$ ) with crescent-shaped whorl cross section, later thickly discoidal or pachyconic with subangular or rounded umbilical margin, intermediate stage with rounded flanks and venter, and adult stage lenticular-oxyconic. Without or with very faint ventrolateral grooves. Suture line with V-shaped external lobe, moderately high median saddle, narrowly rounded ventrolateral saddle, and V-shaped adventive lobe.

Included species. - aeulkei: Girtyoceras aeulkei Korn, 1988, p. 57; Rhenish Mountains; boreale: Girtyoceras boreale Kusina, 1987, p. 58; Novaya Zemlya; brainerdi: Dryochoceras Brainerdi Morgan, 1924, p. 185; Oklahoma [synonym of G. meslerianum]; brueningianum: Homoceras brüningianum Schmidt, 1925, p. 580; Rhenish Mountains; complicatum: Ammonites complicatus de Koninck 1844, p. 567; Belgium; cowdalense: Girtyoceras cowdalense Moore, 1946, p. 406; Yorkshire; deani: Girtyoceras deani Moore, 1946, p. 399; Yorkshire; discus: Goniatites discus Roemer 1855, p. 95; Harz [homonym of Goniatites discus Roemer 1850; synonym of G. ibergense]; duekemoerense: Girtyoceras duekemoerense Korn, 1988, p. 54; Rhenish Mountains; edwinae: Girtyoceras edwinae Korn, 1988, p. 61; Rhenish Mountains; endicottense: Girtyoceras endicottense Gordon, 1957, p. 51; Alaska; excavatum: Goniatites excavatus Phillips, 1836, p. 235; Yorkshire; finale: Girtyoceras modestum finale Ruzhencev \& Bogoslovskaya, 1971, p. 175; South Urals; glabrum: Girtyoceras glabrum Ruzhencev \& Bogoslovskaya, 1971, p. 171; South Urals; goii: Girtyoceras goii Korn, 1988, p. 58; Rhenish Mountains; gordoni: Girtyoceras gordoni sp. nov.; Antler Foreland Basin; hamiltonense: Girtyoceras hamiltonense sp. nov.; Antler Foreland Basin; heishantouense: Jeminayceras heishantouense Wang, 1983, p. 520; Xinjiang; ibnkhaldouni: Girtyoceras ibnkhaldouni Korn \& Ebbighausen, 2008, p. 92; Moroccan Meseta; ibergense: Girtyoceras ibergense Korn, 1992, p. 278; Harz; kazakhorum: Girtyoceras kazakhorum Ruzhencev, 1966, p. 55; South Urals; latum: Girtyoceras latum Ruzhencev \& Bogoslovskaya, 1971, p. 170; South Urals; luscinia: Girtyoceras luscinia 

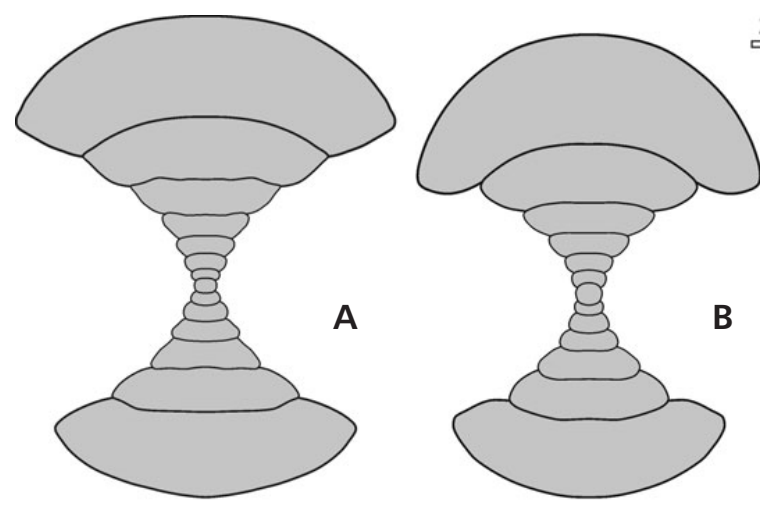

$2 \mathrm{~mm}$
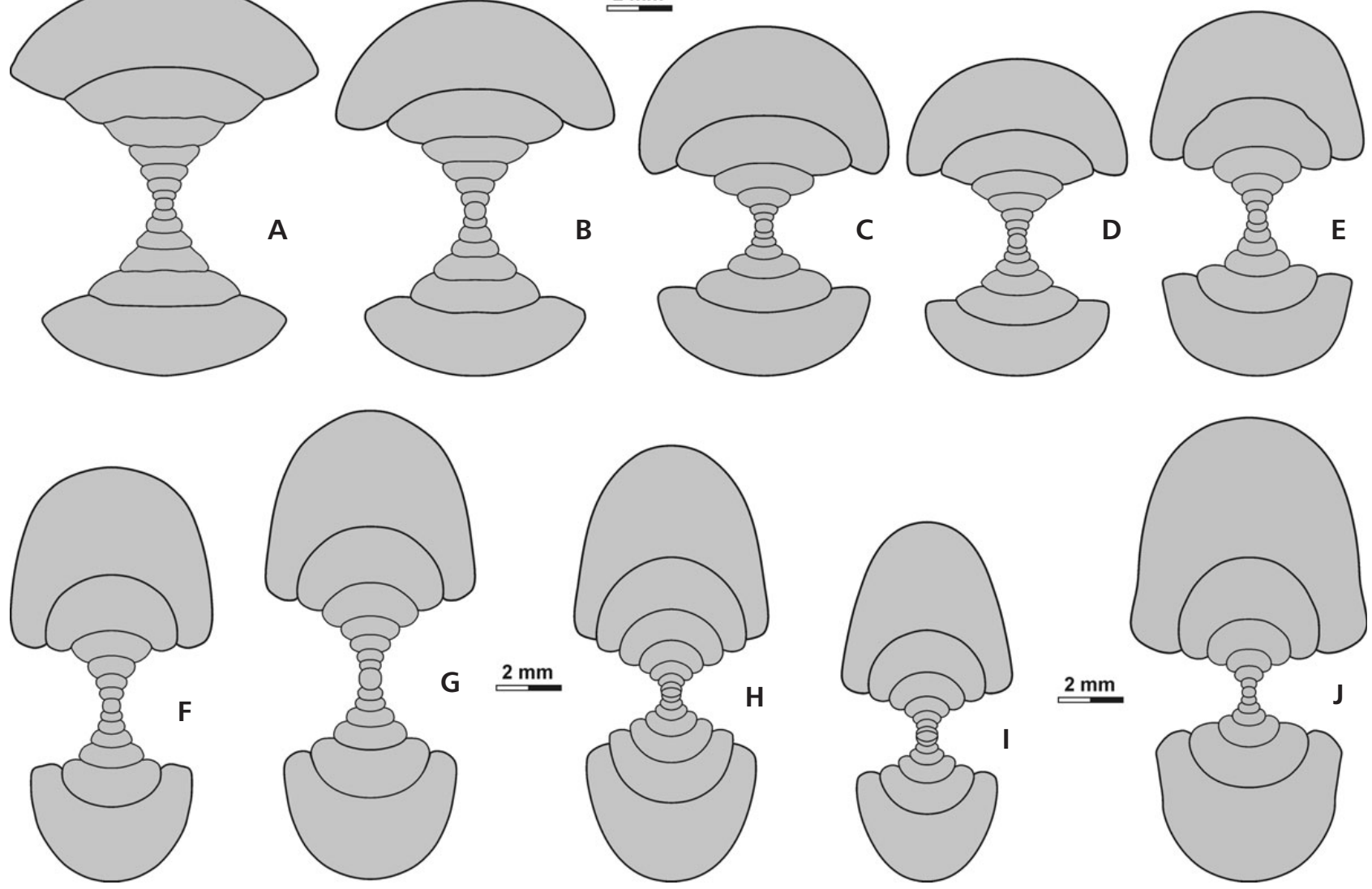

Figure 25. Cross sections of the inner whorls of various species of Girtyoceras for comparison; all $\times 4 . \cdot \mathrm{A}-$ Calygirtyoceras confusionense sp. nov., paratype MB.C.12000 from bed 6 of Middle Confusion Range 1. B - Calygirtyoceras arcticum (Gordon, 1957), specimen UMNH IP 2718 from bed 25 (sample 05UTJU-12) of Granite Mountain-South. • C - Girtyoceras primum sp. nov., paratype UMNH IP 2834 from bed 16 (sample 00UTMI-1n) of Needle Range. • D - Girtyoceras gordoni sp. nov., paratype UMNH IP 3103 from bed 19 (sample 97UTMI-13) of Jensen Wash. • E - Girtyoceras hamiltonense sp. nov., paratype UMNH IP 3128 from bed 44 (sample 07NVWP-3) of Hamilton Canyon. • F - Girtyoceras meslerianum (Girty, 1909), specimen MB.C.12040 from the Delaware Creek Member of the Caney Shale of Jackfork Creek (Oklahoma). • G - Girtyoceras meslerianum (Girty, 1909), specimen USNM 119628 (redrawn from Gordon, 1965) from the Delaware Creek Member of the Caney Shale of USGS locality 2083 (Oklahoma). • H - Girtyoceras luscinia Korn, 1988, specimen MB.C.13213.4 from the Glib en-Nâam Formation of the Chebket el Hamra (Morocco). • I - Girtyoceras ibnkhaldouni Korn \& Ebbighausen, 2008, paratype MB.C.13214.4 from the Glib en-Nâam Formation of the Chebket el Hamra (Morocco). - J - Girtyoceras goii Korn, 1988, paratype WMN 10044 (redrawn from Korn, 1988) from the Herdringen Formation of Estinghausen (Rhenish Mountains).

Korn, 1988, p. 52; Rhenish Mountains; margaritatum: Girtyoceras margaritatum Korn, 1988, p. 55; Rhenish Mountains; medium: Girtyoceras modestum medium Ruzhencev \& Bogoslovskaya, 1971, p. 174; South Urals; meslerianum: Adelphoceras meslerianum Girty, 1909, p. 66; Oklahoma; modestum: Girtyoceras modestum modestum Ruzhencev \& Bogoslovskaya, 1971, p. 174; South Urals; premeslerianum: Girtyoceras premeslerianum Moore, 1946, p. 401; Yorkshire; primum: Girtyoceras primum sp. nov.; Antler Foreland Basin; shorrocksi: Girtyoceras shorrocksi Moore, 1946, p. 413; Lancashire; simplex: Girtyoceras simplex Moore, 1946, p. 400; Yorkshire; tomasi: Girtyoceras tomasi Wagner-Gentis, 1987, p. 31; South Portugal; waitei: Girtyoceras waitei Moore, 1946, p. 415; Yorkshire; welleri: Girtyoceras welleri Gordon, 1965, p. 233; Arkansas; ?acutum: Sagittoceras acutum Hind, 1918, p. 447; Yorkshire.
Discussion. - Girtyoceras is nearly global in distribution. About 30 more or less well-described species are in the literature. Korn \& Ebbighausen (2008) gave an overview on the European species, of which 14 were grouped and briefly characterized. These authors separated one group with thinly discoidal conch $(\mathrm{ww} / \mathrm{dm}=$ less than 0.50$)$ from a second group with thickly discoidal or pachyconic conch (ww/dm $=$ more than 0.50), measured in specimens of $15 \mathrm{~mm}$ conch diameter. The American species can be grouped as follows:

Group A (more slender forms):

G. meslerianum (Girty, 1909): slender form (ww/dm = $0.42-0.48$, uw/dm $=0.22-0.25$ at $15 \mathrm{~mm}$ diameter) with strong biconvex constrictions and fine riblets in the juvenile stage; sharpening of the venter at about $20 \mathrm{~mm}$ diameter; 
Table 10. Conch ontogeny (Fig. 27) of Girtyoceras primum sp. nov.

\begin{tabular}{|c|c|c|c|}
\hline $\mathrm{dm}$ & conch shape & whorl cross section shape & aperture \\
\hline $1.5 \mathrm{~mm}$ & $\begin{array}{l}\text { thinly pachyconic; evolute } \\
(\mathrm{ww} / \mathrm{dm}=0.60-0.70 ; \mathrm{uw} / \mathrm{dm}=0.40-0.55)\end{array}$ & $\begin{array}{l}\text { strongly depressed; moderately embracing }(\mathrm{ww} / \mathrm{wh}=2.15-2.45 \\
\mathrm{IZR}=0.20-0.25)\end{array}$ & low $($ WER 1.65) \\
\hline $5 \mathrm{~mm}$ & $\begin{array}{l}\text { thickly pachyconic; evolute } \\
(\mathrm{ww} / \mathrm{dm}=0.75-0.85 ; \mathrm{uw} / \mathrm{dm}=0.50-0.55)\end{array}$ & $\begin{array}{l}\text { extremely depressed; moderately embracing }(\mathrm{ww} / \mathrm{wh}=2.70-3.20 \\
\mathrm{IZR}=0.20-0.25)\end{array}$ & low $($ WER 1.65) \\
\hline $10 \mathrm{~mm}$ & $\begin{array}{l}\text { pachyconic; evolute } \\
(\mathrm{ww} / \mathrm{dm}=0.70-0.75 ; \mathrm{uw} / \mathrm{dm}=0.40-0.45)\end{array}$ & $\begin{array}{l}\text { moderately depressed; moderately embracing }(\mathrm{ww} / \mathrm{wh}=1.70-2.00 \\
\mathrm{IZR}=0.25-0.30)\end{array}$ & mo \\
\hline $25 \mathrm{~mm}$ & $\begin{array}{l}\text { thinly discoidal; subinvolute } \\
(\mathrm{ww} / \mathrm{dm}=0.40-0.45 ; \mathrm{uw} / \mathrm{dm}=0.15-0.25)\end{array}$ & $\begin{array}{l}\text { weakly compressed; strongly embracing }(\mathrm{ww} / \mathrm{wh}=0.80-1.00 \\
\mathrm{IZR}=0.35-0.45)\end{array}$ & high $($ WER $=2.00-2.25)$ \\
\hline $42 \mathrm{~mm}$ & $\begin{array}{l}\text { extremely discoidal; involute } \\
\text { (ww/dm } \sim 0.34 ; \mathrm{uw} / \mathrm{dm} \sim 0.12 \text { ) }\end{array}$ & $\begin{array}{l}\text { weakly compressed; strongly embracing (ww/wh } \sim 0.62 \text {; } \\
\text { IZR 0.40) }\end{array}$ & very high (WER 2.26) \\
\hline
\end{tabular}

G. welleri Gordon, 1965: slender form $(\mathrm{ww} / \mathrm{dm}=0.45$, $\mathrm{uw} / \mathrm{dm}=0.23$ at $14 \mathrm{~mm}$ diameter) with weak biconvex constrictions; sharpening of the venter at about $13 \mathrm{~mm}$ diameter;

G. endicottense Gordon, 1957: slender form (ww/dm = 0.44 , uw $/ \mathrm{dm}=0.26$ at $14 \mathrm{~mm}$ diameter) with almost straight constrictions; venter with a fine longitudinal groove, no sharpening of the venter at least until $26 \mathrm{~mm}$ diameter.

Group B (stouter forms):

G. primum sp. nov.: stout form (ww/dm $=0.55-0.62$, $\mathrm{uw} / \mathrm{dm}=0.20-0.28$ at $15 \mathrm{~mm}$ diameter) with weak biconvex constrictions, constrictions form a ventral projection in the juvenile stage; sharpening of the venter at about $45 \mathrm{~mm}$ diameter;

G. gordoni sp. nov.: moderately stout form $(\mathrm{ww} / \mathrm{dm}=$ $0.50-0.55, \mathrm{uw} / \mathrm{dm}=0.20-0.24$ at $15 \mathrm{~mm}$ diameter) with strong concavo-convex constrictions with high ventrolateral projection; sharpening of the venter not before $20 \mathrm{~mm}$ diameter:

G. hamiltonense sp. nov.: slender to moderately stout form $(\mathrm{ww} / \mathrm{dm}=0.48-0.53, \mathrm{uw} / \mathrm{dm}=0.15-0.25$ at $15 \mathrm{~mm}$ diameter) with strong biconvex constrictions with moderately high ventrolateral projection; sharpening of the venter at about $40 \mathrm{~mm}$ diameter.

The three Chainman Formation species are all stouter forms, in contrast to the Alaskan and American Midcontinent forms. Within the succession in the Chainman Formation, a trend from stouter towards more slender forms can be observed (Fig. 24).

Another trend within the genus is the regression of the angular umbilical margin in the juvenile stage towards a rounded umbilical margin. This trend has already begun in the genus Calygirtyoceras, but the angular umbilical margin is still present in stratigraphically older species of Girtyoceras, such as G. primum (Fig. 25). The youngest species from the Camp Canyon Member is G. hamiltonense, which has an almost rounded umbilical margin, similar to G. meslerianum from the Caney Shale and to the European/African species G. luscinia, G. ibnkhaldouni, and $G$. goii, of which the inner whorls are well-known.
Species of Girtyoceras are usually separated on the basis of conch shape, ontogeny, and ornament, not sutural characters. This is mainly because the suture line is often dependent on the conch form. Species of Girtyoceras can be significantly different in their conch shape at comparable diameters, and thus suture lines are very difficult to compare.

Girtyoceras primum sp. nov.

Figures 26, 27

1984 Girtyoceras n. sp. A; Webster et al., p. 31.

Derivation of name. - After Lat. primum = the first, an allusion to its basal phylogenetic position in Girtyoceras.

Holotype. - Specimen UMNH IP 2865, illustrated in Fig. 26C.

Type locality and horizon. - South Burbank Hills, bed 6 (sample 01UTMI-3); Camp Canyon Member of Chainman Formation, Girtyoceras primum Biozone.

Material. - The holotype and 320 paratypes; conch diameter up to $77 \mathrm{~mm}$.

Diagnosis. - Species of Girtyoceras with a thickly pachyconic, widely umbilicate conch at $6-8 \mathrm{~mm}$ diameter $(\mathrm{ww} / \mathrm{dm}=$ $0.80-0.90$; uw/dm $=0.45-0.55$ ), a thickly discoidal, narrowly umbilicate conch at $20 \mathrm{~mm}$ diameter $(\mathrm{ww} / \mathrm{dm}=$ $0.45-0.55 ; \mathrm{uw} / \mathrm{dm}=0.25-0.35$ ), and a discoidal, narrowly umbilicate conch at $40 \mathrm{~mm}$ diameter $(\mathrm{ww} / \mathrm{dm}=0.35-0.40$; $\mathrm{uw} / \mathrm{dm}=0.10-0.15)$. Whorl cross section extremely depressed in the juveniles (2-8 mm diameter), followed by an intermediate stage with rounded venter and subangular umbilical margin (10-20 mm diameter), a preadult stage with laterally compressed whorls and rounded venter $(30-40 \mathrm{~mm}$ diameter), and an adult oxyconic stage (50 mm diameter). Ornament of fine prorsiradiate growth lines in juveniles; later stages show fine biconvex growth lines. Very weak shell constrictions in intermediate growth stages. 

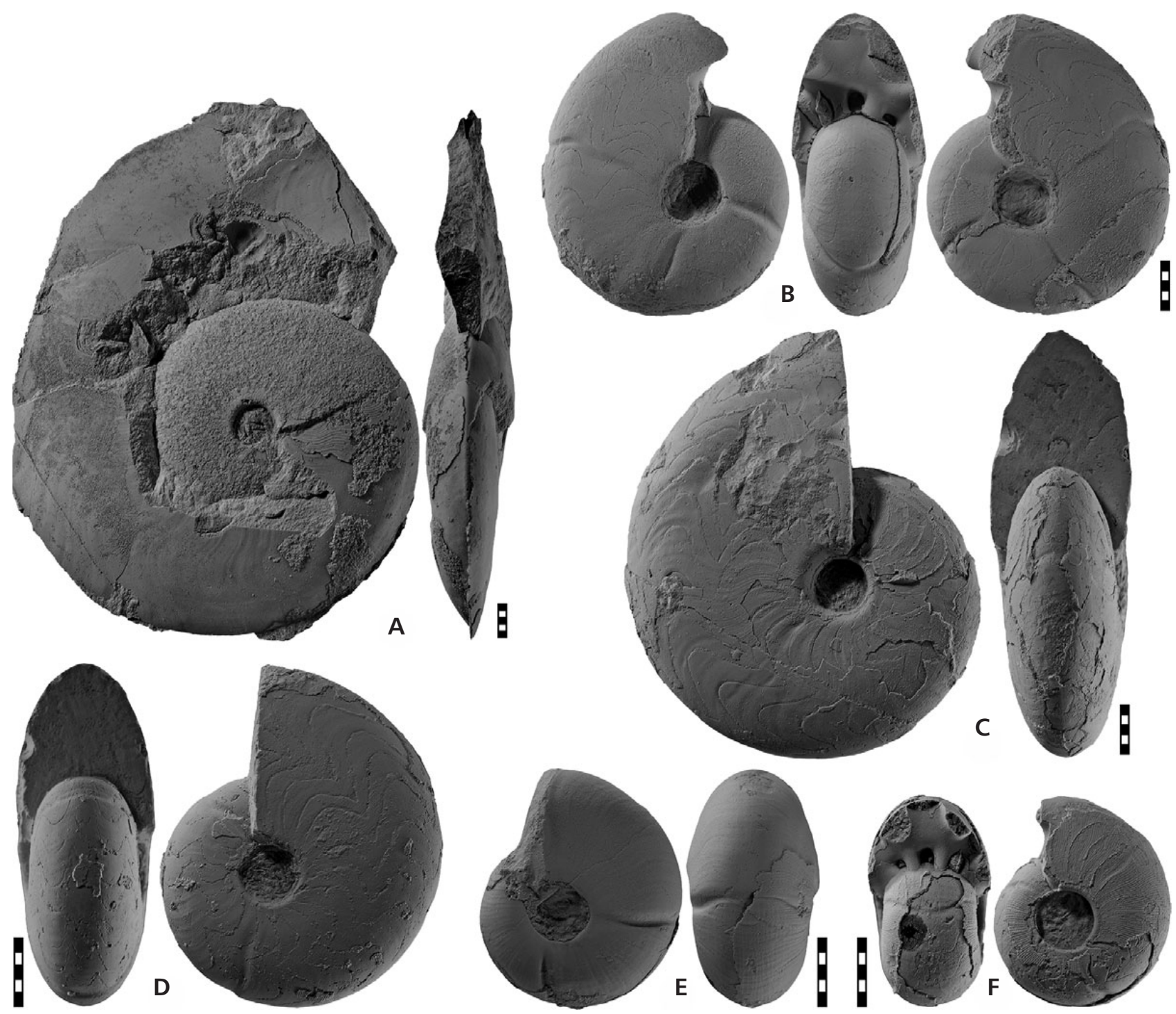

Figure 26. Girtyoceras primum sp. nov. • A - paratype UMNH IP 2835 from bed 16 (sample 00UTMI-1n) of Needle Range; $\times 1.0$. $\bullet$ B - paratype UMNH IP 2952 from bed 25 (sample 05UTJU-12) of Granite Mountain South; $\times 1.5$. $・$ C - holotype UMNH IP 2865 from bed 6 (sample 01UTMI-3) of South Burbank Hills; $\times 1.5 . \bullet$ D - paratype UMNH IP 2864 from bed 6 (sample 01UTMI-3) of South Burbank Hills; $\times 2.0 . \bullet$ E - paratype UMNH IP 3084 from bed 25 (sample 94UTJU-9) of Granite Mountain South; × 2.0. • F - paratype UMNH IP 2953 from bed 25 (sample 05UTJU-12) of Granite Mountain South; $\times 2.0$.

Description. - Four paratypes were sectioned to study the conch ontogeny (of which three are illustrated in Fig. 27A-C), and a number of specimens were measured. Therefore, the ontogeny plots allow an insight in the intraspecific variability of the species (Fig. 27K-M). Juveniles up to $7 \mathrm{~mm}$ conch diameter show an especially wide range of conch thickness, whereas growth stages above $8 \mathrm{~mm}$ diameter are almost uniform. Variability in the uw/dm index as well as the whorl expansion rate is limited. The plots show the characteristic ontogenetic patterns of a girtyoceratid species; (1) a serpenticonic stage up to $3 \mathrm{~mm}$ diameter, (2) a cadyconic stage between 3 and $10 \mathrm{~mm}$ diameter, and a laterally compressed preadult and adult stage with extreme narrowing of the umbilicus.
Paratype UMNH IP 2834 is a cross section that displays the ontogeny up to $32 \mathrm{~mm}$ conch diameter (Fig. 27A). Its conch ontogeny begins with crescent-shaped early whorls, and up to $6 \mathrm{~mm}$ diameter, the whorl cross section is strongly depressed ventrally with a wide and broadly rounded venter. At $8 \mathrm{~mm}$ diameter, the whorl becomes higher, resulting in an increase of the whorl expansion rate $($ WER $=1.75)$. This trend is retained in the following whorls, where the WER is continuously raised to a value of 2.22 at $32 \mathrm{~mm}$ diameter. The conch is lenticular in this stage, with a ww/dm ratio of 0.44 , compressed whorl, and a narrowly rounded venter.

Paratype UMNH IP 2835 is, with a maximum diameter of $77 \mathrm{~mm}$, the largest available specimen (Fig. 26A). Its 

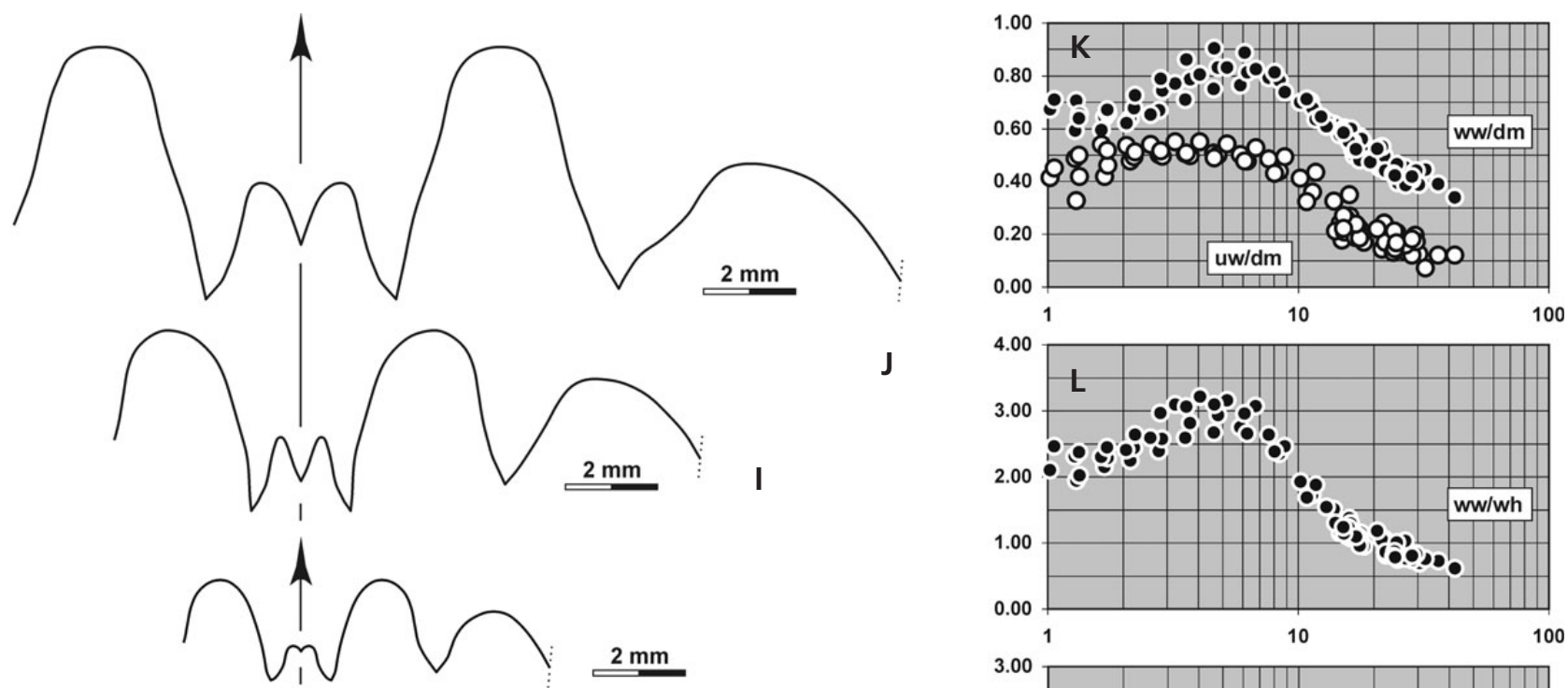

H
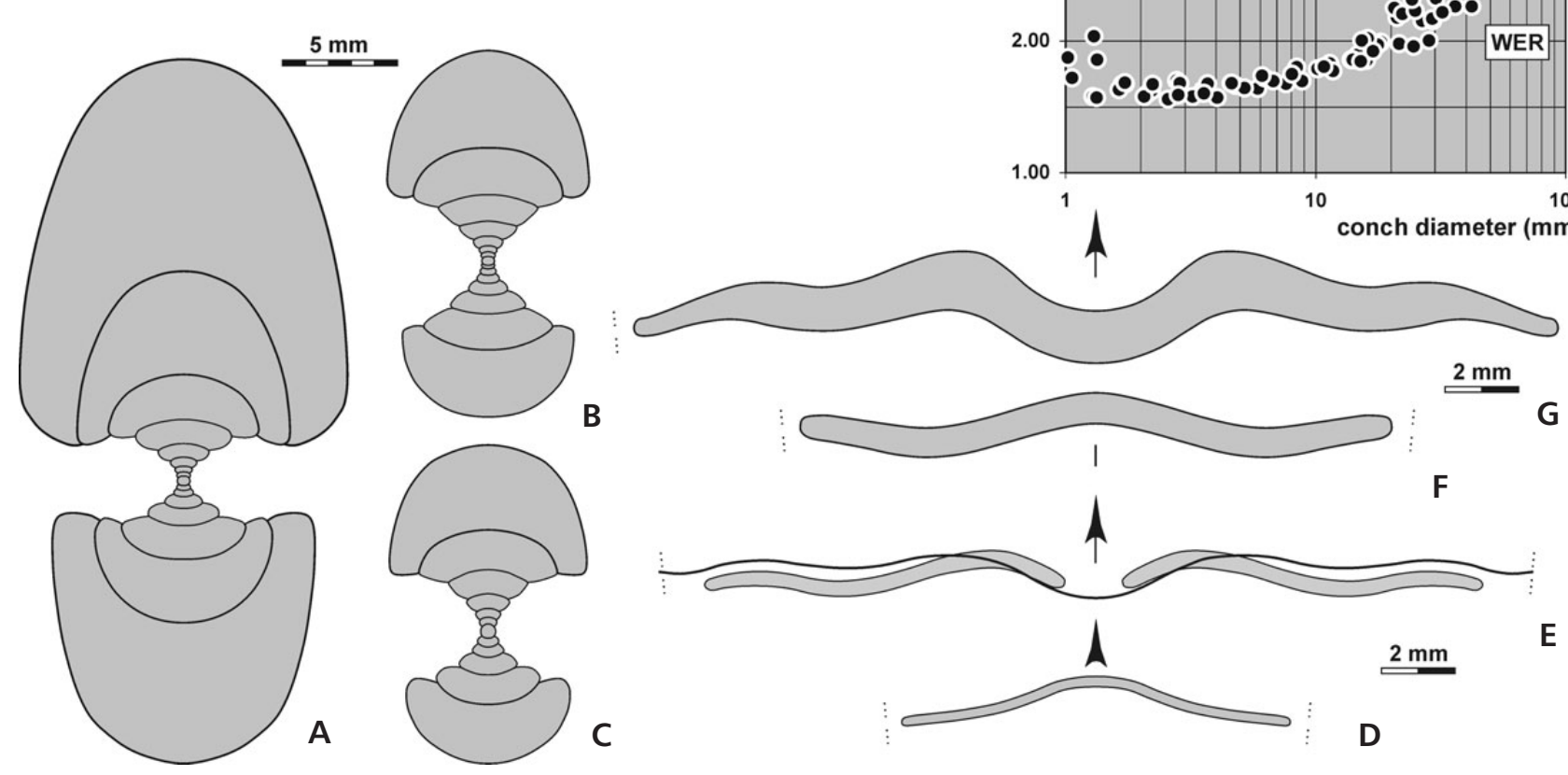

Figure 27. Girtyoceras primum sp. nov. • A - cross section of paratype UMNH IP 2834 from bed 16 (sample 00UTMI-1n) of Needle Range; $\times 2.5$. - B - cross section of paratype UMNH IP 2836 from bed 16 (sample 00UTMI-1n) of Needle Range; $\times 2.5$. $\bullet$ C cross section of paratype UMNH IP 2837 from bed 16 (sample 00UTMI-1n) of Needle Range; $\times 2.5$. $\bullet$ D - constriction course of paratype UMNH IP 2953 from bed 25 (sample 05UTJU-12) of Granite Mountain South, at $8.0 \mathrm{~mm}$ ww, $4.7 \mathrm{~mm}$ wh; $\times 4.0$. $\bullet$ E - growth line and constriction course of paratype UMNH IP 2951 from bed 25 (sample 05UTJU-12) of Granite Mountain South, at $11.2 \mathrm{~mm}$ ww, $8.8 \mathrm{~mm}$ wh; $\times 4.0$. $\bullet \mathrm{F}$ - constriction course of paratype UMNH IP 2952 from bed 25 (sample 05UTJU-12) of Granite Mountain South, at $10.4 \mathrm{~mm} \mathrm{ww}, 10.3 \mathrm{~mm}$ wh; $\times 4.0$. $\bullet$ G, constriction course of paratype UMNH IP 2952 from bed 25 (sample 05UTJU-12) of Granite Mountain South, at $24.9 \mathrm{~mm}$ diameter, $12.3 \mathrm{~mm}$ ww, $14.0 \mathrm{~mm}$ wh; $\times$ 4.0. $\bullet \mathrm{H}$ - suture line of paratype UMNH IP 2953 from bed 25 (sample 05UTJU-12) of Granite Mountain South, at $8.0 \mathrm{~mm}$ ww, $4.7 \mathrm{~mm}$ wh; $\times 5.0$. • I - suture line of paratype UMNH IP 2952 from bed 25 (sample 05UTJU-12) of Granite Mountain South, at $10.4 \mathrm{~mm}$ ww, $10.3 \mathrm{~mm} \mathrm{wh} \times 5.0$. $・$ J - suture line of paratype UMNH IP 2952 from bed 25 (sample 05UTJU-12) of Granite Mountain South, at $26.5 \mathrm{~mm}$ diameter, $12.5 \mathrm{~mm}$ ww, $14.3 \mathrm{~mm}$ wh; $\times 5.0$. $\bullet \mathrm{K}-\mathrm{M}-$ ontogenetic development of the conch width index (ww/dm), umbilical width index (uw/dm), whorl width index (ww/wh), and whorl expansion rate (WER) of all available specimens.

discus-shaped body chamber is crushed but it is clear that the conch is oxyconic with a sharp venter by $40 \mathrm{~mm}$ diameter. Only some shell remains are preserved at this diameter; they show fine biconvex growth lines. There are no constrictions.
Holotype UMNH IP 2865 is a fully septate conch with $42 \mathrm{~mm}$ diameter and shows the transformation into the adult oxyconic stage; the venter becomes sharpe at $30 \mathrm{~mm}$ diameter (Fig. 26C). The lenticular conch $(\mathrm{ww} / \mathrm{dm}=0.34)$ 
Table 11. Conch dimensions (in $\mathrm{mm}$ ) and proportions for reference specimens of Girtyoceras primum sp. nov.

\begin{tabular}{|c|c|c|c|c|c|c|c|c|c|c|}
\hline & $\mathrm{dm}$ & ww & wh & uw & $\mathrm{ah}$ & ww/dm & ww/wh & uw/dm & WER & IZR \\
\hline HT UMNH IP 2865 & 42.1 & 14.3 & 23.1 & 5.2 & 14.1 & 0.34 & 0.62 & 0.12 & 2.26 & 0.39 \\
\hline PT UMNH IP 2834 & 32.1 & 14.3 & 18.8 & 2.3 & 10.5 & 0.44 & 0.76 & 0.07 & 2.22 & 0.44 \\
\hline PT UMNH IP 2952 & 29.3 & 12.9 & 15.2 & 5.8 & 9.4 & 0.44 & 0.85 & 0.20 & 2.17 & 0.38 \\
\hline PT UMNH IP 2864 & 25.0 & 9.9 & 13.2 & 4.1 & 8.3 & 0.40 & 0.75 & 0.16 & 2.23 & 0.37 \\
\hline PT UMNH IP 3084 & 17.7 & 9.9 & 8.6 & 3.8 & 5.1 & 0.56 & 1.15 & 0.22 & 1.97 & 0.41 \\
\hline PT UMNH IP 2836 & 16.0 & 8.8 & 6.4 & 5.6 & 4.2 & 0.55 & 1.37 & 0.35 & 1.85 & 0.34 \\
\hline PT UMNH IP 2953 & 15.1 & 8.9 & 7.2 & 3.4 & 4.0 & 0.59 & 1.24 & 0.22 & 1.85 & 0.44 \\
\hline PT UMNH IP 2837 & 13.9 & 8.6 & 5.7 & 4.5 & 3.7 & 0.62 & 1.51 & 0.33 & 1.86 & 0.35 \\
\hline
\end{tabular}

has a narrow umbilicus (uw/dm $=0.12$ ) with a narrowly rounded umbilical margin. Shell remains show biconvex growth lines; neither shell surface nor the internal mould possesses constrictions.

Constrictions of the internal mould are preserved in smaller specimens such as paratype UMNH IP 2954. This specimen from Granite Mountain has a diameter of $36 \mathrm{~mm}$ and closely resembles the holotype in conch parameters and shell ornament.

The well-preserved paratype UMNH IP 2952 is fully septate and almost $30 \mathrm{~mm}$ in diameter (Fig. 26B). It shows steinkern constrictions $90^{\circ}$ apart. The first of these is barely visible; the other three show a change in their course from prorsiradiate with a ventral projection to a biconvex course with a ventral sinus (Fig. 27F, G). Conch ratios of the specimen are $\mathrm{ww} / \mathrm{dm}=0.44$, uw/dm $=0.20$.

Paratype UMNH IP 3084 has a diameter of $18 \mathrm{~mm}$ and is partly covered with shell (Fig. 26E). The growth lines are fine and extend almost linearly across flanks and venter. Some weak spiral lines can be seen on the venter. Rather deep, irregularly arranged steinkern constrictions are slightly prorsiradiate with a shallow ventral projection; they are much weaker on the shell surface.

Two suture lines were drawn from paratype UMNH IP 2952 (Fig. 27I, J). At $26.5 \mathrm{~mm}$ diameter, there is a wide external lobe with slightly sinuous flanks and a median saddle that reaches almost half the height of the external lobe depth. The ventrolateral saddle is slightly asymmetric and rounded, on the flank followed by an asymmetric adventive lobe that is much smaller than the external lobe.

Discussion. - Girtyoceras primum differs from other girtyoceratids in the Chainman Formation in the following: the two Calygirtyoceras species have a much wider conch (ww/dm $=0.60$ at $20 \mathrm{~mm} \mathrm{dm}$ in contrast to 0.45 in G. primum) and a distinct calyx stage with an angular ventrolateral edge. G. primum may sometimes show tendencies to also show such juvenile stage, but always has a much more rounded ventrolateral edge. However, it is obvious G. primum holds a phylogenetic position close to Calygirtyoce- ras, as indicated by the presence of prorsiradiate, ventrally projecting constrictions in juveniles.

The constrictions of $G$. primum show only moderately high ventrolateral projection, and this can be used to readily separate it from the stratigraphically younger species $G$. gordoni, G. hamiltonense, and G. meslerianum (Girty, 1909) from North America. G. endicottense Gordon, 1957 is a similar species, but differs in the more slender conch at comparable diameters and in presence of a ventral groove.

Species of similar stratigraphic age from Europe are G. excavatum, G. simplex, G. premeslerianum, and $G$. ibergense; they differ from $G$. primum mainly in the more slender conch, the slightly narrower umbilicus, and the biconvex constrictions in the intermediate growth stage.

The stratigraphically younger European species G. brueningianum (Schmidt, 1925), G. goii Korn, 1988, and G. margaritatum Korn, 1988 have a similar conch shape, but show, in the juvenile stage, a ventral sinus of the constrictions, in contrast to the ventral projection in G. primum.

\section{Girtyoceras gordoni sp. nov.}

Figures 28, 29

Derivation of name. - Named after Mackenzie Gordon Jr., to honour his contributions to Carboniferous ammonoid palaeontology.

Holotype. - Specimen UMNH IP 3093, illustrated in Fig. 28A.

Type locality and horizon. - South Burbank Hills, bed 16; Camp Canyon Member of Chainman Formation, Girtyoceras gordoni Biozone.

Material. - The holotype and 26 paratypes; conch diameter up to $21 \mathrm{~mm}$.

Diagnosis. - Species of Girtyoceras with a pachyconic, widely umbilicate conch at 6-8 $\mathrm{mm}$ diameter $(\mathrm{ww} / \mathrm{dm}=$ $0.70-0.80 ; \mathrm{uw} / \mathrm{dm}=0.55-0.60)$, and a thickly discoidal, 

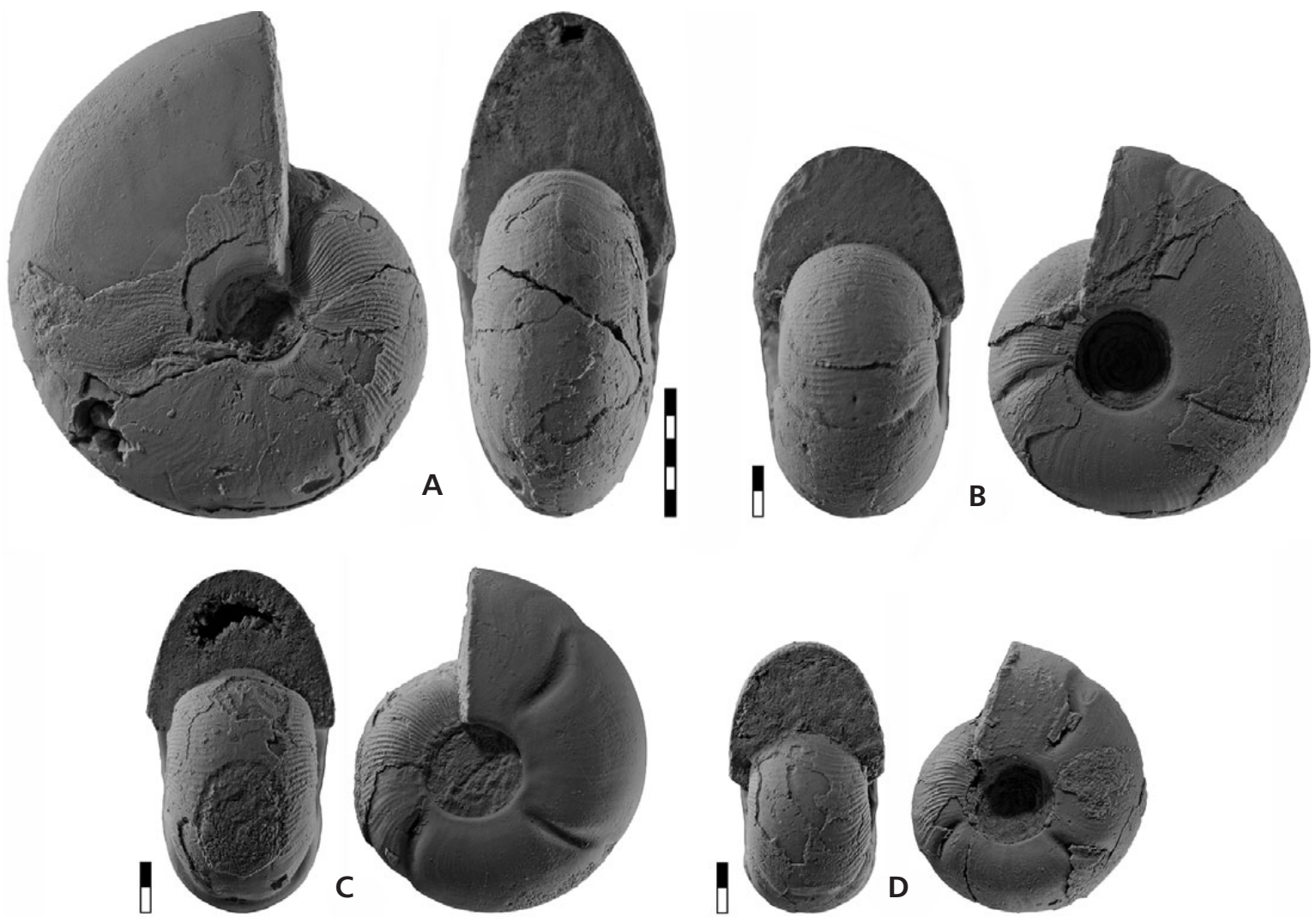

Figure 28. Girtyoceras gordoni sp. nov. • A - holotype UMNH IP 3093 from bed 16 (sample 01UTMI-4) of South Burbank Hills; $\times 3.0$. $\bullet$ B - paratype UMNH IP 3102 from bed, 19 (sample 97UTMI-13) of Jensen Wash; × 3.0. • C - paratype UMNH IP 3094 from bed 16 (sample 01 UTMI-4) of South Burbank Hills; $\times 3.0$. • D - paratype UMNH IP 3095 from bed 16 (sample 01UTMI-4) of South Burbank Hills; $\times 3.0$.

narrowly umbilicate conch at $20 \mathrm{~mm}$ diameter $(\mathrm{ww} / \mathrm{dm}=$ $0.45-0.50 ; \mathrm{uw} / \mathrm{dm}=0.15-0.20)$. Whorl cross section extremely depressed in juveniles (2-6 mm diameter), followed by an intermediate stage with rounded venter and angular umbilical margin (above $7 \mathrm{~mm}$ diameter), and a discoidal stage (20 mm diameter) with narrowly rounded venter. Ornament with coarse prorsiradiate growth lines in all stages up to $20 \mathrm{~mm}$ conch diameter, their course is concavoconvex in juveniles and biconvex in later stages. Strong shell constrictions in intermediate growth stages.

Description. - The two sectioned paratypes UMNH IP 3103 and UMNH IP 3096 (Fig. 29A, B) are similar but differ in details such as the width of the whorls (UMNH IP 3103 has wider whorls), the height of the aperture (higher in UMNH IP 3096), and the umbilical margin (more angular in UMNH IP 3103). Both specimens display the typical significant ontogenetic changes, with a serpenticonic initial stage up to 1.5-2 mm diameter, followed by a stage in which the whorl width increases rapidly to form a broadtrapezoidal whorl cross section. Opening of the umbilicus occurs up to $8 \mathrm{~mm}$ conch diameter, thereafter it maintains its absolute width (Fig. 29E-G). The umbilical margin is subangular in this stage and the whorl cross section is semi- lunate. In later stages, the whorls become laterally compressed with a higher aperture, resulting in a higher whorl expansion rate that exceeds the value of 2.00 at $18 \mathrm{~mm}$ conch diameter.

None of the specimens shows an oxyconic adult stage. Holotype UMNH IP 3093, at $20 \mathrm{~mm}$ conch diameter, is the largest of the well-preserved specimens (Fig. 28A); it is discoidal $(\mathrm{ww} / \mathrm{dm}=0.45)$ with a narrow umbilicus $(\mathrm{uw} / \mathrm{dm}=0.16)$ and has a narrowly rounded venter with a barely visible keel. It can be assumed therefore that this specimen is close to the beginning of the adult conch. The last quarter of the last volution is a part of the body chamber; its internal mould displays an undulation with delicate biconvex traces of strengthened growth lines. The chambered portion shows three continuously weakening constrictions, which are best seen on the internal mould. The coarse growth lines extend with biconvex course across flanks and venter, forming a low dorsolateral projection, a prominent ventrolateral projection, and a shallow ventral sinus.

Paratype UMNH IP 3095 is characteristic for the intermediate growth stage (Fig. 28B). It has a diameter of $13.5 \mathrm{~mm}$ and is thickly discoidal $(\mathrm{ww} / \mathrm{dm}=0.53)$ with a narrow umbilicus $(\mathrm{uw} / \mathrm{dm}=0.26$ ). The flanks and venter 
Figure 29. Girtyoceras gordoni sp. nov. - A - cross section of paratype UMNH IP 3103 from bed 19 (sample 97UTMI-13) of Jensen Wash; $\times 2.5$. - B - cross section of paratype UMNH IP 3096 from bed 16 (sample 01UTMI-4) of South Burbank Hills; $\times 2.5$. $-\mathrm{C}-$ constriction course of paratype UMNH IP 3095 from bed 16 (sample 01UTMI-4) of South Burbank Hills, at $12.4 \mathrm{~mm}$ diameter, $6.9 \mathrm{~mm} \mathrm{ww}$, $5.3 \mathrm{~mm} \mathrm{wh} ; \times 5.0$. $・ \mathrm{D}$ - suture line of paratype UMNH IP 3101 from bed, 19 (sample 97UTMI-13) of Jensen Wash, at $8.1 \mathrm{~mm}$ ww, $6.9 \mathrm{~mm} \mathrm{wh;} \times 5.0$. - E-G - ontogenetic development of the conch width index (ww/dm), umbilical width index (uw/dm), whorl width index (ww/wh), and whorl expansion rate (WER) of all available specimens.

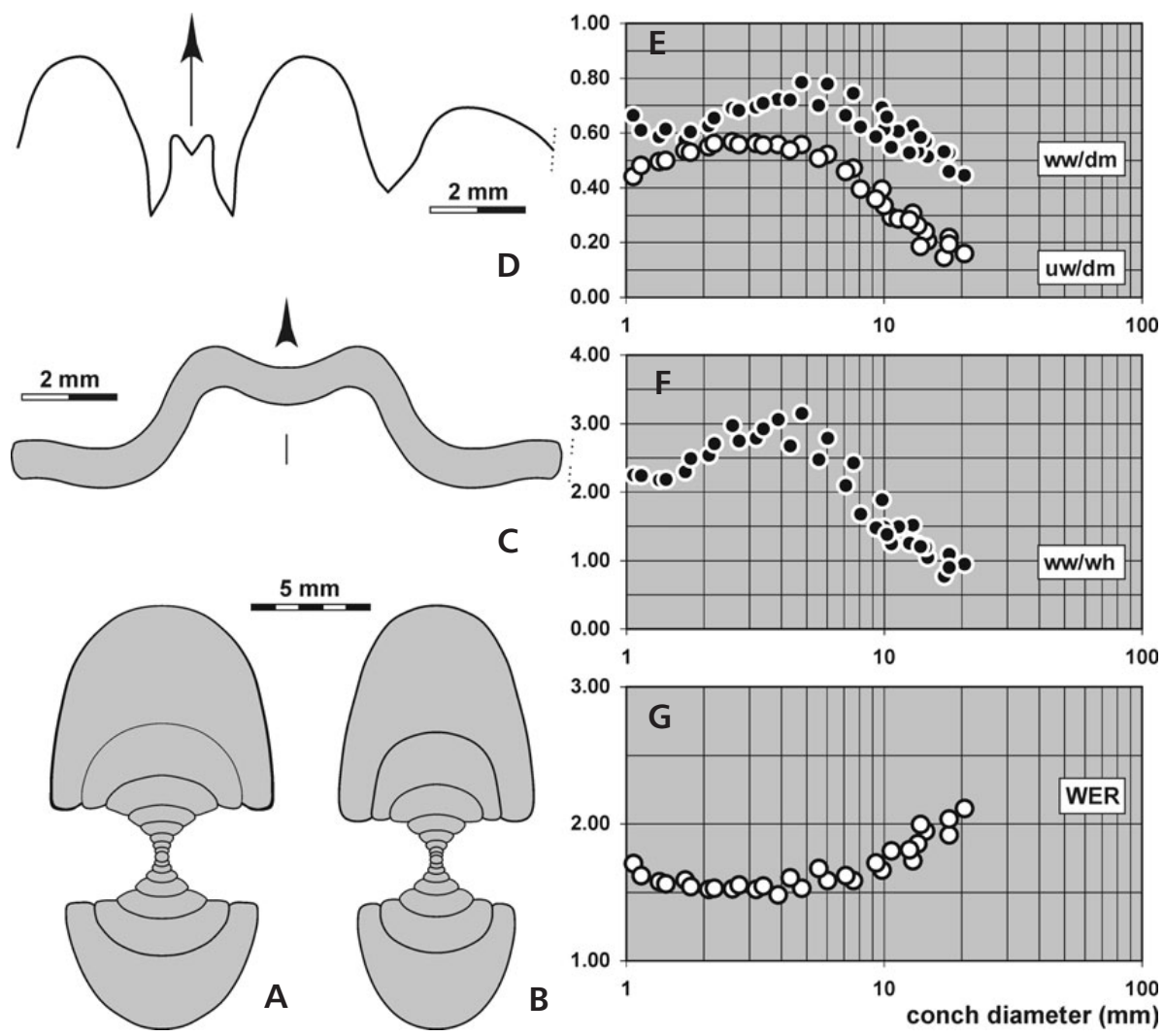

Table 12. Conch ontogeny (Fig. 29) of Girtyoceras gordoni sp. nov.

\begin{tabular}{|c|c|c|c|}
\hline $\mathrm{dm}$ & conch shape & whorl cross section shape & aperture \\
\hline $1.5 \mathrm{~mm}$ & $\begin{array}{l}\text { thinly pachyconic; evolute } \\
(\mathrm{ww} / \mathrm{dm}=0.60-0.65 ; \mathrm{uw} / \mathrm{dm}=0.50-0.55)\end{array}$ & $\begin{array}{l}\text { strongly depressed; moderately embracing }(\mathrm{ww} / \mathrm{wh}=2.15-2.25 \\
\mathrm{IZR}=0.20-0.25)\end{array}$ & low $($ WER $\sim 1.55)$ \\
\hline $5 \mathrm{~mm}$ & $\begin{array}{l}\text { thickly pachyconic; evolute } \\
(\mathrm{ww} / \mathrm{dm}=0.70-0.80 ; \mathrm{uw} / \mathrm{dm}=0.50-0.55)\end{array}$ & $\begin{array}{l}\text { extremely depressed; moderately embracing }(\mathrm{ww} / \mathrm{wh}=2.70-3.20 \\
\mathrm{IZR}=0.20-0.25)\end{array}$ & low $($ WER 1.55) \\
\hline $10 \mathrm{~mm}$ & $\begin{array}{l}\text { thinly pachyconic; subevolute } \\
(\mathrm{ww} / \mathrm{dm}=0.60-0.65 ; \mathrm{uw} / \mathrm{dm}=0.35-0.40)\end{array}$ & $\begin{array}{l}\text { moderately depressed; strongly embracing }(\mathrm{ww} / \mathrm{wh}=1.50-1.90 \\
\mathrm{IZR} \sim 0.40)\end{array}$ & low $($ WER 1.70) \\
\hline $20 \mathrm{~mm}$ & $\begin{array}{l}\text { thinly discoidal; subinvolute } \\
\text { (ww/dm } \sim 0.45 ; \mathrm{uw} / \mathrm{dm} \sim 0.16 \text { ) }\end{array}$ & $\begin{array}{l}\text { weakly compressed; strongly embracing (ww/wh } \sim 0.95 \\
\text { IZR } ~ 0.40 \text { ) }\end{array}$ & high (WER 2.10) \\
\hline
\end{tabular}

Table 13. Conch dimensions (in $\mathrm{mm}$ ) and proportions for reference specimens of Girtyoceras gordoni sp. nov.

\begin{tabular}{|c|c|c|c|c|c|c|c|c|c|c|}
\hline & $\mathrm{dm}$ & ww & wh & uw & $\mathrm{ah}$ & ww/dm & ww/wh & uw/dm & WER & IZR \\
\hline HT UMNH IP 3093 & 20.5 & 9.1 & 9.6 & 3.3 & 6.4 & 0.45 & 0.95 & 0.16 & 2.11 & 0.34 \\
\hline PT UMNH IP 3103 & 17.9 & 9.5 & 8.6 & 3.9 & 5.0 & 0.53 & 1.09 & 0.22 & 1.92 & 0.42 \\
\hline PT UMNH IP 3096 & 17.9 & 8.2 & 9.1 & 3.5 & 5.3 & 0.46 & 0.90 & 0.19 & 2.04 & 0.41 \\
\hline PT UMNH IP 3101 & 17.1 & 9.1 & 11.8 & 2.5 & - & 0.53 & 0.77 & 0.15 & - & - \\
\hline PT UMNH IP 3102 & 14.5 & 8.3 & 6.9 & 3.5 & 4.1 & 0.57 & 1.20 & 0.24 & 1.95 & 0.41 \\
\hline PT UMNH IP 3095 & 13.5 & 7.2 & 5.8 & 3.6 & 3.6 & 0.53 & 1.24 & 0.26 & 1.85 & 0.38 \\
\hline PT UMNH IP 3094 & 10.7 & 5.8 & 4.7 & 3.1 & 2.7 & 0.55 & 1.24 & 0.29 & 1.80 & 0.42 \\
\hline
\end{tabular}

are broadly rounded, and the umbilical margin is angular. The specimen shows deep constrictions on the internal mould, which form prominent ventrolateral projections and shallow ventral sinuses (Fig. 29C).
The inner whorls of paratype UMNH IP 3104 are trapezoidal in cross section and possess a sharp umbilical wall ornamented by faint nodes. At this stage, the umbilicus is wide and the venter is flattened. 
Table 14. Conch ontogeny (Fig. 31) of Girtyoceras hamiltonense sp. nov.

\begin{tabular}{|c|c|c|c|}
\hline $\mathrm{dm}$ & conch shape & whorl cross section shape & aperture \\
\hline $1.5 \mathrm{~mm}$ & $\begin{array}{l}\text { thickly discoidal; evolute } \\
(\mathrm{ww} / \mathrm{dm}=0.50-0.60 ; \mathrm{uw} / \mathrm{dm}=0.45-0.50)\end{array}$ & $\begin{array}{l}\text { moderately depressed; moderately embracing } \\
(\mathrm{ww} / \mathrm{wh}=1.80-2.00 ; \mathrm{IZR}=0.20-0.25)\end{array}$ & low $($ WER 1.60) \\
\hline $5 \mathrm{~mm}$ & $\begin{array}{l}\text { thinly pachyconic; evolute } \\
(\mathrm{ww} / \mathrm{dm}=0.60-0.70 ; \mathrm{uw} / \mathrm{dm}=0.45-0.55)\end{array}$ & $\begin{array}{l}\text { strongly depressed; moderately embracing } \\
(\mathrm{ww} / \mathrm{wh}=2.10-2.50 ; \mathrm{IZR}=0.25-0.30)\end{array}$ & low $($ WER $=1.55-1.65)$ \\
\hline $10 \mathrm{~mm}$ & $\begin{array}{l}\text { thickly discoidal; subevolute } \\
(\mathrm{ww} / \mathrm{dm}=0.55-0.60 ; \mathrm{uw} / \mathrm{dm}=0.30-0.35)\end{array}$ & $\begin{array}{l}\text { weakly depressed; strongly embracing } \\
(\mathrm{ww} / \mathrm{wh}=1.25-1.50 ; \mathrm{IZR}=0.35-0.40)\end{array}$ & moderate $($ WER $=1.65-1.75)$ \\
\hline $25 \mathrm{~mm}$ & $\begin{array}{l}\text { thinly discoidal; involute } \\
\text { (ww/dm } \sim 0.38 ; \text { uw/dm } \sim 0.12 \text { ) }\end{array}$ & $\begin{array}{l}\text { weakly compressed; strongly embracing }(\mathrm{ww} / \mathrm{wh}=0.70 \\
\text { IZR } \sim 0.40)\end{array}$ & high (WER 2.05) \\
\hline $55 \mathrm{~mm}$ & $\begin{array}{l}\text { extremely discoidal; involute } \\
\text { (ww/dm } \sim 0.25 ; \mathrm{uw} / \mathrm{dm} \sim 0.05)\end{array}$ & $\begin{array}{l}\text { strongly compressed; strongly embracing (ww/wh } \sim 0.45 \text {; } \\
\text { IZR 0.40) }\end{array}$ & very high $($ WER 2.45) \\
\hline
\end{tabular}

The suture line of paratype UMNH IP 3101 has the typical outline of the genus (Fig. 29D). The V-shaped external lobe has slightly curved flanks and a median saddle of almost half the height of the external lobe. The adventive lobe is much smaller and V-shaped.

Discussion. - Girtyoceras gordoni is very similar to $G$. hamiltonense, but juveniles of the former have a more angular umbilical edge and growth lines and constrictions in the thickly discoidal, strongly sulcated 'sulcatum stage' (biconvex in $G$. gordoni, concavo-convex in G. hamiltonense). Also, constrictions of G. hamiltonense persist until the venter is acute, whereas in G. gordoni, they disappear earlier, when the venter is rounded.

The new species has a stouter conch $(\mathrm{ww} / \mathrm{dm}=0.45$ at $20 \mathrm{~mm}$ diameter) than $G$. meslerianum $(\mathrm{ww} / \mathrm{dm}=$ 0.40 ) and a less angular umbilical margin. The growth lines are stronger in G. gordoni, a criterion that distinguishes the species also from other advanced species of the genus.

Girtyoceras hamiltonense sp. nov.

Figures 30, 31

1949 Girtyoceras aff. G. meslerianum (Girty 1911); Miller et al., p. 608, pl. 99, figs 9, 10.

1970 Girtyoceras meslerianum (Girty); Gordon, p. 821.

1984 Girtyoceras meslerianum (Girty); Webster et al., p. 31.

Derivation of name. - Named for Hamilton Canyon, Nevada, source of the type specimens.

Holotype. - Specimen UMNH IP 3127, illustrated in Fig. 30B.

Type locality and horizon. - Hamilton Canyon, bed 44; Camp Canyon Member of Chainman Formation, Goniatites eganensis Biozone.
Material. - The holotype and 106 paratypes; conch diameter up to $54 \mathrm{~mm}$.

Diagnosis. - Species of Girtyoceras with a pachyconic, widely umbilicate conch at $6-8 \mathrm{~mm}$ diameter $(\mathrm{ww} / \mathrm{dm}=$ $0.62-0.72 ; \mathrm{uw} / \mathrm{dm}=0.45-0.55$ ), and a thickly discoidal, very narrowly umbilicate conch at $20 \mathrm{~mm}$ diameter $(\mathrm{ww} / \mathrm{dm}=0.40-0.45 ; \mathrm{uw} / \mathrm{dm}=0.10-0.15)$. Whorl cross section strongly depressed in juveniles (2-6 mm diameter), followed by an intermediate stage with rounded venter and angular umbilical margin (above $7 \mathrm{~mm}$ diameter), and a discoidal stage (20 $\mathrm{mm}$ diameter) with narrowly rounded venter. Ornament with coarse prorsiradiate growth lines in all stages, their course is concavo-convex in juveniles and the intermediate stage and biconvex in later stages. Strong shell constrictions in intermediate growth stages.

Description. - Cross sections made from the type suite are all similar allowing for accurate characterization of the ontogenetic trajectories of the species (Fig. 31A-D). Five stages of conch ontogeny can be separated, (1) a serpenticonic initial stage, (2) the 'calyx stage' with pronounced umbilical edge that separates the oblique umbilical wall from the almost flat venter, (3) the 'sulcatum stage', in which the whorl cross section is crescent-shaped, (4) the "excavatum stage' (the stage with strongly curved constrictions) with lateral flattening of the conch and stagnation of umbilical opening, and (5) the 'discus stage', in which the conch becomes lenticular with an acute venter. These transformations cause significant changes in the ww/dm, uw/dm, and WER plots, as illustrated in Fig. 31G-I.

Paratype UMNH IP 3188 is a fully mature phragmocone with a diameter of $54 \mathrm{~mm}$ (Fig. 30A). The conch is disc-shaped $(\mathrm{ww} / \mathrm{dm}=0.27)$ with a very narrow umbilicus (uw/dm $=0.06$ ). The venter is subacute in the first quarter of the last whorl and acute thereafter. The specimen has a high aperture with a whorl expansion rate of 2.48. Attached shell remains are almost smooth except for delicate growth lines that form a prominent ventrolateral projection. Faint nodes are preserved on the 
Figure 30. Girtyoceras hamiltonense sp. nov. $-\mathrm{A}$ - paratype UMNH IP 3188 from bed 44 (sample 95NVWP-16) of Hamilton Canyon; $\times 1.0 \cdot \bullet \mathrm{B}-$ holotype UMNH IP 3127 from bed 44 (sample 07NVWP-3) of Hamilton Canyon; $\times 1.5$. $\bullet$ - paratype MB.C.12005.1 from bed 44 of Hamilton Canyon; $\times 3.0$. $\bullet \mathrm{D}-$ paratype UMNH IP 3120 from bed 25 (sample 01UTMI-5) of South Burbank Hills; $\times 3.0$.
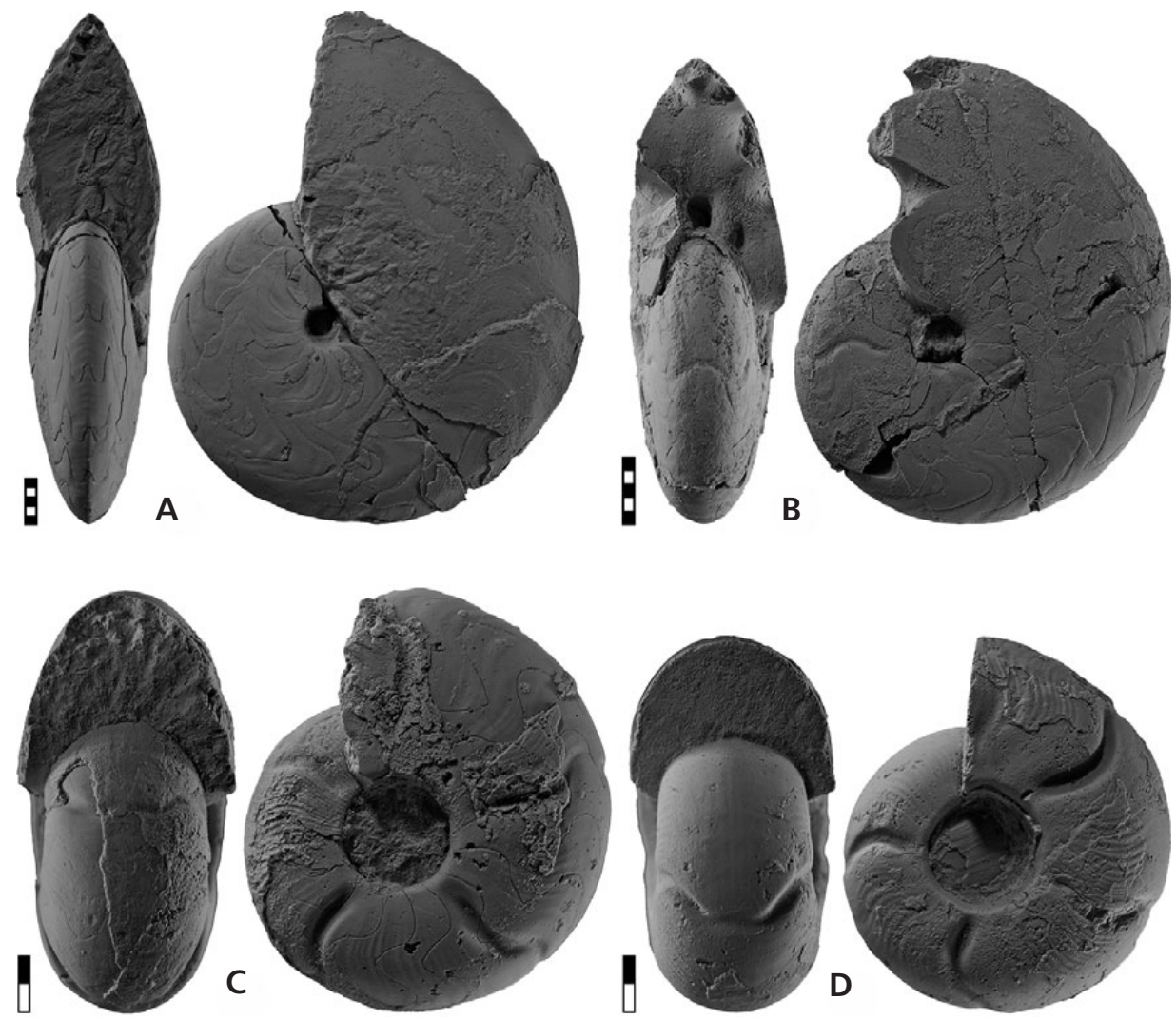

acute venter. The internal mould is smooth except for impressions of rhythmically strengthened growth lines.

The transition from the preadult to the adult stage is best seen in the holotype UMNH IP 3127 (Fig. 30B). It has $33 \mathrm{~mm}$ diameter and is lenticular $(\mathrm{ww} / \mathrm{dm}=0.34)$ with a very narrow umbilicus ( $\mathrm{uw} / \mathrm{dm}=0.08$ ) and a high aperture (WER $=2.42$ ). The last whorl of the entirely septate specimen begins with a rounded venter, which transforms into an acute shape by the end of the whorl. One biconvex constriction is visible on the internal mould; they completely disappear as the venter becomes sharply angular.

Paratype MB.C.12005.1 (15 mm diameter) represents an intermediate growth stage, where the discoidal conch (ww/dm $=0.49$ ) begins to flatten and the umbilicus begins to close $(\mathrm{uw} / \mathrm{dm}=0.23)$. The specimen shows a coarse shell ornament with concavo-convex growth lines and deep radial constrictions following the growth lines in their course (Fig. 30C). A ventrolateral projection begins to develop at about $14 \mathrm{~mm}$ diameter. The constrictions are stronger on the internal mould, where the growth lines are also impressed (Fig. 31E).

Smaller specimens like paratype UMNH IP 3120 (13 $\mathrm{mm}$ diameter) are thickly discoidal $(\mathrm{ww} / \mathrm{dm}=0.53)$ and possess a moderately wide umbilicus (uw/dm $=0.29$ ). This specimen is an internal mould, on which there are five pronounced concavo-convex constrictions and impressed growth lines (Fig. 30D). Constrictions are concave on the flanks; they turn forward to form a prominent ventrolateral projection and a shallow external sinus.

Suture lines show the course that is characteristic for a Girtyoceras species. The adult paratype UMNH IP 3188 has, at $36 \mathrm{~mm}$ diameter, a wide external lobe with strongly diverging flanks, an asymmetric ventrolateral saddle, and an asymmetric adventive lobe with a strongly curved dorsal flank (Fig. 31F).

Discussion. - For a comparison with the similar species G. gordoni, see above under that species. Girtyoceras meslerianum is also similar, but has a more compressed conch and wider umbilicus (uw/dm $=0.30$ at $15 \mathrm{~mm} \mathrm{dm}$ ). The course of the constrictions, which are, in the intermediate stage, strongly bent forward in the new species, is the main difference from European species such as G. ibergense, G. brueningianum, G. goii, G. deani, and G. excavatum.

Superfamily Dimorphocerataceae Hyatt, 1884 Family Dimorphoceratidae Hyatt, 1884

Family definition. - Dimorphocerataceae with a high, parallel-sided median saddle.

Included subfamilies. - Dimorphoceratinae Hyatt, 1884; Glyphiolobinae Ruzhencev \& Bogoslovskaya, 1969. 

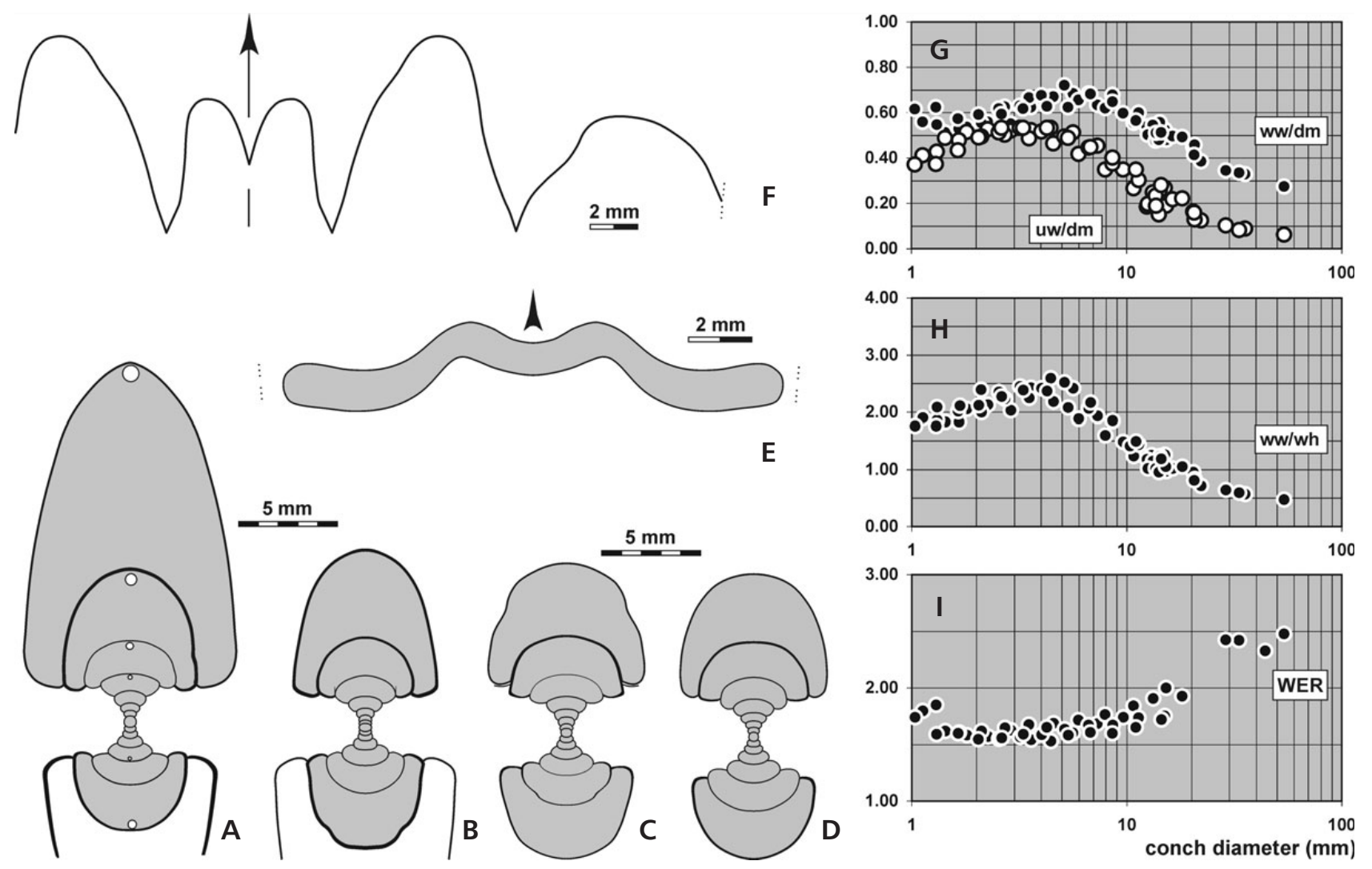

Figure 31. Girtyoceras hamiltonense sp. nov. $\bullet$ A - cross section of paratype MB.C.12005.2 from bed 44 of Hamilton Canyon; $\times 2.5$. $\bullet$ B - cross section of paratype MB.C.12005.3 from bed 44 of Hamilton Canyon; $\times 2.5$. C - cross section of paratype UMNH IP 3128 from bed 44 (sample 07NVWP-3) of Hamilton Canyon; $\times 2.5 . \bullet$ D - cross section of paratype UMNH IP 3150 from bed $25($ sample 07UTMI-1) of South Burbank Hills; $\times 2.5$. $\bullet$ E - constriction course of paratype MB.C.12005.1 from bed 44 of Hamilton Canyon, at $14.5 \mathrm{~mm}$ diameter, $7.0 \mathrm{~mm}$ ww, $6.7 \mathrm{~mm}$ wh; $\times 4.0$. $\bullet \mathrm{F}-\mathrm{suture}$ line of paratype UMNH IP 3188 from bed 44 (sample 99NVWP-15) of Hamilton Canyon, at $35.7 \mathrm{~mm}$ diameter, $11.0 \mathrm{~mm}$ ww, 21.2 mm wh; $\times 3.0$. $\bullet$ G-I - ontogenetic development of the conch width index (ww/dm), umbilical width index (uw/dm), whorl width index (ww/wh), and whorl expansion rate (WER) of all available specimens.

Table 15. Conch dimensions (in $\mathrm{mm}$ ) and proportions for reference specimens of Girtyoceras hamiltonense sp. nov.

\begin{tabular}{|c|c|c|c|c|c|c|c|c|c|c|}
\hline & $\mathrm{dm}$ & ww & wh & uw & ah & ww/dm & ww/wh & $\mathrm{uw} / \mathrm{dm}$ & WER & IZR \\
\hline PT UMNH IP 3188 & 53.9 & 14.8 & 31.1 & 3.4 & 19.7 & 0.27 & 0.47 & 0.06 & 2.48 & 0.37 \\
\hline HT UMNH IP 3127 & 33.2 & 11.1 & 18.7 & 2.8 & 11.9 & 0.34 & 0.60 & 0.08 & 2.42 & 0.37 \\
\hline PT MB.C.12005.3 & 15.2 & 7.3 & 7.5 & 2.9 & 4.5 & 0.48 & 0.98 & 0.19 & 2.00 & 0.41 \\
\hline PT MB.C.12005.1 & 15.2 & 7.4 & 7.1 & 3.4 & 4.3 & 0.49 & 1.05 & 0.23 & 1.93 & 0.40 \\
\hline PT UMNH IP 3128 & 15.0 & 7.9 & 6.2 & 4.0 & 3.7 & 0.53 & 1.26 & 0.27 & 1.75 & 0.41 \\
\hline PT UMNH IP 3150 & 14.5 & 7.4 & 6.2 & 4.0 & 3.4 & 0.51 & 1.19 & 0.28 & 1.72 & 0.45 \\
\hline PT MB.C.12005.2 & 13.3 & 6.8 & 6.2 & 3.2 & 3.7 & 0.51 & 1.09 & 0.24 & 1.91 & 0.41 \\
\hline PT UMNH IP 3120 & 13.1 & 6.9 & 5.5 & 3.8 & 3.7 & 0.53 & 1.25 & 0.29 & 1.93 & 0.33 \\
\hline
\end{tabular}

Subfamily Dimorphoceratinae Hyatt, 1884

Subfamily definition. - Dimorphoceratidae with an unsubdivided adventive lobe.

Included genera. - Dimorphoceras Hyatt, 1884; Trizonoceras Girty, 1909; Asturoceras Ruzhencev \& Bogoslovskaya, 1969.

\section{Genus Dimorphoceras Hyatt, 1884}

Type species. - Goniatites Gilbertsoni Phillips, 1836 (subsequent designation by Foord \& Crick 1897).

Genus definition. - Dimorphoceratinae with an external lobe, in which both secondary prongs are subdivided into two large tertiary lobes. 
Included species. - algens: Dimorphoceras algens Gordon, 1957, p. 55; Alaska; brancoi: Dimorphoceras Brancoi Holzapfel, 1889, p. 38; Rhenish Mountains; dnieperense: Dimorphoceras dnieperense Kusina, 1991, p. 41; Donets Basin; gilbertsoni: Goniatites Gilbertsoni Phillips, 1836, p. 236; Lancashire; holzapfeli: Dimorphoceras Holzapfeli Haug, 1898, p. 109; Rhenish Mountains [synonym of D. brancoi]; kathleenae: Dimorphoceras kathleeni Moore, 1936, p. 190; Lancashire; leagramense: Dimorphoceras leagramense Riley, 1996, p. 22; Lancashire; rileyi: Dimorphoceras rileyi sp. nov.; Antler Foreland Basin; worki: Dimorphoceras worki sp. nov.; Antler Foreland Basin.

\section{Dimorphoceras worki sp. nov.}

Figures 32, 33C

Derivation of name. - After David Work, to honour his contributions to Carboniferous ammonoid palaeontology.

Holotype. - Specimen UMNH IP 3229, illustrated in Fig. 32.

Type locality and horizon. - South Burbank Hills, bed 4; Camp Canyon Member of Chainman Formation, Calygirtyoceras arcticum Biozone.

Material. - Only the holotype; conch diameter $36 \mathrm{~mm}$ but fully septate.

Diagnosis. - Species of Dimorphoceras with a discoidal conch $(\mathrm{ww} / \mathrm{dm}=0.45)$ and narrowly rounded venter. Shell is almost smooth, with very fine biconvex growth lines. Suture line with very high median saddle, acute secondary prongs of the external lobe, rounded ventrolateral saddle, and asymmetric and acute adventive lobe with a convex ventral and a concave dorsal flank.

Description. - The single specimen has a diameter of $36 \mathrm{~mm}$ and is fully chambered. It is discoidal $(\mathrm{ww} / \mathrm{dm}=$ 0.43 ) with a closed umbilicus and broadly rounded venter (Fig. 32). The conch is thickest near the funnel-shaped umbilicus, from which the slightly flattened flanks converge to the venter. The aperture is high, causing a whorl expansion rate of 2.84 .

Poorly preserved smooth shell remains are attached to the specimen. The suture line has the characteristic appearance for Dimorphoceras, with the bifid prongs of the external lobe (Fig. 33C). Secondary subdivision of the external lobe resulted in two almost similar-sized secondary prongs, of which the dorsal one (E1) is slightly deeper and wider than the ventral one (E2). Both secondary lobes are lanceolate and pointed; they are separated by a spatulate subsidiary saddle. The ventrolateral saddle is asymmetric

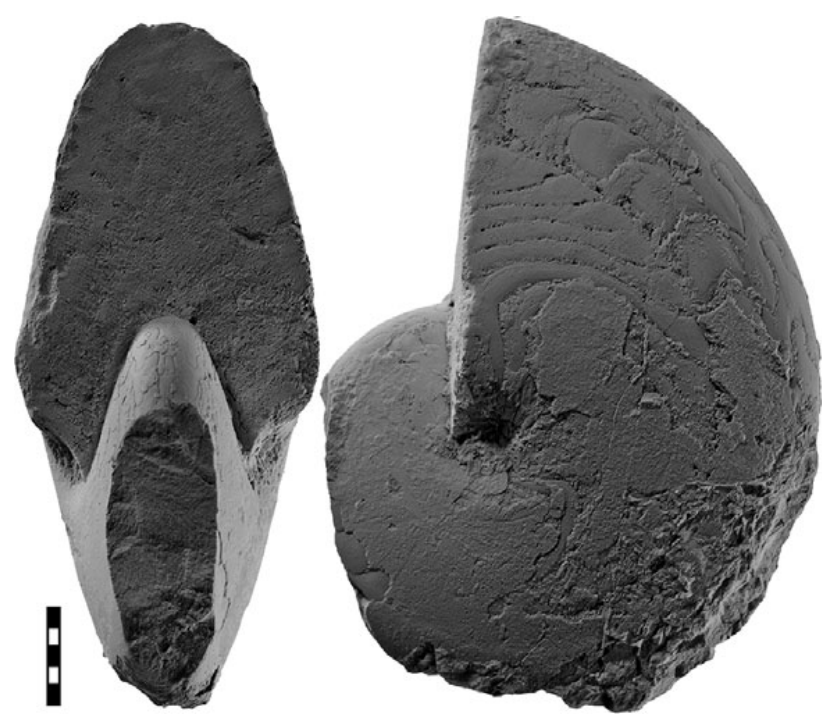

Figure 32. Dimorphoceras worki sp. nov. Holotype UMNH IP 3229 from bed 4 (sample 01UTMI-2) of South Burbank Hills; $\times 2$.
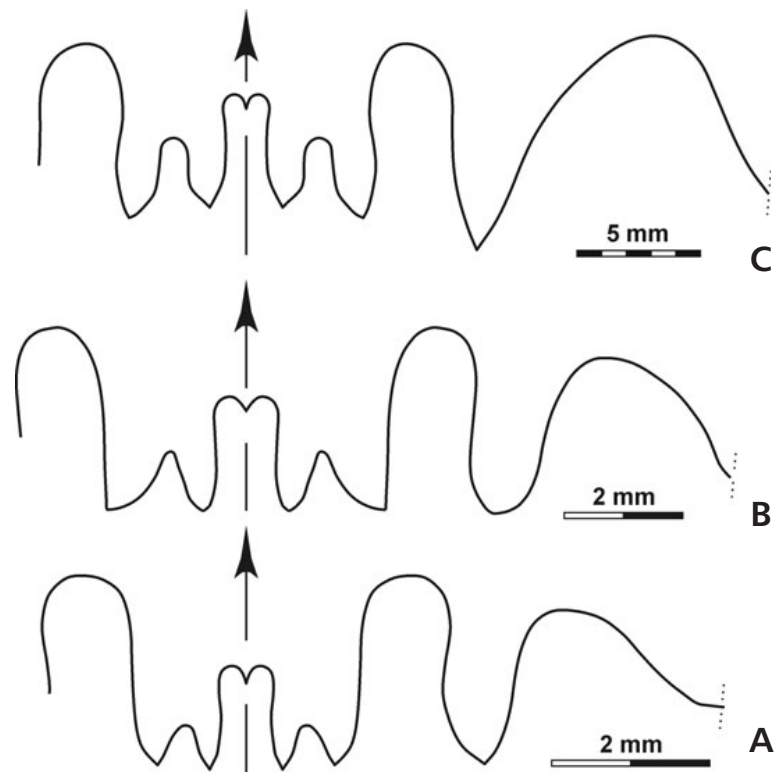

Figure 33. Species of Dimorphoceras. • A - Dimorphoceras rileyi sp. nov, suture line of paratype UMNH IP 3248 from bed 17 (sample 94UTJU-1) of Granite Mountain South, at $10.2 \mathrm{~mm}$ diameter, $5.1 \mathrm{~mm}$ ww, $5.8 \mathrm{~mm}$ wh; $\times 8 . \bullet \mathrm{B}-$ Dimorphoceras rileyi $\mathrm{sp}$. nov, suture line of holotype UMNH IP 3253 from bed 17 (sample 07UTJU-1) of Granite Mountain North, at $12.5 \mathrm{~mm}$ diameter, $6.5 \mathrm{~mm} \mathrm{ww}, 7.5 \mathrm{~mm}$ wh; $\times 6$. - C - Dimorphoceras worki sp. nov, suture line of holotype UMNH IP 3229 from bed 4 (sample 01UTMI-2) of South Burbank Hills, at $34.0 \mathrm{~mm}$ diameter, $14.8 \mathrm{~mm} w w, 19.2 \mathrm{~mm}$ wh; $\times 2.5$.

with a well-rounded top. On the middle of the flank lies the asymmetric cuneiform adventive lobe with a convex ventral and a concave dorsal side.

Discussion. - Dimorphoceras worki is, with an estimated maximum conch diameter of approximately $50 \mathrm{~mm}$, a very 
Table 16. Conch dimensions (in $\mathrm{mm}$ ) and proportions for the holotype of Dimorphoceras worki sp. nov.

\begin{tabular}{lcccccccccccc}
\hline & dm & ww & wh & uw & ah & ww/dm & ww/wh & uw/dm & WER & IZR \\
\hline HT UMNH IP 3229 & 36.3 & 15.6 & 22.0 & 0.0 & 14.8 & 0.43 & 0.71 & 0.00 & 2.84 & 0.33 \\
\hline
\end{tabular}
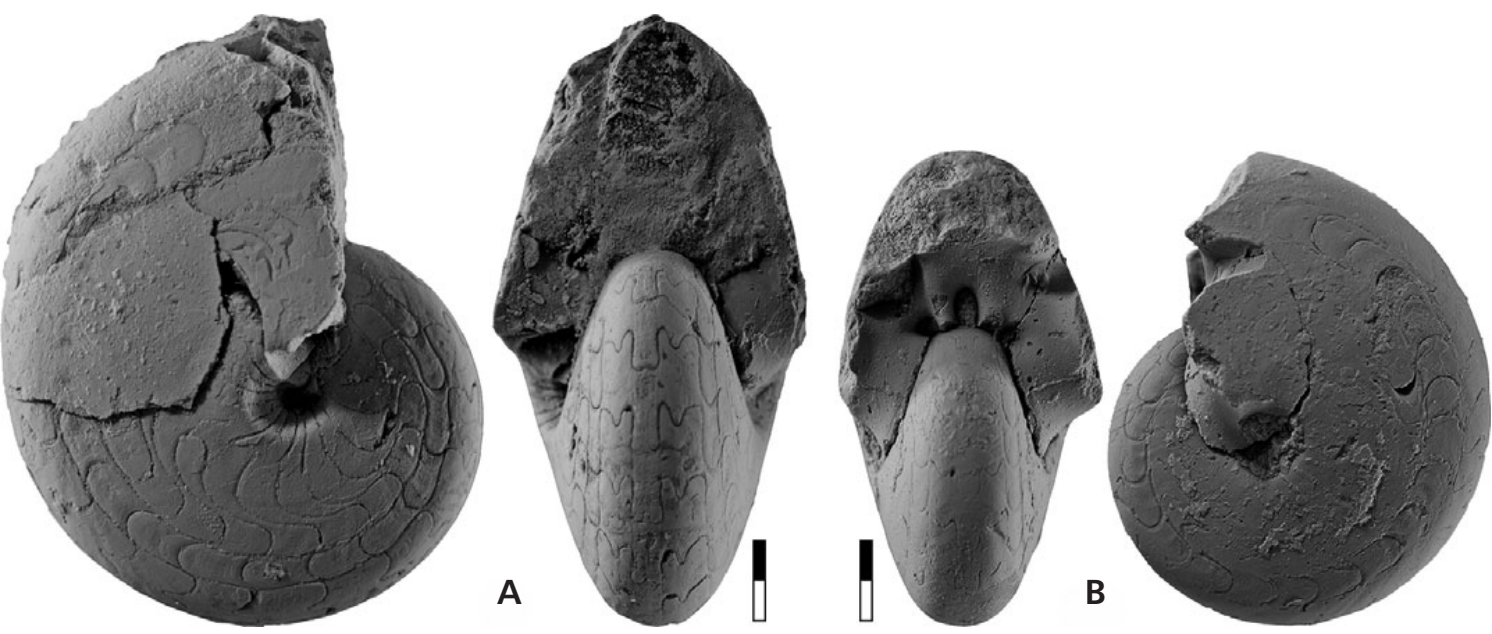

Figure 34. Dimorphoceras rileyi sp. nov. • A - holotype UMNH IP 3253 from bed 17 (sample 07UTJU-1) of Granite Mountain North; $\times 4$. - B - paratype UMNH IP 3246 from bed 17 (sample sample 94UTJU-1) of Granite Mountain South; $\times 4$.

large representative when compared with other species of the entire family Dimorphoceratidae. D. kathleenae (preliminarily named $D$. kathleeni in Moore 1931) is similar but has a slightly narrower conch and a suture line in which the strongly asymmetric E2 lobe is wider than the E1 lobe (the species may belong in the genus Trizonoceras). D. gilbertsoni has a very low saddle that separates the E1 and E2 lobes and is thus clearly separated from $D$. worki. D. rileyi from the Chainman Formation has a blunt adventive lobe which readily distinguishes it.

\section{Dimorphoceras rileyi sp. nov.}

Figures 33A, B, 34

Derivation of name. - After Nicholas J. Riley, to honour his contributions to Carboniferous palaeontology and stratigraphy.

Holotype. - Specimen UMNH IP 3253, illustrated in Fig. 34A.

Type locality and horizon. - Granite Mountain North, bed 17; Camp Canyon Member of Chainman Formation, Calygirtyoceras arcticum Biozone.

Material. - The holotype and 34 paratypes; conch diameter up to $16 \mathrm{~mm}$.

Diagnosis. - Species of Dimorphoceras with a discoidal conch $(\mathrm{ww} / \mathrm{dm}=0.50-0.55)$ and narrowly rounded venter.
Shell is almost smooth, with very fine biconvex growth lines and faint spiral lines. Suture line with high median saddle, acute secondary prongs of the external lobe, rounded ventrolateral saddle, and tongue-shaped, blunt adventive lobe.

Description. - The best-preserved specimen is holotype UMNH IP 3253 with a conch diameter of $15.7 \mathrm{~mm}$ (Fig. 34A). It is entirely septate with twenty chambers and possesses patches of the shell. The conch is thickly lenticular $(\mathrm{ww} / \mathrm{dm}=0.51)$ with an almost closed umbilicus and a high aperture $(\mathrm{WER}=2.50)$. The conch is widest near the funnel-shaped umbilicus, which shows a flattened oblique wall. The shell remains show very fine growth lines with a pronounced ventrolateral saddle and faint, irregularly arranged spiral lines.

Smaller specimens such as paratype UMNH IP 3246 (10.2 mm diameter) are very similar in the conch proportions (ww/dm $=0.52$; WER $=2.52$ ). The umbilical wall is slightly less developed, and the venter is not as narrowly rounded (Fig. 34B).

The suture line of holotype UMNH IP 3253, drawn at $12.5 \mathrm{~mm}$ diameter, shows a median saddle that is higher than half of the external lobe depth; it is encased by asymmetrically subdivided prongs of the external lobe (Fig. 33B). The dorsal of the two new prongs is the more prominent and asymmetric. Both prongs are acute and separated by a subacute saddle. On the flank follow the tongue-shaped, elongate ventrolateral saddle and the adventive lobe, which is also tongue-shaped, slightly asymmetric, and blunt at its base. 
Table 17. Conch dimensions (in $\mathrm{mm}$ ) and proportions for reference specimens of Dimorphoceras rileyi sp. nov.

\begin{tabular}{|c|c|c|c|c|c|c|c|c|c|c|}
\hline & $\mathrm{dm}$ & ww & wh & uw & ah & ww/dm & ww/wh & uw/dm & WER & IZR \\
\hline HT UMNH IP 3253 & 15.7 & 8.1 & 9.1 & 0.3 & 5.8 & 0.51 & 0.89 & 0.02 & 2.50 & 0.36 \\
\hline PT MB.C.12007.1 & 11.5 & 5.5 & 6.4 & 0.0 & 3.9 & 0.48 & 0.86 & 0.00 & 2.28 & 0.39 \\
\hline PT UMNH IP 3246 & 10.2 & 5.3 & 6.0 & 0.2 & 3.8 & 0.52 & 0.89 & 0.02 & 2.52 & 0.37 \\
\hline HT UMNH IP 3237 & 10.0 & 4.9 & 5.8 & 0.1 & 3.6 & 0.49 & 0.85 & 0.00 & 2.41 & 0.38 \\
\hline
\end{tabular}

Paratype UMNH IP 3248 shows, at 10.2 mm diameter, a very similar suture line that differs from the larger specimen in the lower median saddle and the rounded saddle between the secondary prongs of the external lobe (Fig. 33A).

Discussion. - Dimorphoceras rileyi differs from $D$. worki and D. kathleenae in the blunt adventive lobe and the V-shaped secondary prongs of the external lobe. D. gilbertsoni has a strongly asymmetric adventive lobe, in contrast to the tongue-shaped lobe in $D$. rileyi. The stratigraphically much older, late Chadian D. leagramense has a very similar suture line, but differs in the much more lenticular conch at comparable diameters $(\mathrm{ww} / \mathrm{dm}=0.25-0.30)$ at $10-12 \mathrm{~mm}$ diameter in contrast to $0.50-0.55$ in $D$. rileyi. D. algens from the Kuna Formation of Alaska possesses rounded external and adventive lobes.

Subfamily Glyphiolobinae Ruzhencev \& Bogoslovskaya, 1969

Subfamily definition. - Dimorphoceratidae with a subdivided adventive lobe.

Included genera. - Glyphiolobus Gordon, 1965; Metadimorphoceras Moore, 1958; Paradimorphoceras Ruzhencev, 1947; Sulcodimorphoceras Manger \& Pareyn, 1979; Anthracoceratites Ramsbottom, 1970; Currieoceras Manger, 1988 [synonym of Glyphiolobus Gordon, 1965].

\section{Genus Metadimorphoceras Moore, 1958}

Type species. - Goniatites splendidus Brown, 1841 (original designation).

Genus definition. - Glyphiolobinae with a subdivision of the external lobe into more than two tertiary lobes.

Included species. - aguinosum: Metadimorphoceras aguinosum Korn \& Ebbighausen, 2008, p. 94; Moroccan Meseta; complex: Dimorphoceras complex Moore, 1939, p. 116; Yorkshire; denticulatum: Dimorphoceras denticulatum Schmidt, 1925, p. 601; Rhenish Mountains; dislobatum: Metadimorphoceras dislobatum Yang, 1986, p. 265;
Ningxia; gorbovense: Paradimorphoceras gorbovense Kusina \& Yatskov, 1988, p. 33; Novaya Zemlya; heterodivisum: Paradimorphoceras heterodivisum Ruan, 1981, p. 208; Guangxi; hodsoni: Dimorphoceras (Metadimorphoceras) hodsoni Moore, 1958, p. 223; Ireland; inflatum: Dimorphoceras inflatum Moore, 1939, p. 116; Lancashire; lenticulare: Metadimorphoceras lenticulare Yang, 1986, p. 264; Ningxia; mangeri: Metadimorphoceras mangeri sp. nov.; Antler Foreland Basin; moorei: Dimorphoceras moorei Hodson, 1954, p. 362; Ireland; orientale: Paradimorphoceras orientale Ruzhencev \& Bogoslovskaya, 1971, p. 195; South Urals; pix: Metadimorphoceras pix Korn, 1997, p. 46; South Portugal; pseudodiscrepans: Dimorphoceras pseudodiscrepans Moore, 1939, p. 112; Lancashire; ribblense: Dimorphoceras ribblense Moore, 1936, p. 190; Lancashire; richardsi: Metadimorphoceras richardsi sp. nov.; Antler Foreland Basin; saharicum: Dimorphoceras looneyi var. saharica Dollé, 1912, p. 250; Western Algeria; saleswheelense: Dimorphoceras saleswheelense Moore, 1939, p. 118; Lancashire; saundersi: Metadimorphoceras saundersi Manger \& Quinn, 1972, p. 311; Arkansas; splendidum: Goniatites splendidus Brown, 1841, p. 215; Yorkshire; strictum: Paradimorphoceras strictum Ruzhencev \& Bogoslovskaya, 1971, p. 196; South Urals; subdivisum: Metadimorphoceras subdivisum Manger \& Quinn, 1972, p. 312; Arkansas; tongxinense: Paradimorphoceras tongxinense Gao, 1983, p. 464; Ningxia; varians: Dimorphoceras varians Moore, 1939, p. 113; Lancashire; wiswellense: Dimorphoceras wiswellense Moore, 1939, p. 115; Lancashire.

Discussion. - Metadimorphoceras has an almost global distribution and 23 valid species are listed in the AMMON database (Korn \& Ilg 2010); these derive from a wide stratigraphic interval ranging from the middle Late Viséan Goniatites crenistria interval to the Kinderscoutian $\mathrm{R}_{1}$ Zone in Europe (Moore 1939) and even in the Yeadonian $\mathrm{G}_{1}$ Zone in Arkansas (Manger 1988). Separation of species is almost completely based on suture line characters. The European and North African species have been separated by Korn \& Ebbighausen (2008) into three groups, based on the subdivision of the adventive lobe. According to this scheme, both species from the Camp Canyon Member belong in the first group, which is characterized by a simple subdivision of the adventive lobe into two similarly sized prongs. 

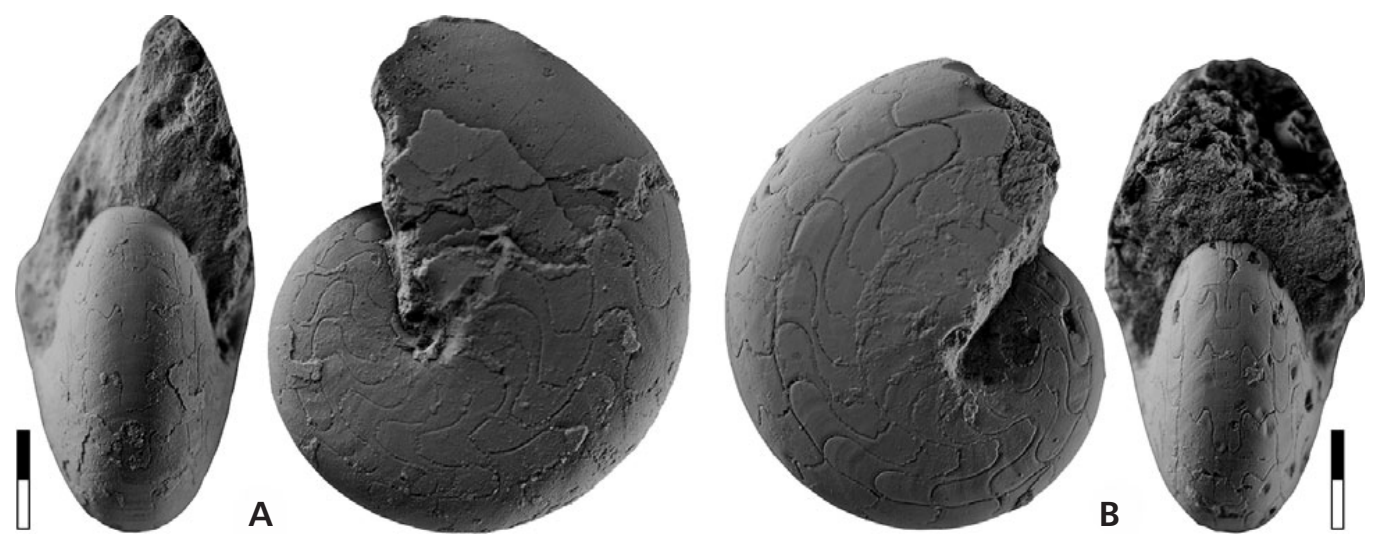

Figure 35. Metadimorphoceras mangeri sp. nov. • A - holotype UMNH IP 3273 from bed 6 (sample 01UTMI-3) of South Burbank Hills; $\times 5$. - B - paratype UMNH IP 3281 from bed 4 (sample 01UTMI-2) of South Burbank Hills; $\times 5$.

Table 18. Conch dimensions (in $\mathrm{mm}$ ) and proportions for reference specimens of Metadimorphoceras mangeri sp. nov.

\begin{tabular}{|c|c|c|c|c|c|c|c|c|c|c|}
\hline & $\mathrm{dm}$ & ww & wh & uw & $\mathrm{ah}$ & ww/dm & ww/wh & uw/dm & WER & IZR \\
\hline PT UMNH IP 3279 & 13.5 & 6.2 & 8.0 & 0.0 & 4.8 & 0.46 & 0.77 & 0.00 & 2.43 & 0.40 \\
\hline HT UMNH IP 3273 & 8.6 & 4.6 & 4.9 & 0.0 & 3.2 & 0.54 & 0.94 & 0.00 & 2.49 & 0.36 \\
\hline PT UMNH IP 3278 & 5.4 & 3.7 & 2.9 & 0.0 & - & 0.69 & 1.28 & 0.00 & - & - \\
\hline
\end{tabular}

Metadimorphoceras mangeri sp. nov.

Figures 35, 36D

Derivation of name. - After Walter M. Manger, to honour his contributions to Carboniferous ammonoid palaeontology and particularly the dimorphoceratids.

Holotype. - Specimen UMNH IP 3273, illustrated in Fig. 35A.

Type locality and horizon. - South Burbank Hills, bed 6; Camp Canyon Member of Chainman Formation, Girtyoceras primum Biozone.

Material. - The holotype and ten paratypes; conch diameter up to $13 \mathrm{~mm}$.

Diagnosis. - Species of Metadimorphoceras with a discoidal conch $(\mathrm{ww} / \mathrm{dm}=0.45-0.55)$ and narrowly rounded venter. Shell is almost smooth, with very fine biconvex growth lines. Suture line with very high median saddle, subacute secondary prongs of the external lobe, rounded ventrolateral saddle, and asymmetric bifid adventive lobe with a low saddle between the secondary, subacute prongs.

Description. - Holotype UMNH IP 3273 is the bestpreserved specimen of the material. It has a diameter of $8.6 \mathrm{~mm}$ and is discoidal ( $\mathrm{ww} / \mathrm{dm}=0.54)$ with a closed umbilicus and a high aperture (WER $=2.50)$. The conch is, as characteristic for dimorphoceratids, thickest at the umbili- cus, the flanks converge markedly, and the venter is narrowly rounded. Shell remains show a smooth surface, and the internal mould possesses weak impressions of biconvex growth lines (Fig. 35A).

The suture line of paratype UMNH IP $3280(5.2 \mathrm{~mm}$ Ww) shows the narrow, parallel-sided median saddle and the subdivided external lobe (Fig. 36D). The sides of the external lobe possess two asymmetric prongs, both showing incipient further subdivision, with the dorsal prong being wider than the ventral one. The adventive lobe is subdivided, but the saddle between the two secondary lobes is very low.

Discussion. - Metadimorphoceras mangeri has one of the simplest suture line of the genus. The adventive lobe has just reached the stage of secondary subdivision, and the external lobe is still rather simple. This combination suggests a phylogenetic position near the base of the Metadimorphoceras evolutionary branch (Manger, 1988). The incomplete subdivision of the adventive lobe is a criterion that separates $M$. mangeri from all other species of the genus.

\section{Metadimorphoceras richardsi sp. nov.}

Figures 36A-C, 37

Derivation of name. - After Barry Richards, who helped to collect the material.

Holotype. - Specimen UMNH IP 3290, illustrated in Fig. 37B. 
Type locality and horizon. - Hamilton Canyon, bed 44; Camp Canyon Member of Chainman Formation, Goniatites eganensis Biozone.

Material. - The holotype and eight paratypes; conch diameter up to $15 \mathrm{~mm}$.

Diagnosis. - Species of Metadimorphoceras with a discoidal conch $(\mathrm{ww} / \mathrm{dm}=0.50-0.55)$ and narrowly rounded venter. Shell almost smooth, with very fine biconvex growth lines. Suture line with very high median saddle, acute secondary prongs of the external lobe with incipient further subdivision, rounded ventrolateral saddle, and asymmetric bifid adventive lobe with acute prongs.

Description. - The two well-preserved specimens UMNH IP 3292 and UMNH IP 3290 show, at 13-14.5 mm conch diameter, very similar proportions, with a ww/dm ratio of little more than 0.50, a closed umbilicus, and a high aperture (WER nearly 2.60). The conch shape is thus characteristic for the genus (Fig. 37).

The smaller specimens UMNH IP 3294 (9.7 mm diameter), MB.C.12010.2 (8.7 mm diameter), and MB.C.12010.1 (8 mm diameter) are thickly lenticular conchs $(\mathrm{ww} / \mathrm{dm}=$ $0.52-0.55)$ with a high aperture (WER $=2.55-2.60)$. As characteristic for dimorphoceratids, the conch is thickest near the almost closed, funnel-shaped umbilicus. The three specimens are smooth internal moulds of the phragmocone; they show barely visible rhythmic folds of strengthened growth lines.

Shell ornament is preserved in some of the specimens. Specimen UMNH IP 3290 appears to be completely smooth, but the internal mould shows faint traces of impressed biconvex growth lines (Fig. 37B). Specimen MB.C.12010.3 shows a three-dimensionally preserved phragmocone of $9.3 \mathrm{~mm}$ diameter and the impression of the somewhat crushed body chamber. The steinkern of the phragmocone is almost smooth, but remains of the shell show delicate spiral lines. These spirals are best visible on the impressed body chamber, where they are more prominent than the biconvex, periodically strengthened growth lines.

The suture line is best visible in paratype UMNH IP 3293 (9.4 mm wh) and holotype UMNH IP 3290 (4.8 mm ww). Both show a typical tongue-shaped median saddle, bordered by the subdivided sides of the external lobe, in which the dorsal prong is a little bit wider than the ventral prong
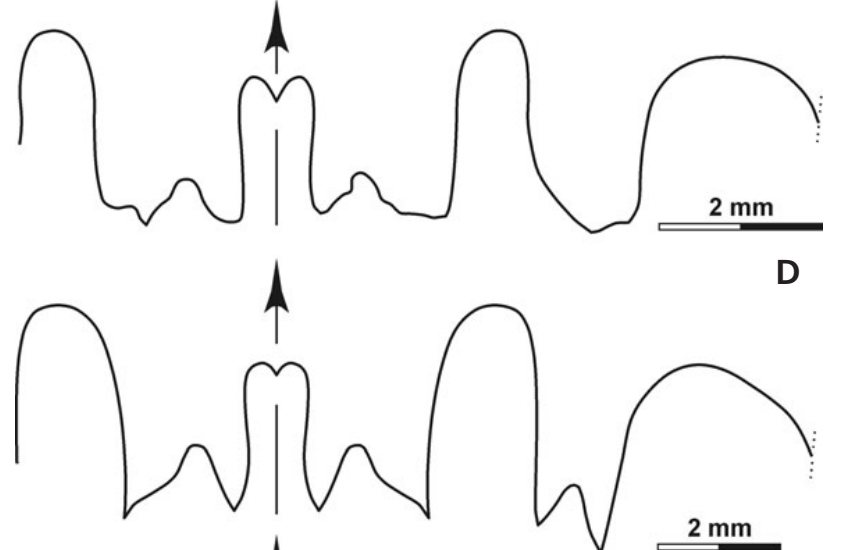

D

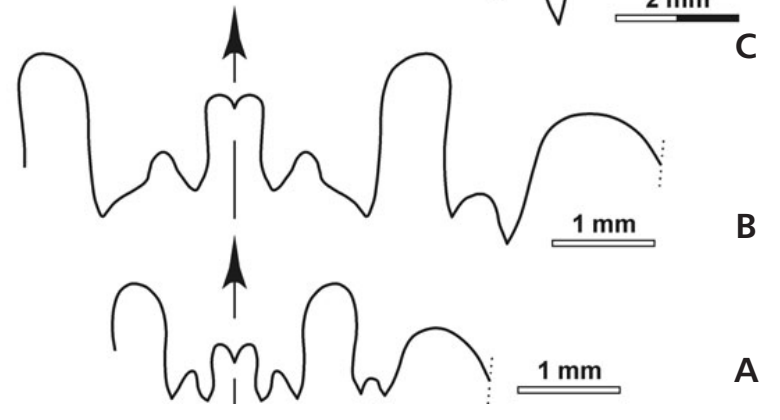

Figure 36. Species of Metadimorphoceras. - A - Metadimorphoceras richardsi sp. nov, suture line of paratype MB.C.12010.1 from bed 25 of South Burbank Hills, at $3.6 \mathrm{~mm}$ ww; $\times 10$. $・ \mathrm{~B}-$ Metadimorphoceras richardsi sp. nov, suture line of holotype UMNH IP 3290 from bed 44 (sample 07NVWP-3) of Hamilton Canyon, at $4.8 \mathrm{~mm} \mathrm{ww} \times 10$. - C -Metadimorphoceras richardsi sp. nov, suture line of paratype UMNH IP 3293 from bed 44 (sample 95NVWP-15) of Hamilton Canyon, at $9.4 \mathrm{~mm}$ wh; $\times 6 . \bullet \mathrm{D}-$ Metadimorphoceras mangeri $\mathrm{sp}$. nov, suture line of paratype UMNH IP 3280 from bed 4 (sample 01UTMI-2) of South Burbank Hills, at $5.2 \mathrm{~mm} w w ; \times 8$.

(Fig. 36B, C). The asymmetry implies an incipient further subdivision of the dorsal prong. Both prongs are acute. The ventrolateral saddle is narrow and high, and on the flank follows the bifid adventive lobe, in which the outer prong is less deep as the inner one.

Smaller specimens such as paratype MB.C.12010.1 (drawn at $3.6 \mathrm{~mm} \mathrm{ww}$ ) possess a moderately high median saddle (reaching half of the external lobe depth). It is encased by the almost symmetric secondary prongs of the external lobe, which are subdivided into two almost symmetric, acute tertiary prongs. On the flank follow an almost symmetric, slightly inflated ventrolateral saddle and a bifid

Table 19. Conch dimensions (in $\mathrm{mm}$ ) and proportions for reference specimens of Metadimorphoceras richardsi sp. nov.

\begin{tabular}{|c|c|c|c|c|c|c|c|c|c|c|}
\hline & $\mathrm{dm}$ & ww & wh & uw & $\mathrm{ah}$ & ww/dm & ww/wh & uw/dm & WER & IZR \\
\hline PT UMNH IP 3292 & 14.7 & 7.1 & 9.1 & 0.2 & 5.5 & 0.49 & 0.79 & 0.01 & 2.56 & 0.39 \\
\hline HT UMNH IP 3290 & 13.2 & 6.8 & 8.3 & 0.2 & 5.0 & 0.52 & 0.82 & 0.02 & 2.58 & 0.40 \\
\hline HT UMNH IP 3294 & 9.7 & 5.3 & 5.5 & 0.1 & 3.6 & 0.55 & 0.96 & 0.01 & 2.55 & 0.34 \\
\hline PT MB.C.12010.2 & 8.7 & 4.7 & 5.3 & 0.1 & 3.3 & 0.54 & 0.89 & 0.01 & 2.60 & 0.38 \\
\hline PT MB.C.12010.1 & 8.0 & 4.2 & 4.5 & 0.2 & - & 0.52 & 0.93 & 0.02 & - & - \\
\hline
\end{tabular}



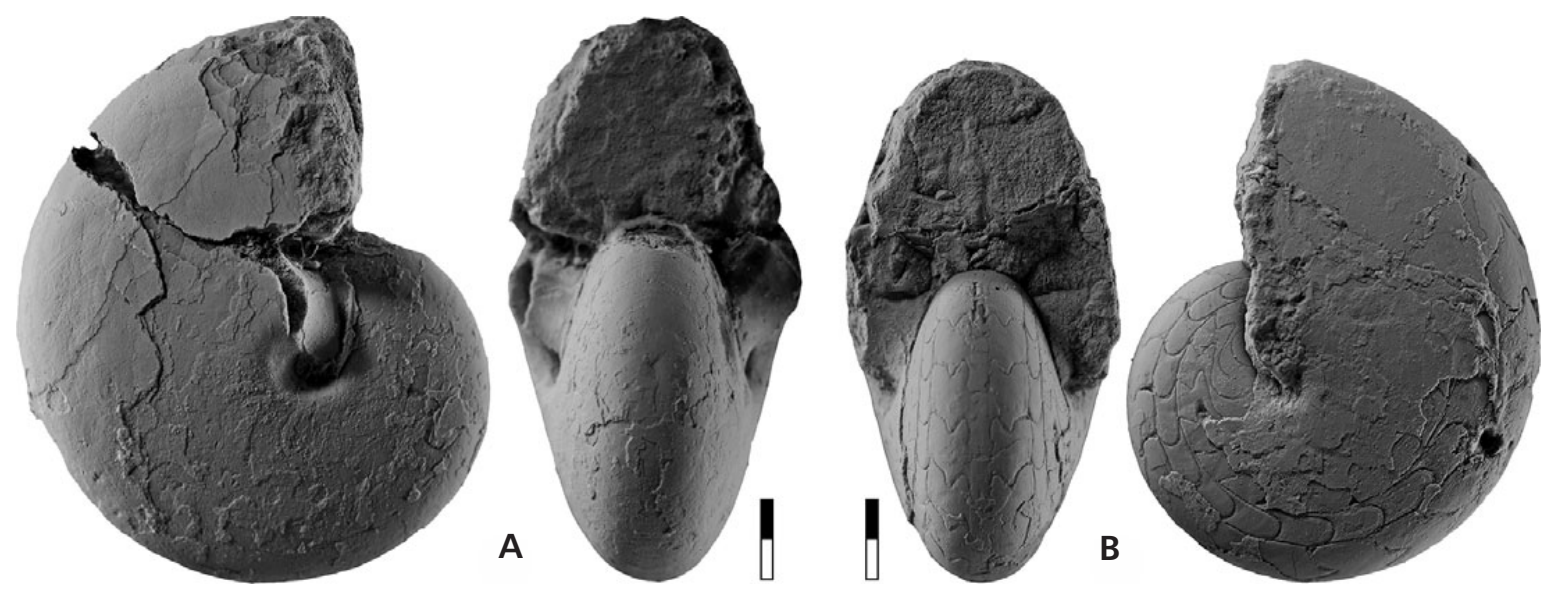

Figure 37. Metadimorphoceras richardsi sp. nov. • A - paratype UMNH IP 3292 from bed 25 (sample 07UTMI-1) of South Burbank Hills; $\times 5$. - B - holotype UMNH IP 3290 from bed 44 (sample 07NVWP-3) of Hamilton Canyon; $\times 5$.

adventive lobe with two acute prongs of the same size (Fig. 36A).

Discussion. - Metadimorphoceras richardsi belongs to the simple-sutured species of the genus (Manger 1988), showing a degree of complexity comparable to the late Asbian (British $\mathrm{P}_{1}$ a Zone) M. pseudodiscrepans (Moore, 1939), which, however, already shows a further subdivision of the external lobe. A similar complexity stage, but also with a weak tertiary subdivision of the external lobe, is visible in the early Brigantian M. hodsoni Moore, 1958. This shows that $M$. richardsi obviously represents a very early stage in the diversification of the genus Metadimorphoceras.

Family Berkhoceratidae Librovitch, 1957

Family definition. - Dimorphocerataceae with a low, converging median saddle and a strongly converging ventrolateral saddle.

Included genera. - Kazakhoceras Ruzhencev, 1947; Berkhoceras Librovitch, 1957 [synonym of Kazakhoceras Ruzhencev, 1947].

\section{Genus Kazakhoceras Ruzhencev, 1947}

Type species. - Kazakhoceras yanshini Ruzhencev, 1947 (original designation).

Genus definition. - As for the family.

Included species. - armstrongi: Neodimorphoceras armstrongi Currie, 1954, p. 593; Dunbartonshire; boreale: Berkhoceras boreale Librovitch, 1957, p. 260; Novaya Zemlya [synonym of $K$. yanshini]; bylundi: Kazakhoceras bylundi sp. nov.; Antler Foreland Basin; compressum: Kazakhoceras compressum Liang \& Gao, 1963, p. 565; Guangxi [synonym of K. yanshini]; hawkinsi: Neodimorphoceras hawkinsi Moore, 1930, p. 168; Lancashire; lenticulum: Kazakhoceras lenticulum Ruan, 1981, p. 212; Guangxi; scaliger: Dimorphoceras ?scaliger Schmidt, 1934, p. 458; Rhenish Mountains; yanshini: Kazakhoceras yanshini Ruzhencev, 1947, p. 522; South Urals.

Discussion. - Kazakhoceras was so far only recorded from stratigraphically much younger horizons. The genus is rather frequent in beds around the Viséan-Serpukhovian boundary of the South Urals (Ruzhencev \& Bogoslovskaya 1971), but has also rarely been recorded from late Brigantian beds of North England (Moore 1930) and the Rhenish Mountains (Korn 1988). With the new finds, the range of Kazakhoceras is pulled down markedly into the Asbian.

\section{Kazakhoceras bylundi sp. nov.}

Figures 38, 39

Derivation of name. - After Kevin Bylund who helped to collect the material.

Holotype. - Specimen UMNH IP 3309, illustrated in Fig. 38A.

Type locality and horizon. - Middle Confusion Range 1, bed 10; Camp Canyon Member of Chainman Formation, Calygirtyoceras arcticum Biozone.

Material. - The holotype and eight paratypes; conch diameter up to $45 \mathrm{~mm}$.

Diagnosis. - Species of Kazakhoceras with a thinly discoidal conch $(\mathrm{ww} / \mathrm{dm}=0.35)$ and a very narrowly rounded 

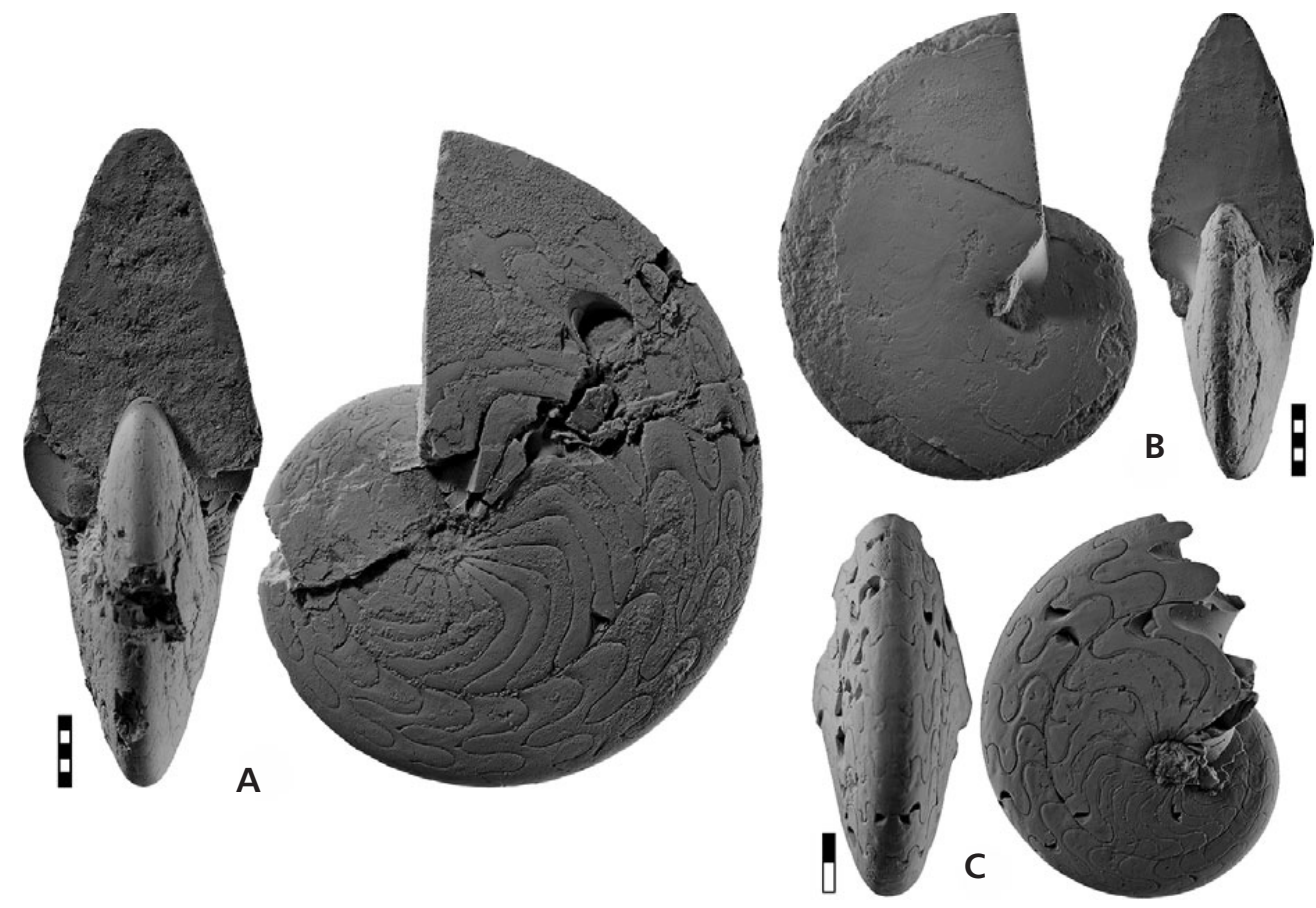

Figure 38. Kazakhoceras bylundi sp. nov. • A - holotype UMNH IP 3309 from bed 10 (sample 05UTMI-3) of South Confusion Range $1 ; \times 1.5$. - B - paratype UMNH IP 3308 from bed 9 (sample 97UTMI-13) of Jensen Wash; $\times 1.5$. $・$ C - paratype UMNH IP 3311 from bed 17 (sample sample 94UTJU-1) of Granite Mountain South; × 3.

venter. Shell almost smooth, with very fine biconvex growth lines. Suture line with rounded ventrolateral saddles.

Description. - Paratypes UMNH IP 3310 and UMNH IP 3306 were sectioned for the study of the conch ontogeny (Fig. 39A, B). It shows a globular conch early in ontogeny, followed by a growth stage in which the whorls become laterally compressed and the conch more slender. The umbilicus is slightly opened in this early stage up to $3 \mathrm{~mm}$ conch diameter, but closes rapidly. At $6 \mathrm{~mm}$ diameter, the conch is already discoidal $(\mathrm{ww} / \mathrm{dm}=0.50)$ with a high aperture $($ WER $=2.40$ ) and a narrowly rounded venter. The umbilical margin is rounded in this whorl. Already on half of a volution later, at $10.5 \mathrm{~mm}$ diameter, the umbilical margin has become flattened and gives the umbilicus a funnel-like shape. Acceleration of aperture heightening is continuing at this stage, the whorl expansion rate amounts 2.88 here (Fig. 39E-G). At the same time, the flanks become slightly flattened and converge towards the continuously narrowing venter. Another half of a volution later (17 $\mathrm{mm}$ diameter), the whorl cross section is very similar, but the relative height of the aperture decreases $($ WER $=2.74)$.

The well-preserved specimens allow the study of growth stages between approximately 20 and $44 \mathrm{~mm}$. The largest of them, holotype UMNH IP 3309, has $44 \mathrm{~mm}$ conch diameter and is fully chambered
(Fig. 38A). It is a lentil-shaped specimen $(\mathrm{ww} / \mathrm{dm}=$ 0.35 ) with very few attached shell remains. The conch is thickest near the closed umbilicus, the flanks are almost flat and converge towards the very narrowly rounded venter. The aperture is very high, resulting in a whorl expansion rate of 2.58 .

The smaller paratype UMNH IP 3308 has $31 \mathrm{~mm}$ conch diameter and is similar to the larger specimen, but the aperture is even higher (WER $=2.83$ ). Shell remains are preserved in this specimen; they show very fine, strongly biconvex growth lines with equally high dorsolateral and ventrolateral projections and a very deep ventral sinus (Fig. 38B).

Suture lines were drawn from paratype UMNH IP 3311 (Fig. 39C) at $13 \mathrm{~mm}$ and from holotype UMNH IP 3309 (Fig. 39D) at $32 \mathrm{~mm}$ diameter. The adult suture line is typical for the genus with a secondarily subdivided external lobe. The primary prong of the external lobe is lanceolate and deeper than the secondary prong; both are separated by a narrow tongue-shaped saddle. The ventrolateral saddle is almost symmetric, at least in its upper part, and has a semicircular top. On the flank follows the asymmetric adventive lobe with a convex ventral and a concave dorsal flank.

Discussion. - Kazakhoceras bylundi has a similar conch like $K$. hawkinsi and K. yanshini, but differs in ornament and suture details. K. hawkinsi and K. yanshini have an 

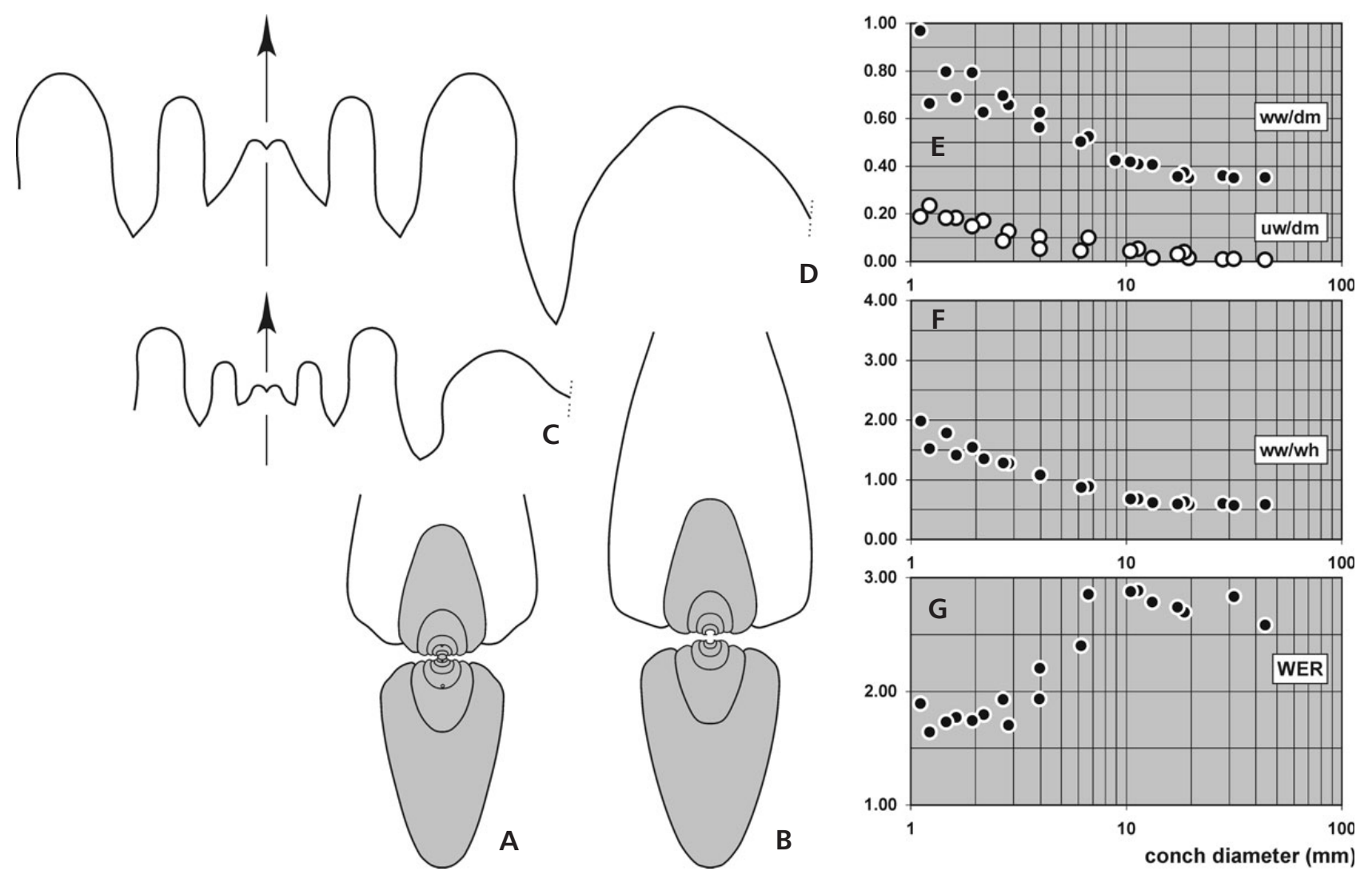

Figure 39. Kazakhoceras bylundi sp. nov. • A - cross section of paratype UMNH IP 3310 from bed 10 (sample 05UTMI-3) of South Confusion Range $1 ; \times 2.5$. $\bullet$ B - cross section of paratype UMNH IP 3306 from bed 17 (sample 07UTJU-1) of Granite Mountain South; $\times 2.5$. $\bullet$ C suture line of paratype UMNH IP 3311 from bed 17 (sample sample 94UTJU-1) of Granite Mountain South, at $13.2 \mathrm{~mm}$ diameter, $5.4 \mathrm{~mm}$ ww, $8.7 \mathrm{~mm}$ wh; $\times 5.0$. $・$ D - suture line of holotype UMNH IP 3309 from bed 10 (sample 05UTMI-3) of South Confusion Range 1, at $31.1 \mathrm{~mm}$ diameter, $11.1 \mathrm{~mm}$ ww, $19.1 \mathrm{~mm}$ wh; $\times 5.0$. - E-G - ontogenetic development of the conch width index (ww/dm), umbilical width index (uw/dm), whorl width index (ww/wh), and whorl expansion rate (WER) of all available specimens.

ornament with spiral lines in contrast to $K$. bylundi, where only very fine growth lines are present. The suture line, which is very similar in the three species, offers further criteria for a separation: K. hawkinsi and K. yanshini have a subacute ventrolateral saddle, particularly regarding the first, whereas in $K$. bylundi the ventrolateral saddles are rounded.

\section{Superfamily Goniatitaceae de Haan, 1825}

Included families. - Goniatitidae de Haan, 1825; Agathiceratidae von Arthaber, 1911; Delepinoceratidae Ruzhencev, 1957; Glyphioceratidae Hyatt, 1884 [synonym of Goniatitidae de Haan, 1825].

\section{Family Goniatitidae de Haan, 1825}

Included subfamilies. - Goniatitinae de Haan, 1825; Arnsbergitinae Korn \& Ebbighausen, 2008; Sygambritinae Korn, 1988; Progoniatitinae Korn, Bockwinkel \& Ebbig- hausen, 2010; Habadraitinae Korn, Bockwinkel \& Ebbighausen, 2010; Antegoniatitinae Korn, Bockwinkel \& Ebbighausen, 2010.

\section{Subfamily Goniatitinae de Haan, 1825}

Included genera. - Goniatites de Haan, 1825; Hypergoniatites Ruzhencev \& Bogoslovskaya, 1970; Goniatitella Korn, 1988; Glyphioceras Hyatt, 1884 [synonym of Goniatites de Haan, 1825]; Sphenoceras Foord, 1903 [synonym of Goniatites de Haan, 1825].

\section{Genus Goniatites de Haan, 1825}

Type species. - Conchiliolithus Nautilites (sphaericus) Martin, 1809 [nomen nudum], = Ammonites sphaericus Sowerby, 1814 (Opinion 420 ICZN, 1956).

Genus definition. - Goniatitinae with subinvolute inner whorls; the umbilicus becomes closed in early ontogeny. 
Table 20. Conch ontogeny (Fig. 39) of Kazakhoceras bylundi sp. nov.

\begin{tabular}{|c|c|c|c|}
\hline $\mathrm{dm}$ & conch shape & whorl cross section shape & aperture \\
\hline $2 \mathrm{~mm}$ & $\begin{array}{l}\text { thickly pachyconic; involute } \\
\text { (ww/dm } \sim 0.75 ; \text { uw/dm } \sim 0.16 \text { ) }\end{array}$ & weakly depressed; strongly embracing (ww/wh 1.35; IZR 0.45) & moderate $($ WER 1.80) \\
\hline $10 \mathrm{~mm}$ & $\begin{array}{l}\text { thinly discoidal; involute } \\
\text { (ww/dm } \sim 0.42 ; \text { uw/dm } \sim 0.05 \text { ) }\end{array}$ & weakly compressed; strongly embracing (ww/wh 0.70; IZR 0.30) & very high $($ WER 2.90) \\
\hline $20 \mathrm{~mm}$ & $\begin{array}{l}\text { thinly discoidal; involute } \\
\text { (ww/dm } \sim 0.37 ; \text { uw/dm } \sim 0.03 \text { ) }\end{array}$ & weakly compressed; strongly embracing $(\mathrm{ww} / \mathrm{wh} \sim 0.60 ; \mathrm{IZR} \sim 0.35$ ) & very high $($ WER 2.70) \\
\hline $45 \mathrm{~mm}$ & $\begin{array}{l}\text { thinly discoidal; involute } \\
\text { (ww/dm } \sim 0.35 ; \text { uw/dm } \sim 0.00 \text { ) }\end{array}$ & weakly compressed; strongly embracing $(\mathrm{ww} / \mathrm{wh} \sim 0.60 ; \mathrm{IZR} \sim 0.35$ ) & very high $($ WER 2.60) \\
\hline
\end{tabular}

Table 21. Conch dimensions (in $\mathrm{mm}$ ) and proportions for reference specimens of Kazakhoceras bylundi sp. nov.

\begin{tabular}{|c|c|c|c|c|c|c|c|c|c|c|}
\hline & $\mathrm{dm}$ & ww & wh & uw & ah & $\mathrm{ww} / \mathrm{dm}$ & ww/wh & $\mathrm{uw} / \mathrm{dm}$ & WER & IZR \\
\hline HT UMNH IP 3309 & 44.1 & 15.6 & 26.4 & 0.3 & 16.7 & 0.35 & 0.59 & 0.01 & 2.58 & 0.37 \\
\hline PT UMNH IP 3308 & 31.5 & 11.1 & 19.4 & 0.4 & 12.8 & 0.35 & 0.57 & 0.01 & 2.83 & 0.34 \\
\hline PT UMNH IP 3306 & 18.6 & 7.0 & 11.1 & 0.8 & 7.3 & 0.37 & 0.63 & 0.04 & 2.70 & 0.34 \\
\hline PT UMNH IP 3310 & 17.3 & 6.2 & 10.4 & 0.5 & 6.9 & 0.36 & 0.60 & 0.03 & 2.74 & 0.34 \\
\hline PT UMNH IP 3311 & 13.2 & 5.4 & 8.7 & 0.2 & 5.3 & 0.41 & 0.62 & 0.02 & 2.79 & 0.39 \\
\hline
\end{tabular}

External lobe V-shaped, very narrow or narrow, usually with slightly curved flanks.

Included species. - americanus: Goniatites americanus Gordon, 1971, p. C41; Utah; antiquatus: Goniatites antiquatus Bisat, 1934, p. 302; Yorkshire; asturicus: Glyphioceras sphaericum var. asturica Frech, 1902, p. 84; Cantabrian Mountains; constractus: Goniatites constractus Liang \& Wang, 1991, p. 93; Xinjiang; crenifalcatus: Goniatites crenifalcatus crenifalcatus Bogoslovskaya, 1966, p. 40; South Urals; crenistria: Goniatites crenistria Phillips, 1836, p. 234; Yorkshire; deceptus: Goniatites deceptus sp. nov.; Antler Foreland Basin, Nevada-Utah; dinckleyensis: Goniatites crenistria dinckleyense Bisat, 1928, p. 132; Lancashire [synonym of G. fimbriatus]; eganensis: Goniatites eganensis sp. nov.; Antler Foreland Basin, Nevada-Utah; evelinae: Goniatites evelinae Korn \& Ebbighausen, 2006, p. 29; Anti-Atlas; fimbriatus: Glyphioceras fimbriatus Foord \& Crick, 1897, p. 303; Yorkshire or Lancashire; fuhrmanni: Goniatites fuhrmanni Schindewolf, 1951, p. 71; Harz; gerberi: Goniatites gerberi Korn \& Ebbighausen, 2006, p. 27; Anti-Atlas; globiformis: Goniatites (Goniatites) stenumbilicatus globiformis Kullmann, 1961, p. 294; Cantabrian Mountains; globoides: Glyphioceras crenistria var. globoides Schmidt, 1925, p. 566; Rhenish Mountains [synonym of G. crenistria]; grandis: Goniatites grandis Liang \& Wang, 1991, p. 95; Xinjiang; hudsoni: Goniatites hudsoni Bisat, 1934, p. 303; Lancashire; intermedius: Glyphioceras intermedium Kobold, 1933, p. 487; Harz [homonym of Goniatites intermedius Münster, 1832; synonym of G. fimbriatus]; interruptus: Ammonites interruptus de Koninck, 1844, p. 580; Belgium; involutus: Goniatites involutus de Koninck,
1880, p. 110; Belgium; lazarus: Goniatites lazarus Korn, Klug \& Mapes, 2005, p. 359; Anti-Atlas; lepidus: Goniatites lepidus Brandon \& Hodson, 1984, p. 21; Ireland [nomen nudum]; maximus: Goniatites maximus Bisat, 1934, p. 298; Yorkshire [homonym of Goniatites maximus Münster, 1832; synonym of G. moorei]; moorei: Goniatites moorei Weyer, 1972, p. 180; Yorkshire; multiliratus: Goniatites multiliratus Gordon, 1962, p. 356; Oklahoma; olsysya: Goniatites olsysya Korn, 2001, p. 228; North Urals; praestriatus: Glyphioceras crenistria var. praestriata Schmidt, 1925, p. 566; Rhenish Mountains [synonym of G. spirifer]; pseudosphaericus: Goniatites pseudosphaericus Brandon \& Hodson, 1984, p. 21; Ireland [nomen nudum]; rodioni: Goniatites rodioni Korn \& Ebbighausen, 2006, p. 24; Anti-Atlas; schmidtianus: Goniatites crenistria schmidtianus Nicolaus, 1963, p. 103; Rhenish Mountains [synonym of G. hudsoni]; shimanskyi: Goniatites shimanskyi Bogoslovskaya, 1966, p. 43; South Urals; sphaericus: Conchiliolithus Nautilites sphaericus Martin, 1809, pl. 7; Derbyshire [nomen nudum; synonym of G. sphaericus Sowerby, 1814]; sphaericus: Goniatites sphaericus Sowerby, 1814, p. 116; Derbyshire; sphaeroides: Goniatites crenifalcatus sphaeroides Bogoslovskaya, 1966, p. 43; South Urals; spirifer: Goniatites spirifer Roemer, 1850, p. 51; Harz; stenumbilicatus: Goniatites (Goniatites) stenumbilicatus stenumbilicatus Kullmann, 1961, p. 290; Cantabrian Mountains; sowerbyi: Goniatites sowerbyi sp. nov.; Antler Foreland Basin, Nevada-Utah; tympanus: Goniatites tympanus Korn, Bockwinkel \& Ebbighausen, 2007, p. 142; Anti-Atlas; undatus: Goniatites undatus Kumpera, 1975, p. 13; North Moravia; vesica: Goniatites vesica Phillips, 1836, p. 43; Yorkshire [synonym of G. crenistria]; wedberensis: Goniatites wedberensis Bisat, 1934, p. 304; Yorkshire. 


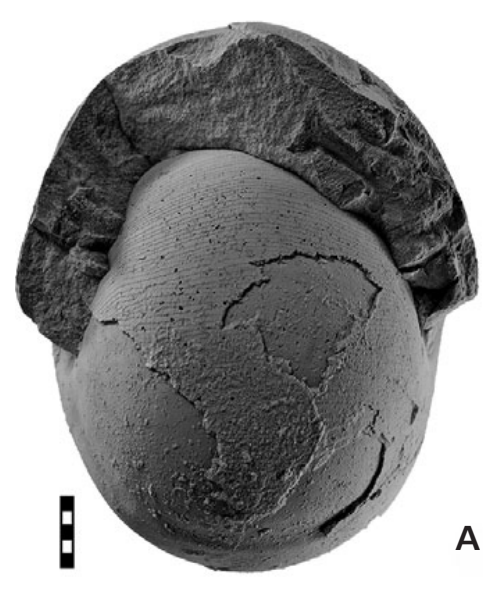

A
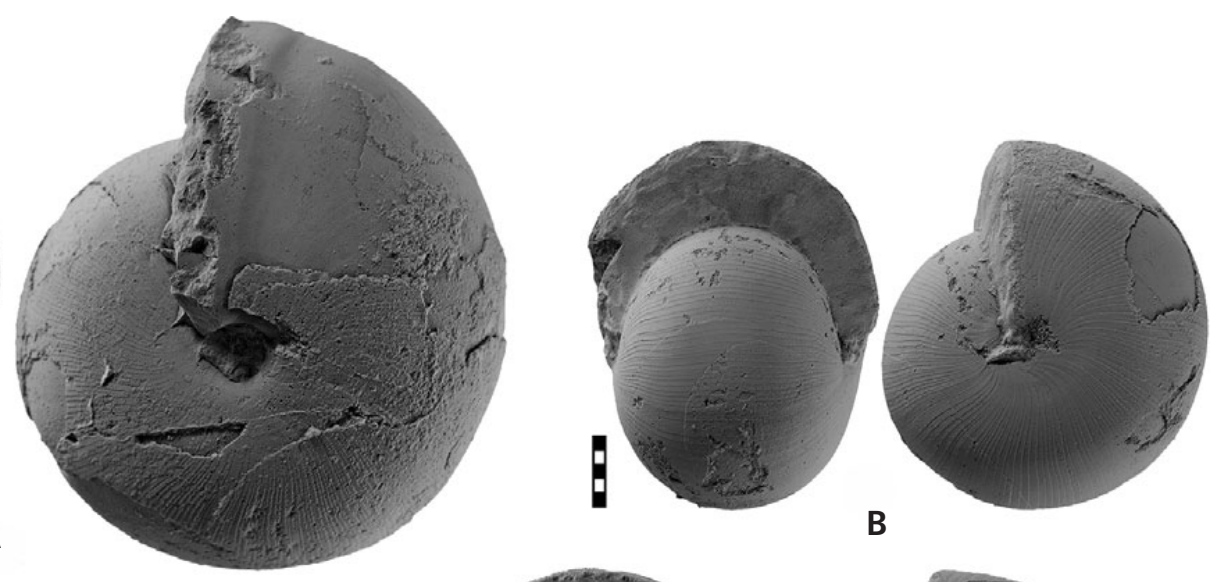

B

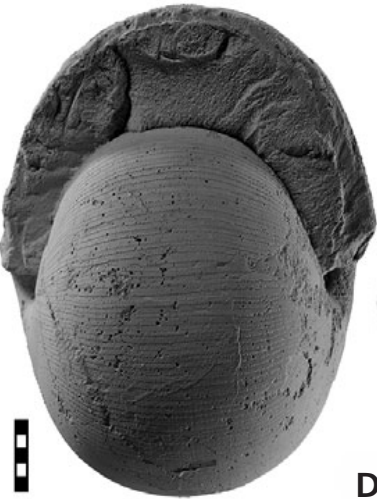

D

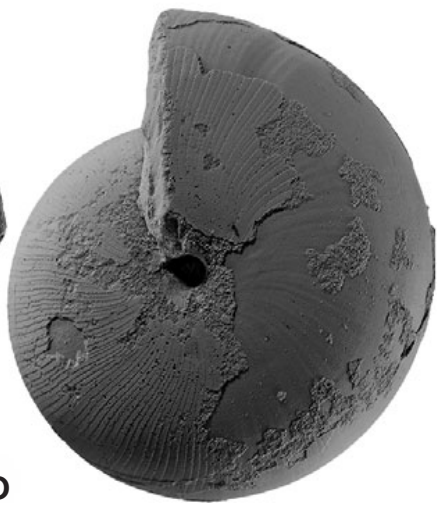

Figure 40. Goniatites americanus Gordon, 1971 from the Calygirtyoceras arcticum Biozone of localities in Utah. • A - specimen UMNH IP 3450 from bed 17 (sample 07UTJU-1) of Granite Mountain North; × 1.5. • B - specimen MB.C.12013.1 from bed 15 of Granite Mountain South; $\times 1.5$. C - specimen MB.C.12016.1 from bed 8 of Middle Confusion Range $1 ; \times 1.5$. $\bullet$ D - specimen UMNH IP 3451 from bed 17 (sample 07UTJU-1) of Granite Mountain North; $\times 1.5$.

Discussion. - Goniatites is a diverse genus with an almost global distribution, encompassing nearly 40 species, of which about 15 are synonyms. As discussed by Korn et al. (2005), the genus appears suddenly in the late Asbian with an almost global distribution. A possible predecessor, Progoniatites, has a similar conch and sutural morphology, but occurs in the early Late Tournaisian (Korn et al. 2003b, 2010). There is no record of intermediate forms in the latest Tournaisian or Early and Middle Viséan.

All species of Goniatites display a very similar conch geometry, conch ontogeny, and suture line, which do not allow the subdivision into distinct morphological groups. A putative criterion for a subdivision of the genus, e.g. the ornament possessing or lacking spiral lines, cannot be used since it is obviously not an apomorphic character of a distinct clade but occurs iteratively in the genus.

\section{Goniatites americanus Gordon, 1971}

Figures 40-44

1957 Goniatites crenistria Phillips; Gordon, p. 42, pl. 5, figs $1-8,12-16$ (not figs 9-11), text-fig. 17A-D.
1965 Goniatites aff. G. crenistria Phillips; Gordon, p. 187 (part), text-figs 44A, B.

1970 Goniatites americanus Gordon; Gordon, p. 821 (part) [nomen nudum], text-fig. 2 (Great Basin Region only).

1971 Goniatites americanus Gordon; p. C41, text-fig. 3.

1972 Goniatites crenistria Phillips; Drahovzal, p. 36, text-fig. 17A.

1984 Goniatites americanus Gordon; Webster et al., p. 31, text-fig. 12.

1995 Goniatites cf. crenistria Phillips; Sadlick, p. 12.

Holotype. - Specimen USNM 170616, illustrated by Gordon (1971) in text-figures 31-o.

Type locality and horizon. - North-eastern slope of Granite Mountain; Camp Canyon Member of Chainman Formation, Calygirtyoceras arcticum Biozone.

Material. - 892 specimens; conch diameter up to $61 \mathrm{~mm}$. The largest specimens are still fully chambered, so that a maximum diameter of the species of about $90 \mathrm{~mm}$ can be estimated. 

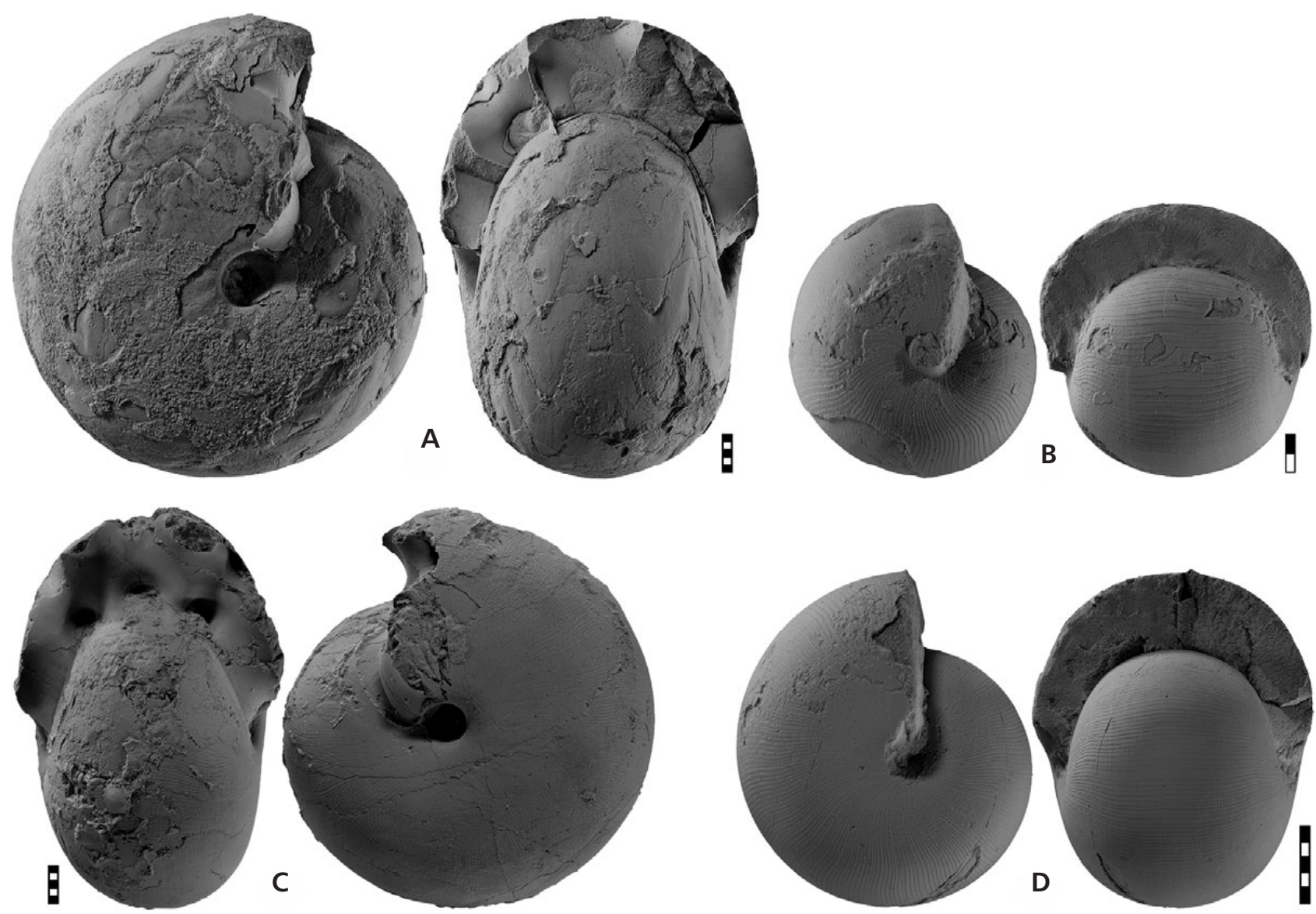

Figure 41. Goniatites americanus Gordon, 1971 from the Girtyoceras primum Biozone of localities in Utah. • A - specimen MB.C.12025.1 from bed 25 of Granite Mountain South; $\times 1.0$. $•$ B - specimen MB.C.12017.1 from bed 12 of Middle Confusion Range 1; $\times 2.5$. C - specimen UMNH IP 3754 from bed 25 (sample 94UTJU-9) of Granite Mountain South; $\times 1.0$. $\bullet$ D - specimen UMNH IP 3526 from bed 13 (sample 97UTMI-12) of Jensen Wash; $\times 2.0$.

Diagnosis. - Goniatites with globular to spindle-shaped conch between 2 and $8 \mathrm{~mm}$ diameter ( $\mathrm{ww} / \mathrm{dm}=0.90-1.15$ ), thickly pachyconic to globular conch (ww/dm $=0.80-1.00)$ at $20 \mathrm{~mm}$ diameter and pachyconic conch $(\mathrm{ww} / \mathrm{dm}=$ $0.65-0.85)$ at $30 \mathrm{~mm}$ diameter. Umbilicus moderate in early ontogeny (uw/dm $=0.20-0.35$ at $2 \mathrm{~mm}$ diameter) and very narrow in all stages larger than $4 \mathrm{~mm}$ diameter (uw/dm $=0.01-0.10)$. Umbilical wall incurved in late growth stages. Aperture low (WER $=1.60-1.90)$ at $30 \mathrm{~mm}$ diameter. Ornament with crenulated, slightly biconvex and rursiradiate growth-lines; external sinus shallow. Some very fine spiral lines around the umbilicus. Suture line at $25 \mathrm{~mm}$ conch diameter with very narrow or narrow external lobe ( 0.50 of the external lobe depth; 1.15 of the ventrolateral saddle width), and low median saddle ( 0.30 of the external lobe depth). External lobe Y-shaped with very narrow, V-shaped prongs; ventrolateral saddle acute.

Description. - Goniatites americanus is represented by a large number of well-preserved specimens, and a total of 12 cross sections (some of them illustrated in Figs 42A and
43A-F) were produced to study the ontogenetic changes and intraspecific variability of the species. The morphometric plots (Figs 42E-G, 43M-O) show that two distinct ontogenetic intervals can be separated, of which the first one ranges up to about $6 \mathrm{~mm}$ conch diameter. This stage is characterized by an increasing conch width from ww/dm = $0.75-0.90$ at $1 \mathrm{~mm}$ diameter to $\mathrm{ww} / \mathrm{dm}=0.90-1.15$ at $6 \mathrm{~mm}$ diameter. At the same time, the umbilicus, which is slightly opened in the early juvenile stage (uw/dm = $0.25-0.35$ at $2 \mathrm{~mm}$ diameter), is almost completely closed. The second growth interval, beginning at about $6 \mathrm{~mm}$ diameter, leads to a more slender adult conch shape. The $\mathrm{ww} / \mathrm{dm}$ ratio is reduced to $0.65-0.85$ at $30 \mathrm{~mm}$ diameter, and the umbilicus remains almost closed (uw/dm = $0.00-0.05)$. In the second growth interval, the aperture becomes slightly higher, expressed in a whorl expansion rate between 1.60 and 1.90 at 20-30 mm diameter.

The morphometric plots demonstrate wide morphological range within the material, particularly in the ww/dm ratio and the whorl expansion rate (Figs 43M, O, 44R) between growth stages of 7 and $30 \mathrm{~mm}$ conch diameter. In the 

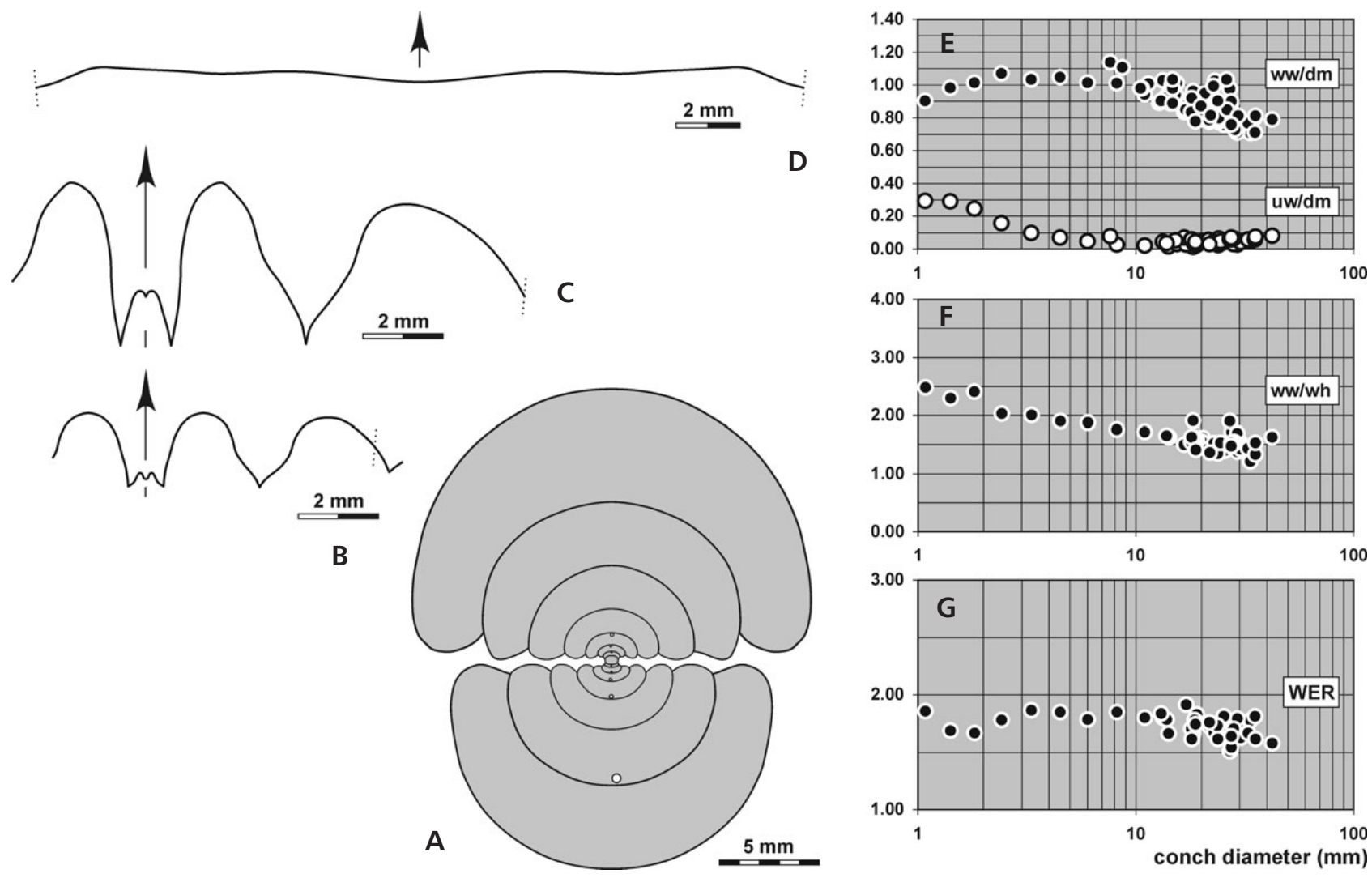

Figure 42. Goniatites americanus Gordon, 1971 from the Calygirtyoceras arcticum Biozone of localities in Utah. • A - cross section of specimen MB.C.12013.2 from bed 15 of Granite Mountain South; × 2.5. • B - suture line of specimen MB.C.12016.2 from bed 8 of Middle Confusion Range, at $7.7 \mathrm{~mm} \mathrm{dm}, 8.8 \mathrm{~mm}$ ww; $\times 5.0$. $\bullet \mathrm{C}-$ suture line of specimen MB.C.12016.3 from bed 8 of Middle Confusion Range, at $12.0 \mathrm{~mm}$ ww; $\times 5.0 . \bullet \mathrm{D}-$ growth line course of specimen MB.C.12013.1 from bed 15 of Granite Mountain South, at $20.3 \mathrm{~mm}$ diameter, $17.5 \mathrm{~mm}$ wh, $10.1 \mathrm{~mm}$ ww; $\times 4.0$. - E-G - ontogenetic development of the conch width index (ww/dm), umbilical width index (uw/dm), and whorl expansion rate (WER) of all available specimens.

ww/dm ratio, the position of the middle two quartiles lies always in a narrow zone near the lower end, meaning that skewing is particularly well expressed towards thicker conchs. The uw/dm ratio appears to be less variable, but this is obviously due to the fact that an almost closed umbilicus does not allow much geometric variance. In the ww/dm ratio, the range of variability is 0.25 throughout ontogeny, and sometimes even higher when some rare outli- ers are included. The uw/dm ratio has a range of variability of 0.15 up to $8 \mathrm{~mm}$ conch diameter, and later decreasing because of the known reasons. In the WER plot, a variability range of 0.30 is expressed above $3 \mathrm{~mm}$ diameter.

Specimen MB.C.12014.4 (Fig. 43F) from bed 25 (Girtyoceras primum Biozone) of Granite Mountain, with a maximum diameter of nearly $26 \mathrm{~mm}$, can be regarded as a characteristic morphological representative of the species

Figure 43. Goniatites americanus Gordon, 1971 from the Girtyoceras primum Biozone of localities in Utah. • A - cross section of specimen MB.C.12019.1 from bed 10 of Middle Confusion Range 2; × 2.5. • B - cross section of specimen MB.C.12019.2 from bed 10 of Middle Confusion Range 2; $\times 2.5$. C - cross section of specimen MB.C.12014.1 from bed 25 of South Granite Mountain; $\times 2.5$. D - cross section of specimen MB.C.12014.2 from bed 25 of South Granite Mountain; $\times 2.5$. E - cross section of specimen MB.C.12014.3 from bed 25 of South Granite Mountain; $\times 2.5$. $\cdot \mathrm{F}$ - cross section of specimen MB.C.12014.4 from bed 25 of South Granite Mountain; $\times 2.5 . \bullet \mathrm{G}-$ suture line of specimen UMNH IP 3757 from bed 25 (sample 94UTJU-9) of Granite Mountain South, at $19.9 \mathrm{~mm}$ diameter, $17.1 \mathrm{~mm}$ ww, $10.5 \mathrm{~mm}$ wh; $\times 3.0 . \cdot \mathrm{H}-$ suture line of specimen MB.C.12017.2 from bed 12 of Middle Confusion Range 1, at $24.6 \mathrm{~mm}$ diameter, $19.6 \mathrm{~mm}$ ww, $11.2 \mathrm{~mm}$ wh; $\times 3.0$. $\bullet$ I - suture line of specimen UMNH IP 3392 from bed 25 (sample 05UTJU-12) of Granite Mountain South, at $25.6 \mathrm{~mm}$ diameter, $20.9 \mathrm{~mm} \mathrm{ww}, 12.2 \mathrm{~mm}$ wh; $\times 3.0$. $\bullet \mathrm{J}-$ suture line of specimen UMNH IP 3754 from bed 25 (sample 05UTJU-12) of Granite Mountain South, at $51.5 \mathrm{~mm}$ diameter, $34.2 \mathrm{~mm}$ ww, $26.0 \mathrm{~mm}$ wh; $\times 2.0$. $\bullet \mathrm{K}-$ growth line course of specimen UMNH IP 3755 from bed 25 (sample 94UTJU-9) of Granite Mountain South, at $24.9 \mathrm{~mm}$ diameter, $19.6 \mathrm{~mm}$ ww, $13.6 \mathrm{~mm}$ wh; $\times 4.0$. - L - growth line course of specimen UMNH IP 3754 from bed 25 (sample 05UTJU-12) of Granite Mountain South, at $46.5 \mathrm{~mm}$ diameter, $30.8 \mathrm{~mm}$ ww, $21.0 \mathrm{~mm}$ wh; $\times 2.0 . \cdot \mathrm{M}-\mathrm{O}-$ ontogenetic development of the conch width index (ww/dm), umbilical width index (uw/dm), and whorl expansion rate (WER) of all available specimens. 
Dieter Korn \& Alan L. Titus • Goniatites Zone (middle Mississippian) ammonoids, Nevada and Utah
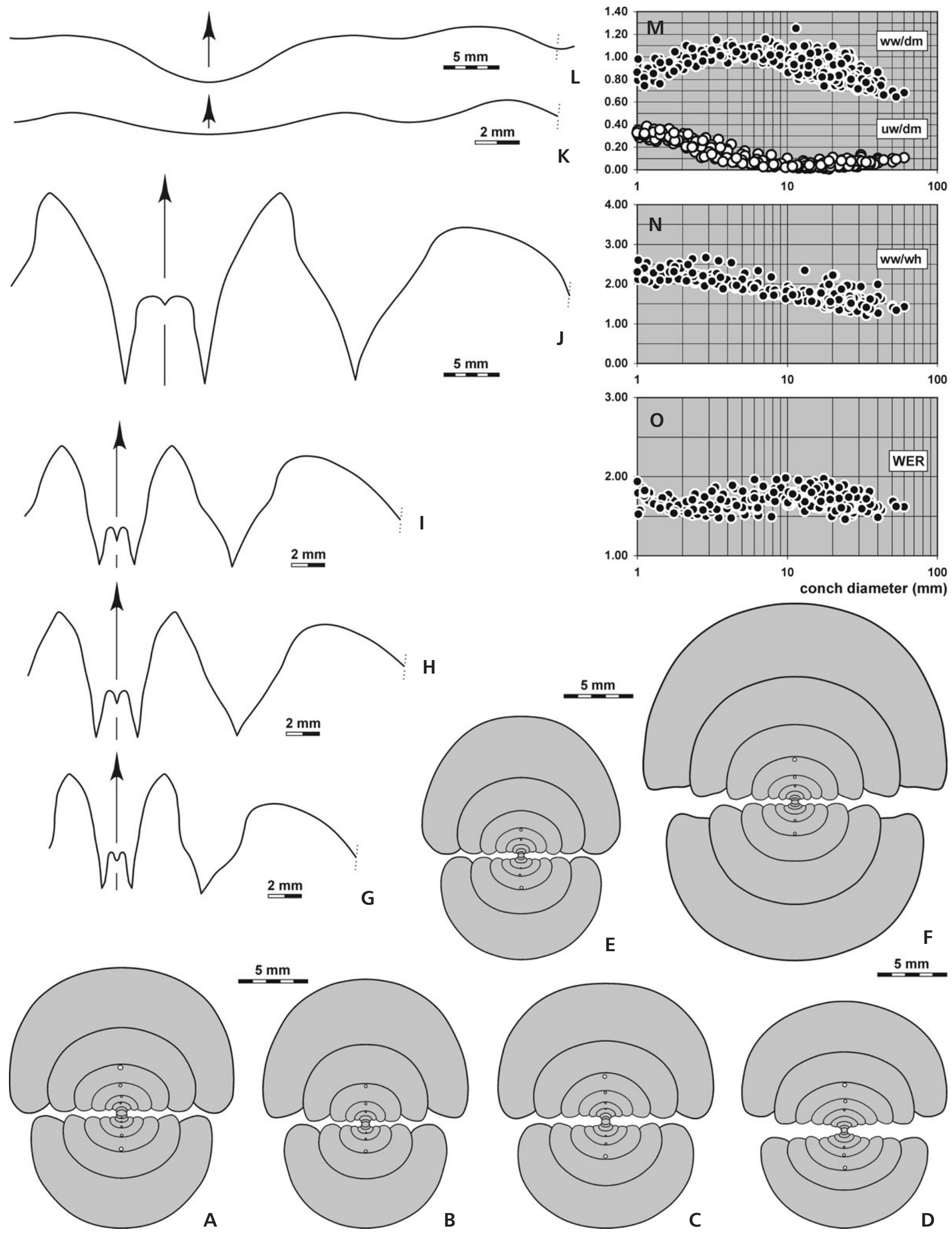
Table 22. Conch ontogeny (Figs 42, 43) of Goniatites americanus Gordon, 1971.

\begin{tabular}{|c|c|c|c|}
\hline $\mathrm{dm}$ & conch shape & whorl cross section shape & aperture \\
\hline $1.5 \mathrm{~mm}$ & $\begin{array}{l}\text { globular; subinvolute or subevolute } \\
(\mathrm{ww} / \mathrm{dm}=0.85-1.00 ; \mathrm{uw} / \mathrm{dm}=0.25-0.35)\end{array}$ & $\begin{array}{l}\text { strongly depressed; strongly embracing } \\
(\mathrm{ww} / \mathrm{wh}=2.10-2.50 ; \mathrm{IZR}=0.40-045)\end{array}$ & low $($ WER $=1.60-1.75)$ \\
\hline $5 \mathrm{~mm}$ & $\begin{array}{l}\text { globular or spindle-shaped; involute } \\
(\mathrm{ww} / \mathrm{dm}=0.95-1.15 ; \mathrm{uw} / \mathrm{dm}=0.05-0.15)\end{array}$ & $\begin{array}{l}\text { strongly depressed; very strongly embracing } \\
(\mathrm{ww} / \mathrm{wh}=2.10-2.50 ; \mathrm{IZR}=0.50-0.60)\end{array}$ & low or moderate $(\mathrm{WER}=1.50-1.85)$ \\
\hline $10 \mathrm{~mm}$ & $\begin{array}{l}\text { globular or spindle-shaped; involute } \\
(\mathrm{ww} / \mathrm{dm}=0.85-1.25 ; \mathrm{uw} / \mathrm{dm}=0.00-0.10)\end{array}$ & $\begin{array}{l}\text { moderately depressed; very strongly embracing } \\
(\mathrm{ww} / \mathrm{wh}=1.60-1.95 ; \mathrm{IZR}=0.50-0.60)\end{array}$ & low or moderate $(\mathrm{WER}=1.65-2.00)$ \\
\hline $25 \mathrm{~mm}$ & $\begin{array}{l}\text { thickly pachyconic or globular; involute } \\
(\mathrm{ww} / \mathrm{dm}=0.75-1.00 ; \mathrm{uw} / \mathrm{dm}=0.00-0.10)\end{array}$ & $\begin{array}{l}\text { weakly or mod. depr.; very strongly embracing } \\
(\mathrm{ww} / \mathrm{wh}=1.35-1.85 ; \mathrm{IZR}=0.50-0.60)\end{array}$ & low to moderate $($ WER $=1.50-1.85)$ \\
\hline $55 \mathrm{~mm}$ & $\begin{array}{l}\text { pachyconic; involute } \\
(\mathrm{ww} / \mathrm{dm}=0.65-0.75 ; \mathrm{uw} / \mathrm{dm}=0.05-0.10)\end{array}$ & $\begin{array}{l}\text { weakly depressed; very strongly embracing } \\
(\mathrm{ww} / \mathrm{wh}=1.25-1.45 ; \mathrm{IZR}=0.50-0.60)\end{array}$ & low $($ WER $=1.60-1.65)$ \\
\hline
\end{tabular}

Table 23. Conch dimensions (in $\mathrm{mm}$ ) and proportions for reference specimens of Goniatites americanus Gordon, 1971 from the Calygirtyoceras arcticum Biozone.

\begin{tabular}{lccccccccccc}
\hline & $\mathrm{dm}$ & ww & wh & uw & ah & ww/dm & ww/wh & uw/dm & WER & IZR \\
\hline UMNH IP 3450 & 37.4 & 31.1 & 20.5 & 3.3 & 8.3 & 0.83 & 1.52 & 0.09 & 1.66 & 0.59 \\
UMNH IP 3451 & 33.5 & 25.3 & 18.9 & 1.9 & 8.3 & 0.75 & 1.34 & 0.06 & 1.76 & 0.56 \\
MB.C.12016.1 & 29.3 & 23.4 & 13.8 & 1.6 & 7.1 & 0.80 & 1.70 & 0.05 & 1.74 & 0.48 \\
MB.C.12013.1 & 25.5 & 20.4 & 14.2 & 1.1 & 6.3 & 0.80 & 1.43 & 0.04 & 1.76 & 0.56 \\
MB.C.12013.2 & 24.0 & 19.9 & 13.1 & 0.6 & 5.6 & 0.83 & 1.52 & 0.03 & 1.71 & 0.57 \\
\hline
\end{tabular}

Table 24. Conch dimensions (in $\mathrm{mm}$ ) and proportions for reference specimens of Goniatites americanus Gordon, 1971 from the Girtyoceras primum Biozone.

\begin{tabular}{|c|c|c|c|c|c|c|c|c|c|c|}
\hline & $\mathrm{dm}$ & ww & wh & uw & ah & ww/dm & ww/wh & $\mathrm{uw} / \mathrm{dm}$ & WER & IZR \\
\hline MB.C. 12025.1 & 60.1 & 41.1 & 28.8 & 6.5 & 12.9 & 0.68 & 1.43 & 0.11 & 1.62 & 0.55 \\
\hline UMNH IP 3754 & 53.2 & 34.4 & 25.6 & 4.9 & 11.5 & 0.65 & 1.34 & 0.09 & 1.62 & 0.55 \\
\hline MB.C.12014.4 & 25.9 & 22.0 & 13.5 & 1.8 & 5.3 & 0.85 & 1.63 & 0.07 & 1.58 & 0.61 \\
\hline UMNH IP 3367 & 25.6 & 19.4 & 13.9 & 0.9 & 6.2 & 0.76 & 1.39 & 0.03 & 1.74 & 0.55 \\
\hline UMNH IP 3756 & 22.2 & 17.0 & 12.6 & 0.5 & 5.9 & 0.77 & 1.35 & 0.02 & 1.86 & 0.53 \\
\hline UMNH IP 3526 & 22.1 & 18.5 & 11.5 & 0.8 & 5.3 & 0.84 & 1.61 & 0.04 & 1.72 & 0.54 \\
\hline MB.C.12019.1 & 18.9 & 16.3 & 10.6 & 0.2 & 4.4 & 0.86 & 1.54 & 0.01 & 1.69 & 0.59 \\
\hline MB.C.12019.2 & 18.1 & 14.8 & 10.0 & 0.5 & 4.7 & 0.82 & 1.48 & 0.03 & 1.84 & 0.53 \\
\hline MB.C.12014.1 & 17.8 & 15.6 & 9.8 & 0.4 & 4.2 & 0.88 & 1.59 & 0.02 & 1.71 & 0.57 \\
\hline MB.C.12014.3 & 17.6 & 14.4 & 10.0 & 0.2 & 4.5 & 0.81 & 1.44 & 0.01 & 1.79 & 0.55 \\
\hline MB.C.12014.2 & 16.4 & 14.8 & 8.4 & 1.5 & 3.7 & 0.90 & 1.77 & 0.09 & 1.66 & 0.56 \\
\hline MB.C.12014.6 & 16.4 & 13.4 & 8.8 & 0.7 & 4.0 & 0.82 & 1.52 & 0.04 & 1.75 & 0.55 \\
\hline MB.C.12017.1 & 14.3 & 14.3 & 8.3 & 0.7 & 3.1 & 0.99 & 1.72 & 0.05 & 1.63 & 0.63 \\
\hline MB.C. 12014.5 & 13.3 & 11.6 & 7.2 & 0.6 & 3.3 & 0.88 & 1.61 & 0.04 & 1.78 & 0.54 \\
\hline
\end{tabular}

because it ranges, in its conch proportions, in the centre of the morphological spectrum. It shows similar whorl cross sections throughout ontogeny, with a C-shaped outline, with whorls embracing the preceding to a high degree (IZR $=0.56-0.62$ between 2 and $26 \mathrm{~mm}$ diameter), and with a whorl expansion rate oscillating between 1.55 and 1.75 . All whorls up to $13 \mathrm{~mm}$ diameter show a broadly rounded umbilical margin and a convex umbilical wall. Later in ontogeny, the umbilical margin becomes more pronounced and the umbilical wall is flattened or even incurved, as shown in the last volution. The conch is widest at the umbilicus.

Specimens MB.C.12014.3 (17.5 mm diameter; Fig. 43E) and MB.C.12014.2 (16.5 mm diameter; Fig. 43D), also from Granite Mountain bed 25, represent the more slender and more globular spectrum of conch geometry. Apart from the ww/dm ratio, these specimens have different apertural heights, causing a whorl expansion rate of 1.80 in the slender specimen MB.C.12014.3 and 1.65 in the globular specimen MB.C.12014.2. 
Figure 44. Goniatites americanus Gordon, 1971, box and whiskers diagrams showing the variability within the conch width index (ww/dm), umbilical width index (uw/dm), and whorl expansion rate (WER) during ontogeny. White boxes refer to the middle two quartiles, black bars refer to the total range within each $\mathrm{D}(\log )$ unit. $\bullet \mathrm{A}, \mathrm{B}-$ specimens from the higher horizons (Girtyoceras primum Biozone). • C, D specimens from the lower horizons (Calygirtyoceras arcticum Biozone).

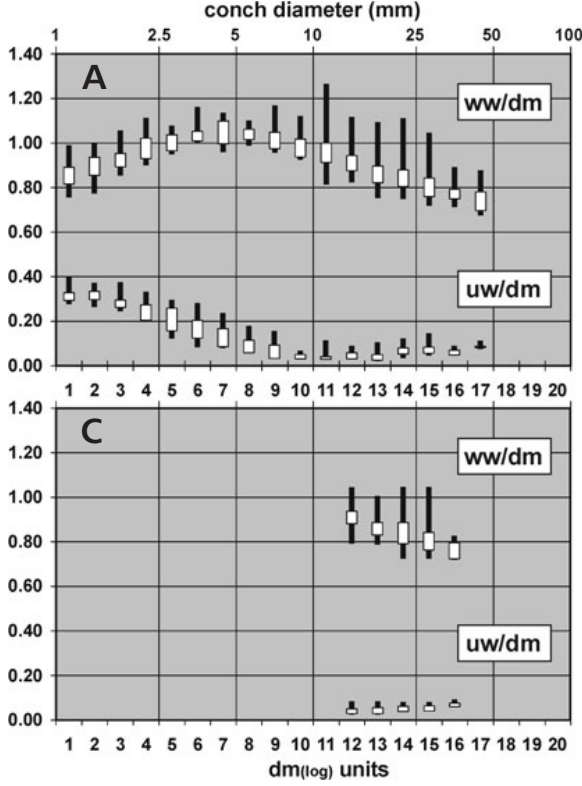

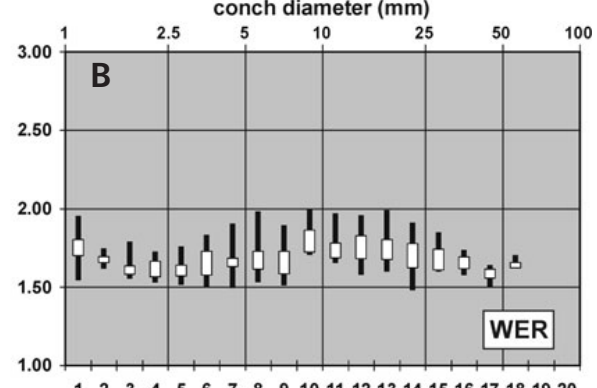

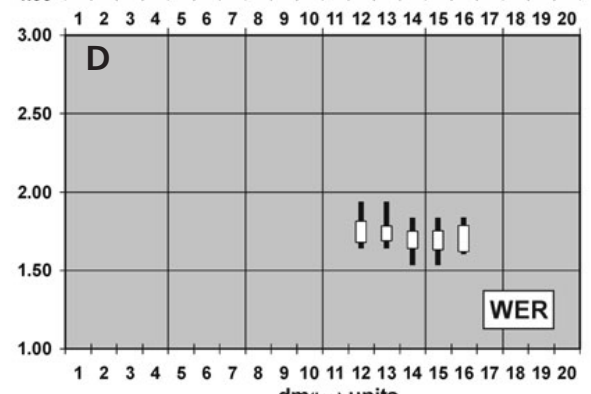

Table 25. Suture line proportions (Figs 42, 43) for Goniatites americanus Gordon, 1971.

\begin{tabular}{lccccccl}
\hline specimen & at dm & EL w/d & EL/VLS & EL/AL & MS h & VLS w/h & remarks \\
\hline UMNH IP 3754 & 51.6 & 0.60 & 1.17 & 1.36 & 0.46 & 0.51 & E lobe Y-shaped \\
UMNH IP 3392 & 25.6 & 0.51 & 1.14 & 0.92 & 0.31 & 0.45 & VL saddle almost symmetric, acute \\
MB.C.12017.2 & 24.6 & 0.49 & 1.05 & 0.85 & 0.29 & 0.46 & VL saddle almost symmetric, acute \\
UMNH IP 3757 & 19.9 & 0.40 & 1.12 & 0.70 & 0.32 & 0.36 & VL saddle narrowly rounded \\
\hline
\end{tabular}

At 53 mm conch diameter, UMNH IP 3754 (Fig. 41C) is one of the largest available specimens. It is still fully chambered. This thinly pachyconic conch $(\mathrm{ww} / \mathrm{dm}=0.65)$ has a very narrow umbilicus (uw/dm $=0.09$ ) and a low aperture $(\mathrm{WER}=1.62)$. The venter is broadly rounded, and the umbilical wall is incurved. Most of the specimen is covered with shell that shows the ornament composed of strongly crenulated growth lines with rursiradiate convex course and very fine spiral lines best visible around the umbilicus.

UMNH IP 3526 (Fig. 41D) is a beautifully preserved specimen with $22 \mathrm{~mm}$ conch diameter. The conch is thickly pachyconic $(\mathrm{ww} / \mathrm{dm}=0.84)$ with an almost closed umbilicus $(\mathrm{uw} / \mathrm{dm}=0.04)$ and a low aperture $(\mathrm{WER}=1.72)$. It is entirely covered with shell that shows the strongly crenulated, slightly biconvex growth lines with a rather high dorsolateral projection and a very shallow ventral sinus.

Smaller specimens show wide variability in their conch shapes. MB.C.12017.1 (14 mm diameter; Fig. 41B), for instance, has an almost spherical shape $(\mathrm{ww} / \mathrm{dm}=0.99)$ with a very narrow umbilicus and a low aperture $(\mathrm{WER}=1.63)$. The shell shows wide-standing crenulated growth lines that possess a dominant dorsolateral projection, a shallow lateral sinus and a broad ventral projection with a very shallow sinus. A shallow constriction, running parallel to the growth lines, is visible on the internal mould.

Suture lines were drawn from specimens in different growth stages. The suture line of the large specimen UMNH IP 3754 (51.5 mm conch diameter; Fig. 43J) has a slightly Y-shaped external lobe with diverging flanks and a median saddle of 0.46 height of the $E$ lobe depth. The prongs of the external lobe are very narrow. The acute ventrolateral saddle has a symmetric shape except for the curvature in its dorsal flank. This curvature of the ventral flank of the adventive lobe occurs in the upper third and causes an indistinct asymmetry of the $\mathrm{V}$-shaped adventive lobe.

Suture lines of smaller specimens are more diagnostic, particularly because they can be compared with specimens of the same size of other species. Specimens MB.C.12017.2 and UMNH IP 3392 (both approximately $25 \mathrm{~mm}$ diameter; Fig. 43H, I) show similar suture lines with a Y-shaped external lobe, in which the upper part diverges stronger. The external lobe is narrower than the adventive lobe, and it has very narrow prongs. A median saddle is raised to 0.3 of the external lobe depth. The ventrolateral saddle is almost symmetric and acute, and the adventive lobe is $\mathrm{V}$-shaped. The difference between the 
two suture lines is the fact that in UMNH IP 3392 the flanks of the lobes are stronger curved than in MB.C.12017.2.

Discussion. - An overemphasis of ornamental criteria for species distinction of North American Goniatites has led to previous workers confusing stratigraphically and suturally distinct forms such as G. americanus and G. eganensis (see synonymy for details). Sutural criteria can be readily used to differentiate $G$. americanus from all other North American species of crenistriate Goniatites. The median saddle of $G$. americanus reaches only 30 percent of the depth of the external lobe, in contrast to the stratigraphically younger species $G$. eganensis and $G$. sowerbyi, in which this value reaches 40 percent. We want to emphasize that true G. americanus has never been found east of the Great Basin.

The European species G. hudsoni bears the closest resemblance to $G$. americanus, and separation can only be achieved when the material is very well preserved. G. hudsoni occurs, like G. americanus, with a wide morphological spectrum including slender and also stout variants (see Korn \& Ebbighausen 2008, text-fig. 22), which are connected by a continuous range of intermediate morphologies. The only criterion for separating the two species is the conspicuous, narrow dorsolateral projection of the growth lines in G. hudsoni. This projection is also present in G. americanus, but is much wider and lower.

G. rodioni from the Anti-Atlas of Morocco shows also some resemblance with $G$. americanus, particularly in conch shape and also shell ornament with a dorsolateral projection of the growth lines, but differs in the much narrower external lobe.

Because the species has such an extended stratigraphic range in the Chainman Formation, we tested the hypothesis that all specimens belong to only one species. Stratigraphically older (e.g. bed 17 of Granite Mountain = Calygirtyoceras arcticum Zone) and younger (e.g. bed 25 of Granite Mountain = Girtyoceras primum Zone) material was analysed separately with respect to ontogenetic trajectories and intraspecific variability (Fig. 44). Results show that that the material represents a large morphological spectrum that cannot be separated into different species. Likewise, the suture lines and shell ornament of these stratigraphically disparate occurrences cannot be subdivided.
Goniatites deceptus sp. nov. Figures 45-50

1970 Goniatites multiliratus Gordon; Gordon (part), p. 821, text-fig. 2 (Great Basin portion only).

1971 Goniatites multiliratus Gordon; Gordon, p. C40, text-fig. 1.

1984 Goniatites multiliratus Gordon; Webster et al., p. 31, text-fig. 12.

1995 Goniatites multiliratus Gordon; Sadlick, p. 3, text-figs $12,13$.

Derivation of name. - From Lat. deceptior $=$ fake, since the material of this species has, in earlier studies, erroneously been attributed to G. multiliratus.

Holotype. - Specimen UMNH IP 3937, illustrated in Fig. 45B.

Type locality and horizon. - Jensen Wash, bed 28; Camp Canyon Member of Chainman Formation, Goniatites deceptus Biozone.

Material. - 266 specimens; conch diameter up to $61 \mathrm{~mm}$.

Diagnosis. - Goniatites with globular conch between 2 and $8 \mathrm{~mm}$ diameter $(\mathrm{ww} / \mathrm{dm}=0.85-1.05)$, pachyconic conch (ww/dm $=0.70-0.80)$ at $20 \mathrm{~mm}$ diameter, and thinly pachyconic conch $(\mathrm{ww} / \mathrm{dm}=0.65-0.70)$ at $30 \mathrm{~mm}$ diameter. Umbilicus moderate in early ontogeny (uw/dm = $0.20-0.30$ at $2 \mathrm{~mm}$ diameter) and very narrow or nearly closed in all stages larger than $4 \mathrm{~mm}$ diameter (uw/dm = 0.01-0.10). Umbilical wall flattened in late growth stages. Aperture low or moderate $(\mathrm{WER}=1.65-1.85$ at $30 \mathrm{~mm}$ diameter). Ornament with crenulated, slightly biconvex and rectiradiate growth-lines; external sinus shallow. 180-200 very fine spiral lines. Suture line at $25 \mathrm{~mm}$ conch diameter with narrow external lobe $(0.50-0.55$ of the external lobe depth; 1.25 of the ventrolateral saddle width), and moderately low median saddle ( 0.40 of the external lobe depth). External lobe Y-shaped with narrow, V-shaped prongs; ventrolateral saddle subangular.

Description. - The biometric plots show that there is only minor intraspecific variability, and that ontogenetic changes are less well developed as in other species of the genus

Figure 45. Goniatites deceptus sp. nov. from localities in Utah, slender variants of the species. • A - paratype UMNH IP 3945 from bed 19 (sample 01UTMI-43) of Conger Mountain West; $\times 1.0$. $・$ B - holotype UMNH IP 3937 from bed 28 of Jensen Wash; $\times 1.25$. $\bullet$ - paratype UMNH IP 3934 from bed 28 (sample 93UTMI-27) of Jensen Wash; $\times 1.25$. $・$ D - paratype UMNH IP 3946 from bed 19 (sample 01UTMI-43) of Conger Mountain West; $\times 1.5$. - E - paratype UMNH IP 3868 from bed 35 (sample 94UTJU-10) of Granite Mountain North; × 2.0. • F - paratype UMNH IP 3938 from bed 28 of Jensen Wash; $\times 2.0 . \bullet \mathrm{G}-$ paratype UMNH IP 3869 from bed 35 (sample 94UTJU-10) of Granite Mountain North; $\times 2.0 . \cdot$ H - paratype UMNH IP 3870 from bed 35 (sample 94UTJU-10) of Granite Mountain North; $\times 2.0$. 
Dieter Korn \& Alan L. Titus • Goniatites Zone (middle Mississippian) ammonoids, Nevada and Utah
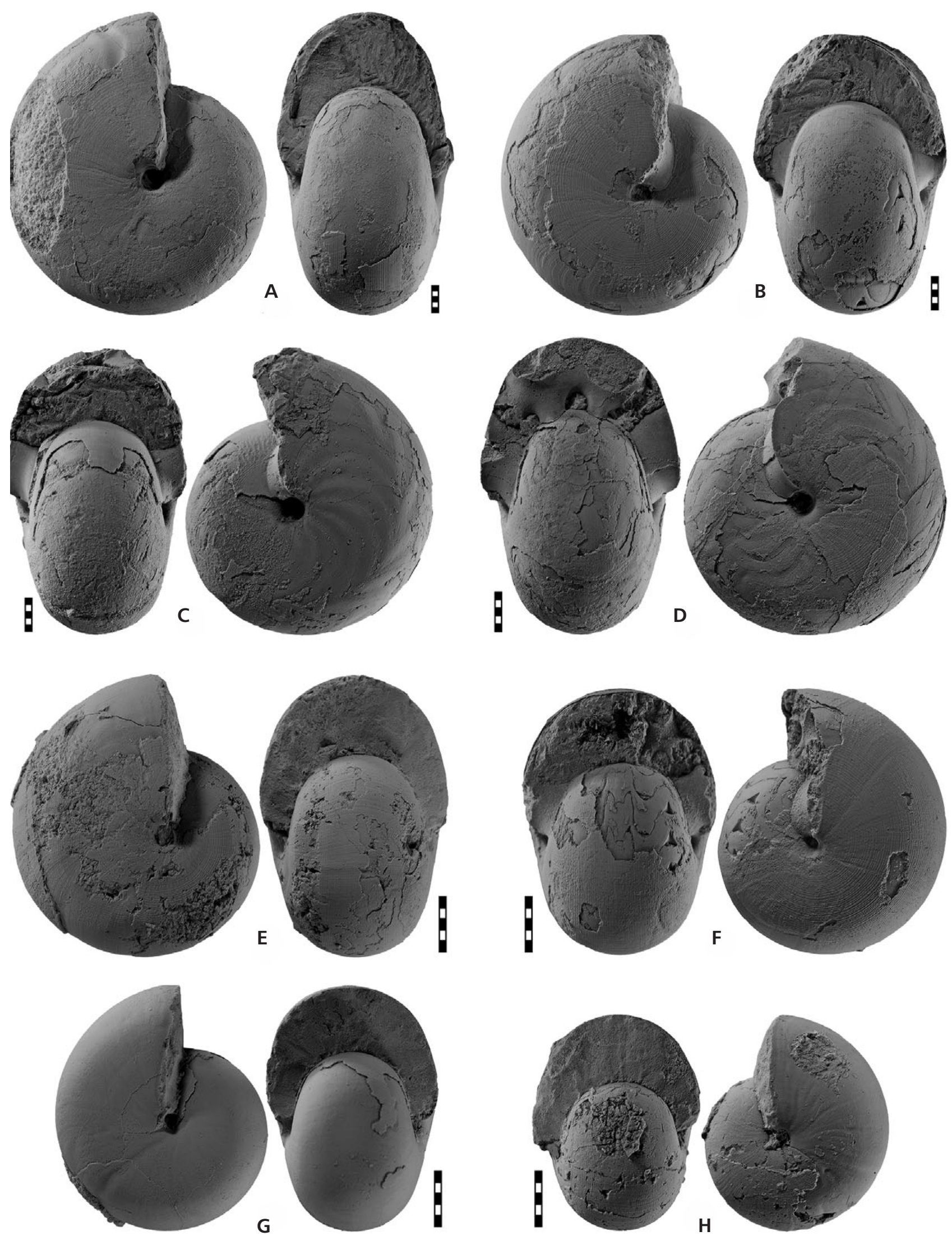


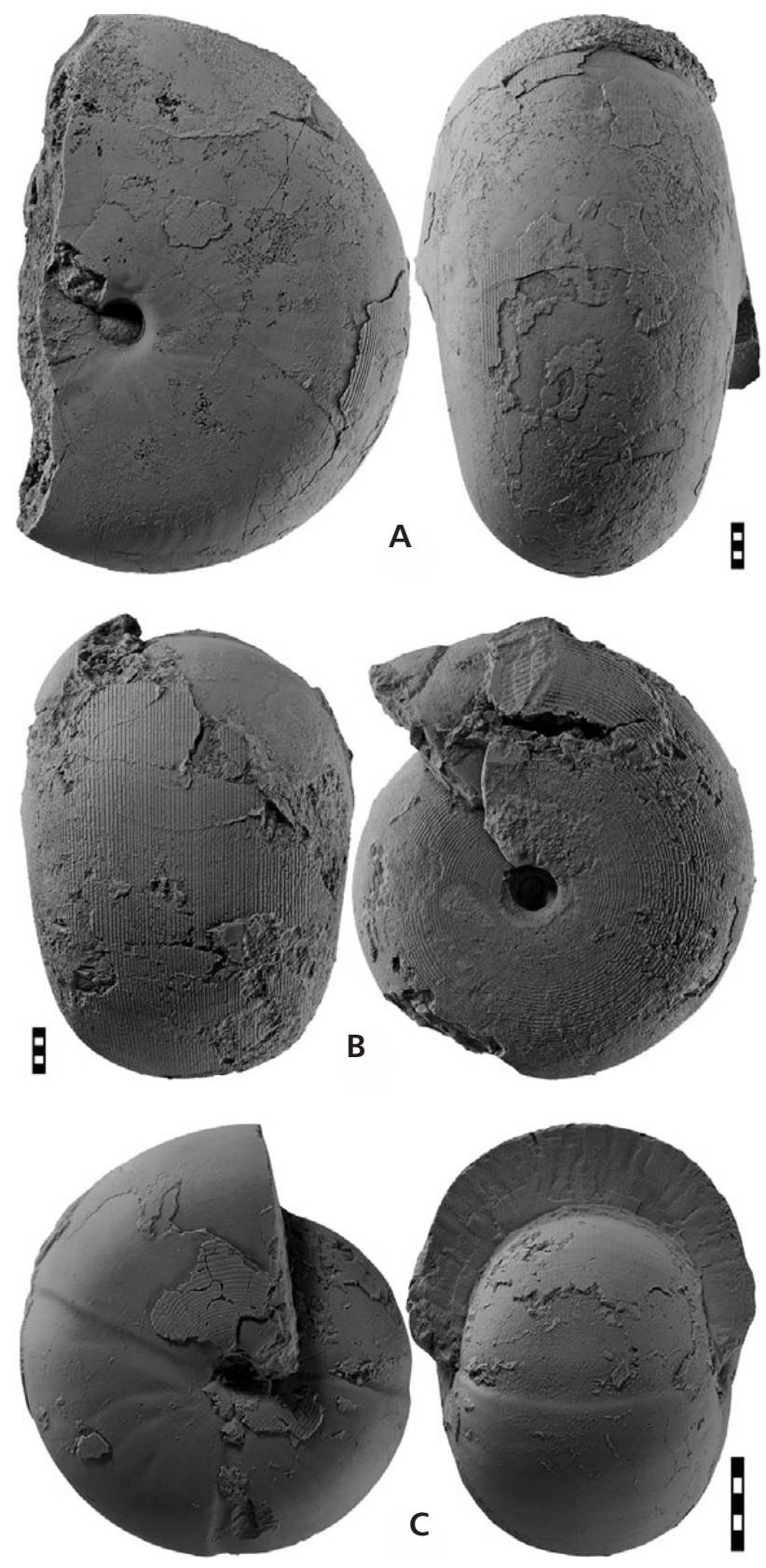

Figure 46. Goniatites deceptus sp. nov. from localities in Utah; stouter variants of the species. • A - paratype UMNH IP 3839 from bed 19 (sample 01UTMI-43) of Conger Mountain West; $\times 1.0$. $\bullet$ B - paratype UMNH IP 3933 from bed 28 (sample 93UTMI-27) of Jensen Wash; $\times 1.0$. - C - paratype MB.C.12026.2 from bed 33 of Granite Mountain North; $\times 2.0$.

(Figs 48G-I, 50H-J). The early juvenile stage is globular at $2 \mathrm{~mm}$ diameter ( $\mathrm{ww} / \mathrm{dm}=0.85-1.00$ ) with a moderately wide umbilicus (uw/dm $=0.20-0.30$ ), followed by a growth interval with a slight increase of the ww/dm index of $0.85-0.93$ between 4 and $8 \mathrm{~mm}$ diameter and an almost complete closure of the umbilicus. The aperture becomes higher during this interval and the whorl expansion rate reaches 2.00 at $7 \mathrm{~mm}$ diameter. Thereafter, the conch becomes continuously more slender and is thinly pachyconic at $30 \mathrm{~mm}$ diameter $(\mathrm{ww} / \mathrm{dm}=0.65-0.70)$.

The sectioned large paratype MB.C.12026.1 shows the entire conch ontogeny up to a diameter of $54 \mathrm{~mm}$ diameter (Fig. 49). It has a globular conch up to $6 \mathrm{~mm}$ diameter and thereafter shows continuous lateral compression. Above about $20 \mathrm{~mm}$ conch diameter, the umbilical wall begins to flatten, and above $30 \mathrm{~mm}$ diameter it is slightly incurved in its section. Sections made from the Duckwater material are similar but differ slightly in that they show more strongly converging flanks (Fig. 50B, C).

Two smaller sectioned paratypes, UMNH IP 3871 and UMNH IP 3872 (Fig. 48A, B), both nearly $20 \mathrm{~mm}$ in diameter, are very similar to each other and differ mainly in the width of the conch. They show the ontogenetic transformation from the ventrally depressed, kidney-shaped whorl cross section to the $\mathrm{C}$-shaped section in later ontogenetic stages, the almost perfect closure of the umbilicus, and the rounded convex umbilical wall.

Holotype UMNH IP 3937 is a well-preserved specimen of $40 \mathrm{~mm}$ conch diameter (Fig. 45B); it is fully chambered and almost entirely covered with the shell. It is thickly pachyconic and involute $(\mathrm{ww} / \mathrm{dm}=0.68 ; \mathrm{uw} / \mathrm{dm}=0.06$ ) with a narrowly rounded umbilical margin and a broadly rounded venter. The shell is decorated with faint spiral lines, approximately 200 from umbilicus to umbilicus, which are arranged in irregular distances and which are stronger around the umbilicus and the inner flanks. The growth lines are much finer than the spiral lines; they extend with a biconvex course, forming low lateral projections and a rather deep ventral sinus.

Paratype UMNH IP 3945 (55 mm diameter; Fig. 45A) represents the adult stage of the species. It is thickly discoidal $(\mathrm{ww} / \mathrm{dm}=0.59)$ with a very narrow umbilicus (uw/dm $=0.07$ ) and is a slender variant of the species. The specimen has a low aperture $(\mathrm{WER}=1.74)$. Some parts are covered with shell, which display a delicate ornament of fine biconvex growth lines and extremely fine spiral ornament that is missing in a narrow zone around the umbilicus and more prominent on the venter.

Paratype UMNH IP 3933 (49 mm diameter; Fig. 46B) from Jensen Wash is a stout variant of the species (ww/dm $=0.74$ ), with a characteristic wide and slightly depressed venter. The spiral lines are similarly strong on flanks and venter.

Paratype UMNH IP 3934 (39 mm diameter; Fig. 45C), also from Jensen Wash, is more slender $(\mathrm{ww} / \mathrm{dm}=0.63)$. In its dorsal portion, the shell is covered by patches of wrinkle layer, which themselves are covered by an almost smooth shell layer with traces of exceedingly fine spiral lines.

Paratype UMNH IP 3868 (Fig. 45E) at $26 \mathrm{~mm}$ conch diameter, is a moderate-sized individual. It is thinly 

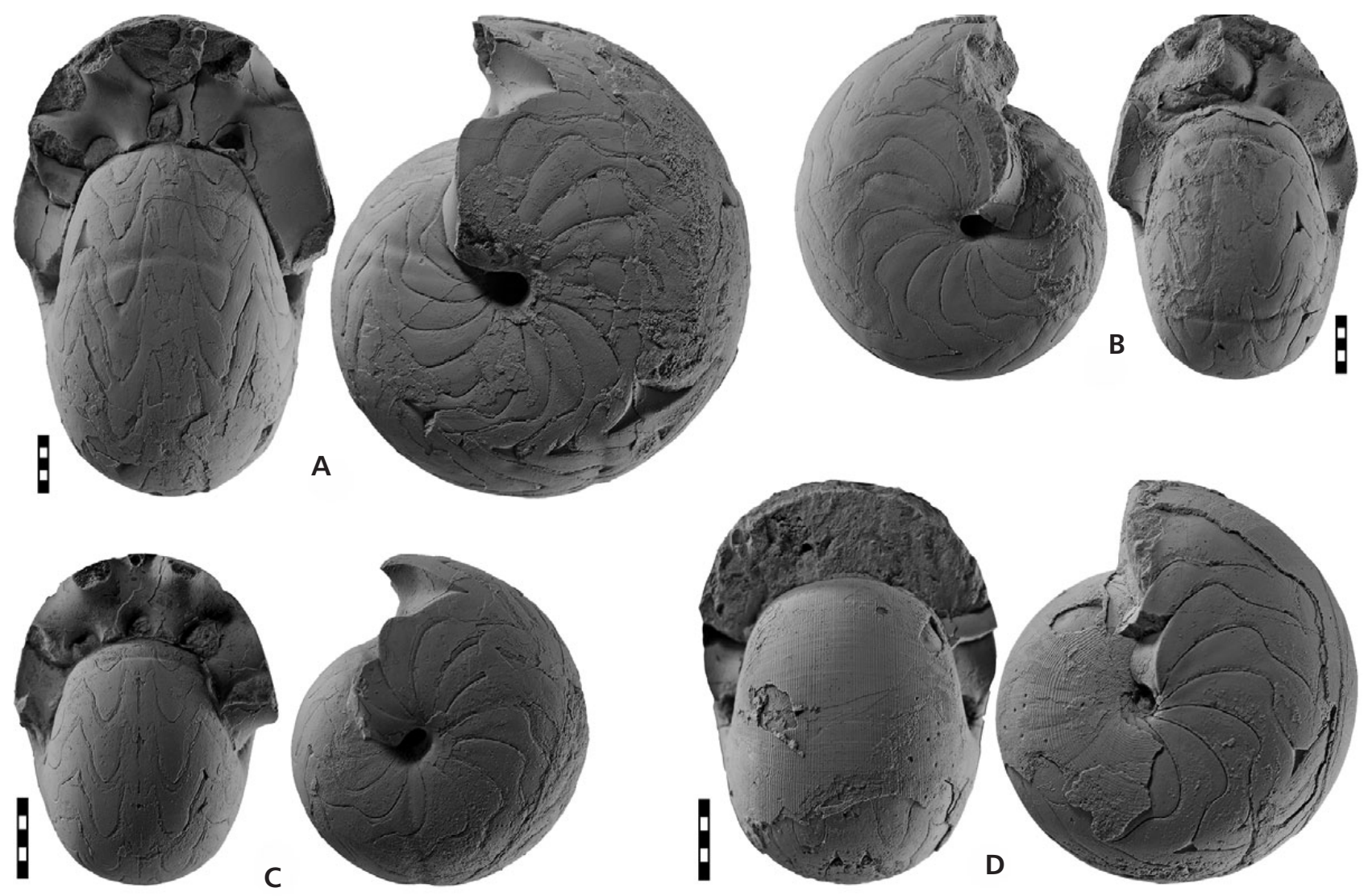

Figure 47. Goniatites deceptus sp. nov. from localities in Nevada. $\bullet$ A - paratype UMNH IP 3845 from bed 4 (sample 93NVNY-1) of Duckwater Hills; $\times 1.5$. $・$ B - paratype UMNH IP 3846 from bed 4 (sample 93NVNY-1) of Duckwater Hills; $\times 1.5$. $\cdot$ C - paratype UMNH IP 3847 from bed 4 (sample 93NVNY-1) of Duckwater Hills; $\times 2.0$. $・$ D - paratype MB.C.12027.1 from Cathedral Canyon; $\times 2.0$. $\bullet$ E - paratype MB.C.12027.2 from Cathedral Canyon; $\times 1.5$.
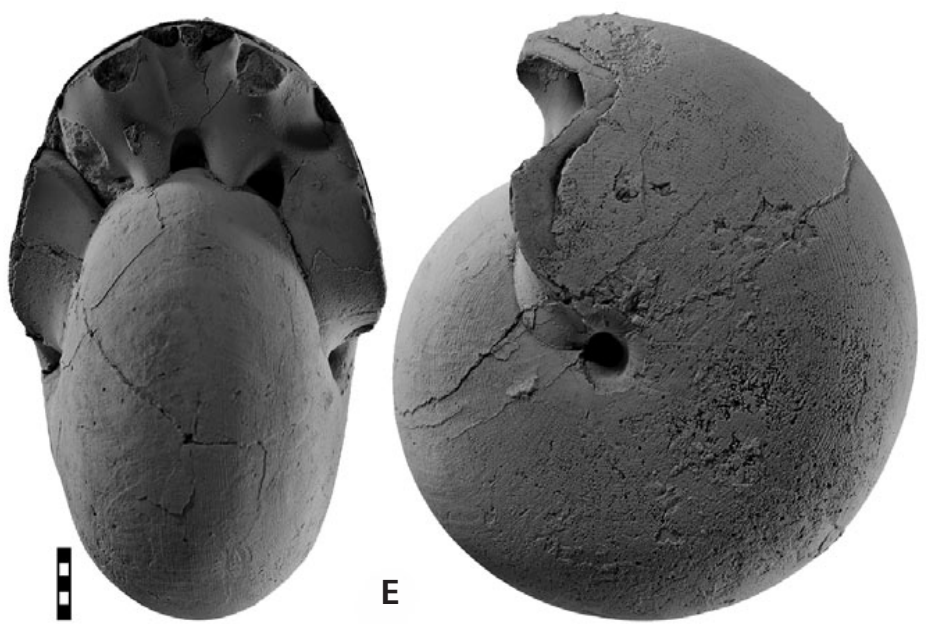

pachyconic $(\mathrm{ww} / \mathrm{dm}=0.67)$ with an almost closed umbilicus (uw/dm $=0.04)$ and a rather high aperture $(\mathrm{WER}=1.92)$. Shell is well preserved in specimen UMNH IP 3868; showing fine spiral lines and delicate, slightly biconvex growth lines. The internal mould of the smaller paratype UMNH IP 3869 (22.5 mm dm; Fig. 45G) has a few irregularly spaced constrictions running parallel to the growth lines.

UMNH IP 3870 is a small paratype (almost $20 \mathrm{~mm}$ diameter; Fig. 45H) that shows similar conch proportions. Growth lines and constrictions of the internal mould have a very shallow lateral sinus, a low ventrolateral projection,

and a shallow ventral sinus. Juvenile specimens such as UMNH IP 3875 (8 $\mathrm{mm}$ diameter) are thickly pachyconic and show almost straight constrictions.

Paratype MB.C.12026.2 (25 mm diameter; Fig. 46C) belongs to the thicker, more cuboid end of the morphological spectrum $(\mathrm{ww} / \mathrm{dm}=0.80)$, which exhibit an almost completely closed umbilicus. This specimen's shell is ornamented with 180 fine and regularly spaced spiral lines and very fine growth lines. Specimen MB.C.12026.2 has constrictions on the internal mould, which stand almost precisely $90^{\circ}$ apart. 

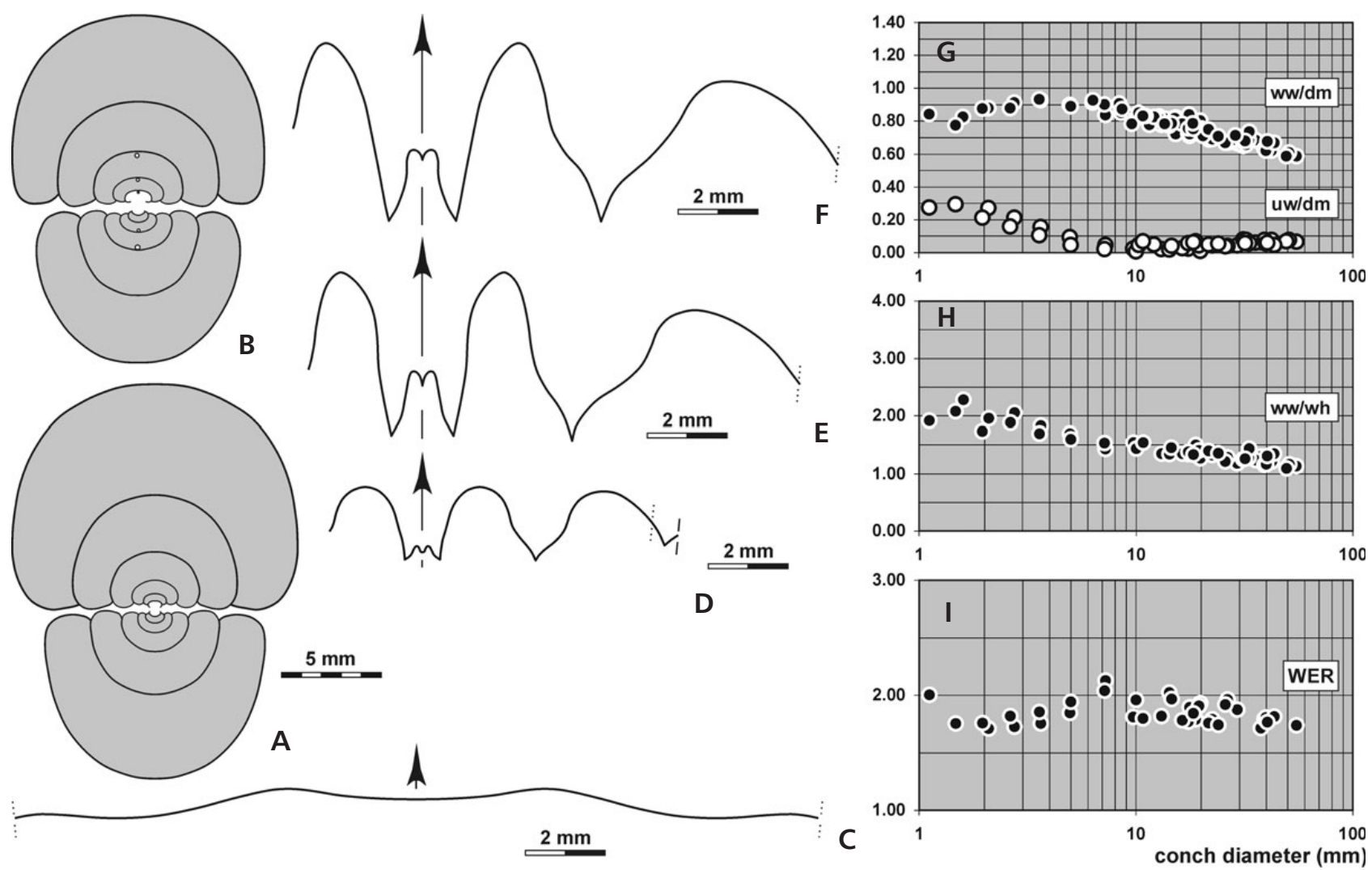

Figure 48. Goniatites deceptus sp. nov. from bed 35 (sample 94UTJU-10) of Granite Mountain North (Utah). • A - cross section of paratype UMNH IP $3871 ; \times 2.5$. $\bullet$ B - cross section of paratype UMNH IP $3872 ; \times 2.5$. $\bullet$ C - growth line course of paratype UMNH IP 3870 , at 17.0 mm diameter; $\times 5.0$. $\bullet$ D - suture line of paratype UMNH IP 3873 , at $7.7 \mathrm{~mm}$ diameter, $8.8 \mathrm{~mm}$ ww; $\times 5.0$. $\bullet$ E - suture line of paratype UMNH IP 3874 , at $12.0 \mathrm{~mm}$ ww; $\times 5.0$. - F - suture line of paratype UMNH IP 3870 , at $15.0 \mathrm{~mm}$ diameter, $12.4 \mathrm{~mm}$ ww; $\times 5.0$. $\bullet \mathrm{G}-\mathrm{I}-$ ontogenetic development of the conch width index (ww/dm), umbilical width index (uw/dm), and whorl expansion rate (WER) of all available specimens.

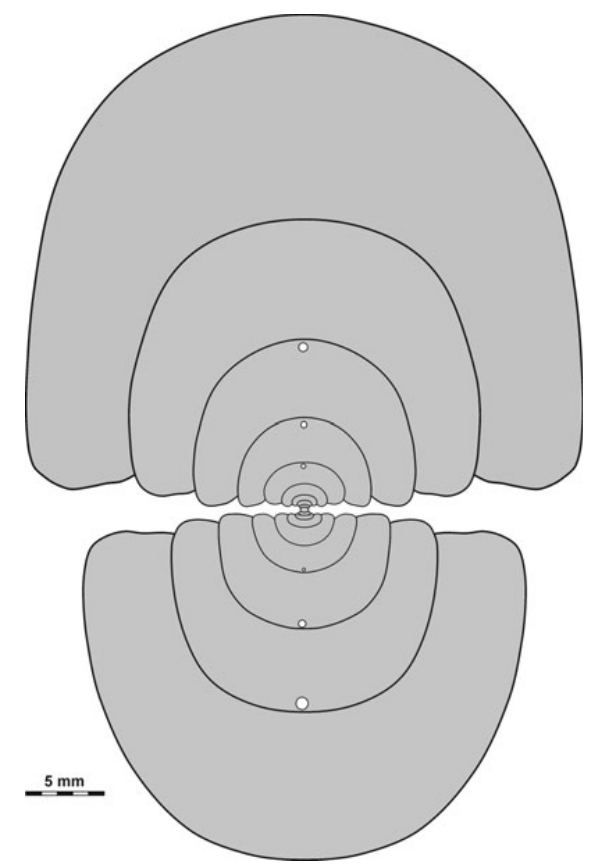

Figure 49. Goniatites deceptus sp. nov., cross section of paratype MB.C.12026.1 from bed 33 of Granite Mountain North; $\times 1.5$.
Three suture lines have been drawn of the material from Nevada and Utah, respectively, of which one (UMNH IP 3873; Fig. 48D) is from a juvenile of $8 \mathrm{~mm}$ diameter and does not show specific characters. The suture lines of UMNH IP 3874 and UMNH IP 3870 (Fig. 48E, F) are from approximately $15 \mathrm{~mm}$ diameter and differ slightly from each other. The external lobe is subparallel in the first and V-shaped in the second, slightly larger specimen. Both have a narrow, subangular ventrolateral saddle and a wider, asymmetric adventive lobe with sinuous flanks. In UMNH IP 3870, the external lobe has a width of 0.55 of its depth, and the median saddle reaches 40 per cent of the external lobe depth.

The suture lines of the material from Duckwater were obtained from diameters between 19 and $37 \mathrm{~mm}$ and show similar outlines. The suture line of paratype UMNH IP 3849 (Fig. 50G) has, at $37 \mathrm{~mm}$ conch diameter, a V-shaped external lobe, in which the flanks are almost straight and diverge slowly. The median saddle is raised to a height of 0.45 of the $E$ lobe depth. The ventrolateral saddle is rather narrow and asymmetric; it is subacute at its top and appears to be dorsally inclined. The adventive lobe is as wide as the external lobe and has strongly curved flanks. 
Dieter Korn \& Alan L. Titus • Goniatites Zone (middle Mississippian) ammonoids, Nevada and Utah
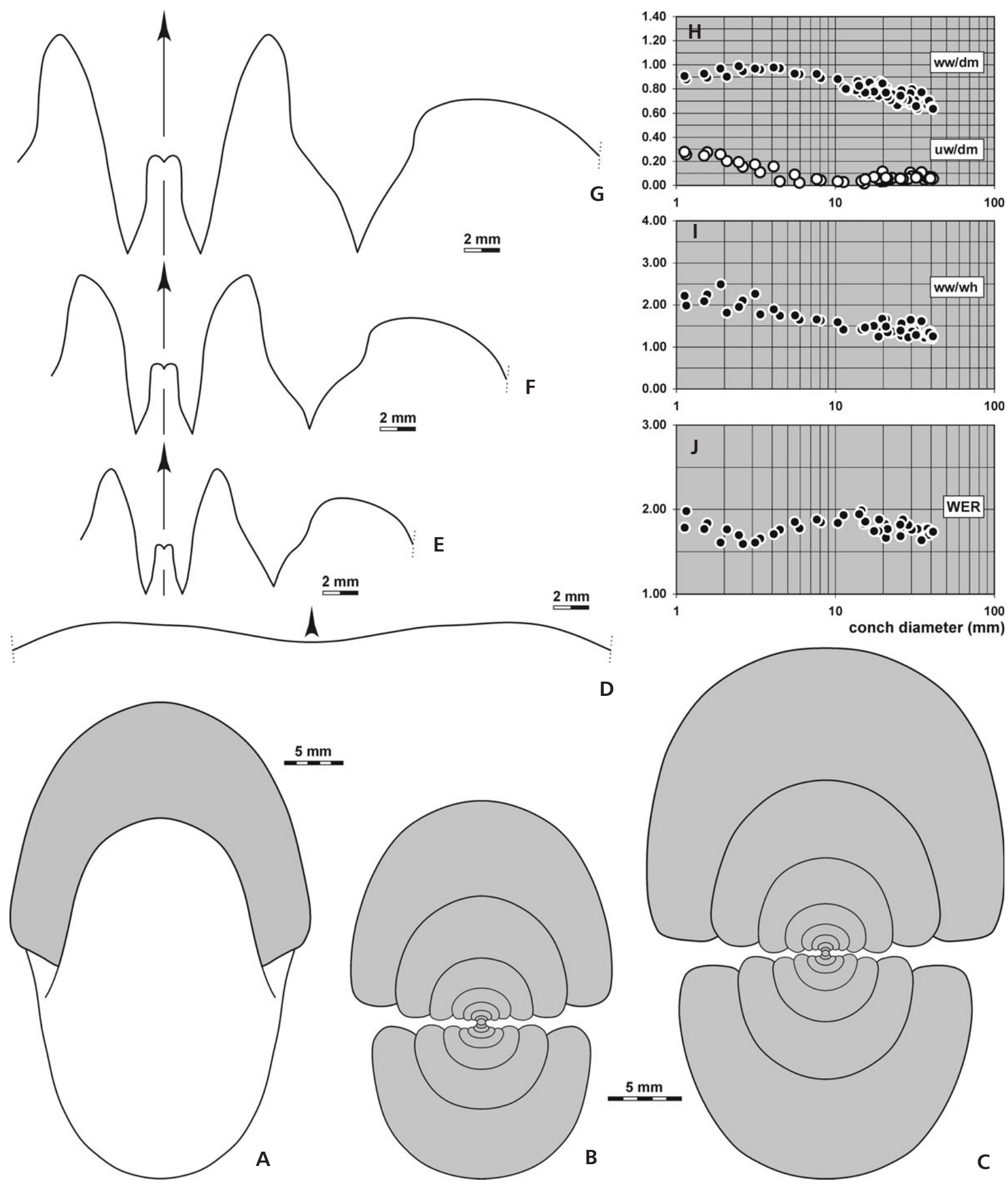

D

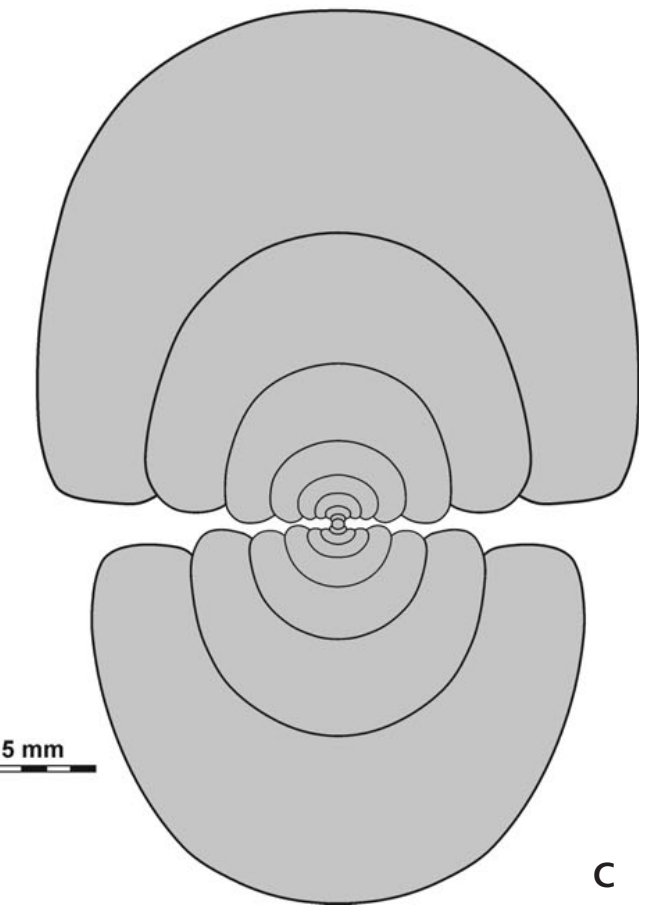

Figure 50. Goniatites deceptus sp. nov. from localities in Nevada. $\bullet$ A - dorsal view of paratype MB.C.12027.2 from Cathedral Canyon; $\times 2$ 2.0. $\bullet$ B - cross section of paratype MB.C.12028.1 from bed 4 of Duckwater Hills; $\times 2.5 . \bullet$ - cross section of paratype MB.C.12028. 2 from bed 4 of Duckwater Hills; $\times 2.5$. - D - growth line course of paratype MB.C.12027.3 from Cathedral Canyon, at $24.8 \mathrm{~mm}$ diameter, $20.3 \mathrm{~mm}$ ww, $13.2 \mathrm{~mm}$ wh; $\times 3.0$. $\bullet \mathrm{E}-$ suture line of paratype UMNH IP 3848 from bed 4 (sample 93NVNY-1) of Duckwater Hills, at $19.0 \mathrm{~mm}$ diameter, $14.3 \mathrm{~mm}$ ww, $9.8 \mathrm{~mm}$ wh; $\times 5.0$. $\bullet \mathrm{F}-$ suture line of paratype UMNH IP 3846 from bed 4 (sample 93NVNY-1) of Duckwater Hills, at $28.1 \mathrm{~mm}$ diameter, $20.6 \mathrm{~mm}$ ww, $14.4 \mathrm{~mm}$ wh; $\times 5.0$. $\bullet \mathrm{G}-$ suture line of paratype UMNH IP 3849 from bed 4 (sample 93NVNY-1) of Duckwater Hills, at $36.8 \mathrm{~mm}$ diameter, $27.6 \mathrm{~mm}$ ww, $19.5 \mathrm{~mm}$ wh; $\times 5.0 \cdot \bullet \mathrm{H}-\mathrm{J}-$ ontogenetic development of the conch width index (ww/dm), umbilical width index (uw/dm), and whorl expansion rate (WER) of all available specimens. 
Table 26. Conch ontogeny (Figs 48, 50) of Goniatites deceptus sp. nov.

\begin{tabular}{|c|c|c|c|}
\hline $\mathrm{dm}$ & conch shape & whorl cross section shape & aperture \\
\hline $1.5 \mathrm{~mm}$ & $\begin{array}{l}\text { globular; subinvolute or subevolute } \\
(\mathrm{ww} / \mathrm{dm}=0.85-1.00 ; \mathrm{uw} / \mathrm{dm}=0.25-0.35)\end{array}$ & $\begin{array}{l}\text { strongly depressed; strongly embracing } \\
(\mathrm{ww} / \mathrm{wh}=2.10-2.50 ; \mathrm{IZR}=0.35-045)\end{array}$ & low or moderate $($ WER $=1.60-1.80)$ \\
\hline $5 \mathrm{~mm}$ & $\begin{array}{l}\text { globular; involute } \\
(\mathrm{ww} / \mathrm{dm}=0.90-1.00 ; \mathrm{uw} / \mathrm{dm}=0.03-0.10)\end{array}$ & $\begin{array}{l}\text { moderately depressed; very strongly embracing } \\
(\mathrm{ww} / \mathrm{wh}=1.60-1.90 ; \mathrm{IZR}=0.50-0.60)\end{array}$ & moderate $(\mathrm{WER}=1.75-1.95)$ \\
\hline $10 \mathrm{~mm}$ & $\begin{array}{l}\text { thickly pachyconic or globular; involute } \\
(\mathrm{ww} / \mathrm{dm}=0.75-0.95 ; \mathrm{uw} / \mathrm{dm}=0.00-0.08)\end{array}$ & $\begin{array}{l}\text { weakly to mod. depressed; very strongly embracing } \\
(\mathrm{ww} / \mathrm{wh}=1.40-1.80 ; \mathrm{IZR}=0.50-0.60)\end{array}$ & low or moderate $($ WER $=1.60-1.95)$ \\
\hline $25 \mathrm{~mm}$ & $\begin{array}{l}\text { thinly or thickly pachyconic; involute } \\
(\mathrm{ww} / \mathrm{dm}=0.65-0.75 ; \mathrm{uw} / \mathrm{dm}=0.00-0.08)\end{array}$ & $\begin{array}{l}\text { weakly or mod. depressed; very strongly embracing } \\
(\mathrm{ww} / \mathrm{wh}=1.20-1.60 ; \mathrm{IZR}=0.50-0.60)\end{array}$ & low or moderate $($ WER $=1.65-1.95)$ \\
\hline $55 \mathrm{~mm}$ & $\begin{array}{l}\text { thinly pachyconic; involute } \\
(\mathrm{ww} / \mathrm{dm}=0.60-0.65 ; \mathrm{uw} / \mathrm{dm}=0.05-0.10)\end{array}$ & $\begin{array}{l}\text { weakly depressed; very strongly embracing } \\
(\mathrm{ww} / \mathrm{wh}=1.10-1.20 ; \mathrm{IZR}=0.50-0.60)\end{array}$ & low $($ WER $=1.65-1.75)$ \\
\hline
\end{tabular}

Table 27. Conch dimensions (in $\mathrm{mm}$ ) and proportions for reference specimens of Goniatites deceptus sp. nov. from localities in Utah.

\begin{tabular}{|c|c|c|c|c|c|c|c|c|c|c|}
\hline & $\mathrm{dm}$ & ww & wh & uw & ah & ww/dm & ww/wh & $\mathrm{uw} / \mathrm{dm}$ & WER & IZR \\
\hline PT UMNH IP 3939 & 60.9 & 36.4 & 30.8 & 4.7 & 14.0 & 0.60 & 1.18 & 0.08 & 1.69 & 0.55 \\
\hline PT UMNH IP 3945 & 54.9 & 32.2 & 28.4 & 3.7 & 13.3 & 0.59 & 1.13 & 0.07 & 1.74 & 0.53 \\
\hline PT UMNH IP 3933 & 48.8 & 36.0 & 25.4 & 4.8 & 12.4 & 0.74 & 1.42 & 0.10 & 1.80 & 0.51 \\
\hline HT UMNH IP 3937 & 40.3 & 27.3 & 20.8 & 2.5 & 10.0 & 0.68 & 1.31 & 0.06 & 1.77 & 0.52 \\
\hline PT UMNH IP 3934 & 39.1 & 24.8 & 21.4 & 3.0 & 9.9 & 0.63 & 1.16 & 0.08 & 1.79 & 0.54 \\
\hline PT UMNH IP 3946 & 37.7 & 25.3 & 19.4 & 2.5 & 8.9 & 0.67 & 1.30 & 0.07 & 1.72 & 0.54 \\
\hline PT UMNH IP 3868 & 25.8 & 17.3 & 14.2 & 1.0 & 7.2 & 0.67 & 1.22 & 0.04 & 1.92 & 0.49 \\
\hline PT MB.C. 12026.2 & 25.4 & 20.1 & 12.6 & 1.9 & 5.7 & 0.79 & 1.59 & 0.07 & 1.66 & 0.55 \\
\hline PT UMNH IP 3938 & 24.0 & 17.0 & 12.6 & 1.4 & 5.8 & 0.71 & 1.35 & 0.06 & 1.74 & 0.54 \\
\hline PT UMNH IP 3869 & 22.4 & 15.5 & 11.7 & 1.0 & 5.7 & 0.69 & 1.32 & 0.05 & 1.79 & 0.51 \\
\hline PT UMNH IP 3870 & 19.5 & 14.6 & 10.4 & 0.9 & 5.4 & 0.75 & 1.40 & 0.05 & 1.91 & 0.48 \\
\hline
\end{tabular}

Table 28. Conch dimensions (in $\mathrm{mm}$ ) and proportions for reference specimens of Goniatites deceptus sp. nov. from localities in Nevada.

\begin{tabular}{|c|c|c|c|c|c|c|c|c|c|c|}
\hline & $\mathrm{dm}$ & ww & wh & uw & $\mathrm{ah}$ & ww/dm & ww/wh & uw/dm & WER & IZR \\
\hline PT MB.C.12027.2 & 41.0 & 26.1 & 20.8 & 2.3 & 9.9 & 0.64 & 1.25 & 0.06 & 1.74 & 0.52 \\
\hline PT UMNH IP 3845 & 40.5 & 26.3 & 21.9 & 2.7 & 9.8 & 0.65 & 1.20 & 0.07 & 1.74 & 0.55 \\
\hline PT UMNH IP 4020 & 37.3 & 23.7 & 20.2 & 2.8 & - & 0.64 & 1.17 & 0.08 & - & - \\
\hline PT UMNH IP 3846 & 30.3 & 20.5 & 15.0 & 2.3 & 7.5 & 0.68 & 1.37 & 0.08 & 1.76 & 0.50 \\
\hline PT MB.C.12027.1 & 25.7 & 19.2 & 13.8 & 1.4 & 5.9 & 0.75 & 1.39 & 0.05 & 1.68 & 0.57 \\
\hline PT UMNH IP 3847 & 20.8 & 16.3 & 9.8 & 1.0 & 4.7 & 0.78 & 1.67 & 0.05 & 1.66 & 0.52 \\
\hline
\end{tabular}

Table 29. Suture line proportions (Figs 48, 50) for Goniatites deceptus sp. nov.

\begin{tabular}{lccccccc}
\hline specimen & at dm & EL w/d & EL/VLS & EL/AL & MS h & VLS w/h & remarks \\
\hline UMNH IP 3849 & 36.8 & 0.55 & 1.64 & 1.03 & 0.45 & 0.33 & E lobe V-shaped \\
UMNH IP 3846 & 28.1 & 0.49 & 1.24 & 0.81 & 0.44 & 0.40 & VL saddle asymmetric \\
UMNH IP 3848 & 19.0 & 0.47 & 1.20 & 0.91 & 0.39 & 0.39 & VL saddle almost symmetric \\
UMNH IP 3870 & 15.0 & 0.58 & 1.29 & 0.86 & 0.40 & 0.45 & E lobe V-shaped \\
UMNH IP 3874 & 14.0 & 0.54 & 1.37 & 0.77 & 0.39 & 0.40 & E lobe slightly Y-shaped \\
\hline
\end{tabular}

Discussion. - Specimens of G. deceptus sp. nov. have previously been attributed to G. multiliratus Gordon, 1962, a species described from the Caney Shale of Oklahoma but also occurring in Texas and Arkansas (Gordon 1965). Both species do possess similar shell ornament with numerous delicate spiral lines, but differ in their conch ontogeny and suture line. G. deceptus has a narrower external lobe (width/height ratio $=0.50-0.55$ in $G$. deceptus but 0.65 in G. multiliratus at $25 \mathrm{~mm}$ conch diameter) and a narrower umbilicus in the juvenile stage. There is also clear strati- 
graphic separation of G. deceptus and G. multiliratus, with the former occurring immediately below G. eganensis n. sp., and the latter above. Furthermore, the older species G. deceptus does not appear to have ever been collected from east of the Great Basin region.

G. eganensis sp. nov. is very similar in conch shape and suture line, but lacks spiral ornament.

\section{Goniatites eganensis sp. nov.}

Figures 51-54

1897 Glyphioceras incisum Hyatt; Smith, p. 111, pls XIII-XV.

1903 Goniatites crenistria Phillips; Smith, p. 68 (part), pl. XIV, figs $1-12$, pl. XV, figs $1-8$, pl. XVI, figs $1 \mathrm{a}-\mathrm{j}$, pl. XXVI, figs $1-3$ (not 4, 5).

1911 Goniatites crenistria Phillips; Girty, p. 99, pl. XV, figs $8,9$.

1949 Goniatites choctawensis Shumard; Miller et al., p. 608 , pl. 99 , figs 7,8 .

1965 Goniatites aff. G. crenistria Phillips; Gordon (part), p. 187 , pl. 18 , figs $1-6,46$ A-C.

1965 Goniatites crenistria Phillips; King, p. 42.
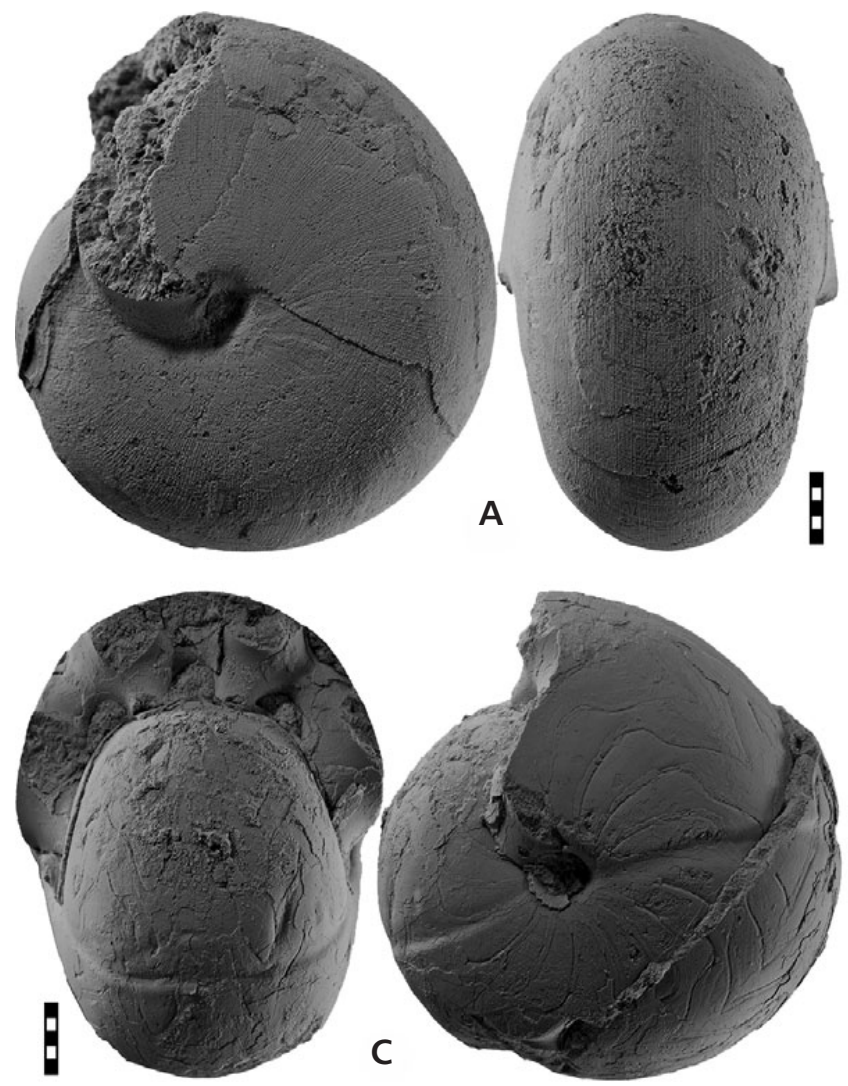

Figure 51. Goniatites eganensis sp. nov. from localities in Nevada. • A - paratype UMNH IP 4020 from bed 6 (sample 93NVLI-3) of Trough Springs Canyon; $\times 1.5$. $\bullet$ B - holotype UMNH IP 4021 from bed 6 (sample 93NVLI-3) of Trough Springs Canyon; $\times 1.5$. $\bullet$ C - paratype UMNH IP 4010 from bed 44 (sample 07NVWP-3) of Hamilton Canyon; × 1.5. • D - paratype MB.C.12030.1 from bed 44 of Hamilton Canyon; $\times 2.5$.
1970 Goniatites americanus Gordon; Gordon, p. 818 (referring to Arkansas material only), text-fig. 2 (Ozark Plateau portion only).

1972 Goniatites crenistria Phillips; Drahovzal, p. 20 (part), figs 3 , 4, pl. I, figs $2-4$.

Derivation of name. - After the Egan Range, where the type locality is.

Holotype. - Specimen UMNH IP 4021, illustrated in Fig. 51B.

Type locality and horizon. - Trough Springs Canyon, bed 6 (sample 93NVLI-3); Camp Canyon Member of Chainman Formation, Goniatites eganensis Biozone.

Material. - 76 specimens; conch diameter up to $40 \mathrm{~mm}$.

Diagnosis. - Goniatites with a globular conch between 2 and $8 \mathrm{~mm}$ diameter $(\mathrm{ww} / \mathrm{dm}=0.85-0.90)$ and thickly pachyconic conch $(\mathrm{ww} / \mathrm{dm}=0.75-0.80)$ at $20 \mathrm{~mm}$ diameter. Umbilicus moderate in early ontogeny (uw/dm = $0.20-0.30$ at $2 \mathrm{~mm}$ diameter) and very narrow in all stages larger than $4 \mathrm{~mm}$ diameter $(\mathrm{uw} / \mathrm{dm}=0.02-0.10)$. Umbilical wall convexly rounded in all stages. Aperture low or
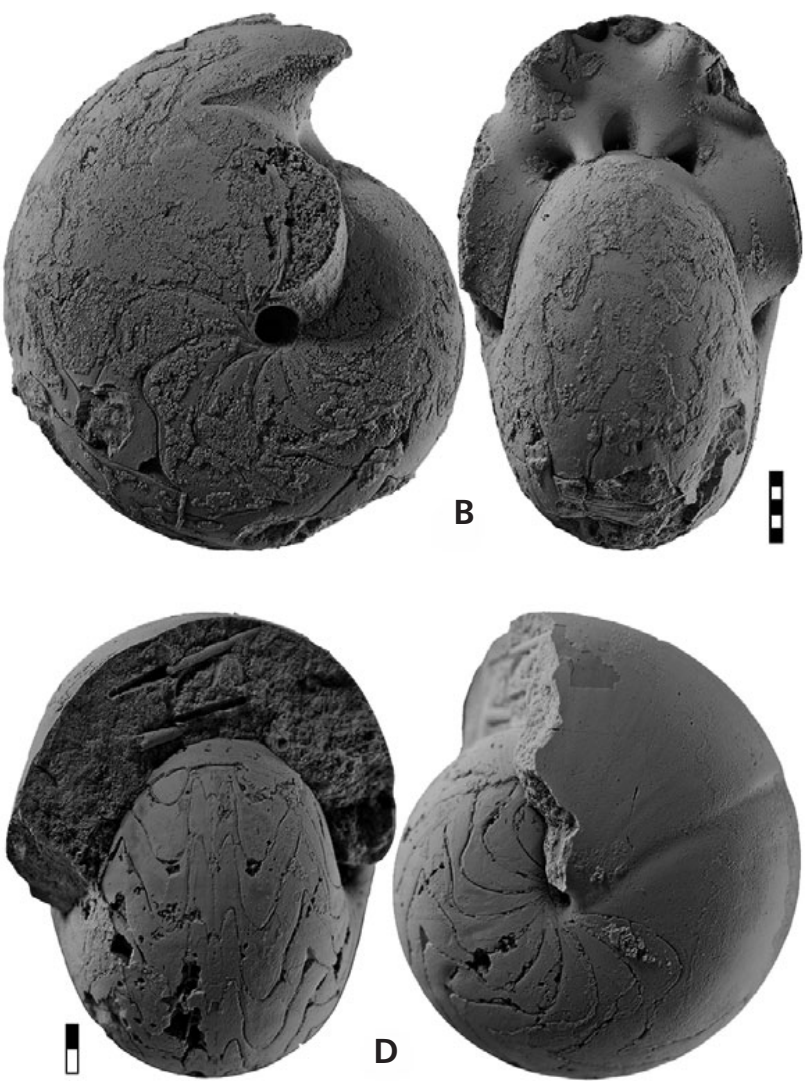

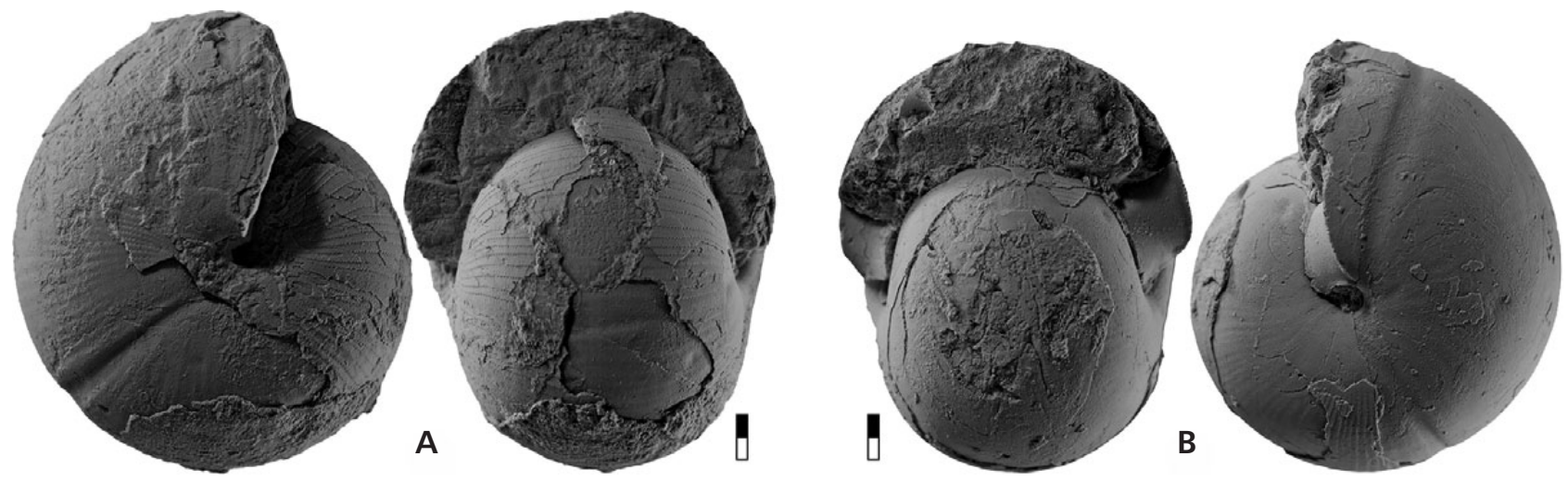

Figure 52. Goniatites eganensis sp. nov. from bed 25 (sample 01UTMI-5) of South Burbank Hills (Utah). • A - paratype UMNH IP $4003 ; \times 2.5$. $\cdot$ B - paratype UMNH IP $4004 ; \times 2.5$.
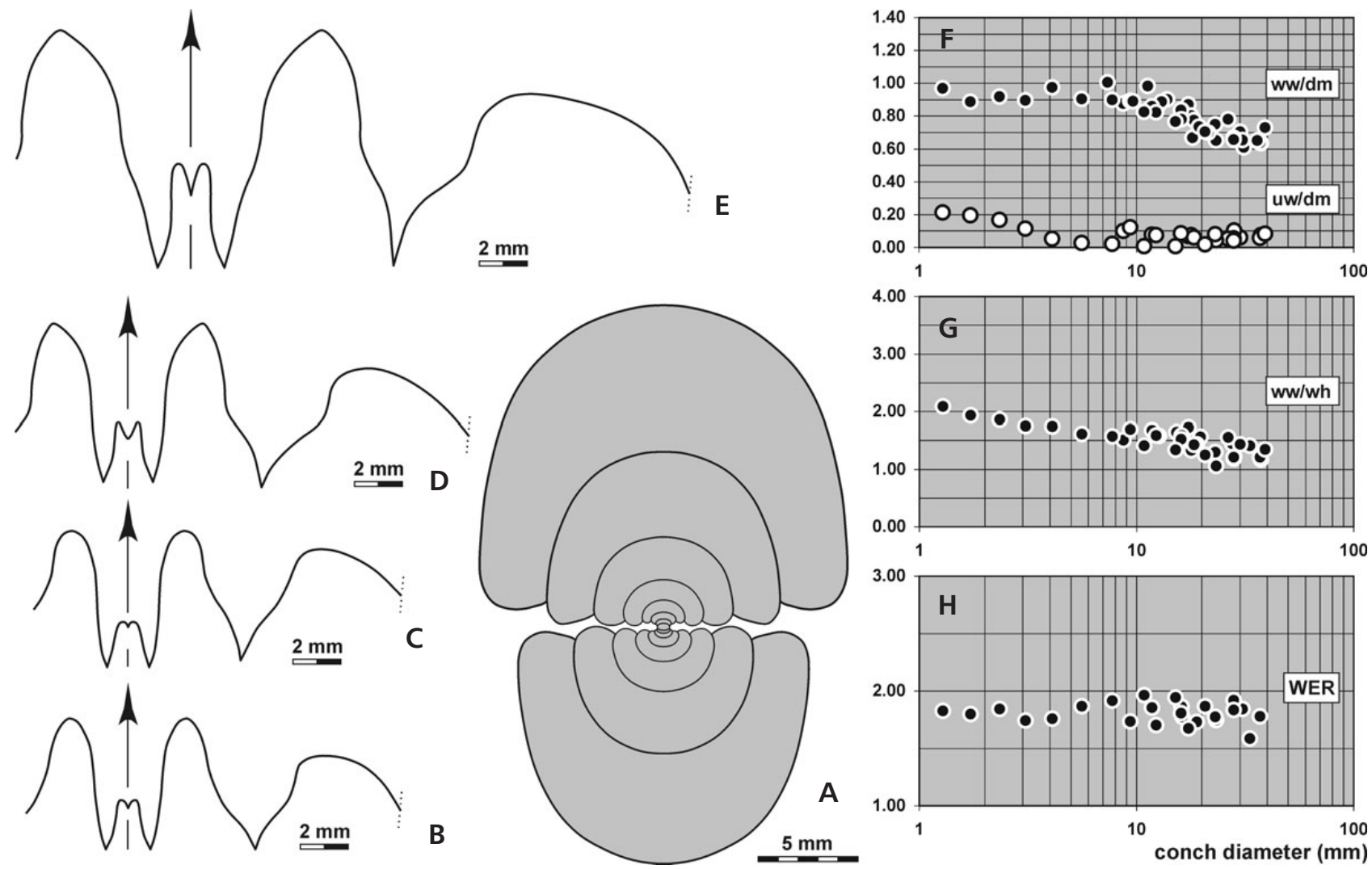

Figure 53. Goniatites eganensis sp. nov. from localities in Nevada. • A - cross section of specimen UMNH IP 4022 from bed 6 (sample 93NVLI-3) of Trough Springs Canyon; $\times 2.5 . \bullet B-$ suture line of paratype MB.C.12030.2 from bed 44 of Hamilton Canyon, at $15.3 \mathrm{~mm}$ diameter, $12.2 \mathrm{~mm}$ ww, $7.3 \mathrm{~mm}$ wh; $\times 3.0$. $\bullet$ C - suture line of paratype MB.C.12030.1 from bed 44 of Hamilton Canyon, at $15.7 \mathrm{~mm}$ diameter, $13.0 \mathrm{~mm}$ ww, $7.5 \mathrm{~mm}$ wh; $\times 3.0 . \bullet \mathrm{D}-\mathrm{su}-$ ture line of paratype MB.C.12030.3 from bed 44 of Hamilton Canyon, at $20.1 \mathrm{~mm}$ diameter, $16.0 \mathrm{~mm}$ ww, $10.4 \mathrm{~mm}$ wh; $\times 3.0$. $\bullet$ E - suture line of paratype UMNH IP 4010 from bed 6 (sample 93NVLI-3) of Trough Springs Canyon, at $24.6 \mathrm{~mm}$ ww, $14.3 \mathrm{~mm}$ wh; $\times 3.0$. $\bullet \mathrm{F}-\mathrm{H}-$ ontogenetic development of the conch width index (ww/dm), umbilical width index (uw/dm), and whorl expansion rate (WER) of all available specimens.

moderately high $($ WER $=1.70-1.80$ at $20 \mathrm{~mm}$ diameter $)$. Ornament with crenulated, slightly biconvex and rectiradiate growth-lines; external sinus shallow. Suture line at $25 \mathrm{~mm}$ conch diameter with narrow external lobe $(0.55$ of the external lobe depth; 1.25 of the ventrolateral saddle width), and moderately low median saddle ( 0.40 of the ex- ternal lobe depth). External lobe V-shaped with narrow, V-shaped prongs; ventrolateral saddle subangular.

Description. - The species shows ontogenetic changes typical for the genus (Figs 48G-I, 50F-H). The early juvenile stage has an open umbilicus, but this is closed rapidly and 

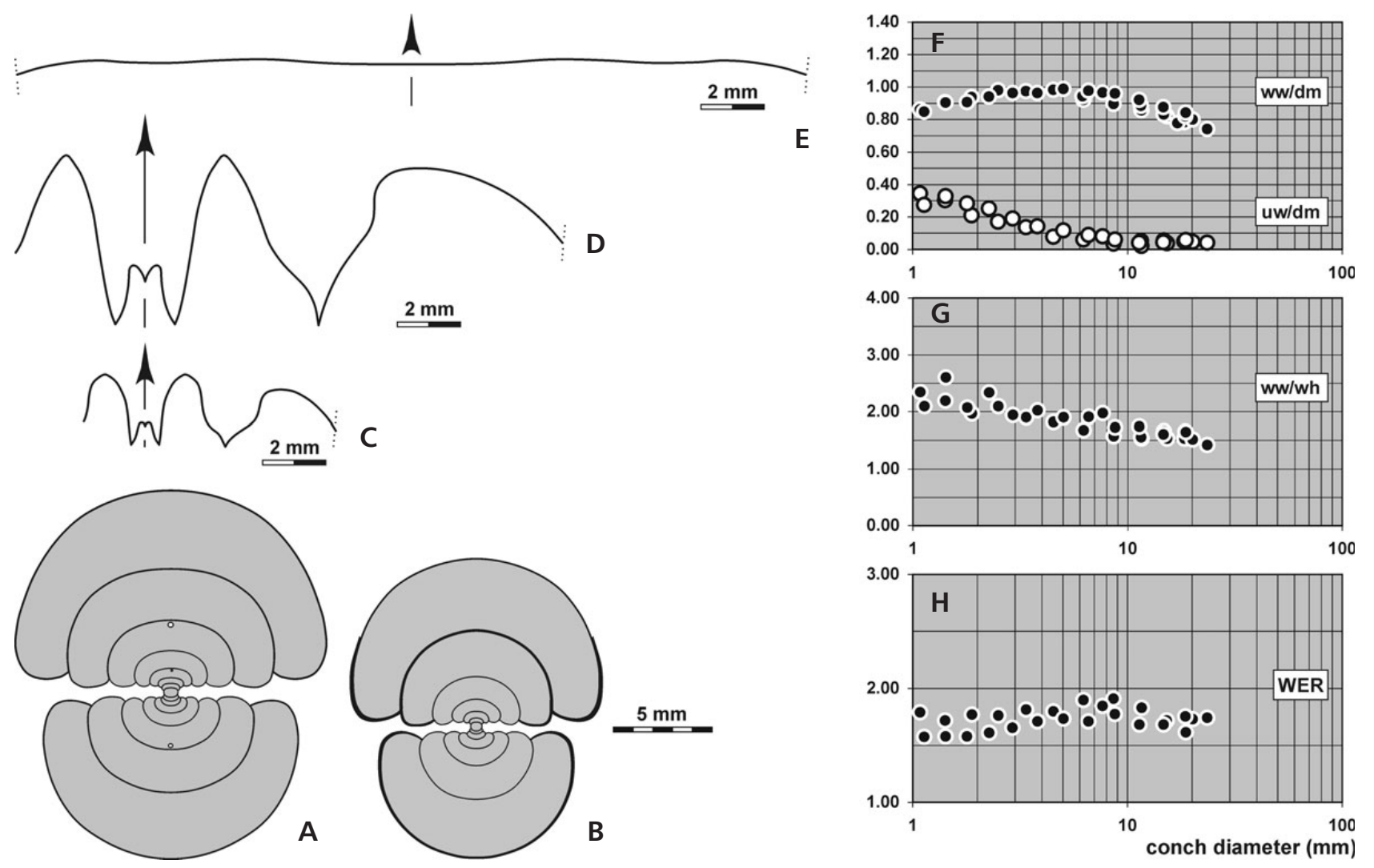

Figure 54. Goniatites eganensis sp. nov. from bed 25 (sample 07UTMI-1) of South Burbank Hills (Utah). • A - cross section of paratype UMNH IP $3997 ; \times 2.5$. $\bullet$ B cross section of paratype UMNH IP $4005 ; \times 2.5$. $\bullet$ - suture line of paratype UMNH IP 4006 , at $7.2 \mathrm{~mm}$ diameter, $7.3 \mathrm{~mm}$ ww, $3.8 \mathrm{~mm}$ wh; $\times$ 4.0. $\bullet$ D - suture line of paratype UMNH IP 4004, at $17.3 \mathrm{~mm}$ diameter, $14.4 \mathrm{~mm}$ ww, $9.2 \mathrm{~mm}$ wh; $\times 4.0$. $\bullet$ E - growth line course of paratype UMNH IP 4004, at $14.8 \mathrm{~mm}$ diameter, $12.9 \mathrm{~mm} \mathrm{ww}, 9.0 \mathrm{~mm}$ wh; $\times 4.0 . \bullet \mathrm{F}-\mathrm{H}$ - ontogenetic development of the conch width index (ww/dm), umbilical width index (uw/dm), and whorl expansion rate (WER) of all available specimens.

already above $4 \mathrm{~mm}$ diameter, the uw/dm ratio is lower than 0.10 . There is a juvenile ontogenetic trend towards a thicker conch, with a maximum ww/dm ratio of $0.90-1.00$ between 2 and $8 \mathrm{~mm}$ diameter. Thereafter, the conch becomes more slender and the ww/dm ratio amounts to 0.74 at $24 \mathrm{~mm}$ diameter. The aperture has a constant opening rate throughout ontogeny; limited fluctuations occur between 1.70 and 1.90 .

The largest sectioned paratype UMNH IP 4022 (Fig. 53A) from Trough Springs Canyon has a maximum conch diameter of $28 \mathrm{~mm}$ has a globular conch shape up to about $8 \mathrm{~mm} \mathrm{dm}$. Thereafter, the conch becomes continuously more slender, being thinly pachyconic at $28 \mathrm{~mm} \mathrm{dm}$ $(\mathrm{ww} / \mathrm{dm}=0.66)$.

A sectioned paratype, UMNH IP 4005 (Fig. 54B), from South Burbank Hills has a maximum diameter of $15 \mathrm{~mm}$ and displays six whorls. It is a section of a ball-shaped conch in which all whorls show a similar section. The umbilical wall, flanks, and venter are broadly rounded, and the umbilical opening is similar throughout ontogeny.

Holotype UMNH IP 4021 (Fig. 51B) from Trough Springs has a conch diameter of $37 \mathrm{~mm}$ and is fully septate with small portions of shell preserved. It is thinly pachyconic and involute $(\mathrm{ww} / \mathrm{dm}=0.64 ; \mathrm{uw} / \mathrm{dm}=0.06)$ with strongly converging flanks and a broadly rounded venter. The aperture is moderately high $(\mathrm{WER}=1.78)$. The shell surface displays strongly crenulated growth lines, which have a shallow lateral sinus, a low ventrolateral projection, and a shallow ventral sinus.

The largest available specimen from South Burbank Hills (paratype UMNH IP 4007) is $23.5 \mathrm{~mm}$ in diameter and is thickly pachyconic ( $\mathrm{ww} / \mathrm{dm}=0.74$ ). The umbilicus is closed and the aperture is narrow $(\mathrm{WER}=1.74)$. It is partly testiferous and shows growth lines that run concavo-convex across the flanks and venter and form a moderately deep ventral sinus. These growth lines are intensely crenulated and rather coarse with a spacing of about $0.5 \mathrm{~mm}$.

Smaller specimens, such as paratypes UMNH IP 4003 and UMNH IP 4004 (20, resp. 18 mm diameter; Fig. 52A, B), have a similar but somewhat more globular form $(\mathrm{ww} / \mathrm{dm}=$ 0.80-0.82) and display an ornament with coarser growth lines having an almost straight course across the flanks and venter. These specimens also show irregularly arranged constrictions on the internal mould. 
Table 30. Conch ontogeny (Figs 53, 54) of Goniatites eganensis sp. nov.

\begin{tabular}{|c|c|c|c|}
\hline $\mathrm{dm}$ & conch shape & whorl cross section shape & aperture \\
\hline $1.5 \mathrm{~mm}$ & $\begin{array}{l}\text { globular; subinvolute or subevolute } \\
(\mathrm{ww} / \mathrm{dm}=0.85-0.95 ; \mathrm{uw} / \mathrm{dm}=0.25-0.35)\end{array}$ & $\begin{array}{l}\text { strongly depressed; strongly embracing } \\
(\mathrm{ww} / \mathrm{wh}=2.00-2.50 ; \mathrm{IZR}=0.40-045)\end{array}$ & low or moderate $($ WER $=1.60-1.80)$ \\
\hline $5 \mathrm{~mm}$ & $\begin{array}{l}\text { globular; involute } \\
(\mathrm{ww} / \mathrm{dm}=0.90-1.00 ; \mathrm{uw} / \mathrm{dm}=0.03-0.10)\end{array}$ & $\begin{array}{l}\text { moderately depressed; very strongly embracing } \\
(\mathrm{ww} / \mathrm{wh}=1.60-1.90 ; \mathrm{IZR}=0.50-0.60)\end{array}$ & low or moderate $(\mathrm{WER}=1.70-1.90)$ \\
\hline $10 \mathrm{~mm}$ & $\begin{array}{l}\text { thickly pachyconic or globular; involute } \\
(\mathrm{ww} / \mathrm{dm}=0.85-0.95 ; \mathrm{uw} / \mathrm{dm}=0.00-0.08)\end{array}$ & $\begin{array}{l}\text { weakly to mod. depressed; very strongly embracing } \\
(\mathrm{ww} / \mathrm{wh}=1.40-1.80 ; \mathrm{IZR}=0.50-0.60)\end{array}$ & moderate $(\mathrm{WER}=1.75-2.00)$ \\
\hline $25 \mathrm{~mm}$ & $\begin{array}{l}\text { thinly or thickly pachyconic; involute } \\
(\mathrm{ww} / \mathrm{dm}=0.65-0.80 ; \mathrm{uw} / \mathrm{dm}=0.00-0.08)\end{array}$ & $\begin{array}{l}\text { weakly or mod. depressed; very strongly embracing } \\
(\mathrm{ww} / \mathrm{wh}=1.10-1.55 ; \mathrm{IZR}=0.50-0.60)\end{array}$ & moderate $($ WER $=1.75-2.00)$ \\
\hline $40 \mathrm{~mm}$ & $\begin{array}{l}\text { thinly or thickly pachyconic; involute } \\
(\mathrm{ww} / \mathrm{dm}=0.65-0.75 ; \mathrm{uw} / \mathrm{dm}=0.05-0.10)\end{array}$ & $\begin{array}{l}\text { weakly depressed; very strongly embracing } \\
(\mathrm{ww} / \mathrm{wh}=1.20-1.40 ; \mathrm{IZR}=0.50-0.60)\end{array}$ & moderate $(\mathrm{WER} \sim 1.80)$ \\
\hline
\end{tabular}

Table 31. Conch dimensions (in mm) and proportions for reference specimens of Goniatites eganensis sp. nov. from localities in Nevada.

\begin{tabular}{|c|c|c|c|c|c|c|c|c|c|c|}
\hline & $\mathrm{dm}$ & ww & wh & uw & $\mathrm{ah}$ & $\mathrm{ww} / \mathrm{dm}$ & ww/wh & uw/dm & WER & IZR \\
\hline PT UMNH IP 4010 & 39.0 & 28.5 & 21.2 & 3.3 & - & 0.73 & 1.35 & 0.08 & - & - \\
\hline PT UMNH IP 4020 & 37.3 & 23.7 & 20.2 & 2.8 & - & 0.64 & 1.17 & 0.08 & - & - \\
\hline HT UMNH IP 4021 & 37.0 & 23.6 & 19.5 & 2.2 & 9.3 & 0.64 & 1.21 & 0.06 & 1.78 & 0.52 \\
\hline PT MB.C.12030.1 & 19.0 & 15.4 & 10.7 & 1.1 & 4.5 & 0.81 & 1.44 & 0.06 & 1.73 & 0.58 \\
\hline PT MB.C.12030.2 & 16.3 & 13.0 & 8.3 & 0.9 & 4.1 & 0.80 & 1.57 & 0.06 & 1.78 & 0.51 \\
\hline
\end{tabular}

Table 32. Conch dimensions (in $\mathrm{mm}$ ) and proportions for reference specimens of Goniatites eganensis sp. nov. from localities in Utah.

\begin{tabular}{lrrrrrrrrrr}
\hline & dm & ww & wh & uw & ah & ww/dm & ww/wh & uw/dm & WER & IZR \\
\hline PT UMNH IP 4003 & 20.1 & 16.1 & 10.6 & 1.0 & 4.8 & 0.80 & 1.52 & 0.05 & 1.73 & 0.55 \\
PT UMNH IP 4004 & 18.5 & 15.2 & 9.2 & 1.0 & 4.6 & 0.82 & 1.65 & 0.05 & 1.76 & 0.51 \\
PT UMNH IP 4006 & 7.7 & 7.4 & 3.8 & 0.6 & 2.0 & 0.97 & 1.98 & 0.08 & 1.84 & 0.46 \\
\hline
\end{tabular}

Table 33. Suture line proportions (Figs 53, 54) for Goniatites eganensis sp. nov.

\begin{tabular}{llllllll}
\hline specimen & at dm & EL w/d & EL/VLS & EL/AL & MS h & VLS w/h & remarks \\
\hline UMNH IP 4010 & 34.0 & 0.57 & 1.32 & 1.22 & 0.44 & 0.43 & VL saddle tectiform, flanks sinuous \\
MB.C.12030.3 & 20.1 & 0.47 & 1.24 & 0.72 & 0.38 & 0.38 & VL saddle acute \\
UMNH IP 4004 & 17.3 & 0.57 & 1.29 & 1.01 & 0.35 & 0.44 & VL saddle acute \\
MB.C.12030.1 & 15.7 & 0.46 & 1.11 & 0.93 & 0.33 & 0.41 & VL saddle subacute \\
MB.C.12030.2 & 15.3 & 0.52 & 1.29 & 0.85 & 0.38 & 0.40 & VL saddle subacute \\
\hline
\end{tabular}

Paratype UMNH IP 4010 shows the adult suture line, which possesses a V-shaped external lobe with sinuous flanks and a median saddle that is lower than half the depth of the E lobe. The ventrolateral saddle is almost symmetric with a tectiform and subacute top; the adventive lobe is asymmetric with both flanks curved (Fig. 53E).

The suture line of paratype UMNH IP 4004 (Fig. 54D) has, at $17 \mathrm{~mm}$ diameter, a V-shaped external lobe with almost non-curved flanks. Width/depth ratios of the external lobe are: 0.35 at the base, 0.56 at half depth, and 0.93 at the top. The ventrolateral saddle is slightly asymmetric and has a subacute top. The adventive lobe is asymmetric with a lesser curved ventral flank. The width ratio of external lobe to adventive lobe is 1.00 .
Discussion. - Goniatites eganensis sp. nov. is, in conch shape, conch ontogeny, conch variability, and suture line, very similar to $G$. deceptus sp. nov. The two species differ mainly in the absence of spiral ornament in G. eganensis. As discussed previously, specimens, which we refer to this species, have been frequently included in the stratigraphically older species G. crenistria and G. americanus. G. americanus and the similar G. hudsoni possess narrower external lobes; G. crenistria is clearly separated by its almost straight flanks of the sutural elements. Goniatites eganensis is regarded by us as the most widespread member of the genus in the lower 48 states region and a key element for continental scale correlation. It can be recognized in Nevada, Utah, Texas, Oklahoma, and Arkansas, and is 

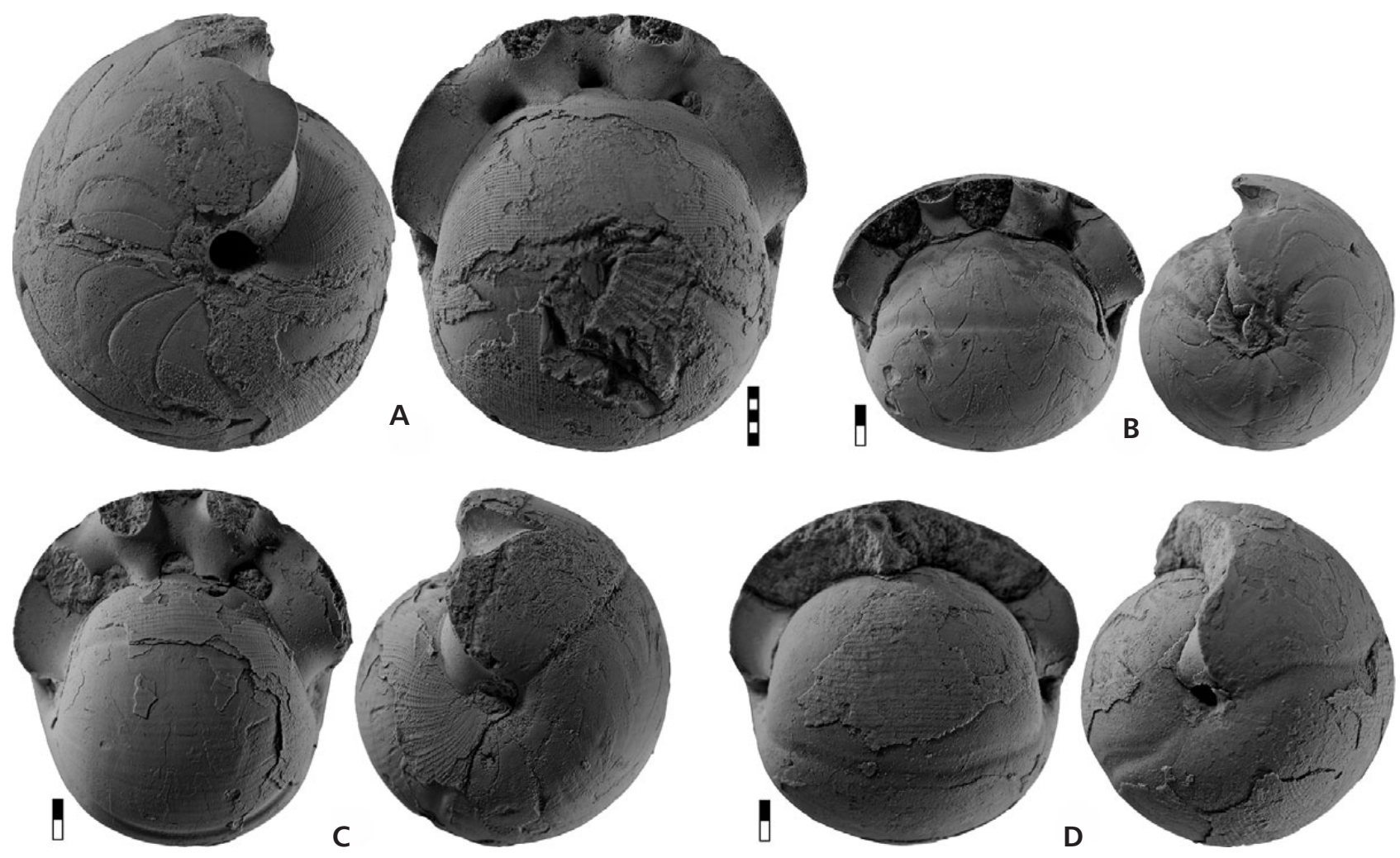

Figure 55. Goniatites sowerbyi sp. nov. $\bullet$ A - holotype UMNH IP 4065 from bed $6($ sample 93 NVLI-3) of Trough Springs Canyon; $\times 2.0$. $\bullet$ B - paratype UMNH IP 4064 from bed 16 (sample 01UTMI-49) of Conger Mountain East; $\times 2.5$. $・$ C - paratype UMNH IP 4062 from bed 28 (sample 93UTMI-27) of Jensen Wash; $\times 2.5$. $・ D$ - paratype UMNH IP 4066 from bed 6 (sample 93NVLI-3) of Trough Springs Canyon; $\times 2.5$.

the only unequivocal Brigantian species of Goniatites the eastern and western United States have in common. In the east, it is typically the oldest species found where it is associated with Girtyoceras welleri Gordon 1965.

\section{Goniatites sowerbyi sp. nov.}

Figures 55-60

Derivation of name. - After James Sowerby (1757-1822), who wrote the first valid descriptions of Carboniferous ammonoids, including Goniatites sphaericus, the type species for the genus.

Holotype. - Specimen UMNH IP 4065, illustrated in Fig. 55A.

Type locality and horizon. - Trough Springs Canyon, bed 6 (sample 93NVLI-3); Camp Canyon Member of Chainman Formation, Goniatites eganensis Biozone.

Material. - 19 specimens; conch diameter up to $54 \mathrm{~mm}$.

Diagnosis. - Goniatites with increasing conch thickness between 1 and $5 \mathrm{~mm}$ diameter (ww/dm increasing from 0,70 to $1.00-1.15)$; decreasing in later ontogeny. Conch subevolute in early ontogeny ( $\mathrm{uw} / \mathrm{dm}=0.30-0.35$ at $1-2.5 \mathrm{~mm}$ diameter) and involute in all stages larger than $8 \mathrm{~mm}$ diameter $(\mathrm{uw} / \mathrm{dm}=0.02-0.10)$. Aperture low in all stages $(\mathrm{WER}=$ 1.40-1.60). Ornament with crenulated growth-lines forming a low ventral projection. Suture line at $25 \mathrm{~mm}$ conch diameter with narrow external lobe $(0.55$ of the external lobe depth; 1.05 of the ventrolateral saddle width), and moderately low median saddle $(0.40$ of the external lobe depth). External lobe V-shaped with very narrow, $\mathrm{V}$-shaped prongs; ventrolateral saddle narrowly rounded.

Description. - The species shows some variability in the conch shape, but the ontogeny of all sectioned specimens is very similar. The initial stage (at $1 \mathrm{~mm} \mathrm{dm}$ ) is thickly pachyconic and subevolute $(\mathrm{ww} / \mathrm{dm}=0.70 ; \mathrm{uw} / \mathrm{dm}=0.35)$, and then there is a conspicuous widening of the conch towards a globular or spindle-shaped form in later ontogeny. The umbilicus is opened up to a conch diameter of $3 \mathrm{~mm}$ and thereafter becomes narrower, so that all stages larger than $8 \mathrm{~mm}$ are involute.

The four sectioned paratypes (Fig. 57A-D) closely resemble each other in their conch ontogeny, but two of them (specimens UMNH IP 4067 and UMNH IP 4068) are stouter than the specimens UMNH IP 4077 and UMNH IP 4063. 

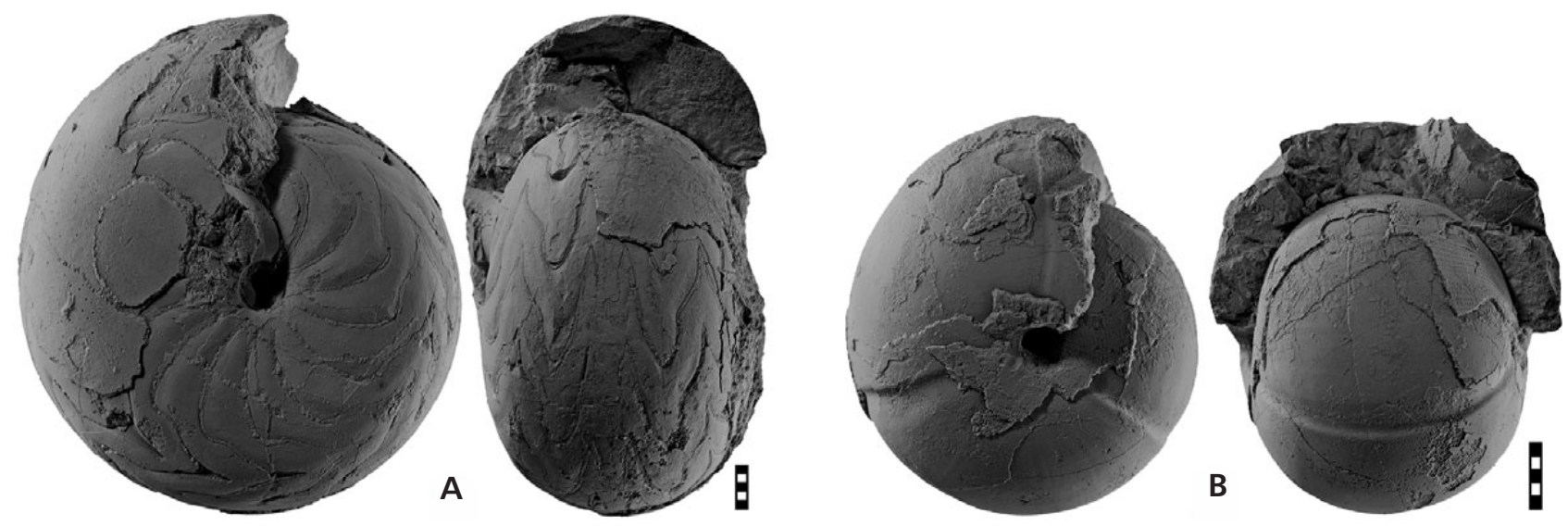

Figure 56. Goniatites sowerbyi sp. nov. from bed 44 of Hamilton Canyon. • A - paratype MB.C.12032.1; × 1.0. • B - paratype MB.C.12032.2; × 1.5.

Table 34. Conch ontogeny (Fig. 57) of Goniatites sowerbyi sp. nov.

\begin{tabular}{|c|c|c|c|}
\hline $\mathrm{dm}$ & conch shape & whorl cross section shape & aperture \\
\hline $1.5 \mathrm{~mm}$ & $\begin{array}{l}\text { thickly pachyconic; subevolute } \\
(\mathrm{ww} / \mathrm{dm}=0.75-0.85 ; \mathrm{uw} / \mathrm{dm}=0.30-0.35)\end{array}$ & $\begin{array}{l}\text { strongly depressed; strongly embracing } \\
(\mathrm{ww} / \mathrm{wh}=2.00-2.30 ; \mathrm{IZR}=0.40-0.45)\end{array}$ & low $($ WER $=1.55-1.65)$ \\
\hline $5 \mathrm{~mm}$ & $\begin{array}{l}\text { globular or spindle-shaped; involute } \\
(\mathrm{ww} / \mathrm{dm}=0.95-1.15 ; \mathrm{uw} / \mathrm{dm}=0.10-0.20)\end{array}$ & $\begin{array}{l}\text { strongly depressed; very strongly embracing } \\
(\mathrm{ww} / \mathrm{wh}=2.00-2.50 ; \mathrm{IZR}=0.50-0.65)\end{array}$ & very low or low $($ WER $=1.45-1.65)$ \\
\hline $10 \mathrm{~mm}$ & $\begin{array}{l}\text { globular or spindle-shaped; involute } \\
(\mathrm{ww} / \mathrm{dm}=0.95-1.15 ; \mathrm{uw} / \mathrm{dm}=0.05-0.10)\end{array}$ & $\begin{array}{l}\text { mod. or strongly depressed; very strongly embracing } \\
(\mathrm{ww} / \mathrm{wh}=1.80-2.30 ; \mathrm{IZR}=0.50-0.65)\end{array}$ & very low or low $($ WER $=1.45-1.65)$ \\
\hline $25 \mathrm{~mm}$ & $\begin{array}{l}\text { globular; involute } \\
(\mathrm{ww} / \mathrm{dm}=0.85-0.95 ; \mathrm{uw} / \mathrm{dm}=0.05-0.08)\end{array}$ & $\begin{array}{l}\text { moderately depressed; very strongly embracing } \\
(\mathrm{ww} / \mathrm{wh}=1.60-1.75 ; \mathrm{IZR}=0.50-0.65)\end{array}$ & very low or low $($ WER $=1.45-1.65)$ \\
\hline $50 \mathrm{~mm}$ & $\begin{array}{l}\text { globular; involute } \\
(\mathrm{ww} / \mathrm{dm}=0.85-0.95 ; \mathrm{uw} / \mathrm{dm}=0.05-0.08)\end{array}$ & $\begin{array}{l}\text { moderately depressed; very strongly embracing } \\
(\mathrm{ww} / \mathrm{wh}=1.60-1.75 ; \mathrm{IZR}=0.50-0.65)\end{array}$ & very low or low $($ WER $=1.45-1.65)$ \\
\hline
\end{tabular}

Table 35. Conch dimensions (in $\mathrm{mm}$ ) and proportions for reference specimens of Goniatites sowerbyi sp. nov.

\begin{tabular}{|c|c|c|c|c|c|c|c|c|c|c|}
\hline & $\mathrm{dm}$ & ww & wh & uw & ah & ww/dm & ww/wh & uw/dm & WER & IZR \\
\hline PT MB.C.12032.1 & 53.8 & 35.0 & 27.2 & 4.7 & 10.4 & 0.65 & 1.29 & 0.09 & 1.53 & 0.62 \\
\hline PT MB.C.12032.2 & 28.7 & 25.1 & 14.8 & 2.4 & 5.8 & 0.87 & 1.70 & 0.08 & 1.57 & 0.61 \\
\hline HT UMNH IP 4065 & 26.6 & 25.0 & 13.7 & 2.0 & 4.3 & 0.94 & 1.83 & 0.08 & 1.42 & 0.69 \\
\hline PT UMNH IP 4062 & 17.1 & 16.2 & 9.3 & 1.6 & 3.8 & 0.95 & 1.75 & 0.09 & 1.65 & 0.59 \\
\hline PT UMNH IP 4066 & 16.8 & 17.0 & 9.6 & 1.3 & 3.1 & 1.01 & 1.78 & 0.08 & 1.50 & 0.68 \\
\hline PT UMNH IP 4061 & 15.0 & 15.1 & 7.6 & 1.3 & 2.8 & 1.01 & 1.99 & 0.08 & 1.50 & 0.64 \\
\hline PT UMNH IP 4064 & 14.2 & 15.9 & 7.9 & 0.9 & 2.8 & 1.12 & 2.02 & 0.06 & 1.56 & 0.64 \\
\hline
\end{tabular}

The holotype, UMNH IP 4065 (Fig. 55A), is a fully septate specimen of $27 \mathrm{~mm}$ conch diameter that shows the characteristic globular and involute morphology of the species $(\mathrm{ww} / \mathrm{dm}=0.94 ; \mathrm{uw} / \mathrm{dm}=0.08)$. It possesses a very narrow aperture, and hence a low whorl expansion rate of only 1.42. Parts of the shell ornament are preserved; there are fine crenulated growth lines, which form a low dorsolateral projection, a shallow lateral sinus, and a low ventral projection. The internal mould shows shallow and wide constrictions, which extend parallel to the growth lines (Fig. 57G).

The largest available specimen from Hamilton Canyon is the fully septate paratype MB.C.12032.1 with $54 \mathrm{~mm}$ conch diameter (Fig. 58A). It is thinly pachyconic and involute $(\mathrm{ww} / \mathrm{dm}=0.65$, uw/dm $=0.09)$ with a low aperture $($ WER $=1.53)$. The suture line of this specimen shows a V-shaped external lobe and a subacute ventrolateral saddle (Fig. 58C). The median saddle reaches nearly half of the external lobe depth.

The suture line of holotype UMNH IP 4065 shows, at $26 \mathrm{~mm}$ conch diameter, a V-shaped external lobe with rather strongly diverging, slightly sinuous flanks, a narrowly rounded ventrolateral saddle, and an adventive lobe with strongly curved flanks (Fig. 57G).

The suture lines of the two smaller paratypes MB.C.12032.3 and UMNH IP 4061 (Fig. 57E, F), obtained 

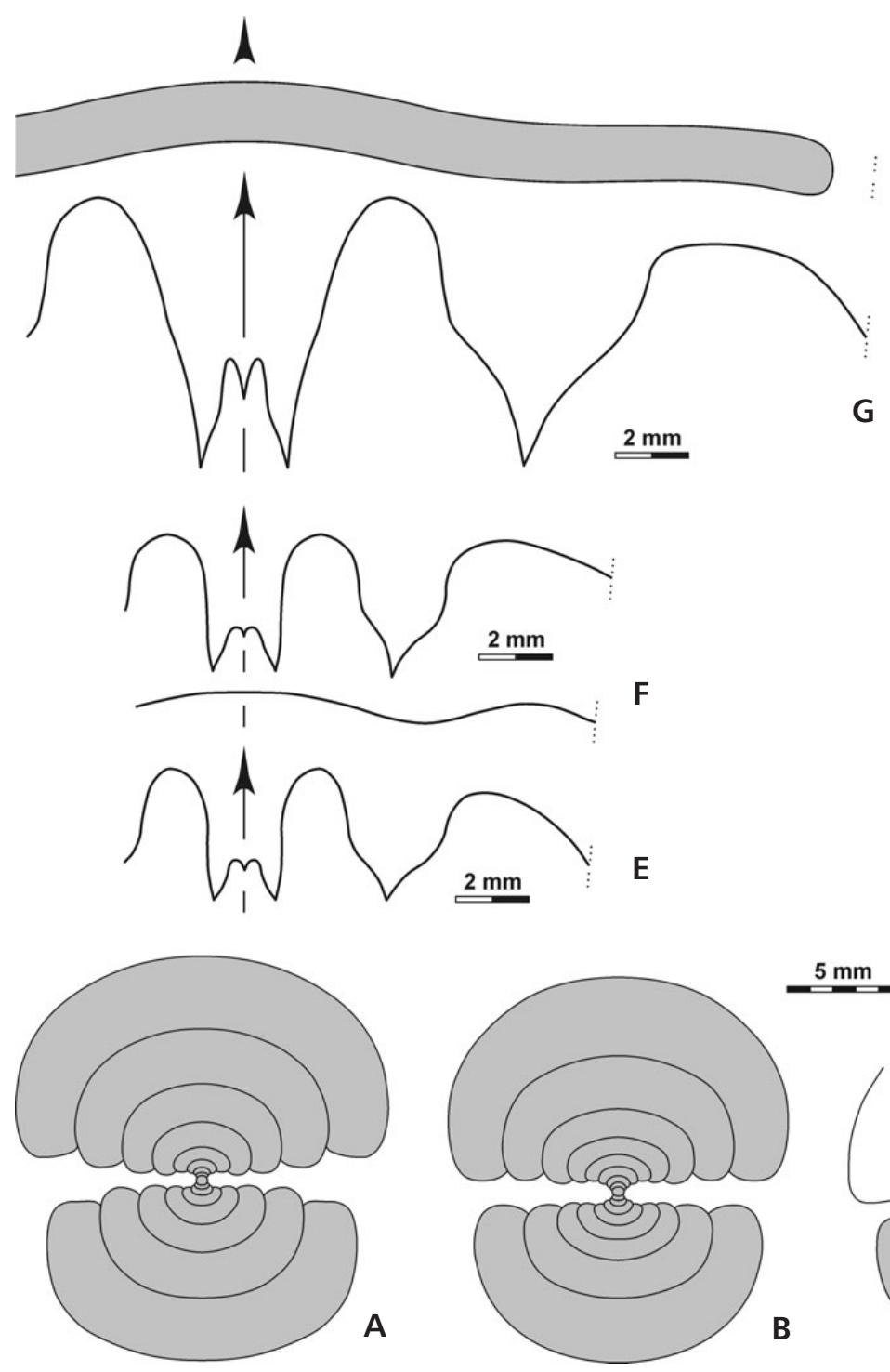
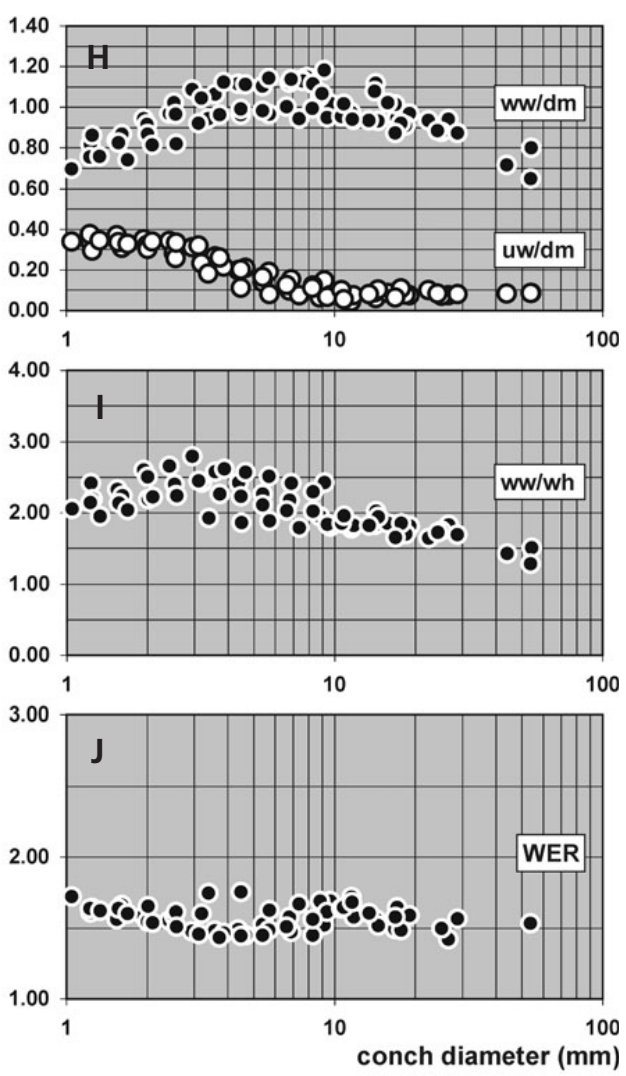

Figure 57. Goniatites sowerbyi sp. nov. • A - cross section of paratype UMNH IP 4063 from bed 28 (sample 93UTMI-27) of Jensen Wash; $\times 2.5$. - B - cross section of paratype UMNH IP 4077 from bed 44 (sample 07NVWP-3) of Hamilton Canyon; $\times 2.5$. $\bullet$ C cross section of paratype UMNH IP 4067 from bed 6 (sample 93NVLI-3) of Trough Springs Canyon; $\times 2.5$. $・$ D - cross section of paratype UMNH IP 4068 from bed 6 (sample 93NVLI-3) of Trough Springs Canyon; $\times 2.5$. $\bullet$ E - suture line of paratype MB.C.12032.3 from bed 44 of Hamilton Canyon, at $12.1 \mathrm{~mm}$ diameter, $11.2 \mathrm{~mm}$ ww, $6.2 \mathrm{~mm}$ wh; $\times 4.0 . \bullet F-$ growth line course and suture line of paratype UMNH IP 4061 from bed 25 (sample 01UTMI-5) of South Burbank Hills, at 14.3 mm diameter, $14.4 \mathrm{~mm} \mathrm{ww}, 7.6 \mathrm{~mm}$ wh; $\times$ 4.0. $\bullet \mathrm{G}$ - suture line and constriction of holotype UMNH IP 4065 from bed 6 (sample 93NVLI-3) of Trough Springs Canyon, at $25.8 \mathrm{~mm} \mathrm{dm}, 24.7 \mathrm{~mm}$ ww, $10.6 \mathrm{~mm}$ wh; $\times 4.0$. $\bullet \mathrm{H}-\mathrm{J}-$ ontogenetic development of the conch width index (ww/dm), umbilical width index (uw/dm), and whorl expansion rate (WER) of all available specimens.

at 11 and $14 \mathrm{~mm}$ conch diameter, differ from the holotype as they have parallel-sided external lobes and broadly rounded ventrolateral saddles.

Discussion. - Goniatites sowerbyi sp. nov. differs from other North American species of the genus because of its globular or spindle-shaped conch combined with a rather long subevolute early juvenile stage. Variants of G. americanus are also globular, but the inner whorls are not as widely umbilicate as in $G$. sowerbyi.
Various species of Goniatites have been shown to display wide intraspecific variability and possess more discoidal and cuboid forms (Korn et al. 2004). It can be precluded that $G$. sowerbyi is a cuboid variant of $G$. eganensis, because connecting forms appear to be completely lacking and the sutural differences are profound. G. eganensis possesses an acute ventrolateral saddle, while this is narrowly rounded in G. sowerbyi.

$G$. sowerbyi sp. nov. closely resembles the holotype of $G$. sphaericus in conch shape, but the umbilicus is slightly wider 


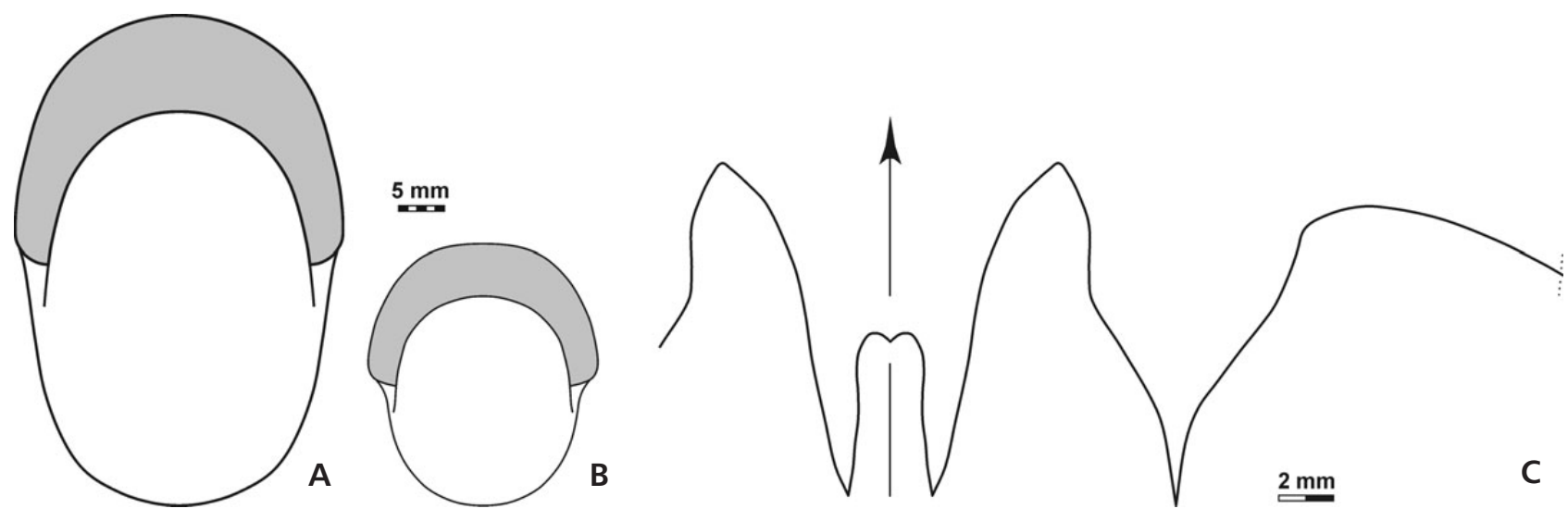

Figure 58. Goniatites sowerbyi sp. nov. from bed 44 of Hamilton Canyon. $\bullet$ A - dorsal view of paratype MB.C.12032.1; $\times 1.0$. $\bullet$ B - dorsal view of paratype MB.C.12032.2; × 1.0. • C - suture line of paratype MB.C.12032.1, at $31.0 \mathrm{~mm} w \mathrm{w}, 19.0 \mathrm{~mm}$ wh; $\times 3.0$.

Table 36. Suture line proportions (Fig. 57) for Goniatites sowerbyi sp. nov.

\begin{tabular}{lccccccc}
\hline specimen & at dm & EL w/d & EL/VLS & EL/AL & MS h & VLS w/h & remarks \\
\hline MB.C.12032.1 & $c a$ 40 & 0.50 & 1.21 & 1.08 & 0.49 & 0.41 & VL saddle subacute \\
UMNH IP 4065 & 25.8 & 0.54 & 1.05 & 0.88 & 0.41 & 0.52 & E lobe V-shaped, flanks sinuous \\
UMNH IP 4061 & 14.3 & 0.56 & 1.09 & 0.77 & 0.31 & 0.51 & E lobe parallel-sided \\
MB.C.12032.3 & 12.1 & 0.55 & 0.94 & 0.89 & 0.32 & 0.58 & E lobe parallel-sided \\
\hline
\end{tabular}

in G. sphaericus (uw/dm $=0.18$ at $22 \mathrm{~mm} \mathrm{dm}$ ). Their suture lines are also different; G. sphaericus has an acute ventrolateral saddle, which is narrowly rounded in the new species.

There is also some resemblance to the unusual taxon Sygambrites wollbriggensis Korn, 1988, which has not been reported again since its introduction and still is an enigmatic form. The latter has a very similar, but slightly wider umbilicate conch and also an ornament with crenulated, ventrally projecting growth lines. The suture line of $S$. wollbriggensis, however, is rather dissimilar, as it has a Y-shaped external lobe and a tectiform ventrolateral saddle.

Order Prolecanitida Miller \& Furnish, 1954

Suborder Prolecanitina Miller \& Furnish, 1954

Superfamily Prolecanitaceae Hyatt, 1884

Included families. - Prolecanitidae Hyatt, 1884; Daraelitidae Tchernow, 1907.

Family Daraelitidae Tchernow, 1907

Included subfamilies. - Epicanitinae Weyer, 1965; Daraelitinae Tchernow, 1907.

Subfamily Epicanitinae Weyer, 1965

Included genera. - Epicanites Schindewolf, 1926; Librovitchites Andrianov, 1985; Praedaraelites Schindewolf,
1934; Rotocanites Weyer, 1965 [synonym of Praedaraelites Schindewolf, 1934].

\section{Genus Praedaraelites Schindewolf, 1934}

Type species. - Daraelites culmiensis Kobold, 1933 (original designation).

Genus definition. - Epicanitinae with a suture line of which at least the adventive lobe is notched; other lobes are occasionally serrated.

Included species. - acutus: Praedaraelites (Praedaraelites) acutus Ruan, 1981, p. 167; Guangxi; aktubensis: Praedaraelites aktubensis Ruzhencev, 1949, p. 740; South Urals; apiculus: Praedaraelites (Praedaraelites) apiculus Ruan, 1981, p. 166; Guangxi; bowlandensis: Epicanites bowlandensis Moore, 1952, p. 73; Lancashire [synonym of P. culmiensis]; culmiensis: Daraelites culmiensis Kobold, 1933, p. 506; Harz; curtus: Praedaraelites (Rotocanites) curtus Ruan, 1981, p. 170; Guangxi; dangeardi: Epicanites dangeardi Pareyn, 1961, p. 91; Western Algeria; densus: Praedaraelites (Praedaraelites) densus Liang \& Wang, 1991, p. 65; Xinjiang; inflatus: Praedaraelites (Rotocanites) inflatus Liang \& Wang, 1991, p. 69; Xinjiang; involutus: Praedaraelites (Praedaraelites) involutus Ruan, 1981, p. 167; Guangxi; loeblichi: Epicanites loeblichi Miller \& Furnish, 1940, p. 372; Oklahoma; longilobatus: Praedaraelites 

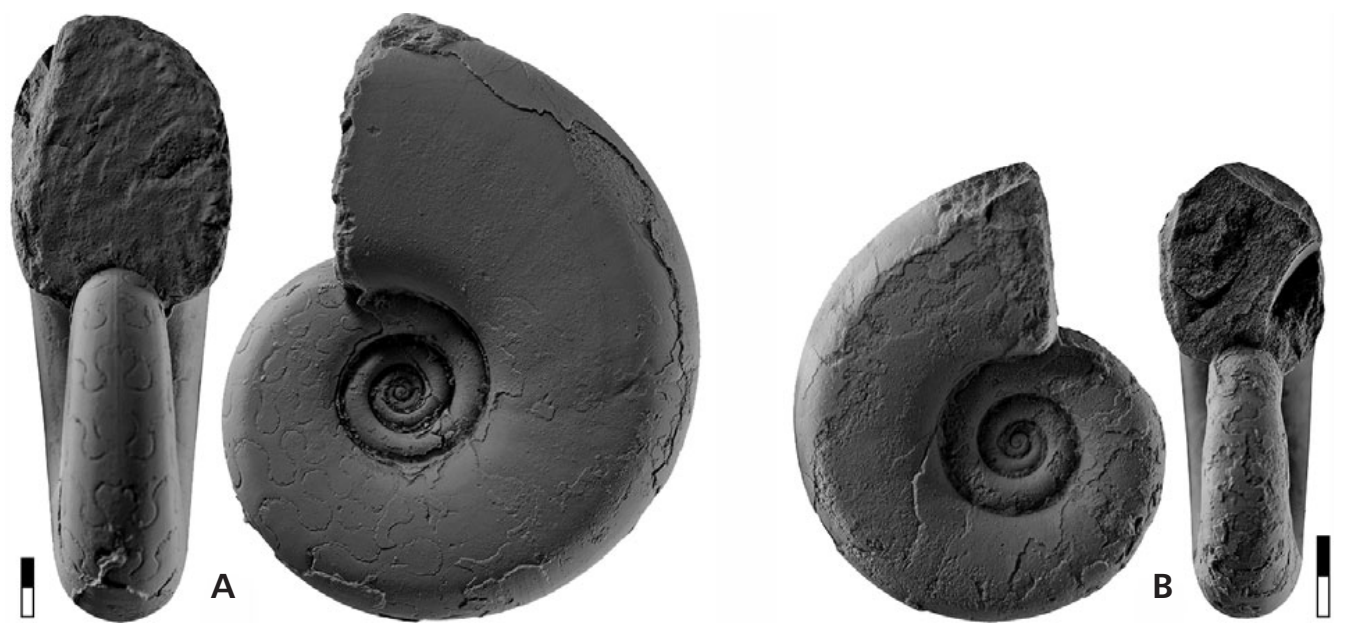

Figure 59. Praedaraelites loeblichi (Miller \& Furnish, 1940). A - specimen UMNH IP 4096 from bed 44 (sample 07NVWP-3) of Hamilton Canyon; $\times$ 3.0. $\bullet$ B - specimen UMNH IP 4095 from bed 28 (sample 93UTMI-27) of Jensen Wash; $\times$ 4.0.

(Rotocanites) longilobatus Liang \& Wang, 1991, p. 66; Xinjiang; medius: Praedaraelites (Praedaraelites) medius Liang \& Wang, 1991, p. 65; Xinjiang; nandanensis: Praedaraelites (Rotocanites) nandanensis Ruan, 1981, p. 169; Guangxi; orientalis: Praedaraelites (Rotocanites) orientalis Ruan, 1981, p. 168; Guangxi; ovalis: Praedaraelites ovalis Sheng, 1983, p. 51; Tibet; postculmiensis: Praedaralites postculmiensis Kullmann, 1963, p. 352; Cantabrian Mountains [synonym of $P$. saharensis]; praecursor: Daraelites praecursor Fromaget, 1931, p. 659; Laos; pyrenaicus: Daraelites praecursor pyrenaicus Delépine, 1935, p. 174; Pyrenees; quadratus: Praedaraelites (Praedaraelites) quadratus Ruan, 1981, p. 168; Guangxi; saharensis: Praedaraelites praecursor var. saharensis Pareyn, 1961, p. 92; Western Algeria; simulans: Praedaralites simulans Kullmann, 1963, p. 349; Cantabrian Mountains [synonym of $P$. dangeardi]; sobolevi: Epicanites sobolevi Kusina, 1999, p. 47; Novaya Zemlya; viriosus: Praedaraelites (Praedaraelites) viriosus Ruan, 1981, p. 165; Guangxi; xinjiangensis: Praedaraelites (Rotocanites) xinjiangensis Liang \& Wang, 1991, p. 67; Xinjiang.

Discussion. - The relationships between the genera Epicanites Schindewolf, 1926 and Praedaraelites Schindewolf, 1934 are not solved. The only difference between the two genera is the presence or absence of lobe serration, a character that may be only of specific value. Both genera belong to the very slowly evolving daraelitids, possessing very similar conch morphologies that allow only rarely the clear separation of species. In the following, the separation of the two genera is used tentatively because of the distinct septal inflexions causing the serration of the adventive lobe.

More than twenty species of Praedaraelites have been described so far (AMMON database; Korn \& Ilg 2010), and fourteen of these from occurrences in China alone. Most of the species are not well characterised and some of these may be treated as synonyms. The genus is widely distributed, but very rare in the western United States. It is restricted to distinct stratigraphic horizons in North Africa, Iberia, North-west and Central Europe, but stratigraphically more variable in the South Urals and North China.

\section{Praedaraelites loeblichi (Miller \& Furnish, 1940)}

Figures 59, 60

1940 Epicanites loeblichi Miller \& Furnish, p. 372, pl. 48, figs 13-16.

Holotype. - Specimen 1410 (State University Iowa), illustrated by Miller \& Furnish (1940) on pl. 48, figs 14-16.

Type locality and horizon. - South of Ada, Pontotoc Co., Oklahoma; lower Caney Shale, Goniatites multiliratus Biozone.

Material. - 15 specimens; conch diameter up to $21 \mathrm{~mm}$.

Diagnosis. - Species of Praedaraelites with a combination of stronger denticulation of the adventive lobe and a less pouched, lower external lobe (width/depth ratio of external lobe is 0.67 ) than other species.

Description. - The best-preserved specimen UMNH IP 4096 from Hamilton Canyon. It has a diameter of $20.4 \mathrm{~mm}$ and consists of a chambered internal mould with half a volution of body chamber also preserved (Fig. 59A). This specimen illustrates the transformation of the juvenile serpenticonic conch with circular whorl cross section into the thin discoidal, moderately umbilicate adult morphology $(\mathrm{ww} / \mathrm{dm}=0.36 ; \mathrm{uw} / \mathrm{dm}=0.27)$ with remarkable heightening of the aperture (WER increasing to a value of 2.80), 

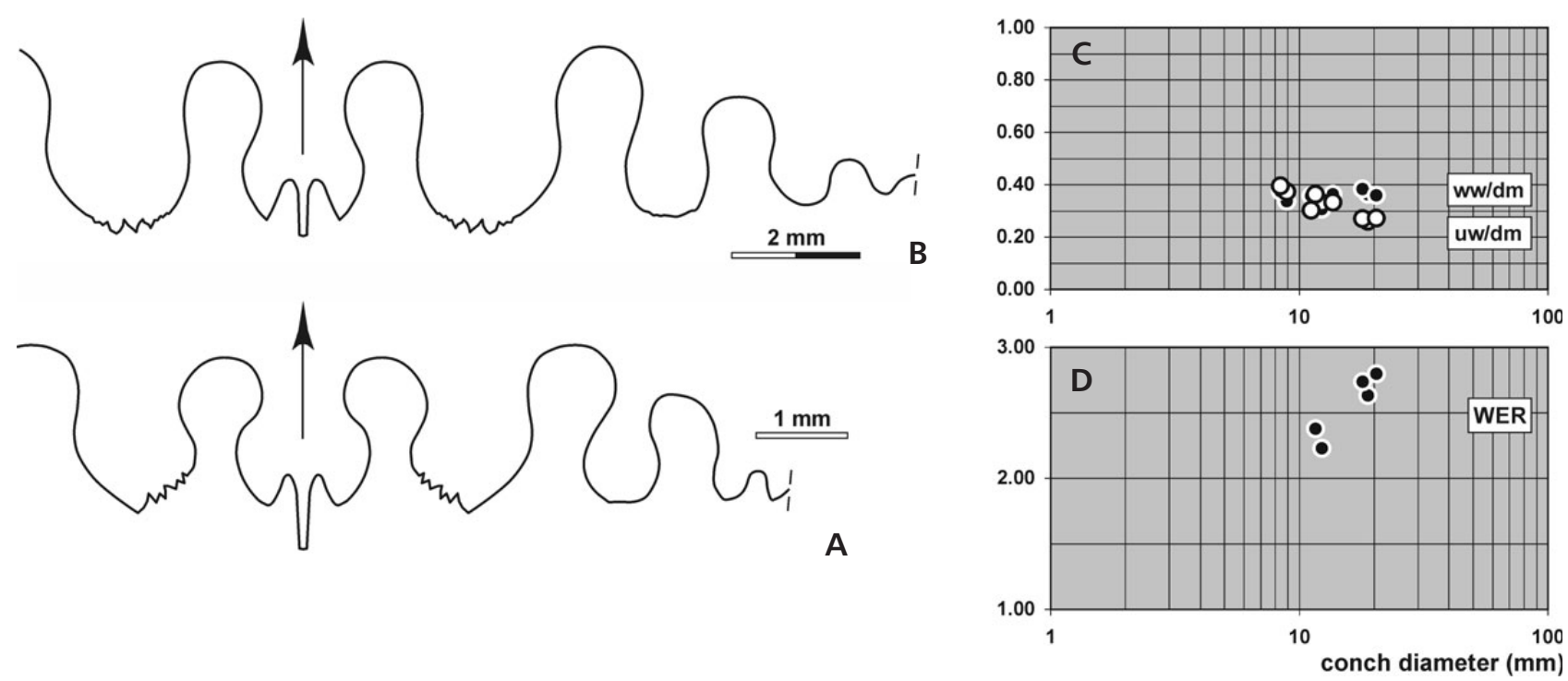

Figure 60. Praedaraelites loeblichi (Miller \& Furnish, 1940). A - suture line of specimen UMNH IP 4096 from bed 44 (sample 07NVWP-3) of Hamilton Canyon, at $4.4 \mathrm{~mm}$ ww, $5.1 \mathrm{~mm}$ wh; $\times 10.0$. B - suture line of specimen UMNH IP 4100 from bed 25 (sample 01UTMI-5) of South Burbank Hills, at $19.1 \mathrm{~mm}$ diameter, $6.9 \mathrm{~mm}$ ww, $8.8 \mathrm{~mm}$ wh; $\times$ 7.0. $\bullet \mathrm{C}, \mathrm{D}-$ ontogenetic development of the conch width index (ww/dm), umbilical width index (uw/dm), and whorl expansion rate (WER) of all available specimens.

Table 37. Conch dimensions (in mm) and proportions for reference specimens of Praedaraelites loeblichi (Miller \& Furnish, 1940).

\begin{tabular}{lccccccccccc}
\hline & $\mathrm{dm}$ & ww & wh & uw & ah & ww/dm & ww/wh & uw/dm & WER & IZR \\
\hline UMNH IP 4096 & 20.4 & 7.4 & 10.8 & 5.6 & 8.2 & 0.36 & 0.68 & 0.27 & 2.80 & 0.24 \\
UMNH IP 4100 & 18.9 & 6.9 & 8.9 & 4.9 & 7.3 & 0.36 & 0.77 & 0.26 & 2.63 & 0.18 \\
UMNH IP 4102 & 18.0 & 6.9 & 9.1 & 4.9 & 7.1 & 0.38 & 0.76 & 0.27 & 2.74 & 0.22 \\
UMNH IP 4093 & 12.3 & 3.8 & 4.3 & 4.1 & 4.1 & 0.31 & 0.88 & 0.33 & 2.23 & 0.05 \\
UMNH IP 4095 & 11.6 & 4.1 & 4.4 & 4.2 & 4.1 & 0.35 & 0.93 & 0.36 & 2.38 & 0.07 & \\
holotype 1410 & 9.0 & 3.1 & 3.3 & 3.6 & 3.1 & 0.34 & 0.94 & 0.40 & 2.33 & 0.06 \\
\hline
\end{tabular}

flattened flanks, and an oblique umbilical wall. Only some patches of shell are preserved, they show very delicate growth lines, which appear to be strongest on the umbilical wall.

The suture line of specimen UMNH IP 4100 shows the characteristic criteria for the genus (Fig. 60B). The external lobe is slightly pouched in its lower half; its width is two thirds of the lobe depth, and the width of the lower part is 1.35 of the width in the upper half where the lobe flanks converge. A narrow, pouched ventrolateral saddle follows on the ventrolateral shoulder, which is in turn succeeded by an adventive lobe that is the most prominent sutural element, being 1.16 times wider than the external lobe and having an asymmetric, drop-shaped outline. It is distinctly serrated at its base, with the largest denticles in the centre. These denticles are visible as delicate marginal inflexions on the septum. An additional three lobes are present on the flank and umbilical wall; the outer of these is also drop-shaped but narrow with a cragged base and the other two are rounded. These lobes are separated by rounded, partly pouched saddles. Lobes and saddles have the same width in this area.
The suture of specimen UMNH IP 4096 shows, in an earlier stage, similar elements (Fig. 60A). The external lobe is more strongly pouched, and the adventive lobe shows a denticulation on its ventral side. The adventive lobe has a blunt base and lacks denticulation.

Discussion. - The type material from the Caney Shale consists of small specimens, of which the largest (holotype 1410) has a conch diameter of only $9 \mathrm{~mm}$. At this stage, the denticulation of the lobes is not developed, as proven by the new material. The holotype displays the immature morphology of the species with a rather wide umbilicus and a shell ornament consisting of well-visible growth lines like the small specimens newly collected from the Chainman Formation.

With so many previously named species of Praedaraelites, several of which are not clearly defined, the validity of the various species might be questioned. However, $P$. loeblichi displays a very distinctive suture line, with a unique combination of stronger denticulation of the adventive lobe with only incipient pouching of the shallow external lobe (in $P$. culmiensis, the width/depth ratio of the external lobe is 0.85 in contrast to 0.67 in P. loeblichi). 


\section{Acknowledgements}

We would like to thank Barry Richards (Calgary), Nick Riley (Nottingham), Kevin Bylund (Provo) for assistance in the field. Technical support (photography, fossil preparation) was provided by Wolfgang Gerber (Tübingen), Evelin Stenzel, and David Schmelzle (Berlin). Logistical support was provided by the U.S. Bureau of Land Management (BLM). DK acknowledges financial support by the German Research Foundation (Deutsche Forschungsgemeinschaft; project KO1829/6-1). We also thank the reviewers Kenneth de Baets and Christian Klug (Zurich) for their useful comments.

\section{References}

ANDRIANOv, V.N. 1985. Permskie i nekotorye kamennougolnye ammonoidei Severo-Vostoka Azii. Trudy Geologicheskogo Instituta (Novosibirsk), Izdatel'stvo Nauka Sibirskoye Otdeleniye, $1-180$.

ArthaBer, G. von 1911. Die Trias von Albanien. Beiträge zur Paläontologie Österreich-Ungarns und des Orients 24, 169-288.

BARRANDE, J. 1870. Système Silurien du centre de la Bohême. I. Vol. 2, Céphalopodes, série 4. 804 pp. Prague \& Paris.

Bisat, W.S. 1924. The Carboniferous goniatites of the North of England and their zones. Proceedings of the Yorkshire Geological Society 2, 40-124.

Bisat, W.S. 1928. The Carboniferous goniatite zones of England and their continental equivalents. Compte Rendue Congrès International de Stratigraphie et de Géologie du Carbonifère (Heerlen 1927), 117-133.

BisAT, W.S. 1934. The goniatites of the Beyrichoceras zone in the north of England. Proceedings of the Yorkshire Geological Society 22, 280-309. DOI 10.1144/pygs.22.4.280

BisAT, W.S. 1952. The goniatite succession at Cowdale Clough, Barnoldswick, Yorkshire. Transactions of the Leeds Geologist Association 6(4), 155-181.

Bockwinkel, J., Korn, D. \& Ebbighausen, V. 2010. The ammonoids from the Argiles de Timimoun of Timimoun (Early and Middle Viséan; Gourara, Algeria). Fossil Record 13(1), 215-278. DOI 10.1002/mmng.200900013

Bogoslovskaya, M.F. 1966. Rod Goniatites i ego predstavateli na Yuzhnom Urale. Paleontologicheskiy Zhurnal 1966(1), $38-46$.

BRAndon, A. \& Hodson, F. 1984. The stratigraphy and palaeontology of the late Viséan and early Namurian rocks of North-east Connaught. Geological Survey of Ireland, Special Paper 6, 1-54.

Branson, C.C., Elias, M.K. \& Amsden, T.W. 1959. Type of Goniatites choctawensis. Oklahoma Geology Notes 19(8), 157-164.

Brown, T. 1841. Description of some New Species of Fossil Shells, found chiefly in the Vale of Todmorden, Yorkshire. Transactions of the Manchester Geological Society 1, 211-232.

BRÜNING, K. 1923. Beiträge zur Kenntnis des Rheinisch-westfälischen Unterkarbons, insbesondere der Goniatiten und Korallen in der stratigraphischen Stellung und Gliederung. 59 pp. Marburg University, Marburg.
Campbell, K.S.W., Brown, D.A. \& Coleman, A.R. 1983. Ammonoids and the correlation of the lower Carboniferous rocks of eastern Australia. Alcheringa 7(2), 75-123.

DOI 10.1080/03115518308619623

Collinson, C.W. 1955. Mississippian prolecanitid goniatites from Illinois and adjacent areas. Journal of Paleontology 29, 433-438.

Conil, R., Groessens, M.L., Poty, E. \& Tourneur, F. 1990. Carboniferous guide foraminifera, corals, and conodonts in the Franco-Belgian and Campine basins: their potential for widespread correlation. Courier Forschungsinstitut Senckenberg $130,15-30$.

Cozar, P., Somerville, I.D., Aretz, M. \& Herbig, H.-G. 2005. Biostratigraphical dating of upper Viséan limestones (NW Ireland) using foraminiferans, calcareous algae and rugose corals. Irish Journal of Earth Sciences 23, 1-23.

CurrIE, E.D. 1954. Scottish Carboniferous Goniatites. Transactions of the Royal Society of Edinburgh 622(14), 527-602.

Delépine, G. 1935. Contribution à l'étude de la faune du Dinantien des Pyrénées. Deuxième partie: La faune de Mondette. Bulletin de la Société Géologique de France 5(5), 171-191.

DeléPINe, G. 1940. Les goniatites du Dinantien de la Belgique. Mémoires du Musée Royal d'Histoire Naturelle de Belgique 91, 1-91.

DeléPINE, G. 1941. Les goniatites du Carbonifère du Maroc et des confins Algéro-Marocains du Sud (Dinantien-Westphalien). Notes et mémoires, Service Géologique, Protectorat de la République Française au Maroc, Direction de la Production Industrielle et des Mines, Division des Mines et de la Géologie $56,1-111$.

Dollé, L. 1912. Le Dinantien supérieur (Viséen) de la vallée de l'Oued-Zousfana. Annales de la Société Géologique du Nord 41, 240-261.

Drahovzal, J.A. 1972. The Lower Carboniferous Genus Goniatites. Proceedings of the International Paleontological Union, $3^{\text {rd }}$ International Geological Congress Praha, section evolution, 15-52.

Drahovzal, J.A. \& QuinN, J.H. 1972. A new Goniatites species from the Chesterian of Arkansas. Journal of Paleontology 46, 581-590.

Eisbacher, G.H. 1983. Devonian-Mississippian sinistral transcurrent faulting along the cratonic margin of western North America: a hypothesis. Geology 11, 7-10. DOI 10.1130/0091-7613(1983)11<7:DSTFAT>2.0.CO;2

ELIAS, M.K. 1956. Upper Mississippian and lower Pennsylvanian Formations of South-Central Oklahoma. Petroleum Geology of Southern Oklahoma, American Association of Petroleum Geologists 1956, 56-134.

Foord, A.H. 1903. Monograph of the Carboniferous Cephalopoda of Ireland, Part V, Containing the families Glyphioceratidae (concluded) and Prolecanitidae, with title-page and index. Palaeontographical Society 57, 147-234.

Foord, A.H. \& CRICK, G.C. 1897. Catalogue of the fossil Cephalopoda in the British Museum (Natural History). Part III. Containing the Bactritidae, and part of the suborder Ammonoidea. xxiii + 303 pp. Dulau \& Co., London.

FRECH, F. 1906. A tengeri eredetü Karbon Magyarországon. Földtani Közlöny 36, 1-50. 
FRECH, F. 1897-1902. Lethaea geognostica oder Beschreibung und Abbildung der für die Gebirgs-Formationen bezeichnendsten Versteinerungen. I. Theil. Lethaea palaeozoica. 2. Band. 578 pp. Schweizerbart, Stuttgart.

Fromaget, J. 1931. Note sur le Daraelites des calcaires d'âge Namurien de la province du Cammon (Moyen Laos). Bulletin de la Société Géologique de France 1931, 659-661.

GABB, W.M. 1862. Descriptions of new species of American Tertiary fossils and a new Carboniferous cephalopod from Texas. Proceedings of the Academy of Natural Sciences of Philadelphia 1861, 367-372.

GaO Yue-YIng 1983. Cephalopoda, 452-475. In XI'An Institute of Geology and Mineral Resources (ed.) Paleontological Atlas of Northwestern China. Shaanxi, Gansu and Ningxia. Part II. Upper Paleozoic. Geological Publishing House, Beijing.

GiRTY, G.H. 1909. The fauna of the Caney Shale of Oklahoma. Bulletin of the United States Geological Survey 377, 1-106.

GIRTY, G.H. 1911. The fauna of the Moorefield Shale of Arkansas. Bulletin of the United States Geological Survey 439, $1-148$.

Gischler, E. \& Korn, D. 1992. Goniatiten des Ober-Viseums aus Decksedimenten des Iberger Riffes, Oberharz. Neues Jahrbuch für Geologie und Paläontologie, Abhandlungen 185(3), 271-288.

Gordon, M. JR. 1957. Missisippian Cephalopods of Northern and Eastern Alaska. Professional Papers of the United States Geological Survey 283, 1-61.

Gordon, M. JR. 1962. Species of Goniatites in the Caney Shale of Oklahoma. Journal of Paleontology 36, 355-357.

GoRdON, M. JR. 1965. Carboniferous Cephalopods of Arkansas. Professional Papers of the United States Geological Survey $460,1-322$.

Gordon, M. JR. 1970. Carboniferous ammonoid zones of the south-central and western United States. Compte rendu, Congrès International de Stratigraphie et de Géologie $d u$ Carbonifère 2, 817-826.

Gordon, M. JR. 1971. Goniatites americanus n. sp., a late Meramec (Mississippian) index fossil. Geological Survey Research 1971, C39-C43.

GoRdon, M. Jr. 1986. Late Kinderhookian (Early Mississippian) Ammonoids of the Western United States. Journal of Paleontology, Memoirs 19, 1-36.

Gordon, M. JR., Hose, R.K. \& Repenning, C.A. 1957. Goniatite zones in the Chainman Shale equivalents (Mississippian), western Utah. Geological Society of America Bulletin 68, 1737.

HAAn, G. DE 1825. Monographia Ammoniteorum et Goniatiteorum. 168 pp. Hazenberg, Lugduni Batavorum.

Hall, J. \& Whitfield, R.P. 1877. Paleontology. United States Geologic Exploration of the $40^{\text {th }}$ Parallel (King) Report 4, 198-302.

Haug, E. 1898. Études sur les goniatites. Mémoires de la Société Géologique de France 18, 1-112.

Hind, W. 1918. On the distribution of the British Carboniferous Goniatites, with a description of one new genus and some new species. Geological Magazine 5(10), 434-450. DOI 10.1017/S0016756800203920

HintZe, L.H. 1974. Preliminary geologic map of the Conger
Mountain Quadrangle, Millard County, Utah. United States Geological Survey, map MF-634.

Hintze, L.H. 1986. Geologic map of the Mormon Gap and Tweedy Wash Quadrangles, Millard County, Utah, and Lincoln and White Pine Counties, Nevada. United States Geological Survey, map MF-1872.

HinTZE, L.H. 1997. Interim geologic map of the Big Jensen Pass Quadrangle, Millard County, Utah. Utah Geological Survey, map OFR-357.

Hintze, L.H. \& Best, M.G. 1987. Geologic map of the Mountain Home Pass and Miller Wash Quadrangles, Millard and Beaver Counties, Utah, and Lincoln County, Nevada. United States Geological Survey, map MF-1950.

Hodson, F. 1954. A new species of Dimorphoceras from the Homoceras Zone of the Irish Millstone Grit. The annals and magazine of natural history, zoology, botany and geology, new series 12(7), 362-366.

Hodson, F. \& Moore, E.W.J. 1959. Goniatites striatus and related forms from the Viséan of Ireland. Palaeontology 1(4), 384-396.

Holzapfel, E. 1889. Die Cephalopoden-führenden Kalke des unteren Carbon von Erdbach-Breitscheid bei Herborn. Palaeontologische Abhandlungen, Neue Folge 5(1), 1-74.

Hose, R.K. 1974. Geologic map of the Granite Mountain SW quadrangle, Juab and Millard counties, Utah. United States Geological Survey, map I-831.

Hose, R.K. \& BlaKe, M.C. 1976. Geology and mineral resources of White Pine County, Nevada, Part I - Geology. Nevada Bureau of Mines and Geology, Bulletin 85, 1-35.

Hose, R.K. \& RePENNING, C.A. 1964. Geologic map and sections of the Cowboy Pass SW Quadrangle, Confusion Range Millard County, Utah. United States Geological Survey, map I-390.

Hose, R.K. \& ZionY, J.I. 1963. Geologic map and sections of the Gandy NE Quadrangle Confusion Range, Millard County, Utah. United States Geological Survey, map I-376.

HuH, O.K. 1968. Mississippian stratigraphy and sedimentology across the Wasatch Line, east-central Idaho and extreme southwestern Montana. 175 pp. Ph.D. dissertation, Penn State University.

Humphrey, F.L. 1960. Geology of the White Pine mining district, White Pine County, Nevada. Nevada Bureau of Mines and Geology, Bulletin 57, 1-119.

Hyatt, A. 1883-1884. Genera of fossil cephalopods. Proceedings of the Boston Society of Natural History 22, 253-338.

Hyatт, A. 1900. Tetrabranchiate Cephalopoda, 502-604. In Zittel, K.A. von Text-book of palaeontology. Volume 1, $1^{\text {st }}$ edition. 839 pp. Macmillan and Co., London.

King, P.B. 1965. Geology of the Sierra Diablo Region, Texas. United States Geological Survey, Professional Paper 480, $1-185$.

KitTL, E. 1904a. Geologie der Umgegend von Sarajewo. Jahrbuch der Kaiserlich-Königlichen Geologischen Reichsanstalt 53 (for 1903), 515-748.

KitTL, E. 1904b. Entogonites, eine Cephalopodengattung aus dem bosnischen Kulm. Verhandlungen der KaiserlichKöniglichen Geologischen Reichsanstalt 14, 322.

Kleinhampl, F.J. \& Ziony, J.I. 1985. Geology of northern Nye County, Nevada. Nevada Bureau of Mines and Geology, Bulletin 99A, 1-172. 
Klug, C., Döring, S., Korn, D. \& Ebbighausen, V. 2006. The Viséan sedimentary succession at the Gara el Itima (Anti-Atlas, Morocco) and its ammonoid faunas. Fossil Record 9(1), 3-60. DOI 10.1002/mmng.200600001

KNAPP, W.D. 1965. Mississippian Cephalopods of the Eastern Interior United States. 208 pp. Doctoral dissertation, State University of Iowa, Iowa City, Iowa.

Kobold, A. 1933. Die Gliederung des Oberharzer Kulms nach Goniatiten. Stratigraphische Beobachtungen im Kulm des nordwestlichen Oberharzes unter besonderer Berücksichtigung der Grauwacken. Jahrbuch der Preußischen Geologischen Landesanstalt 53 (for 1932), 450-515.

Koninck, L.G. DE 1844. Description des animaux fossiles qui se trouvent dans le terrain Carbonifère de la Belgique. IV + 716 pp. Dessain, Liège.

KoninCK, L.G. DE 1880. Faune du Calcaire Carbonifère de la Belgique, deuxième partie, Genres Gyroceras, Cyrtoceras, Gomphoceras, Orthoceras, Subclymenia et Goniatites. Annales du Museé Royal d'Histoire Naturelle, Belgique 5, 1-333.

Korn, D. 1988. Die Goniatiten des Kulmplattenkalkes (Cephalopoda, Ammonoidea; Unterkarbon; Rheinisches Schiefergebirge). Geologie und Paläontologie in Westfalen 11, 1-293.

Korn, D. 1990. Weitere Goniatiten aus dem Ober-Visé des Sauerlandes (Cephalopoda, Ammonoidea; Unterkarbon; Rheinisches Schiefergebirge). Geologie und Paläontologie in Westfalen 15, 11-69.

KonN, D. 1993. Stratigraphie und Fossilführung der Visé/Namur-Aufschlüsse am Bau der A46 bei Arnsberg/Westfalen. Geologie und Paläontologie in Westfalen 23, 35-60.

KoRn, D. 1996. Revision of the Rhenish Late Viséan goniatite stratigraphy. Annales de la Société géologique de Belgique 117, 205-212.

KonN, D. 1997a. Evolution of the Goniatitaceae and ViséanNamurian biogeography. Acta Palaeontologica Polonica 42, 177-199.

KonN, D. 1997b. The Palaeozoic ammonoids of the South Portuguese Zone. Memórias do Instituto Geológico e Mineiro 33, $1-131$.

Konn, D. 2010. A key for the description of Palaeozoic ammonoids. Fossil Record 13(1), 5-12. DOI 10.1002/mmng.200900008

Korn, D., Bockwinkel, J. \& EbBighausen, V. 2007. Tournaisian and Viséan ammonoid stratigraphy in North Africa. Neues Jahrbuch für Geologie und Paläontologie, Abhandlungen 243(2), 127-148. DOI 10.1127/0077-7749/2007/0243-0127

Korn, D., Bockwinkel, J. \& Ebbighausen, V. 2010. The ammonoids from the Argiles de Teguentour of Oued Temertasset (early Late Tournaisian; Mouydir, Algeria). Fossil Record 13(1), 35-152. DOI 10.1002/mmng.200900010

Korn, D., Bockwinkel, J., Ebbighausen, V. \& Klug, C. 2003b. Palaeobiogeographic and evolutionary meaning of an early Late Tournaisian ammonoid fauna from the Tafilalt of Morocco. Acta Palaeontologica Polonica 48(1), 71-92.

Korn, D. \& Ebbighausen, V. 2008. The Early Carboniferous (Mississippian) ammonoids from the Chebket el Hamra (Jerada Basin, Morocco). Fossil Record 11(2), 83-156. DOI 10.1002/mmng.200800004

Korn, D., Ebbighausen, V., Bockwinkel, J. \& Klug, C. 2003 a. The A-mode sutural ontogeny in prolecanitid ammonoids.
Palaeontology 46(6), 1123-1132.

DOI 10.1046/j.0031-0239.2003.00336.x

Korn, D., Jovanović, D., NovaK, M. \& Sudar, M.N. 2010. Early Late Viséan ammonoid faunas from the Jadar Block (NW Serbia). Geologica Carpathica 61(5), 355-364.

DOI 10.2478/v10096-010-0021-4

Korn, D. \& Horn, K. 1997. The Late Viséan (Early Carboniferous) goniatite stratigraphy in the South Portuguese Zone, a comparison with the Rhenish Massif. Newsletters on Stratigraphy 35, 97-113.

Korn, D. \& ILG, A. 2010. AMMON, www.wahre-staerke.com/ ammon/.

KoRn, D. \& Kaufmann, B. 2009. A high-resolution relative time scale for the Viséan Stage (Carboniferous) of the Kulm Basin (Rhenish Mountains, Germany). Geological Journal 44(3), 306-321.

Korn, D. \& KLuG, C. 2007. Conch Form Analysis, Variability, Morphological Disparity, and Mode of Life of the Frasnian (Late Devonian) Ammonoid Manticoceras from Coumiac (Montagne Noire, France), 57-85. In Landman, N.H., Davis, R.A. \& MAPes, R.H. (eds) Cephalopods Present and Past: New Insights and Fresh Perspectives. Springer, New York. DOI 10.1007/978-1-4020-6806-5_3

Korn, D., Klug, C. \& MAPES, R.H. 1999. Viséan and Early Namurian Ammonoids from the Tafilalt (Eastern Anti-Atlas, Morocco). Abhandlungen der Geologischen Bundesanstalt 54, 345-375.

Korn, D., KLug, C. \& MAPES, R.H. 2004. Cuboid Carboniferous ammonoids. Mitteilungen aus dem Geologisch-Paläontologischen Institut der Universität Hamburg 88, 79-97.

Korn, D., Klug, C. \& MAPES, R.H. 2005. The Lazarus ammonoid family Goniatitidae, the tetrangularly coiled Entogonitidae, and Mississippian biogeography. Journal of Paleontology $79(2), 356-365$.

DOI 10.1666/0022-3360(2005)079<0356:TLAFGT>2.0.CO;2

Korn, D. \& Tilsley, J.W. 2006. Ammonoid assemblages from the Asbian $\mathrm{B}_{2} \mathrm{~b}$ (Early Carboniferous: Mississippian) buildups of the Peak District, England. Proceedings of the Yorkshire Geological Society 56(2), 111-150.

DOI 10.1144/pygs.56.2.111

Kossmat, F. 1895. Untersuchungen über die Südindische Kreideformation. Beiträge zur Paläontologie und Geologiew Österreich-Ungarns und des Orients 9, 97-203.

Kullmann, J. 1961. Die Goniatiten des Unterkarbons im Kantabrischen Gebirge (Nordspanien). I. Stratigraphie. Paläontologie der U.O. Goniatitina Hyatt. Neues Jahrbuch für Geologie und Paläontologie, Abhandlungen 113(3), 219-326.

Kullmann, J. 1962. Die Goniatiten der Namur-Stufe (Oberkarbon) im Kantabrischen Gebirge, Nordspanien. Abhandlungen der Akademie der Wissenschaften und der Literatur, Mainz, mathematisch-naturwissenschaftliche Klasse 1962(6), 259-377.

Kullmann, J. 1963. Die Goniatiten des Unterkarbons im Kantabrischen Gebirge (Nordspanien). II. Paläontologie der U.O. Prolecanitina Miller \& Furnish. Die Altersstellung der Faunen. Neues Jahrbuch für Geologie und Paläontologie, Abhandlungen 116(3), 269-324.

Kumpera, O. \& LANG, V. 1975. Goniatitová fauna v kulmu Drahanské vysočiny (moravskoslezská zóna Českého masívu). 
Časopis Slezského muzea v Opavě, Series A - historia naturalis 24, 11-32.

KusinA, L.F. 1971. O nekotorykh novykh i maloizvestnykh ranevizeyskikh (saurskikh) ammonoideyakh. Paleontologicheskiy Zhurnal 1971(1), 37-48.

KusinA, L.F. 1980. Saurskie ammonoidei. Trudy Paleontologicheskogo Instituta Akademiya Nauk SSSR 181, 1-108.

KusInA, L.F. 1987. Viseyskiy kompleks ammonoidei. Paleontologicheskiy Zhurnal 1987(1), 52-61.

Kusina, L.F. \& Lazarev, S.S. 1994. Novye rannekamennougol'nye ammonoidei Mongolii. Paleontologicheskiy Zhurnal 28(1A), 157-171.

Kusina, L.F. \& Poletaev, V.I. 1991. Novye Vizeyskie ammonoidei Donbassa i Dneprovsko-Donetskoy Vpadiny. Paleontologicheskiy Zhurnal 1991(3), 35-45.

Kusina, L.F. \& Yатsкov, S.V. 1987. Kamenougolnye ammonoidei milinkoy svity Novoy Zemli. Doklady Moskovskaya obshchestva ispytatelei prirody, Otdelenie geologii 62, 101-108.

Kusina, L.F. \& YATSKov, S.V. 1988. Rannekamenougolnye ammonoidei Novoy Zemli. Paleontologicheskiy Zhurnal 1988(1), 28-39.

Kusina, L.F. \& Yatskov, S.V. 1999. Nizhne- i srednekamennougolnye ammonoidei Novoi Zemli. Trudy Paleontologicheskogo Instituta Rossiyskaya Akademiya Nauk 275, 1-144.

Liang Xiluo \& Gao Yujing 1963. Carboniferous Cephalopoda, 95-96. In ZHAO, J. (ed.) Handbook of Index fossils from Northwest China 84. Science Press, Beijing.

Liang Xiluo \& Wang Minglian 1991. Carboniferous cephalopods of Xinjiang. Palaeontologia Sinica, Series B 180, 1-171.

LiBRovitCH, L.S. 1957. O nekotorykh novykh gruppakh goniatitov iz kamennougolnykh otlozheniy SSSR. Ezhegodnik Vsesoyuznogo Paleontologicheskogo Obshchestva 16, 246-272.

MANGER, W.L. 1988. Phylogeny of the Carboniferous Ammonoid Family Dimorphoceratidae, 29-42. In Wiedmann, J. \& KulLMAnN, J. (eds) Cephalopods - Present and Past. Schweizerbart, Stuttgart.

Manger, W.L. \& PAReYn, C. 1979. New Carboniferous dimorphoceratid ammonoids from Algeria and Arkansas. Journal of Paleontology 53(3), 657-665.

MANGER, W.L. \& Quinn, J.H. 1972. Carboniferous dimorphoceratid ammonoids from northern Arkansas. Journal of Paleontology 46, 303-314.

Maples, C.G. \& Waters, J.A. 1987. Redefinition of the Meramecian/Chesterian boundary (Mississippian). Geology 15(7), 647-651.

DOI 10.1130/0091-7613(1987)15<647:ROTMBM>2.0.CO;2

Martin, W. 1809. Petrificata Derbiensia; or, Figures and Descriptions of Petrifactions collected in Derbyshire. 28 pp. D. Lyon, Wigan.

McCaleb, J.A., Quinn, J.H. \& Furnish, W.M. 1964. The ammonoid family Girtyoceratidae in the Southern Midcontinent. Circular of the Oklahoma Geological Survey 67, 1-41.

Meischner, D. \& Nemyrovska, T. 1999. Origin of Gnathodus bilineatus (Roundy, 1926) related to goniatite zonation in Rheinisches Schiefergebirge, Germany. Bollettino della Società Paleontologica Italiana 37(2-3), 427-442.

Miller, A.K. \& Furnish, W.M. 1940. Studies on Carboniferous ammonoids: parts 1-4. Journal of Paleontology 14, 356-377.
Miller, A.K. \& Furnish, W.M. 1954. The classification of the Paleozoic ammonoids. Journal of Paleontology 28, 685-692.

Miller, A.K. \& Garner, H.F. 1953. The goniatite genus Prolecanites in America. Journal of Paleontology 27, 814-816.

Miller, A.K. \& Owen, J.B. 1937. A new Pennsylvanian cephalopod fauna from Oklahoma. Journal of Paleontology 11, $403-422$.

Miller, A.K. \& Youngquist, W. 1948. The cephalopod fauna of the Mississippian Barnett Formation of Central Texas. Journal of Paleontology 22, 649-671.

Miller, A.K., Downs, H.R. \& Youngquist, W. 1949. Some Mississippian cephalopods from central and western United States. Journal of Paleontology 23, 600-612.

Miller, A.K., YoungQuist, W. \& Nielsen, M.L. 1952. Mississippian cephalopods from western Utah. Journal of Paleontology $26,148-161$.

Miller, S.A. \& Faber, C. 1892. Description of some Subcarboniferous and Carboniferous Cephalopoda. Journal of the Cincinati Society of Natural History 14, 164-168.

Miller, S.A. \& GuRLEy, W.F.E. 1896. New species of Palaeozoic invertebrates from Illinois and other states. Bulletin of the Illinois State Museum of Natural History 11, 1-50.

Moore, E.W.J. 1930. Species of the Genus Dimorphoceras in the Bowland Shales. Geological Magazine 67, 162-168. DOI 10.1017/S0016756800099131

Moore, E.W.J. 1936. The Bowland Shales from Pendle to Dinckley. Journal of the Manchester Geological Association 1936, 167-192.

Moore, E.W.J. 1939. The goniatite genus Dimorphoceras and its development in the British Carboniferous. Proceedings of the Yorkshire Geological Society 24(2), 103-128.

DOI 10.1144/pygs.24.2.103

MoORE, E.W.J. 1946. The Carboniferous Goniatite Genera Girtyoceras and Eumorphoceras. Proceedings of the Yorkshire Geological Society 25, 387-445. DOI 10.1144/pygs.25.6.387

Moore, E.W.J. 1952. Notes on the genera Prolecanites and Epicanites with description of two new species. Liverpool and Manchester Geological Journal 1(1), 71-76.

Moore, E.W.J. 1958. Dimorphoceratidae from the Upper Viséan shales of County Leitrim, Eire. Proceedings of the Yorkshire Geological Society 31(3), 219-226.

DOI 10.1144/pygs.31.3.219

Morgan, G.D. 1924. Geology of the Stonewall quadrangle, Oklahoma. Bureau of Geology Bulletin 2, 185-186.

Mull, C.G., Tailleur, I.L., Mayfield, C.F., Ellersiek, I. \& Curtis, S.M. 1982. New upper Paleozoic and lower Mesozoic stratigraphic units, central and western Brooks Range, Alaska. Bulletin of the American Association of Petroleum Geologists 1982, 348-362.

MÜNSTER, G. GRAF ZU 1832. Ueber die Planuliten und Goniatiten im Uebergangs-Kalk des Fichtelgebirges. 38 pp. Birner, Bayreuth.

Nicolaus, H.-J. 1963. Zur Stratigraphie und Fauna der crenistria-Zone im Kulm des Rheinischen Schiefergebirges. Beihefte zum Geologischen Jahrbuch 53, 1-246.

Oliveira, J.T. \& Wagner-Gentis, C.H.T. 1983. The Mértola and Mira formation boundary between Dogueno and Almada de Ouro, marine Carboniferous of South Portugal, 1-39. In 
Lemos de Sousa, M.J. (ed.) Contributions to the Carboniferous Geology and Palaeontology of the Iberian Peninsula. 259 pp. Universidade do Porto, Porto.

Padget, P. 1952. A new species of Beyrichoceras from the "Yoredale beds", County Tyrone, Northern Ireland. The annals and magazine of natural history, zoology, botany and geology, new series 12(5), 864-868.

Pareyn, C. 1961. Les Massifs Carbonifères du Sahara SudOranais. Tome II. Paléontologie stratigraphique. Publications du Centre de Recherches Sahariennes, Série Géologie 1, 1-244.

Petersen, M.S., Korn, D. \& Kullmann, J. 2000. The early Mississippian (Osagean) ammonoid Dzhaprakoceras (Cephalopoda) from Utah. Journal of Paleontology 74(5), 853-857. DOI 10.1666/0022-3360(2000)074<0853:TEMOAD>2.0.CO;2

PHILliPs, J. 1836. Illustrations of the geology of Yorkshire; or a description of the strata and organic remains; accompanied by a geological map, sections, and diagrams, and figures of the fossils. Part II. The Mountain Limestone District. XX + 259 pp. John Murray, London.

Plummer, F.B. \& ScotT, G. 1937. Upper Paleozoic ammonites in Texas. The geology of Texas, Bulletin of the Texas University 3701, 1-516.

Poole, F.G. \& SAndberg, C.A. 1991. Mississippian paleogeography and conodont biostratigraphy of the western United States, 107-136. In Cooper, J.D. \& Stevens, C.H. (eds) Paleozoic paleogeography of the western United States-II: Pacific Section of the Society of Economic Paleontologists and Mineralogists 67.

Popov, A.V. 1968. Vizeyskie ammonoidei cevernogo TyanShanya i ikh stratigraficheskoe zhachenie. Trudy Geologicheskiy Instituta, Kirgizskiy Filial Akademiya Nauk SSSR, $1-116$.

Poty, E. \& Hance, L. 2006. Warnantian. Geologica Belgica 9, 139-144.

Ramsвоттом, W.H.C. 1970. Some British Carboniferous goniatites of the family Anthracoceratidae. Bulletin of the Geological Survey of Great Britain 32, 53-60.

Ramsbottom, W.H.C. \& Saunders, W.B. 1985. Evolution and evolutionary biostratigraphy of Carboniferous ammonoids. Journal of Paleontology 59, 123-139.

RePETSKi, J.E. \& StAmm, R. 2009. Mississippian conodonts of the Appalachian Basin, 59-61. In GreB, S.F. \& CHesnut, D.R. (eds) Carboniferous of the Appalachian and Black Warrior Basins. Kentucky Geological Survey, Special Publication 10.

RILEY, N.J. 1993. Dinantian (Lower Carboniferous) biostratigraphy and chronostratigraphy in the British Isles. Journal of the Geological Society, London 150, 427-446. DOI 10.1144/gsjgs.150.3.0427

Riley, N.J. 1996. Mid-Dinantian ammonoids from the Craven Basin, northwest England. Special Papers in Palaeontology 53, 1-87.

Roemer, F.A. 1850. Beiträge zur geologischen Kenntnis des nordwestlichen Harzgebirges. Palaeontographica 3, 1-69.

Roemer, F.A. 1855. Beiträge zur geologischen Kenntniss des nordwestlichen Harzgebirges. Zweite Abtheilung. Palaeontographica 3, 69-111.

RUAN YI-PING 1981. Carboniferous Ammonoid faunas from Qixu in Nandan of Guangxi. Memoirs of the Nanjing Institute of Geology and Palaeontology, Academia Sinica 15, 153-232.
Ruzhencev, V.E. 1947. Predstabiteli semeystva Dimorphoceratidae Hyatt v kamennougolnykh otlozheniyakh Urala. Doklady Akademiya Nauk SSSR 56(5), 521-524.

RuZHENCEV, V.E. 1949. Sistematika i evolyutsia semeystv Pronoritidae Frech i Medlicottiidae Karpinsky. Trudy Paleontologicheskogo Instituta Akademiya Nauk SSSR 19, 1-206.

Ruzhencev, V.E. 1957. Filogeneticheskaya sistema paleozoiskikh ammonoidei. Byulleten' Moskovskogo Obshchestva Ispytateley Prirody, Otdel Geologicheskiy 32(2), 49-64.

RuzHenCEv, V.E. 1960. Printsipy sistematiki, sistema i filogeniya paleozoyskikh ammonoidey. Trudy Paleontologicheskogo Instituta Akademiya Nauk SSSR 133, 1-331.

RuZHENCEV, V.E. 1966. Vizeyskie ammonoidei na yuzhnom Urale. Paleontologicheskiy Zhurnal 1966(1), 47-59.

RuZHENCEV, V.E. 1975. Ammonoidei i khronostratigrafiya Karbona vostochnoy Sibiri. Paleontologicheskiy Zhurnal 1975(2), 28-45.

Ruzhencev, V.E. \& Bogoslovskaya, M.F. 1969. Reviziya semeystva Dimorphoceratidae. Paleontologicheskiy Zhurnal 1969(1), 51-66.

Ruzhencev, V.E. \& BogoslovsKaya, M.F. 1970. Reviziya nadsemeystva Goniatitaceae. Paleontologicheskiy Zhurnal 1970(4), 52-65.

Ruzhencev, V.E. \& Bogoslovskaya, M.F. 1971. Namyurskiy etap v evolyutsii ammonoidey. Rannenamyurskie ammonoidei. Trudy Paleontologicheskogo Instituta Akademiya Nauk SSSR 133, 1-382.

SADLICK, W.L. 1960. Some preliminary aspects of Chainman stratigraphy, 81-90. In Boetcher, J.W. \& SLOAN, W.W. JR. (eds) Guidebook to the geology of east-central Nevada: Intermountain Association of Petroleum Geologists, $11^{\text {th }}$ Annual Field Conference.

SADLICK, W.L. 1965. Biostratigraphy of the Chainman Formation (Carboniferous), eastern Nevada and western Utah. 237 pp. Ph.D. dissertation, Salt Lake City, University of Utah.

SADLICK, W.L. 1995. Stratigraphic subdivision of the Chainman Formation, 3-27. In HANSEN, M.W., WalKer, J.P. \& TREXLER, J.H. JR. (eds) Mississippian source rocks in the Antler Basin of Nevada and associated structural and stratigraphic traps. Fieldtrip Guidebook. Nevada Petroleum Society, Inc., Reno, Nevada.

SAndberg, C.A., Morrow, J.R. \& Poole, F.G. 2008. New Meramecian unit on Mississippian Granite Mountain Island, Middle Range, west-central Utah. Geological Society of America, Joint Rocky Mountain and Cordilleran Sections Annual Meeting Abstracts with Programs, 41.

SAnDBerg, C.A., Poole, F.G. \& Gutschick, R.C. 1980. Devonian and Mississippian stratigraphy and conodont zonation of Pilot and Chainman Shales, Confusion Range, Utah, 71-79. In Fouch, T.D. \& Magathan, E.R. (eds) Paleozoic paleogeography of the west-central United States. Rocky Mountain Paleogeography Symposium I. Rocky Mountain Section, Society of Economic Paleontologists and Mineralogists, Denver, Colorado.

SAundERs, W.B. 1966. New Goniatite Ammonoid from the Late Mississippian of Arkansas. Oklahoma Geology Notes 26(2), 43-48.

SAunders, W.B., MAnger, W.L. \& Gordon, M. JR. 1977. Upper 
Mississippian and lower and middle Pennsylvanian ammonoid biostratigraphy of Northern Arkansas. Oklahoma Geological Survey Guidebook 18, 117-137.

Schindewolf, O.H. 1926. Beiträge zur Kenntnis der Cephalopodenfauna des oberfränkisch-ostthüringischen Unterkarbons. Senckenbergiana 8, 63-96.

Schindewolf, O.H. 1934. Über zwei jungpaläozoische Cephalopodenfaunen von Menorca. Abhandlungen der Gesellschaft der Wissenschaften in Göttingen, Mathematisch-Physikalische Klasse III 10, 159-191.

SchindewOlF, O.H. 1951. Über ein neues Vorkommen unterkarbonischer Pericyclus-Schichten im Oberharz. Neues Jahrbuch für Geologie und Paläontologie, Abhandlungen 93(1), 23-116.

Schmid, H. 1925. Die carbonischen Goniatiten Deutschlands. Jahrbuch der Preußischen Geologischen Landesanstalt 45 (for 1924), 489-609.

Schmid, H. 1934. Cephalopodenfaunen des älteren Namur aus der Umgegend von Arnsberg in Westfalen. Jahrbuch der Preußischen Geologischen Landesanstalt 54 (for 1933), 440-461.

Schmid, H. 1941. Eine neue Fauna mit Pericyclus von Riefensbeek im Harz. Jahrbuch der Reichsstelle für Bodenforschung 60 (for 1939), 148-156.

Sellers, D.H.A. \& Furnish, W.M. 1960. Mississippian ammonoids from northwestern Canada. Journal of Paleontology 34, $1124-1128$.

ShEng HuAiBin 1983. The ammonoids of late Lower Carboniferous from Yongzhu village, Xainza district in North Xizang. The Geology of the Qinghai-Xizang (Tibet) Plateau, Beijing, 41-68.

Shumard, B.F. 1863. Descriptions of new Paleozoic fossils. Transactions of the St. Louis Academy of Science 2, 108-113.

Silberling, N.J., Nichols, K.M., Macke, D.L. \& TrapPe, J. 1995. Upper Devonian-Mississippian stratigraphic sequences in the distal Antler foreland of western Utah and adjoining Nevada. United States Geological Survey Bulletin 1988-H, 1-33.

Skompski, S., Paszkowski, M., Krobicki, M., Kokovin, K., Korn, D., Tomas, A. \& Wrzolek, T. 2001. Depositional setting of the Devonian/Carboniferous biohermal Bolshaya Nadota Carbonate Complex, Subpolar Urals. Acta Geologica Polonica 51, 217-235.

Sмiтh, J.P. 1897. The development of Glyphioceras and the phylogeny of the Glyphioceratidae. Proceedings of the California Acadademy of Science, Geology 1(3), 105-122.

Smith, J.P. 1903. The Carboniferous Ammonoids of America. Monographs of the United States Geological Survey 42, 1-211.

SOWERBY, J. 1812-1814. The mineral conchology of Great Britain; or coloured figures and descriptions of those remains of testaceous animals or shells, which have been preserved at various times and depths in the earth. Vol. I. 234 pp. London.

TCHernow, A.A. 1907. Artinskian Stage. I. Ammonoids from the basins of Yayvy, Kos'vy, and Chusovoy. 1. Introduction. Review of investigated area. Prolecanitidae. Byulleten' Moskovskogo Obshchestva Ispytateley Prirody, Otdel Geologicheskiy 20(34), 270-401.

Titus, A.L. 1999. Ammonoid biostratigraphy of the Barnett Shale (late Mississippian), Texas, USA, 155-168. In RozAnov, A.Y. \& Shevyrev, A.A. (eds) Fossil cephalopods: Recent advances in their study. Paleontologicheskogo Instituta Rossiyskaya Akademiya Nauk, Moskva.

Titus, A.L. 2000. Late Mississippian (Arnsbergian Stage- $\mathrm{E}_{2}$ chronozone) ammonoid paleontology and biostratigraphy of the Antler foreland basin, California. Bulletin of the Utah Geological Survey 131, 1-108.

Titus, A.L. \& Manger, W.M. 2001. Mid-carboniferous ammonoid biostratigraphy, southern Nye County, Nevada: Implications of the first North American Homoceras. Journal of Paleontology, Supplement 4, 55, 1-31. DOI 10.1666/0022-3360(2001)75[1:MABSNC]2.0.CO;2

Trexler, J.H. JR., Snyder, W., Schwarz, D., Kurka, M.T. \& Crosby, R. 1995. An overview of the Mississippian Chainman Shale. In HANSEN, M.W., WALKeR, J.P. \& TREXLER, J.H. (eds) Mississippian Source Rocks in the Antler Basin of Nevada and Associated Structural and Stratigraphic Traps. Fieldtrip Guidebook. 165 pp. Nevada Petroleum Society, Reno, Nevada.

Tschanz, C.M. \& Pampeyan, E.H. 1970. Geology and mineral deposits of Lincoln County, Nevada. Nevada Bureau of Mines and Geology Bulletin 73, 1-188.

Tynan, M.C. 1980. Conodont biostratigraphy of the Mississippian Chainman Formation, western Millard County, Utah. Journal of Paleontology 54, 1282-1309.

WANG Ming-Qian 1983. Cephalopoda, 514-533. In Regional Geological Surveying Team of Xinjiang \& Xinjiang GeoLOGiCAl Bureau et al. (eds) Fossil Atlas of Northwest China, Xinjiang 2. Geological Publishing House, Beijing.

Webster, G.D., Gordon, M. JR., Langenheim, R.L. JR. \& Henry, T.W. 1984. Road logs for the Mississippian-Pennsylvanian boundary in the eastern Great Basin; Salt Lake City, Utah, to Las Vegas, Nevada, Field trip 1, 1-86. In LinTZ, J. JR. (ed.) Western geologic excursions, volume 1. Department of Geological Sciences, University of Nevada at Reno.

WedEKInD, R. 1918. Die Genera der Palaeoammonoidea Goniatiten). Mit Ausschluß der Mimoceratidae, Glyphioceratidae und Prolecanitidae. Paläontographica 62, 85-184.

Weyer, D. 1965. Zur Ammonoideen-Fauna der GattendorfiaStufe von Dzikowiec (Ebersdorf) in Dolny Slask (Niederschlesien). Berichte der geologischen Gesellschaft der DDR 10(4), 443-464.

Weyer, D. 1972. Trilobiten und Ammonoideen aus der Entogonites nasutus-Zone (Unterkarbon) des Büchenberg-Sattels (Elbingeröder Komplex, Harz). Teil I. Geologie 21(2), 166-184.

Work, D.M., NassichuK, W.W. \& Richards, B.C. 2000. Lower Viséan ammonoids from the lower Mount Head Formation, east-central British Columbia. Geological Survey of Canada Bulletin 541, 1-17.

Worthen, A.H. 1890. Description of fossil invertebrates. Geological Survey of Illinois 8, 148-150.

YANG FENGQING 1986. Late Early Carboniferous ammonoids from Chenmazijing of Zhongning, Ningxia. Acta Palaeontologica Sinica 25(3), 260-271.

YoungQuist, W. 1949a. The cephalopod fauna of the White Pine Shale of Nevada. Journal of Paleontology 23, 276-305.

YoungQuist, W. 1949b. The cephalopod fauna of the White Pine Shale of Nevada: Supplement. Journal of Paleontology 23, 613-616. 


\section{Appendix - Material used for the description of the ammonoid fauna (additional, in the stratigraphic columns mentioned but not catalogued material available)}

Material in the Utah Museum of Natural History (Titus coll.):

Duckwater Hills; bed 4 (sample 93NVNY-1)

Goniatites deceptus sp. nov.

Hamilton Canyon; bed 44 (sample 95NVWP-16)

Girtyoceras hamiltonense sp. nov.

Hamilton Canyon; bed 44 (sample 07NVWP-3)

Girtyoceras hamiltonense sp. nov.

Metadimorphoceras richardsi sp. nov.

Goniatites eganensis sp. nov.

Goniatites sowerbyi sp. nov.

Praedaraelites loeblichi (Miller \& Furnish, 1940)

Hamilton Canyon; bed 44 (sample 95NVWP-15)

Girtyoceras hamiltonense sp. nov.

Metadimorphoceras richardsi sp. nov.

Trough Springs Canyon; bed 6 (sample 93NVLI-3)

Goniatites eganensis sp. nov.

Goniatites sowerbyi sp. nov.

Granite Mountain South; bed 17 (sample 94UTJU-1)

Entogonites sp.

Calygirtyoceras confusionense sp. nov.

Calygirtyoceras arcticum (Gordon, 1957)

Dimorphoceras rileyi sp. nov.

Kazakhoceras bylundi sp. nov.

Goniatites americanus Gordon, 1971

Praedaraelites loeblichi (Miller \& Furnish, 1940)

Granite Mountain South; bed 17 (sample 07UTJU-1)

Bollandoceras occidentale sp. nov.

Entogonites sp.

Calygirtyoceras arcticum (Gordon, 1957)

Dimorphoceras rileyi sp. nov.

Kazakhoceras bylundi sp. nov.

Goniatites americanus Gordon, 1971

Granite Mountain South; bed 22 (sample 94UTJU-2)

Goniatites americanus Gordon, 1971

Granite Mountain South; bed 25 (sample 94UTJU-4)

Entogonites acus sp. nov.

Calygirtyoceras arcticum (Gordon, 1957)

Girtyoceras primum sp. nov.

Dimorphoceras rileyi sp. nov.

Dimorphoceratidae sp. indet.

Goniatites americanus Gordon, 1971

Praedaraelites loeblichi (Miller \& Furnish, 1940)

Granite Mountain South; bed 25 (sample 05UTJU-12)

Entogonites acus sp. nov.

Calygirtyoceras arcticum (Gordon, 1957)
23 specimens (UMNH IP 3845-3867)

3 specimens (UMNH IP 3188-3190)

23 specimens (UMNH IP 3127-3149)

2 specimens (UMNH IP 3290-3291)

10 specimens (UMNH IP 4010-4019)

1 specimen (UMNH IP 4077)

4 specimens (UMNH IP 4096-4099)

9 specimens (UMNH IP 3179-3187)

1 specimen (UMNH IP 3293)

41 specimens (UMNH IP 4020-4061)

12 specimens (UMNH IP 4065-4076)

2 specimens (UMNH IP 2680-2681)

15 specimens (UMNH IP 2692-2706)

10 specimens (UMNH IP 2751-2760)

7 specimens (UMNH IP 3245-3246-3248-3252)

2 specimens (UMNH IP 3305-3311)

30 specimens (UMNH IP 3547-3575-3753)

1 specimen (UMNH IP 4093)

1 specimen (UMNH IP 2635)

1 specimen (UMNH IP 2679)

4 specimens (UMNH IP 2779-2782)

8 specimens (UMNH IP 3253-3260)

1 specimen (UMNH IP 3306)

9 specimens (UMNH IP 3450-3458)

32 specimens (UMNH IP 3488-3519)

2 specimens (UMNH IP 2660-2661)

18 specimens (UMNH IP 2761-2778)

70 specimens (UMNH IP 2977-3046)

1 specimen (UMNH IP 3247)

1 specimen (UMNH IP 3267)

127 specimens (UMNH IP 3576-3702)

1 specimen (UMNH IP 4094)

1 specimen (UMNH IP 2655)

5 specimens (UMNH IP 2718-2722) 
Girtyoceras primum sp. nov.

Girtyoceras primum sp. nov.

Dimorphoceras rileyi $\mathrm{sp}$. nov.

Goniatites americanus Gordon, 1971

Granite Mountain South; bed 25 (sample 04UTJU-3)

Goniatites americanus Gordon, 1971

Granite Mountain South; bed 33 (sample 94UTJU-3b)

Goniatites deceptus sp. nov.

Granite Mountain North; bed 25 (sample 94UTJU-9)

Entogonites acus sp. nov.

Calygirtyoceras arcticum (Gordon, 1957)

Girtyoceras primum sp. nov.

Dimorphoceras rileyi $\mathrm{sp}$. nov.

Goniatites americanus Gordon, 1971

Granite Mountain North; bed 33 (sample 97UTJU-4)

Goniatites deceptus sp. nov.

Granite Mountain North; bed 33 (sample 05UTJU-13)

Goniatites deceptus sp. nov.

Granite Mountain North; bed 35 (sample 94UTJU-10)

Goniatites deceptus sp. nov.

Granite Mountain North; bed 35 (sample 05UTJU-14)

Goniatites deceptus sp. nov.

Middle Confusion Range 1; bed 6 (sample 07UTMI-3)

Dimorphoceratidae sp. indet.

Goniatites americanus Gordon, 1971

Middle Confusion Range 1; bed 10 (sample 05UTMI-3)

Bollandoceras occidentale sp. nov.

Kazakhoceras bylundi sp. nov.

Goniatites americanus Gordon, 1971

Middle Confusion Range 1; bed 10 (sample 07UTMI-4) Goniatites americanus Gordon, 1971

Middle Confusion Range 1; bed 12 (sample 05UTMI-5) Dimorphoceratidae sp. indet.

Goniatites americanus Gordon, 1971

Middle Confusion Range 2; bed 11 (sample 05UTMI-9)

Bollandoceras sp.

Goniatites americanus Gordon, 1971

Middle Confusion Range 2; bed 14 (sample 05UTMI-7) Goniatites americanus Gordon, 1971

Middle Confusion Range 2; bed 15 (sample 07UTMI-6) Dimorphoceratidae sp. indet.

Middle Confusion Range 3; bed 10 (sample 05UTMI-10)

Dimorphoceratidae sp. indet.

Goniatites americanus Gordon, 1971
9 specimens (UMNH IP 2951-2959)

3 specimens (UMNH IP 3090-3092)

1 specimen (UMNH IP 3240)

34 specimens (UMNH IP 3392-3418-3520-3525-3800)

2 specimens (UMNH IP 3290-3291)

2 specimens (UMNH IP 3965-3966)

2 specimens (UMNH IP 2656-2657)

13 specimens (UMNH IP 2723-2739-2750)

43 specimens (UMNH IP 3047-3089)

3 specimens (UMNH IP 3230-3243-3244)

60 specimens (UMNH IP 3703-3752-3754-3763)

11 specimens (UMNH IP 3818-3823-3960-3965)

7 specimens (UMNH IP 3830-3832-3968-3972)

67 specimens (UMNH IP 3816-3817-3868-3932)

1 specimen (UMNH IP 3833)

1 specimen (UMNH IP 3265)

2 specimens (UMNH IP 3359-3360)

5 specimens (UMNH IP 2630-2634)

2 specimens (UMNH IP 3309-3310)

5 specimens (UMNH IP 3434-3438)

6 specimens (UMNH IP 3361-3366)

1 specimen (UMNH IP 3264)

5 specimens (UMNH IP 3445-3449)

1 specimen (UMNH IP 2636)

5 specimens (UMNH IP 3441-3444)

2 specimens (UMNH IP 3439-3240)

1 specimen (UMNH IP 3266)

2 specimens (UMNH IP 3270-3271)

15 specimens (UMNH IP 3419-3433) 
Conger Mountain West; bed 19 (sample 01UTMI-42)

Dimorphoceratidae sp. indet.

Goniatites deceptus sp. nov.

Conger Mountain West; bed 19 (sample 01UTMI-43)

Goniatites deceptus sp. nov.

Conger Mountain West; bed 21 (sample 01UTMI-40)

Dimorphoceratidae sp. indet.

Goniatites deceptus sp. nov.

Conger Mountain East; bed 14 (sample 01UTMI-48)

Dimorphoceratidae sp. indet.

Goniatites americanus Gordon, 1971

Conger Mountain East; bed 16 (sample 01UTMI-49)

Goniatites deceptus sp. nov.

Goniatites sowerbyi sp. nov.

Needle Range 1; bed 16 (sample 00UTMI-1n)

Girtyoceras primum sp. nov.

Dimorphoceratidae sp. indet.

Goniatites americanus Gordon, 1971

Needle Range 1; bed 18, 19 (sample 00UTMI-6n)

Dimorphoceratidae sp. indet.

Goniatites americanus Gordon, 1971

Needle Range 1; single bullion (sample 07UTMI-10)

Entogonites acus sp. nov.

Goniatites americanus Gordon, 1971

South Burbank Hills; bed 5 (sample 01UTMI-2)

Entogonites burbankensis sp. nov.

Entogonites sp.

Dimorphoceras worki sp. nov.

Metadimorphoceras mangeri sp. nov.

Goniatites americanus Gordon, 1971

South Burbank Hills; bed 6 (sample 01UTMI-3)

Calygirtyoceras arcticum (Gordon, 1957)

Girtyoceras primum sp. nov.

Metadimorphoceras mangeri sp. nov.

Goniatites americanus Gordon, 1971

South Burbank Hills; bed 8 (sample 07UTMI-6)

Entogonites acus sp. nov.

Calygirtyoceras arcticum (Gordon, 1957)

Girtyoceras primum sp. nov.

South Burbank Hills; bed 14 (sample 01UTMI-4)

Girtyoceras gordoni sp. nov.

Dimorphoceras rileyi sp. nov.

Goniatites americanus Gordon, 1971

South Burbank Hills; bed 15 (sample 07UTMI-8)

Goniatites americanus Gordon, 1971
1 specimen (UMNH IP 3263)

7 specimens (UMNH IP 3834-3837-3993-3995)

15 specimens (UMNH IP 3945-3959)

1 specimen (UMNH IP 3262)

13 specimens (UMNH IP 3972-3984)

1 specimen (UMNH IP 3261)

12 specimens (UMNH IP 3786-3797)

13 specimens (UMNH IP 3985-3992)

1 specimen (UMNH IP 4064)

30 specimens (UMNH IP 2834-2863)

1 specimen (UMNH IP 3268)

1 specimen (UMNH IP 3312)

1 specimen (UMNH IP 3269)

3 specimens (UMNH IP 3313-3315)

2 specimens (UMNH IP 2658-2659)

22 specimens (UMNH IP 3764-3785)

4 specimens (UMNH IP 2637-2640)

1 specimen (UMNH IP 2678)

1 specimen (UMNH IP 3229)

6 specimens (UMNH IP 3278-3283)

26 specimens (UMNH IP 3316-3351)

5 specimens (UMNH IP 2728-2737)

87 specimens (UMNH IP 2864-2950)

5 specimens (UMNH IP 3273-3277)

20 specimens (UMNH IP 3352-3371)

1 specimen (UMNH IP 2662)

12 specimens (UMNH IP 2783-2794)

13 specimens (UMNH IP 2960-2972)

8 specimens (UMNH IP 3093-3100)

4 specimens (UMNH IP 3233-3279-3239)

18 specimens (UMNH IP 3372-3389)

6 specimens (UMNH IP 3467-3472) 
South Burbank Hills; bed 24 (sample 07UTMI-2)

Girtyoceras gordoni sp. nov.

Dimorphoceras rileyi sp. nov.

South Burbank Hills; bed 26 (sample 07UTMI-1) Girtyoceras hamiltonense sp. nov.

Girtyoceras sp.

Metadimorphoceras richardsi sp. nov.

Goniatites eganensis sp. nov.

South Burbank Hills; bed 26 (sample 01UTMI-5)

Girtyoceras hamiltonense sp. nov.

Metadimorphoceras richardsi sp. nov.

Goniatites eganensis sp. nov.

Goniatites sowerbyi sp. nov.

Praedaraelites loeblichi (Miller \& Furnish, 1940)

Jensen Wash; bed 7 (sample 93UTMI-25)

Entogonites borealis Gordon, 1957

Entogonites sp.

Calygirtyoceras confusionense sp. nov.

Calygirtyoceras arcticum (Gordon, 1957)

Calygirtyoceras sp.

Dimorphoceras rileyi sp. nov.

Metadimorphoceras mangeri sp. nov.

Metadimorphoceras sp.

Goniatites americanus Gordon, 1971

Jensen Wash; bed 7 (sample 97UTMI-9)

Entogonites borealis Gordon, 1957

Calygirtyoceras confusionense sp. nov.

Dimorphoceras rileyi sp. nov.

Kazakhoceras bylundi sp. nov.

Goniatites americanus Gordon, 1971

Jensen Wash; bed 9 (sample 97UTMI-10)

Entogonites borealis Gordon, 1957

Entogonites sp.

Dimorphoceratidae sp. indet.

Goniatites americanus Gordon, 1971

Jensen Wash; bed 13 (sample 97UTMI-12)

Entogonites acus sp. nov.

Girtyoceras primum sp. nov.

Goniatites americanus Gordon, 1971

Jensen Wash; bed 19 (sample 97UTMI-13)

Girtyoceras gordoni sp. nov.

Dimorphoceras rileyi sp. nov.

Kazakhoceras bylundi sp. nov.

Jensen Wash; bed 26 (sample 97UTMI-14)

Goniatites sp.

Jensen Wash; bed 28 (sample 90UTMI-11)

Goniatites deceptus sp. nov.

Goniatites sowerbyi sp. nov.

Praedaraelites loeblichi (Miller \& Furnish, 1940)
4 specimens (UMNH IP 3116-3119)

1 specimen (UMNH IP 3230)

29 specimens (UMNH IP 3150-3178)

1 specimen (UMNH IP 3200)

1 specimen (UMNH IP 3292)

6 specimens (UMNH IP 3997-4002)

16 specimens (UMNH IP 3120-3126-3191-3199)

1 specimen (UMNH IP 3294)

6 specimens (UMNH IP 4003-4009)

1 specimen (UMNH IP 4061)

2 specimens (UMNH IP 4100-4101)

11 specimens (UMNH IP 2643-2653)

14 specimens (UMNH IP 2663-2676)

14 specimens (UMNH IP 2688-2690-2707-2717)

22 specimens (UMNH IP 2724-2727-2738-2795-2811)

22 specimens (UMNH IP 2812-2833)

2 specimens (UMNH IP 3231-3232)

6 specimens (UMNH IP 3284-3289)

10 specimens (UMNH IP 3295-3304)

28 specimens (UMNH IP 3475-3487-3801-3815)

1 specimen (UMNH IP 2641)

7 specimens (UMNH IP 2682-2687-2691)

2 specimens (UMNH IP 3241-3242)

1 specimen (UMNH IP 3307)

17 specimens (UMNH IP 3473-3474-3532-3546)

1 specimen (UMNH IP 2642)

1 specimen (UMNH IP 2677)

1 specimen (UMNH IP 3272)

2 specimens (UMNH IP 3798-3799)

1 specimen (UMNH IP 2654)

4 specimens (UMNH IP 2973-2976)

6 specimens (UMNH IP 3526-3531)

15 specimens (UMNH IP 3101-3115)

3 specimens (UMNH IP 3234-3236)

1 specimen (UMNH IP 3308)

5 specimens (UMNH IP 4088-4092)

4 specimens (UMNH IP 3933-3936)

2 specimens (UMNH IP 4062-4063)

1 specimen (UMNH IP 4095) 
Jensen Wash; bed 28 (sample 97UTMI-15)

Girtyoceras sp.

Goniatites deceptus sp. nov.

Jensen Wash; bed 28 (sample 93UTMI-27)

Girtyoceras sp.

Goniatites deceptus sp. nov.

Praedaraelites loeblichi (Miller \& Furnish, 1940)

Jensen Wash; bed 28 (sample 04UTMI-1)

Goniatites deceptus sp. nov.

Goniatites sp.

Material in the Museum für Naturkunde Berlin (Korn coll.):

Duckwater Hills (2007)

Goniatites deceptus sp. nov.

Hamilton Canyon; bed 44 (2007)

Girtyoceras hamiltonense sp. nov.

Kazakhoceras bylundi sp. nov.

Goniatites eganensis sp. nov.

Goniatites sowerbyi sp. nov.

Praedaraelites loeblichi (Miller \& Furnish, 1940)

Cathedral Canyon (2007)

Goniatites deceptus sp. nov.

Rosebud Spring (2007)

Goniatites americanus Gordon, 1971

Granite Mountain South; bed 17 (2005)

Goniatites americanus Gordon, 1971

Granite Mountain South; bed 17 (2007)

Calygirtyoceras arcticum (Gordon, 1957)

Dimorphoceratidae sp. indet.

Kazakhoceras bylundi sp. nov.

Granite Mountain South; bed 25 (2005)

Goniatites americanus Gordon, 1971

Praedaraelites loeblichi (Miller \& Furnish, 1940)

Granite Mountain South; bed 25 (2007)

Calygirtyoceras arcticum (Gordon, 1957)

Girtyoceras primum sp. nov.

Goniatites americanus Gordon, 1971

Granite Mountain North; bed 33 (2005)

Goniatites deceptus sp. nov.

Granite Mountain North; bed 35 (2007)

Goniatites deceptus sp. nov.

Foote Range (2010)

Goniatites deceptus sp. nov.
15 specimens (UMNH IP 3202-3216)

6 specimens (UMNH IP 3824-3829)

13 specimens (UMNH IP 3201-3217-3228)

9 specimens (UMNH IP 3937-3944-3996)

1 specimen (UMNH IP 4102)

7 specimens (UMNH IP 3838-3844)

10 specimens (UMNH IP 4078-4087)

36 specimens (MB.C.12028.1-MB.C.12028.36)

16 specimens (MB.C.12005.1-MB.C.12005.16)

1 specimen (MB.C.12012)

7 specimens (MB.C.12030.1-MB.C.12030.7)

4 specimens (MB.C.12032.1-MB.C.12032.4)

4 specimens (MB.C.12034.1-MB.C.12034.4)

16 specimens (MB.C.12027.1-MB.C.12027.16)

6 specimens (MB.C.12020.1-MB.C.12020.6)

9 specimens (MB.C.12013.1-MB.C.12013.8-MB.C.12024)

2 specimens (MB.C.12002.1-MB.C.120022)

1 specimen (MB.C.12009)

1 specimen (MB.C.12011)

59 specimens (MB.C.12014.1-MB.C.12014.59)

1 specimen (MB.C.12033)

15 specimens (MB.C.12003.1-MB.C.12003.15)

66 specimens (MB.C.12004.1-MB.C.12004.66)

259 specimens (MB.C.12025.1-MB.C.12025.259)

16 specimens (MB.C.12026.1-MB.C.12026.16)

21 specimens (MB.C.12029.1-MB.C.12029.21)

3 specimens (MB.C.12039.1-MB.C.12039.3) 
Middle Confusion Range 1; bed 6 (2005)

Entogonites borealis Gordon, 1957

Calygirtyoceras confusionense Gordon, 1957

Dimorphoceras rileyi sp. nov.

Goniatites americanus Gordon, 1971

Middle Confusion Range 1; bed 8 (2005)

Goniatites americanus Gordon, 1971

Middle Confusion Range 1; bed 8 (2007)

Goniatites americanus Gordon, 1971

Middle Confusion Range 1; bed 12 (2005)

Goniatites americanus Gordon, 1971

Middle Confusion Range 1; bed 12 (2007)

Goniatites americanus Gordon, 1971

Middle Confusion Range 2; bed 9 (2005)

Calygirtyoceras confusionense Gordon, 1957

Dimorphoceras rileyi sp. nov.

Goniatites americanus Gordon, 1971

Middle Confusion Range 3; bed 10 (2005)

Goniatites americanus Gordon, 1971

Conger Mountain East; bed 14 (2010)

Entogonites acus sp. nov.

Goniatites americanus Gordon, 1971

Conger Mountain East; bed 20 (2010)

Girtyoceras hamiltonense sp. nov.

Goniatites sowerbyi sp. nov.

South Burbank Hills; bed 8 (2007)

Bollandoceras sp.

Goniatites americanus Gordon, 1971

South Burbank Hills; bed 26 (2007)

Girtyoceras hamiltonense sp. nov.

Metadimorphoceras richardsi sp. nov.

Goniatites eganensis sp. nov.
1 specimen (MB.C.11999)

1 specimen (MB.C.12000)

3 specimens (MB.C.12007.1-MB.C.12005.3)

5 specimens (MB.C.12015.1-MB.C.12015.5)

13 specimens (MB.C.12016.1-MB.C.12016.13)

5 specimens (MB.C.12021.1-MB.C.12021.5)

6 specimens (MB.C.12017.1-MB.C.12017.6)

12 specimens (MB.C.12022.1-MB.C.12022.12)

2 specimens (MB.C.12001.1-MB.C.12001.2)

1 specimen (MB.C.12008)

5 specimens (MB.C.12018.1-MB.C.12018.5)

7 specimens (MB.C.12019.1-MB.C.12019.7)

1 specimen (MB.C.12035)

5 specimens (MB.C.12036.1-MB.C.12036.5)

2 specimens (MB.C.12037.1. MB.C.12037.2)

2 specimens (MB.C.12038.1. MB.C.12038.2)

2 specimens (MB.C.11998.1-MB.C.11998.2)

2 specimens (MB.C.12023.1-MB.C.12023.2)

10 specimens (MB.C.12006.1-MB.C.12005.10)

4 specimens (MB.C.12010.1-MB.C.12010.4)

4 specimens (MB.C.12031.1-MB.C.12031.4) 